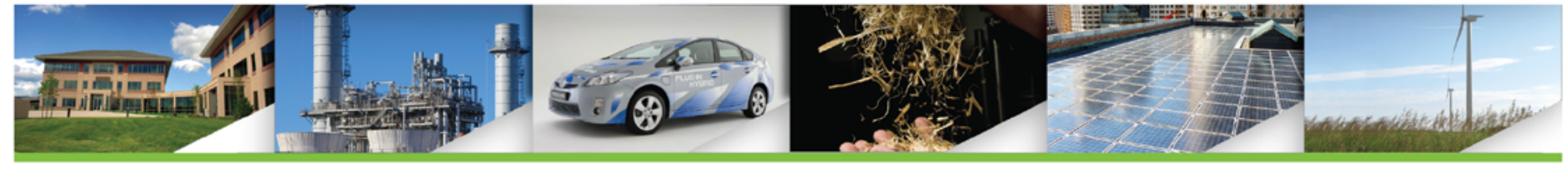

\title{
Options for Resilient and Flexible Power Systems in Select South American Economies
}

Josue Campos do Prado, Jeffrey Logan, and Francisco Flores-Espino

National Renewable Energy Laboratory (NREL)

Technical Report

NREL/TP-6A50-75431

December 2019

Contract No. DE-AC36-08G028308 


\section{Options for Resilient and Flexible Power Systems in Select South American Economies}

Josue Campos do Prado, Jeffrey Logan, and Francisco Flores-Espino

National Renewable Energy Laboratory (NREL)

The Joint Institute for Strategic Energy Analysis 15013 Denver West Parkway Golden, CO 80401 303-275-3000 • www.jisea.org
The Joint Institute for Strategic Energy Analysis is operated by the Alliance for Sustainable Energy, LLC, on behalf of the U.S. Department of Energy's National Renewable Energy Laboratory, the University of Colorado-Boulder, the Colorado School of Mines, the Colorado State University, the Massachusetts Institute of Technology, and Stanford University.

JISEA $^{\circledR}$ and all JISEA-based marks are trademarks or registered trademarks of the Alliance for Sustainable Energy, LLC.

Technical Report

NREL/TP-6A50-75431

December 2019

Contract No. DE-AC36-08GO28308 


\section{NOTICE}

This work was authored by the National Renewable Energy Laboratory, operated by Alliance for Sustainable Energy, LLC, for the U.S. Department of Energy (DOE) under Contract No. DE-AC36-08G028308. Funding provided by the U.S. Department of Energy's Office of International Affairs. The views expressed herein do not necessarily represent the views of the DOE or the U.S. Government.

This report is available at no cost from the National Renewable Energy Laboratory (NREL) at www.nrel.gov/publications.

U.S. Department of Energy (DOE) reports produced after 1991 and a growing number of pre-1991 documents are available free via www.OSTI.gov.

Cover Photos: (left to right) NREL 04135, iStock 22779761, NREL 16933., NREL 15648, NREL 08466, NREL 21205

NREL prints on paper that contains recycled content. 


\section{Acknowledgments}

The authors would like to thank Elena Berger and Sheila Moynihan from the Office of International Affairs at the U.S. Department of Energy. They provided guidance, support and vision throughout the process of conducting the research and writing this document. Sandra Dickison from the same office also provided assistance in planning dissemination of the results.

We also thank Abigail Rockwell and Lily M. Bravo (U.S. Embassy Santiago), and Derek Wong, Urfa Qadri, and Viviana Weismann (U.S. Embassy Buenos Aires) for their assistance in providing relevant data and information for this report, and planning and arranging meetings with key stakeholders in Chile and Argentina.

The authors are grateful for the relevant inputs and data received from Carlos Toro Ortiz and Jerson Reyes Sánchez (Chilean Ministry of Energy); Ernesto Huber and Juan Carlos Araneda (Chilean National Electricity Coordinator); Ernesto Anadón and Martín Kaindl (IAPG); Leonardo Mastronardi, Luciano Caratori, Guillermo Koutoudjian, and Oscar Natale (Argentina Energy Secretariat); Joaquín Mahdjoubian Díaz Cano (YPF); Giovani Machado, Renato Haddad Simões Machado, Thiago Ivanoski Teixeira, and Maria Cecilia Pereira de Araújo (Brazil EPE); Bernardo Bezerra, Luiz Augusto Barroso, and Ricardo Cunha Perez (PSR); Victor Raposo (Petrobras); Javier Martínez Gil and Antonio Jimenez (UPME); and José Manuel Moreno (Colombian Ministry of Mines and Energy). These acknowledgements recognize assistance and insights in providing background information for production of this report, but the individuals mentioned did not all provide feedback on draft versions of this document and do not necessarily agree with or support the findings.

For their feedback on draft versions of this document, we thank Andrea Watson, Omar Jose Guerra Fernandez, Sherry Stout, and Jill Engel-Cox from NREL. We also thank Tim Coburn from the University of Tulsa, and the Renewable and Sustainable Energy Institute (RASEI) at the University of Colorado in Boulder. Ivonne Pena-Cabra from Key Logic provided feedback on various sections of the report. Carlos Toro Ortiz and Benjamin Maluenda (Chilean Ministry of Energy) reviewed sections related to Chile. Renato Haddad Simões Machado, Thiago Ivanoski Teixeira, and Maria Cecilia Pereira de Araújo (Brazil EPE) reviewed sections related to Brazil. Fernando Rodriguez (U.S. DOE Office of International Affairs) and Ookie Ma (U.S. DOE Office of Energy Efficiency and Renewable Energy) offered timely feedback and recommendations. Any remaining errors or oversights are the responsibility of the authors. 


\section{List of Acronyms}

21CPP

ANEEL

BNEF

CAMMESA

COP

CREG

CSP

DER

DG

DOE

EIA

ENSO

EPE

FLNG

FSRU

GIZ

IDB

IAPG

IEA

IRENA

ISA

LNG

LPG

NCRE

NOAA

OECD

ONI

PPA

PRONUREE

SACZ

SASH

SEC

TPES

UPME

VRE

WRI

YPF $21^{\text {st }}$ Century Power Partnership (a Clean Energy Ministerial Initiative)

Agência Nacional de Energia Elétrica (Brazilian Electricity Regulatory

Agency)

Bloomberg New Energy Finance

Compañía Administradora del Mercado Mayorista Eléctrico (Argentinian

Wholesale Electricity Market Administrator)

Colombian Peso

Comisión de Regulación de Energía y Gas (Colombian Energy and Gas

Regulatory Commission)

Concentrated solar power

Distributed energy resource

Distributed generation

U.S. Department of Energy

U.S. Energy Information Administration

El Niño Southern Oscillation

Empresa de Pesquisa Energética (Brazilian Energy Research Office)

Floating liquified natural gas

Floating storage and regasification unit

Gesellschaft für Internationale Zusammenarbeit (German International

Cooperation Corporation

Inter-American Development Bank

Instituto Argentino del Petroleo y del Gas (Argentinian Institute of Oil and Gas)

International Energy Agency

International Renewable Energy Agency

Interconexiones Eléctricas S.A. (Colombian transmission company)

Liquefied natural gas

Liquefied petroleum gas

Non-conventional renewable energy

National Oceanographic and Atmospheric Administration

Organization for Economic Co-operation and Development

Oceanic Niño Index

Power purchase agreement

Programa Nacional de Uso Racional y Eficiente de la Energía (Brazilian

Program for the Rational and Efficient Use of Energy)

South Atlantic Convergence Zone

South Atlantic Subtropical High

Securities and Exchange Commission

Total primary energy supply

Unidad de Planeación Minero Energética (Colombian Energy and Mining

Planning Unit)

Variable renewable energy

World Resources Institute

Yacimientos Petrolíferos Fiscales (Argentinian energy company) 


\section{Executive Summary}

\section{Introduction}

Power systems around the globe are changing rapidly due to a confluence of technological, social, meteorological and business drivers. Wind and solar, especially paired with competitive auction procurement, have become the lowest cost new generation options in many regions of the world. In several countries, the emergence of plentiful and affordable shale gas is leading to the retirement of older incumbent generators, and greater liquidity and flexibility in liquified natural gas (LNG) markets. Battery storage, demand response, electric vehicle charging and other distributed energy resources (DERs) are altering the way power systems are planned and operated. Few locales, if any, will be immune to these dynamics.

These changes are highlighting the need for flexibility and resilience in energy systems. This is seen clearly in select South American countries that have traditionally relied heavily on large (dammed) hydropower stations and who now also see increasingly rapid growth in variable renewable energy (VRE) sources. Over the past decade, some of these countries have experienced dramatic changes in hydropower availability due to variations in precipitation associated with "El Niño" and "La Niña" hydrological phases. In Brazil, for example, hydropower plants typically provided $80 \%$ of annual power generation needs before 2010 , but in the El Niño years of 2014-2015, its contribution fell to $64 \%$. Similar situations exist in Colombia and to a much lesser extent in Argentina and Chile.

This document summarizes opportunities for select representative countries in South America to adapt to these buffeting forces to ensure reliable, affordable, sustainable and resilient power systems. Special attention is placed on the potential role for natural gas to help ensure flexible and resilient power. Argentina, Brazil, Chile and Colombia are all vying to play stronger leadership roles in the continent, and all have stated increasingly bold commitments to sustainable development.

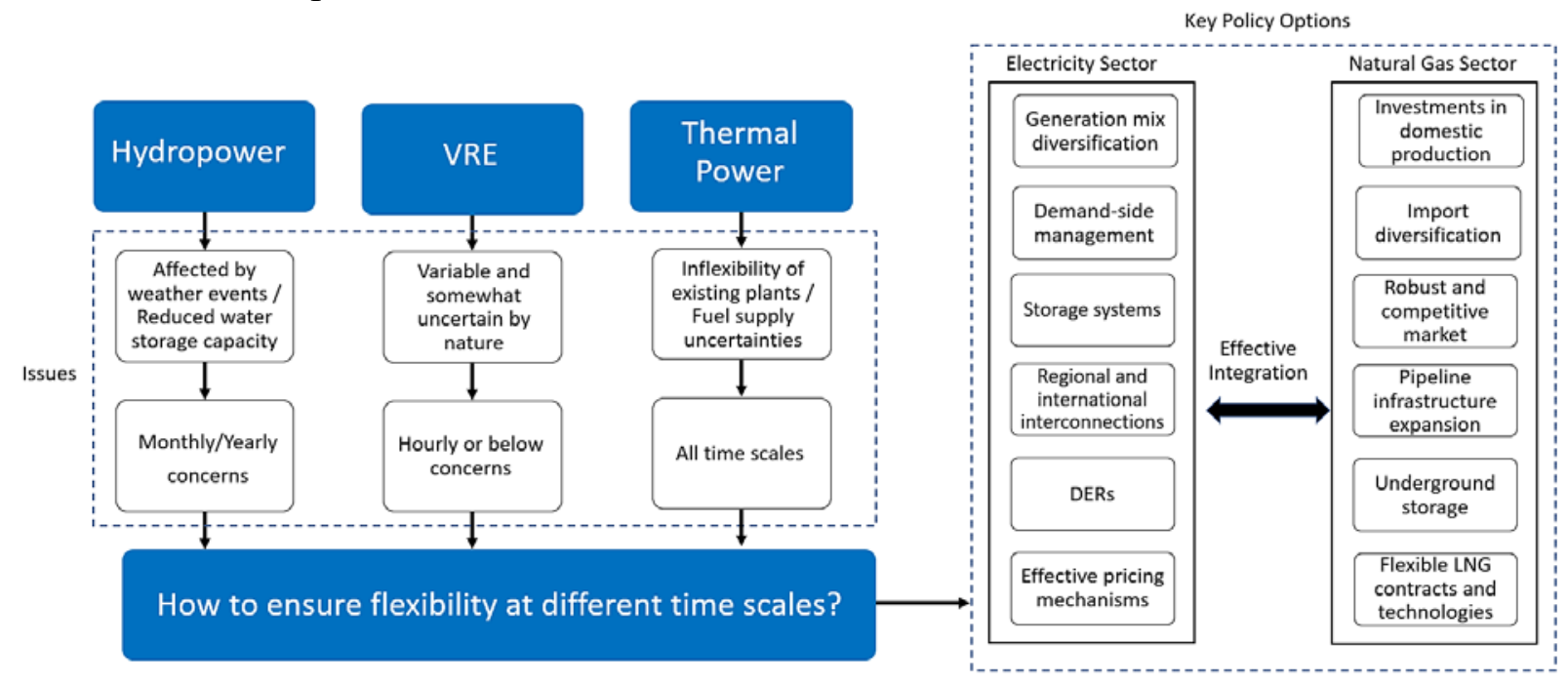

Figure ES-1. Flexibility issues and options in power systems of key South American countries 
Figure ES-1 summarizes the approach taken in this study to consider options in both electricity and natural gas sectors for providing flexibility and resiliency over different time scales. The analysis considers flexibility and resiliency needs at a high level but does not weigh specific cost-benefit investment opportunities.

Table ES-1 compares and contrasts risks and constraints associated with the need for greater flexibility in the power sectors of all four countries. Brazil and Colombia are most exposed to threats from El Niño and La Niña impacts on hydropower output. Brazil and Chile are experiencing the fastest growth in VRE deployment. Currently, Argentina is most exposed to risk from fuel-supply uncertainty due to its relatively high reliance on natural gas generation, although Brazil, Chile and Colombia are not immune to these risks. All countries except Brazil face significant challenges in extracting greater flexibility from their existing thermal fleet of generators. Argentina probably has the best chance of continuing to build large hydropower plants, but even there, public opposition to that choice is still relatively high.

Table ES-1. Risks and Constraints for More Flexible Power Generation in Select South American Countries

\begin{tabular}{|c|l|c|c|c|c|}
\cline { 3 - 5 } \multicolumn{1}{c|}{} & Argentina & Brazil & Chile & Colombia \\
\hline \multirow{4}{*}{$\begin{array}{c}\text { Flexibility } \\
\text { Catalysts }\end{array}$} & Weather events affecting hydropower & Medium & High & Medium & High \\
\cline { 2 - 5 } & $\begin{array}{l}\text { Increasing adoption of run-of-the-river } \\
\text { power plants }\end{array}$ & Medium & High & Medium-High & High \\
\cline { 2 - 6 } & Increasing VRE integration & Medium & High & High & Low \\
\cline { 2 - 6 } & Thermal power generation inflexibility & High & Low & High & High \\
\cline { 2 - 6 } & Fuel-supply uncertainties & High & Medium & Medium & Medium \\
\hline
\end{tabular}

Table ES-2 summarizes some of the key barriers and challenges to further development of the electricity and natural gas sectors in the four countries targeted in this study. Relative to the others, Argentina faces challenges because of its aging infrastructure (exemplified by a blackout in June of 2019) and from directing sufficient revenue for investment in both electricity and gas - a situation that is primarily due to its prolonged economic instabilities (high inflation rates and currency fluctuation) and market distortions associated with subsidies. All four countries face limitations associated with transmission capacity, public opposition to large hydropower plants and market mechanisms to promote greater flexibility in the electricity sector. In the gas sector, all four countries face limitations in underground storage and pipeline capacity. Chile is relatively unique in being the only country with insufficient domestic gas reserves, while Brazil faces techno-economic challenges associated with developing its offshore resources. 
Table ES-2. Barriers and Challenges for Electricity and Natural Gas Development in Select South American Countries

\begin{tabular}{|c|c|c|c|c|c|}
\hline & Critical Issue & Argentina & Brazil & Chile & Colombia \\
\hline \multirow{7}{*}{$\begin{array}{l}\text { Relative } \\
\text { barriers } \\
\text { and } \\
\text { challenges } \\
\text { in the } \\
\text { electricity } \\
\text { sector }\end{array}$} & Aging infrastructure & $x$ & & & \\
\hline & Transmission capacity limitations & $x$ & $x$ & $x$ & $x$ \\
\hline & Insufficient revenue for investment & $x$ & & & \\
\hline & Public opposition to large hydropower plants & $x$ & $x$ & $x$ & $x$ \\
\hline & Limited international interconnections & & & $\mathrm{x}$ & $\mathrm{x}$ \\
\hline & $\begin{array}{l}\text { Lack of market mechanisms to promote greater } \\
\text { flexibility }\end{array}$ & $x$ & $x$ & $x$ & $x$ \\
\hline & Demand concentration in specific regions & $x$ & & $x$ & \\
\hline \multirow{5}{*}{$\begin{array}{l}\text { Relative } \\
\text { barriers } \\
\text { and } \\
\text { challenges } \\
\text { in the } \\
\text { natural } \\
\text { gas sector }\end{array}$} & $\begin{array}{l}\text { Techno-economic challenges associated with } \\
\text { domestic production }\end{array}$ & & $x$ & & \\
\hline & Insufficient long-term domestic gas reserves & & & $x$ & \\
\hline & Lack of underground storage infrastructure & $\mathrm{x}$ & $\mathrm{x}$ & $\mathrm{x}$ & $\mathrm{x}$ \\
\hline & Pipeline capacity limitations & $\mathrm{x}$ & $x$ & $x$ & $x$ \\
\hline & Insufficient revenue for investment & $\mathrm{x}$ & & & \\
\hline
\end{tabular}

\section{Country-specific Options}

\section{Argentina}

The Argentinian energy sector currently faces strong headwinds due to the shrinking economy, high inflation, and the depreciating peso. Nonetheless, Argentina has very ambitious plans to develop natural gas fields in the Vaca Muerta formation and build infrastructure to move gas to market. This play has the potential to not only supply Argentina's domestic needs but couldunder the right conditions - allow Argentina to export gas by pipeline to Chile, Brazil, and potentially other countries, and to ship it in the form of LNG around the globe. Development of the resource, and the infrastructure needed to move the gas considerable distances, is challenged by the current economic difficulties, regulatory risks, and decades of market distortions that impact the flow of investments. While the Macri government (2015-2019) took steps to reduce these distortions, economic uncertainty remains, and new political developments could reverse decisions made over the past few years. Addressing remaining market distortions so that investment will flow to where it is most needed is a key challenge for Argentinian policymakers, although this is a difficult task in a period of economic crisis.

Adding more natural gas pipelines and underground storage appears to be a high priority for the country given the seasonal imbalances in the market.

The Argentinian power system is dominated by natural gas and hydropower generation (Figure ES-2). Over the past few years, it has taken successful steps to accelerate the deployment of renewables through its auction programs. Continued focus on deploying VRE can be a source of low-cost electricity that offsets the need for gas- or oil-fired generation, although siting and constructing new transmission lines remains a challenge. Demand-side energy efficiency activities may be one of the least costly ways for Argentina to support reliable electricity services, especially given the demand growth that occurred during the peak years of previous 
energy subsidies. Coordinated planning of energy infrastructure build-out using state-of-the-art modeling tools may be an option for Argentinian decision-makers to prioritize.
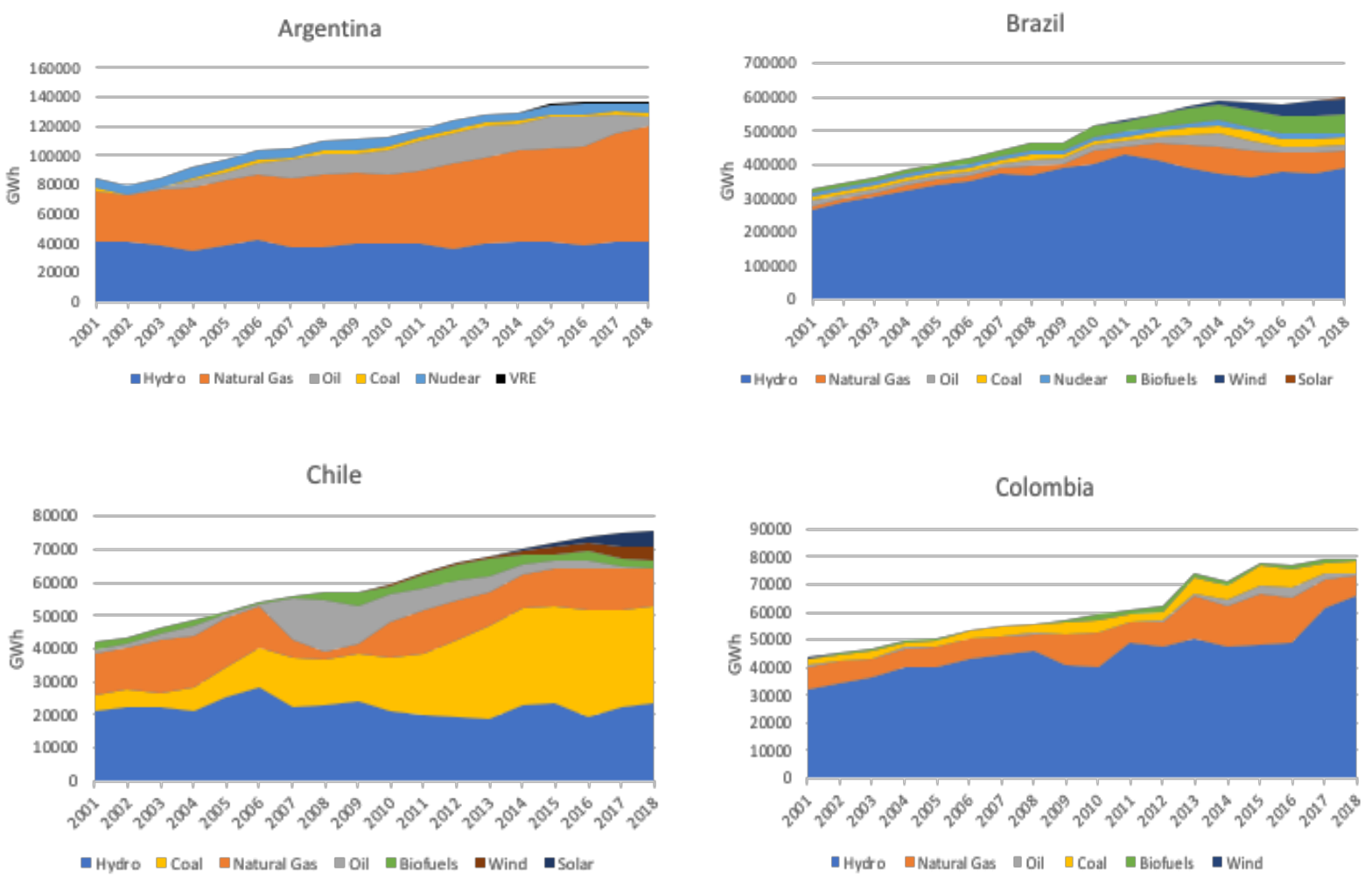

Figure ES-2. Evolving generation mixes in Argentina, Brazil, Chile, and Colombia, 2001-2018

\section{Brazil}

Brazil's power sector continues to be dominated by hydropower, although its share of total generation has been in decline since roughly 2011. Brazil has sophisticated energy planning capabilities and has installed more nonhydro renewables than any other South American country over the past decade. It is working to integrate more VRE and demand-response capabilities into the grid, and reforming electricity pricing mechanisms to better reflect supply and demand over shorter time intervals. It may also benefit from greater interconnection of transmission lines with neighboring countries and greater integration of distributed energy resources (DERs). Figure ES2 illustrates how Brazil's generation mix has evolved over the past decade.

Brazil is working to develop its considerable offshore natural gas resources, and like Argentina, would benefit from more gas infrastructure, especially large-scale underground storage. It has taken advantage of floating storage and regasification units (FSRUs) to import LNG during periods of peak demand without having to commit to permanent land-based infrastructure. This reliance on FSRUs is expected to grow over the coming years, at least until obtaining more certainty over development prospects for offshore resources. Brazil is also taking steps to introduce more competition within the natural gas sector and reduce the dominance of Petrobras over production, transmission, and distribution. 


\section{Chile}

Chile has been at the global forefront in introducing market-oriented liberalization and privatization of its energy sector. Chile faced a gas crisis starting in 2004 (when Argentina abruptly reduced pipeline exports) that had profound impacts on the country. The immediate response was to briefly rely on other petroleum products in electricity generation to make up for the lost gas supply and to construct several LNG import terminals. Coal generation also grew rapidly over the past decade as a longer-term substitute for natural gas, but the government announced in mid-2019 that it would phase out coal generation by 2040 . Figure ES- 2 reflects these changes.

Chile has also seen rapid growth in VRE since 2014 and has extremely high-quality solar resources in the north and wind in the south. Planning and constructing transmission capacity to move the power to the demand centers in and around Santiago (and to mining load centers in the northern regions for night-time operations) remains a top priority for Chilean decision-makers. The share of electricity coming from hydropower plants with large reservoirs has fallen rapidly as the country moved to greater reliance on run-of-the-river configurations, which are not capable of providing medium- and long-term flexibility services.

Chile is likely to rely more heavily on imported natural gas in the near term given the shrinking availability of hydropower and the planned phase-out of coal. It has plans to build new LNG import infrastructure and recently began to import gas again from Argentina via pipeline. Greater interconnection of electricity lines with neighboring countries, use of demand response, and deployment of a variety of energy storage options are three other opportunities for Chile to improve flexibility and resilience in the power sector.

\section{Colombia}

Like much of Brazil, Colombia is heavily dependent on large hydropower and is exposed to drought conditions during El Niño years. Colombia is a major exporter of coal, yet that fuel supplies only about $10 \%$ of the country's electricity generation mix, slightly less than the level of natural gas generation (Figure ES-2). The country's natural gas production is in fairly rapid decline, while demand continues to grow, leading Colombia to begin importing LNG in 2016 using FSRUs. LNG imports are expected to grow rapidly in the near future. A pipeline connects Venezuela and Colombia, but no trade occurs despite the former having the largest gas reserves in South America. Both countries use the majority of their natural gas for reinjection at oil production sites to increase formation pressure. Also, like Brazil, Colombia has recently discovered significant offshore gas reserves, but analysts do not expect growth in production for a least a decade when drilling and infrastructure build-out can be completed.

Colombia has a partially liberalized electricity sector but still provides subsidies to non-lowincome consumers. It is beginning to rectify the distortions that these subsidies can cause. Colombia is the only country analyzed here that does not yet have a developed market for VRE deployment, although the country's first successful VRE auction in late 2019 is likely to change the situation. Colombia is targeting over 2,000 MW of new renewables to be deployed by the end of 2020. 


\section{Conclusion}

Argentina, Brazil, Chile, and Colombia face unique challenges in building out their electricity sectors to achieve resilient, reliable and sustainable systems. Each country faces challenges from uncertain hydropower output due to variable interannual weather conditions, but Argentina is less exposed to these variations. All have goals to rapidly boost domestic VRE generation, and all except Chile have significant natural gas resources that they plan to aggressively develop. Argentina's Vaca Muerta formation may be the biggest uncertainty in South America's evolving electric power sector calculus: this promising resource base could have far-reaching regional, and even global, repercussions on energy markets, yet the country faces significant economic and political challenges in developing it. In the meantime, imported LNG may be the most expedient option for Brazil, Chile, and Colombia on the margins given the recently improved liquidity of, and contract terms for, that fuel.

While technology and market innovations in the form of rapidly falling costs for VRE, LNG contracting, battery storage, and other distributed energy options can sometimes outpace the institutional and policy capacity to effectively guide them, other breakthroughs could occur to better harmonize the deployment of flexibility and resiliency options. These South American countries face significant challenges in meeting future electricity sector aspirations, but the speed of change is occurring so rapidly that unexpected developments should be considered likely. On a positive note, each of these countries is building from a strong base of renewable hydropower toward a diverse portfolio of solar, wind, and gas, targeting clean and resilient power systems. 


\section{Table of Contents}

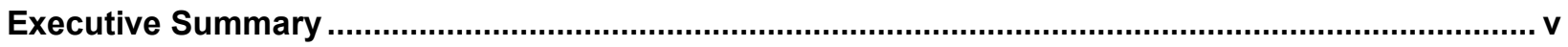

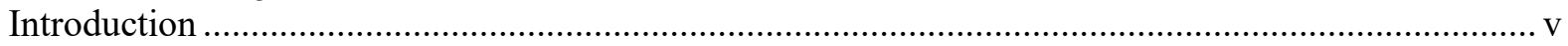

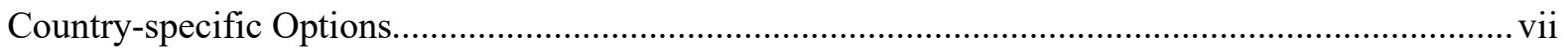

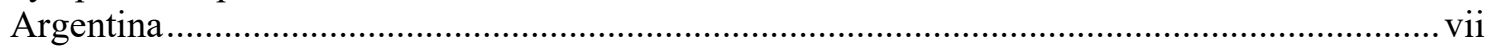

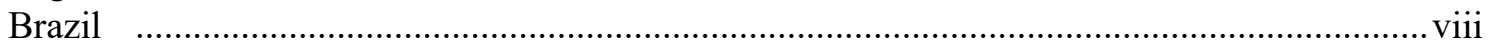

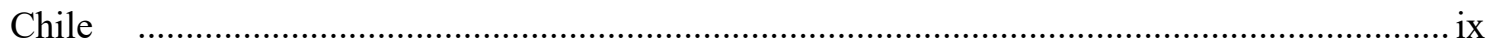

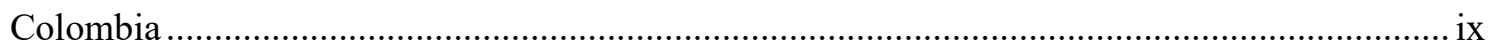

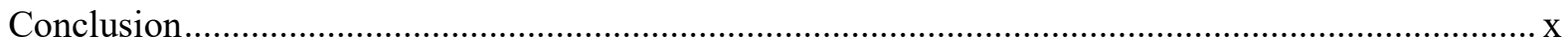

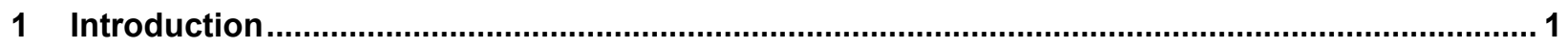

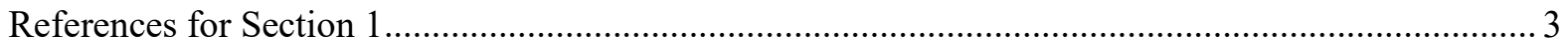

2 Power System Transformation: Increasing Need for Resiliency and Flexibility in Select South

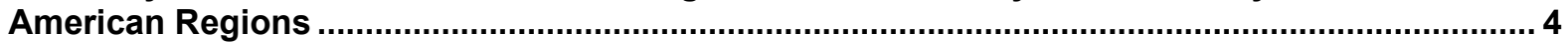

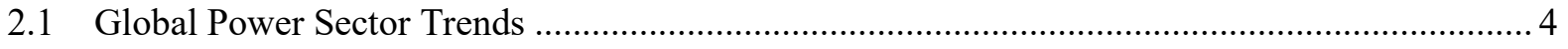

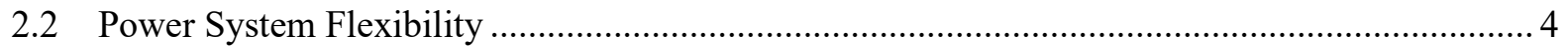

2.3 The Shifting Electricity Landscape in Select South American Countries.................................. 6

2.4 Main Drivers of the Need for Power System Flexibility....................................................... 7

2.4.1 Socio-environmental issues associated with hydropower and the increasing adoption of

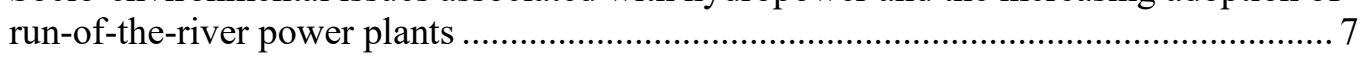

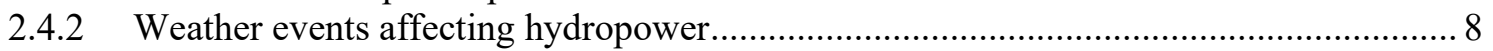

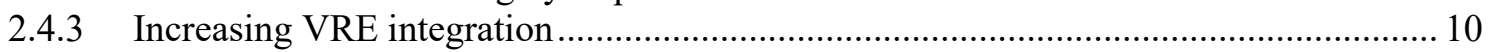

2.4.4 Thermal power inflexibility and fuel supply uncertainties.......................................... 11

2.5 Natural Gas as an Increasingly Important Generation Option in South America ...................... 11

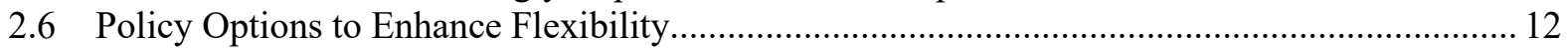

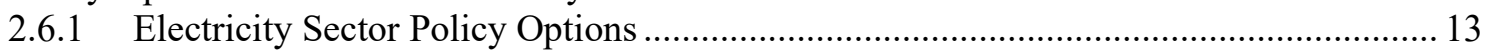

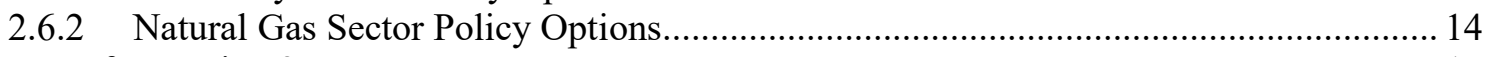

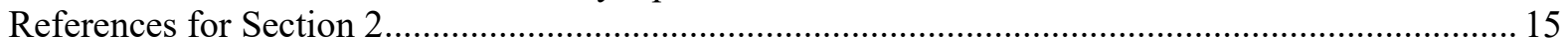

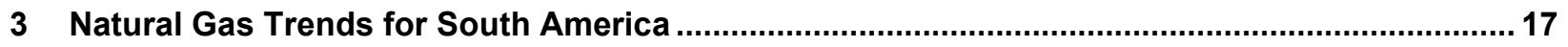

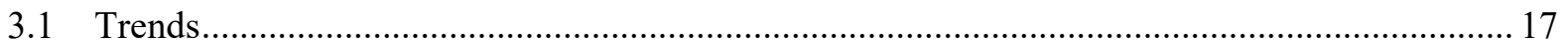

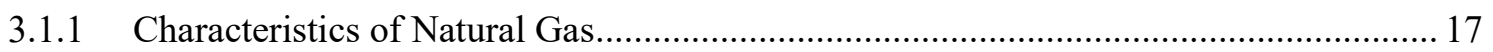

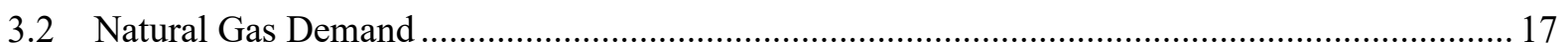

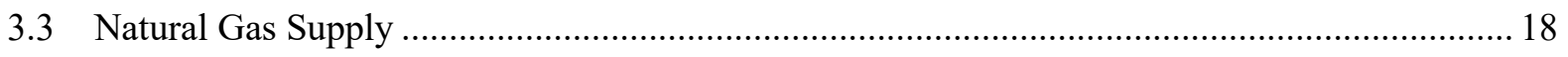

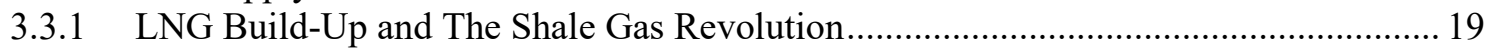

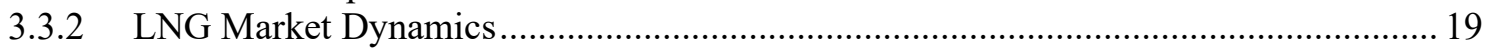

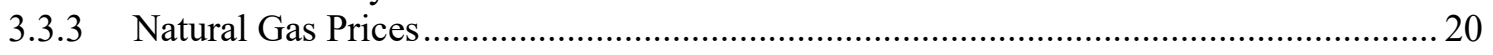

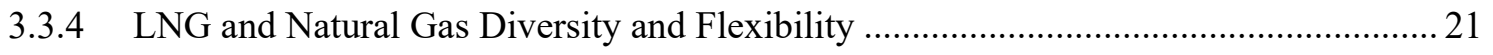

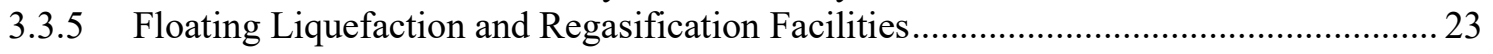

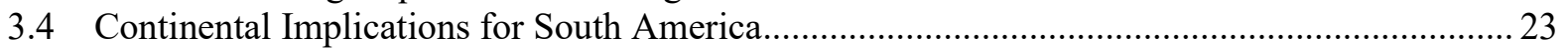

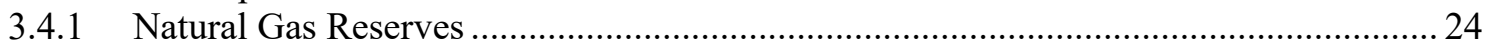

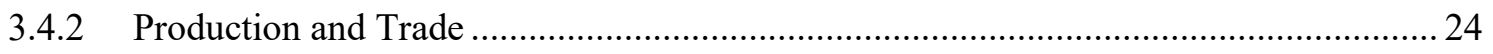

3.4.3 Regional Drivers to Increase Natural Gas Infrastructure ......................................... 25

3.4.4 Liquefied Natural Gas Imports to South America.................................................... 25

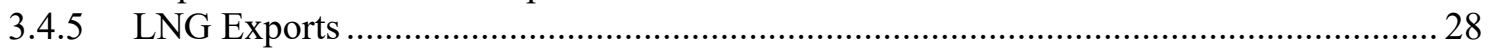

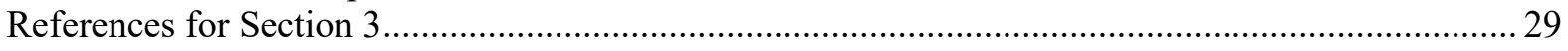

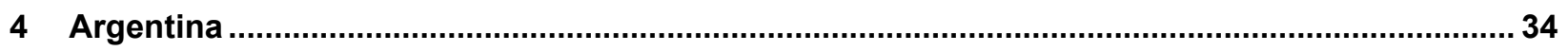

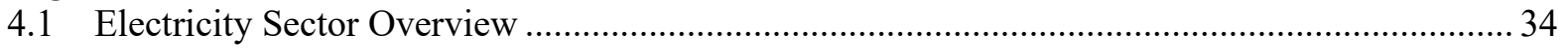

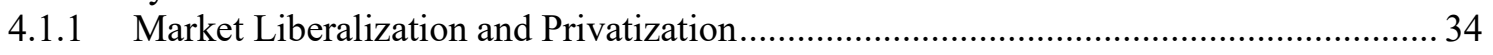

4.1.2 The 2001-2002 Crisis and Electricity Subsidy Policies ............................................. 34

4.1.3 Efforts to Increase Generation Capacity and Flexibility until 2015 ............................. 35

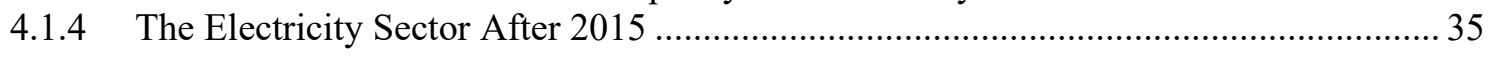




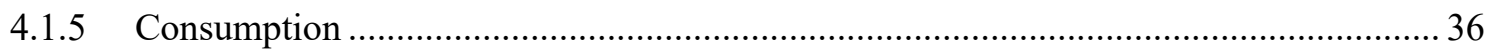

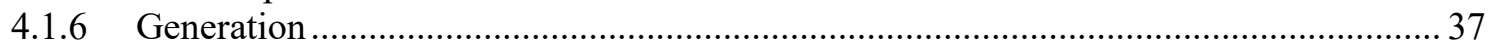

4.1.7 Transmission Infrastructure.............................................................................. 41

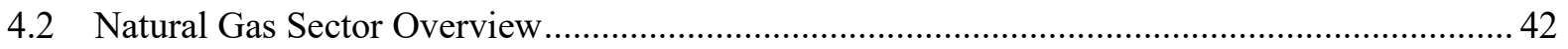

4.2.1 Liberalization and Privatization Policies in the early 1990's ...................................... 42

4.2.2 The 2004 Gas Crisis .............................................................................................. 42

4.2.3 Efforts to Increase Domestic Natural Production Until 2015 ........................................ 43

4.2.4 The Natural Gas Sector After 2015 ………………........................................... 43

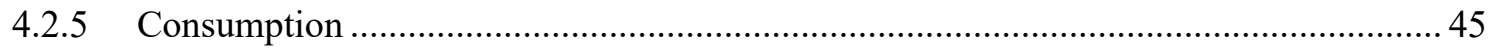

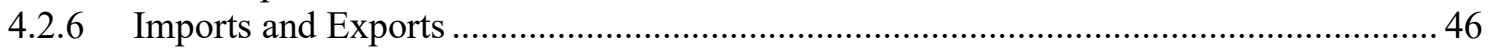

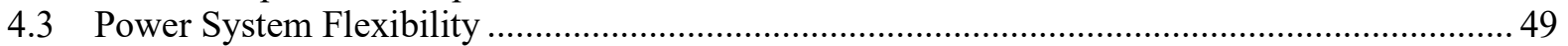

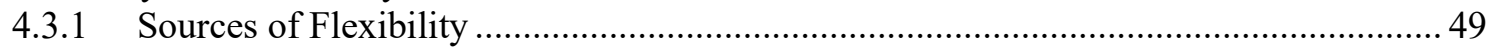

4.3.2 Drivers of the Need for Flexibility ……………………......................................... 49

4.4 Key Policy Options to Enhance Flexibility in Argentina ......................................................... 51

4.4.1 Electricity Sector Policy Options ……………………………………………………. 51

4.4.2 Natural Gas Sector Policy Options.............................................................................. 52

References for Section 4............................................................................................................. 54

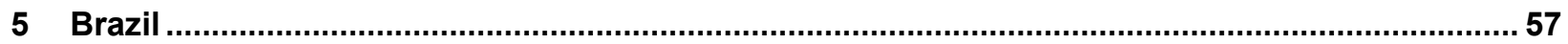

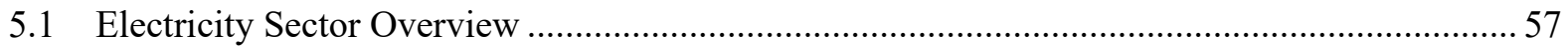

5.1.1 Brief History and Sector Organization....................................................................... 57

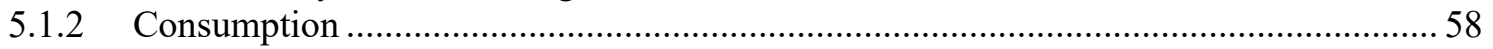

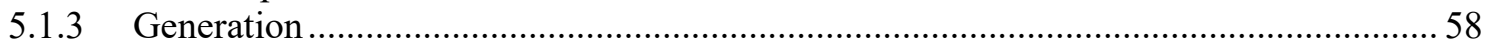

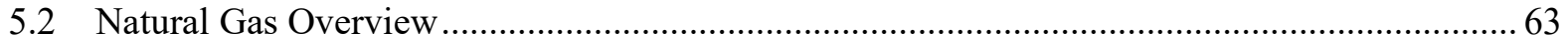

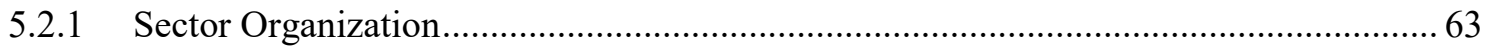

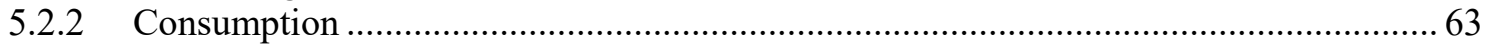

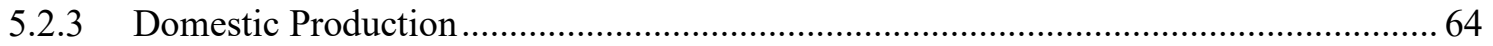

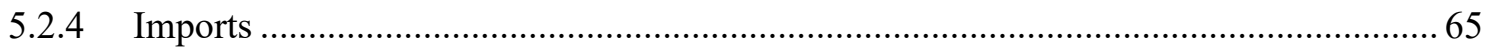

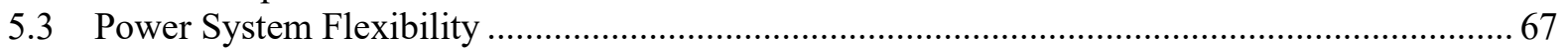

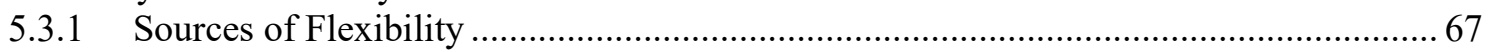

5.3.2 Drivers of the Need for Flexibility ……………………………………………...... 69

5.4 Key Policy Options to Enhance Flexibility in Brazil ........................................................... 70

5.4.1 Electricity Sector Policy Options ………………………………………………..... 70

5.4.2 Natural Gas Sector Policy Options............................................................................ 72

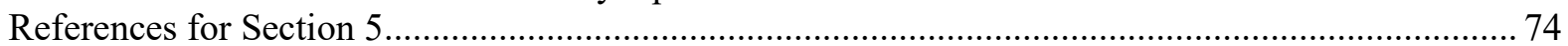

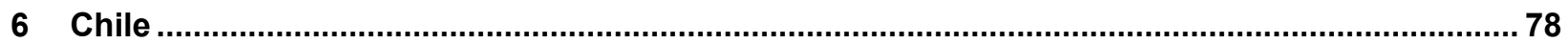

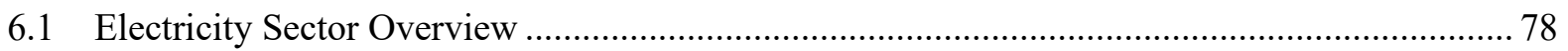

6.1.1 Market Liberalization and Privatization.................................................................... 78

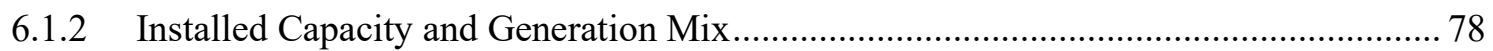

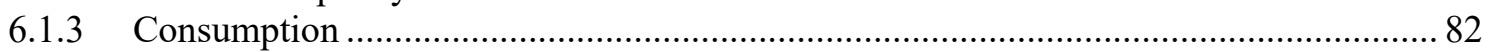

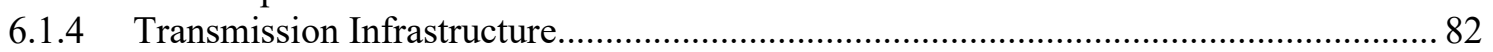

6.2 Natural Gas Sector Overview..................................................................................... 82

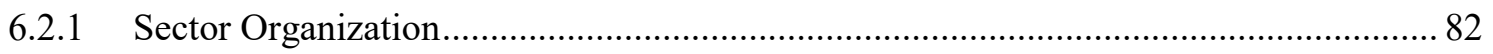

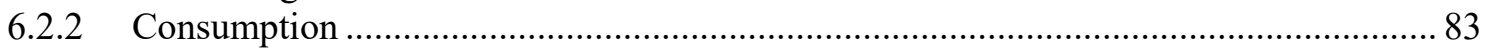

6.2.3 Domestic Production and Imports.............................................................................. 83

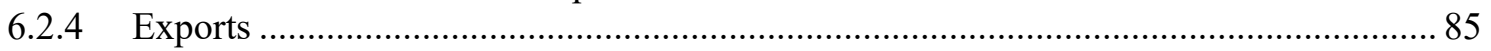

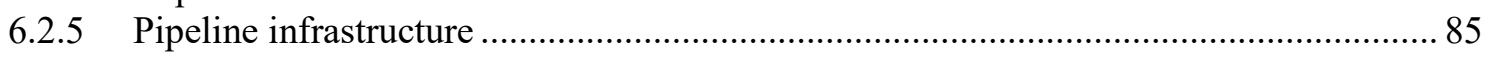

6.3 Power System Flexibility ……………………………………………………………… 85

6.3.1 Sources of Flexibility …………………………………………………….... 85

6.3.2 Drivers of the Need for Flexibility …………………………………………….. 85

6.4 Key Policy Options to Enhance Flexibility in Chile ………………………………………..... 87

6.4.1 Electricity Sector Policy Options ……………………………………………….... 88 


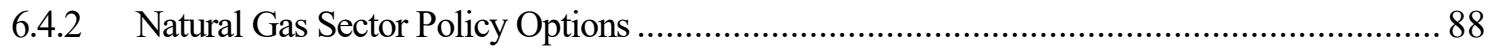

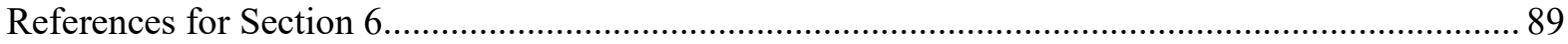

7 Colombia

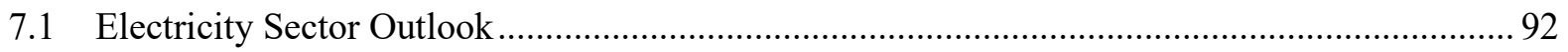

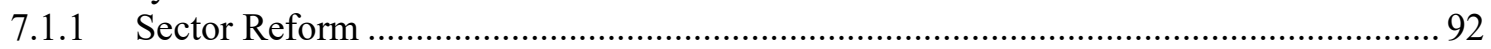

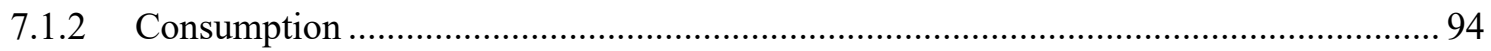

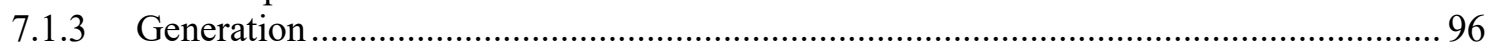

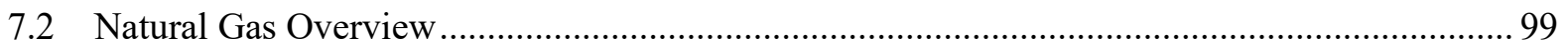

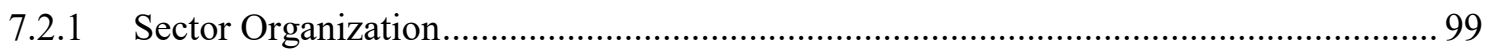

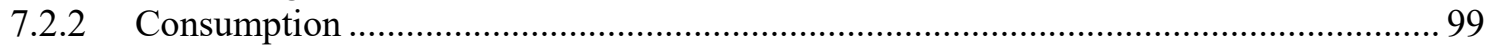

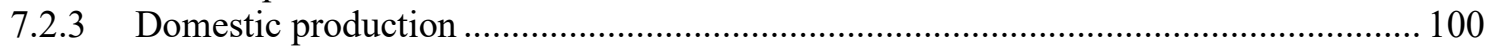

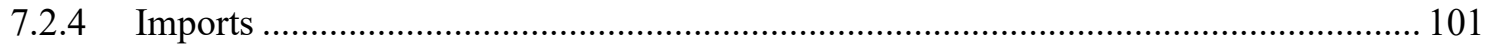

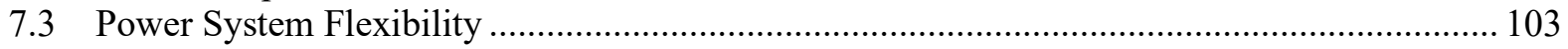

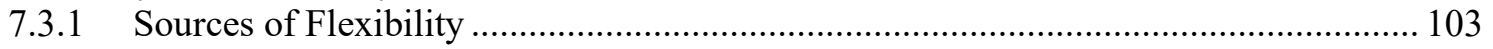

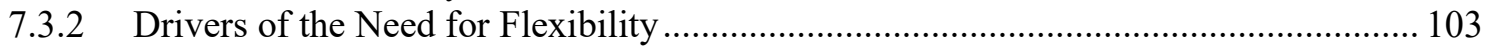

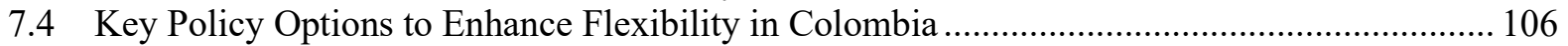

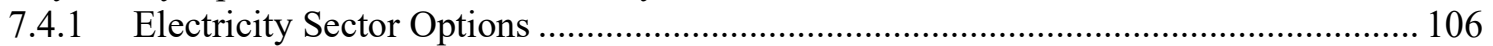

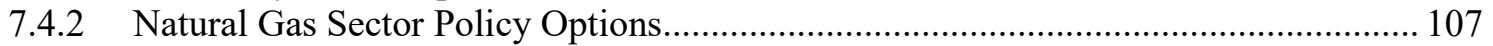

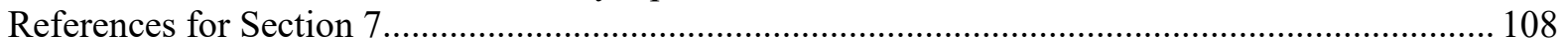

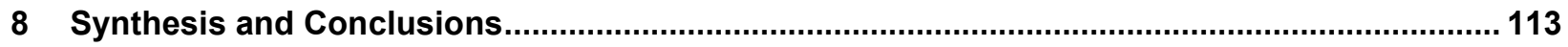

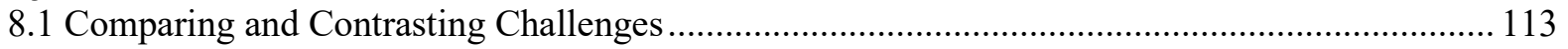

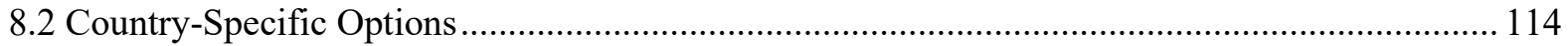

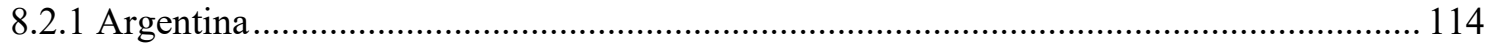

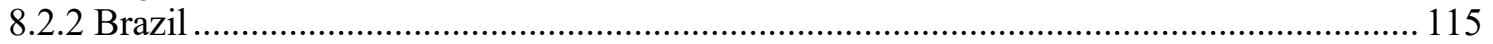

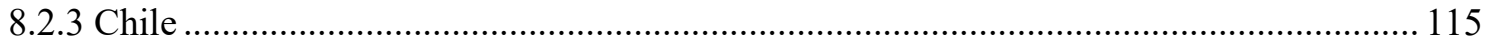

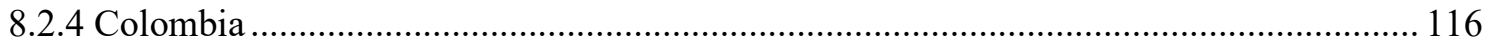

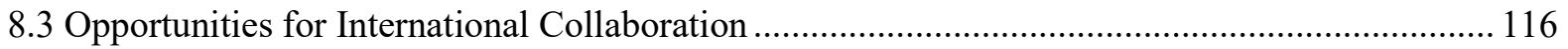

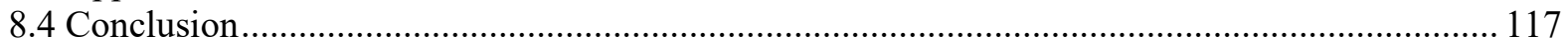

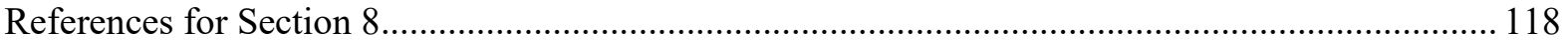




\section{List of Figures}

Figure ES-1. Flexibility issues and options in power systems of key South American countries ................ v

Figure ES-2. Evolving generation mixes in Argentina, Brazil, Chile, and Colombia, 2001-2018 ............viii

Figure 1. Key drivers of global power system transformation........................................................ 4

Figure 2. Key components of power system flexibility .................................................................... 5

Figure 3. Aggregated installed capacity in Argentina, Brazil, Chile, and Colombia .................................. 7

Figure 4. Active daily hydroelectric capacity in Colombia ............................................................. 9

Figure 5. Average water storage capacity in the Brazilian Southeast/Central-West subsystem................ 10

Figure 6. Aggregated VRE installed capacity in Argentina, Brazil, and Chile........................................ 11

Figure 7. Aggregated natural gas consumption in Argentina, Brazil, Chile, and Colombia...................... 12

Figure 8. Flexibility issues and options in power systems of key South American countries .................... 13

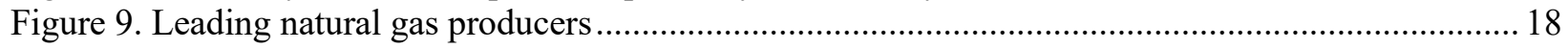

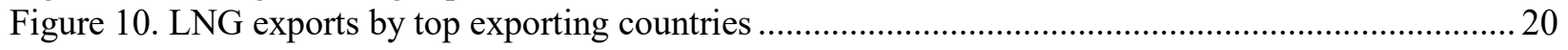

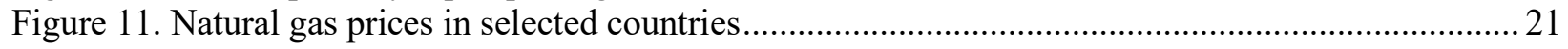

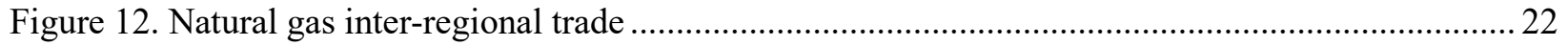

Figure 13. Major natural gas trade movements in 2018................................................................. 23

Figure 14. LNG imports in selected countries of South America and total for South America and Central

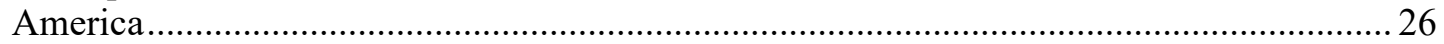

Figure 15. Average residential electricity prices in South American countries........................................ 35

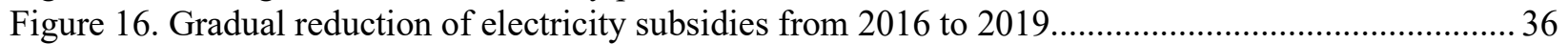

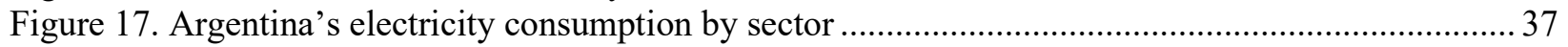

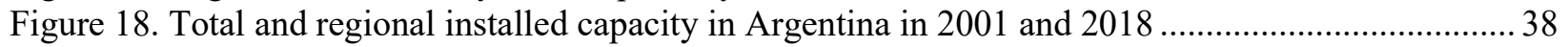

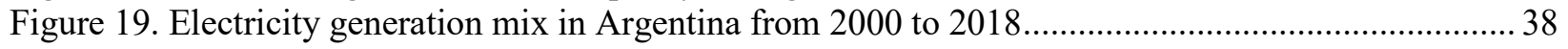

Figure 20. Share of Argentina's thermal power generation by fuel ......................................................... 39

Figure 21. RenovAr (Rounds 1.0, 1.5, and 2) awarded bidders by country of origin.............................. 41

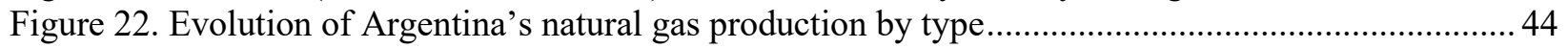

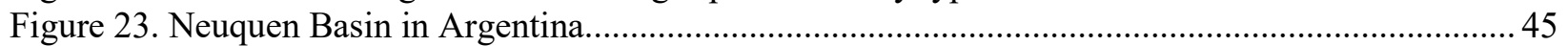

Figure 24. Monthly natural gas production and consumption in Argentina ........................................ 46

Figure 25. Natural gas consumption by sector from 2008 to 2018 in Argentina ..................................... 46

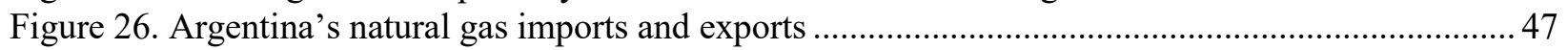

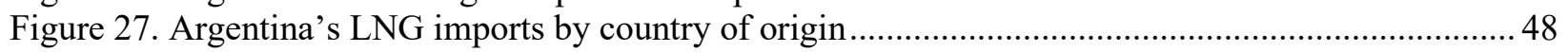

Figure 28. Hydropower generation of Salto Grande Dam in Argentina ................................................. 49

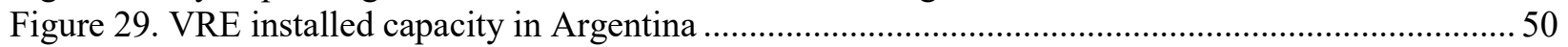

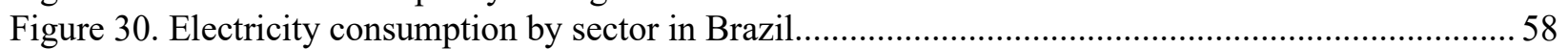

Figure 31. Total and regional installed capacity in Brazil in 2008 and 2018 ......................................... 59

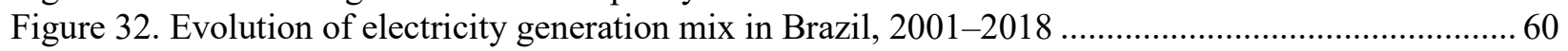

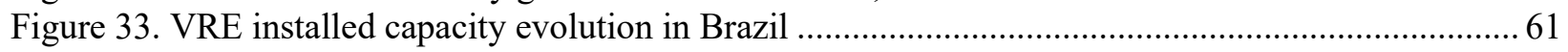

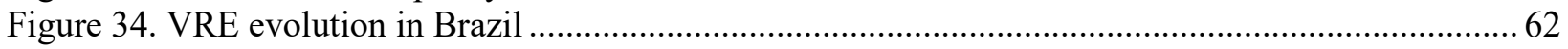

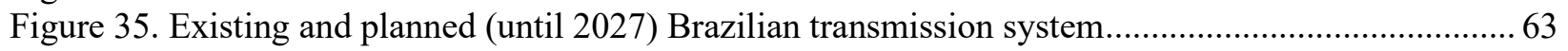

Figure 36. Natural gas consumption in Brazil by sector versus net production....................................... 64

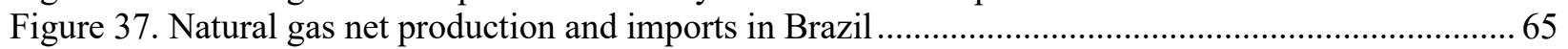

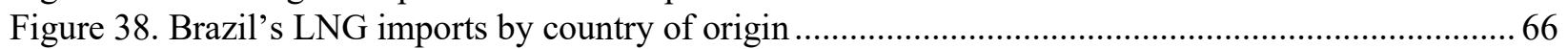

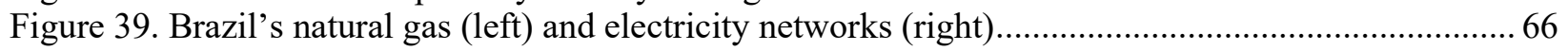

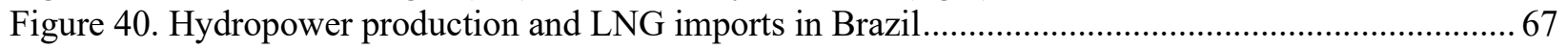

Figure 41. Spot electricity price and thermal generation in the Northeast region of Brazil ...................... 68

Figure 42. Water storage capacity in two distinct wet periods in Brazil's South region ............................ 69

Figure 43. Water storage capacity in two distinct wet periods in Brazil's Northeast region..................... 70

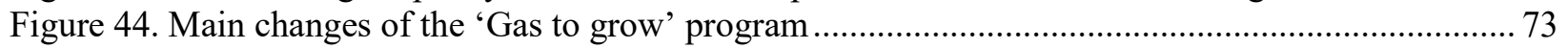

Figure 45. Total and regional installed capacity in Chile in 2008 and 2018....................................... 78

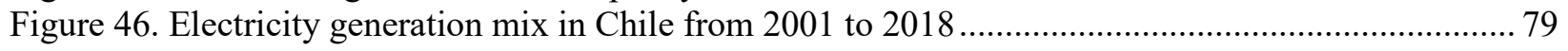


Figure 47. VRE installed capacity in Chile from 2010 to July 2019 ................................................... 81

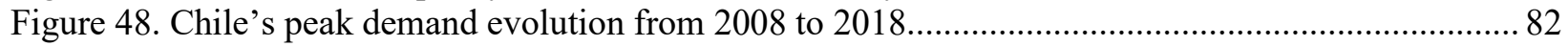

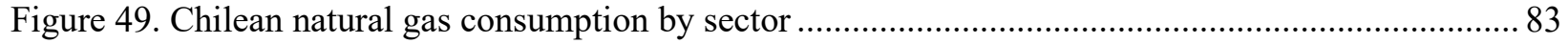

Figure 50. Chilean natural gas production, pipeline imports, and LNG imports ...................................... 84

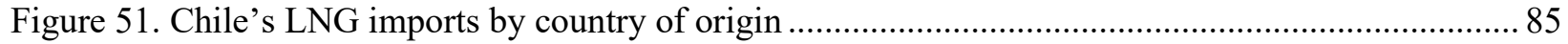

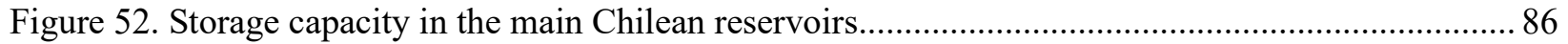

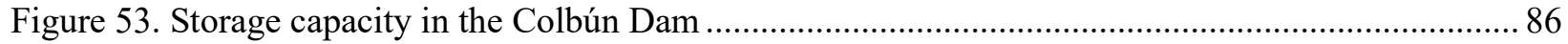

Figure 54. Subsidies and contributions paid to and by electricity customers in Colombia 2012-2018 .... 94

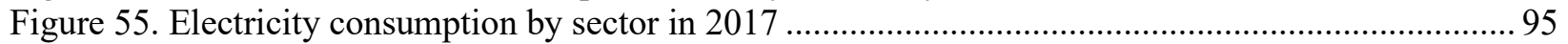

Figure 56. Colombia's domestic electricity demand projection, 2018-2029 ….................................. 95

Figure 57. Total and regional installed capacity for Colombia, 2012 and 2019 ................................. 96

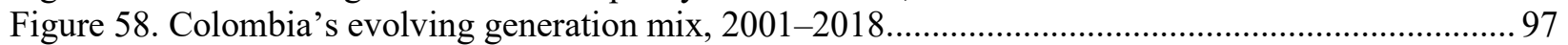

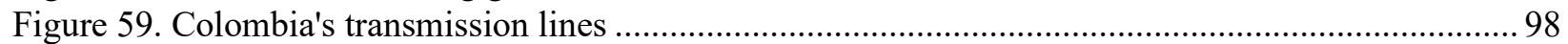

Figure 60. Main sectors for the final consumption of natural gas in Colombia..................................... 100

Figure 61. Colombia's natural gas pipelines and offshore licenses.................................................. 102

Figure 62. Impoundment volume monthly average as a percentage of total volume capacity ................. 104

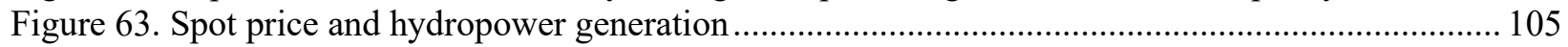

\section{List of Tables}

Table ES-1. Risks and Constraints for More Flexible Power Generation in Select South American Countries

Table ES-2. Barriers and Challenges for Electricity and Natural Gas Development in Select South

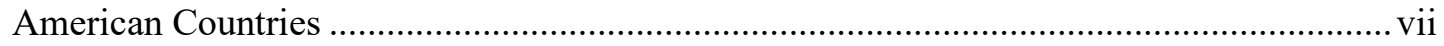

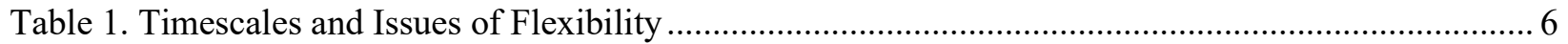

Table 2. Oceanic Niño Index in 2011 (La Niña), 2014, and 2015 (El Niño) ......................................... 8

Table 3. Proven and Unproven Technically Recoverable Natural Gas Reserves in Selected Countries of

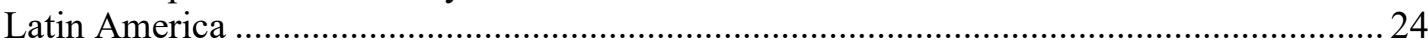

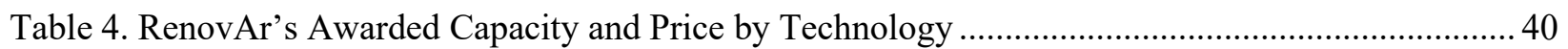

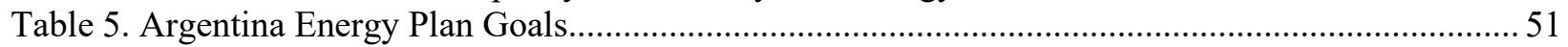

Table 6. Contracting Environments in the Brazilian Electricity Market................................................. 57

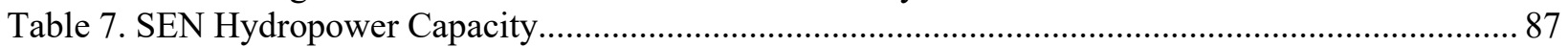

Table 8. Transaction Types Allowed in the Wholesale Energy Market in Colombia................................ 92

Table 9. Colombian Production and Imports by Year, 2006-2017 (million cubic feet)......................... 101

Table 10. Risks and Constraints for More Flexible Power Generation in Select South American Countries

Table 11. Barriers and Challenges for Electricity and Natural Gas Development in Select South American Countries 


\section{Introduction}

Power systems around the globe are changing rapidly due to a confluence of technological, social, climate and politico-economic drivers (21CPP and IEA 2019, BNEF 2019, IEA 2018, DNV GL 2019). Wind and solar, especially paired with competitive auction procurement, have become the cheapest new generation options in many regions of the world. In several countries, the emergence of plentiful and affordable shale gas is leading to the retirement of incumbent generators, and greater liquidity and flexibility in liquified natural gas (LNG) markets. Battery storage, demand response, electric vehicle charging and other changes at the distribution grid edge are altering the way power systems are planned and operated. Few locales, if any, will be immune from these dynamics.

These changes are highlighting the need for flexibility and resilience in energy systems. This is seen clearly in select South American countries that have traditionally relied heavily on large hydropower stations and who now also see rapid growth in variable renewable energy (VRE) sources. Over the past decade, some of these countries have seen dramatic changes in hydropower availability due to variations in precipitation associated with "El Niño" and "La Niña" climate phases. In Brazil, for example, hydropower plants typically provided $80 \%$ of annual power generation needs before 2010, but in El Niño years of 2014-2015, its contribution fell to 64\% (EPE 2019a). Similar situations exist in Colombia and to a much lesser extent in Argentina and Chile, although the Chilean power sector has also faced chronic drought conditions over the past 5-10 years. At the same time, all four countries have either fostered strong growth in VRE or are starting to do so.

This research report explores opportunities for select countries in South America to adopt to these buffeting forces to ensure flexible, reliable, affordable, sustainable and resilient power systems. Special attention is placed on the potential role for natural gas to help ensure flexible and resilient power. Argentina, Brazil, Chile and Colombia are all vying to play stronger leadership roles in the continent, and all have stated increasingly strong commitments to sustainable development strategies.

Section 2 of this report summarizes key trends in power systems around the world and highlights special characteristics of these changes in the South American context. As new technologies (solar, wind and batteries), business models (corporate purchasing of renewables, auctions, aggregated demand response) and social desires (sustainability, individual control of energy choices, cyber-secure systems) penetrate electricity systems, the need for increased flexibility, resilience and reliability becomes increasingly clear. Policy and regulatory responses to these changes often lag behind. Section 2 creates a roadmap of electricity and natural gas policy options for each of the countries to consider.

Section 3 then presents a similar picture for the role of natural gas both globally and in South America. Natural gas still plays a relatively modest role for power generation in most of South America, although its use is growing rapidly in the four countries analyzed here. The availability of more flexible contracts to purchase LNG - shorter durations, smaller volumes, and greater availability in the spot market — combined with greater availability of offshore commercial infrastructure options such as floating LNG (FLNG) vessels having production, liquefaction, 
storage and transfer capabilities, and floating storage and regasification units (FSRU) as alternatives to onshore regasification, has added greater overall liquidity to LNG markets around the globe for both exporters and importers. Argentina, Brazil, Chile and Colombia have taken advantage of these developments, and will likely do so increasingly in the near- to mid-term future.

Sections 4-7 then provide case studies on the unique situations in Argentina, Brazil, Chile and Colombia, respectively. Argentina (Section 4) is in the midst of developing what is perhaps the most promising shale gas play in South America, Vaca Muerta, and what some have called the equivalent of the Eagle Ford Basin (Texas) for South America. The country is also facing tremendous economic challenges that will shape both the development of Vaca Muerta and the evolution of the larger energy economy.

Section 5 focuses on Brazil, the dominant economy of South America, and one that has relied extensively on large hydropower plants and sugar-cane-based ethanol for decades. In recent years, both wind and solar project development has also grown dramatically, as well as the development of offshore natural gas, and the importation of LNG. Like Argentina, but less severe, Brazil has also faced economic and political challenges in recent years.

In Section 6, the situation in Chile - a country that has been at the forefront of market-oriented electricity sector reforms - is highlighted. Chile has excellent solar resources in the northern part of the country and wind in the south but requires long transmission lines to connect the resources to demand centers in and around Santiago in the middle of the country. Chile has also vowed to retire a slew of coal plants built in the first decade of the new century when gas imports from Argentina were suddenly cut off due to crisis in the latter's economy.

Finally, Colombia is the focus of Section 7. Like Brazil, Colombia is highly dependent on hydropower although it faces severe drought conditions only during El Niño years rather than the combined El Niño and La Niña hydrological phenomenon in Brazil. Traditionally, Colombia also has large coal and natural gas output, but in recent years, net natural gas availability has declined, pushing Colombia to import growing quantities, mainly in the form of LNG. After several failed attempts to energize the renewable energy market-similar to the earlier situation in Argentina - Colombia appears ready to implement an aggressive plan to expand wind and solar, and perhaps other renewable generation sources.

Finally, Section 8 synthesizes and summarizes key findings from the study. A variety of tools and approaches can be used to address flexibility and resiliency needs in South American power markets. Conducting effective long-term planning exercises is essential to coordinate the elements of flexibility in a systematic fashion. Energy storage in different forms, natural gas, demand response and other distributed energy options may all have roles to play in ensuring resilient, affordable, and sustainable electricity systems that have high shares of hydropower and rapidly growing markets for variable renewable energy. 


\section{References for Section 1}

21CPP and International Energy Agency (IEA). 2019. "Status of Power System Transformation 2019: Power System Flexibility.” International Energy Agency. Paris.

https://www.21stcenturypower.org/assets/pdfs/status-of-power-system-transformation-2019.pdf

Bloomberg New Energy Finance (BNEF). 2019. "New Energy Outlook 2019.” Bloomberg. https://bnef.turtl.co/story/neo2019

DNV GL. 2019. “Energy Transition Outlook 2019.” DNV GL.

https://eto.dnvgl.com/2019/index.html

EPE (2019a), Balanço Energético Nacional. Accessed January 2019:

http://www.epe.gov.br/sites-pt/publicacoes-dados-abertos/publicacoes/PublicacoesArquivos/ publicacao-303/topico-419/BEN2018_ Int.pdf

International Energy Agency (IEA). 2018. “World Energy Outlook 2018.” IEA, Paris. 


\section{Power System Transformation: Increasing Need for Resiliency and Flexibility in Select South American Regions}

\subsection{Global Power Sector Trends}

Electricity sectors in a variety of countries are undergoing a period of rapid change as power systems move towards decarbonization, digitalization, and decentralization (Figure 1). This transformation has significantly changed the way power systems are designed, planned, and operated, thus creating new goals and challenges for energy security, affordability, reliability, resiliency, sustainability, and flexibility. Some key drivers behind these changes include increasing efforts to reduce greenhouse emissions, lower cost variable renewable energy (VRE) options, efficient and affordable energy storage systems, as well as innovative technologies that enable consumers to generate and store their own electricity, control their energy usage, interact with system operators, and provide services to the electricity grid in distributed or aggregated ways.

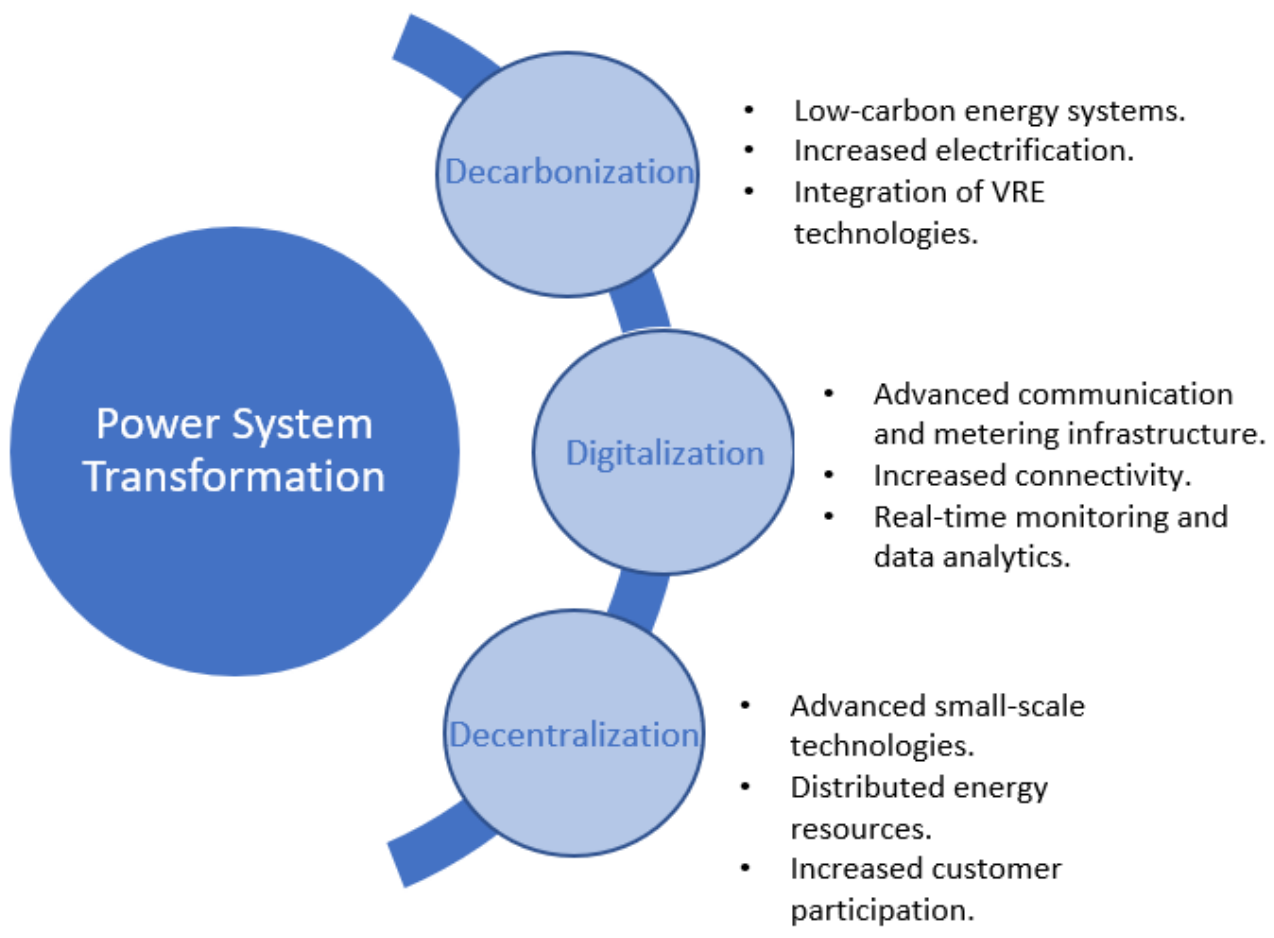

Figure 1. Key drivers of global power system transformation

\subsection{Power System Flexibility}

Power system flexibility has been receiving increasing attention as VRE and demand-side technologies are more widely adopted. This is not restricted to system performance in the shortterm, but also over medium- and long-term horizons. Various definitions of power system flexibility have been provided in the literature. For instance, Ela et al. (2018) define flexibility as 
"the ability of a resource, whether any component or collection of components of the power system, to respond to the known and unknown of power system conditions at various operational timescales". Milligan et al. (2015) divides power system flexibility into physical flexibility and institutional flexibility. The former refers to the physical operations of power systems while the latter is defined as "the ability to deploy the physical flexibility when needed and when it is available through operational practices and/or market design structures." In the same sense, power system flexibility can be divided into three layers: the institutional layer (comprising agents with clear roles and responsibilities), the layer of policy, regulatory, and market frameworks (defining technical rules and economic incentives), and the layer of hardware and infrastructure (defining the providers of physical flexibility) (IEA/21CPP 2018a).

A flexible power system should be able to withstand rapid intermittences, slow periodic fluctuations, and infrequent abrupt changes in both supply and demand sides in the most costeffective manner possible; otherwise the system may experience economic consequences as well as reliability and resiliency disturbances including voltage and frequency deviations, load curtailment, unnecessary VRE spillage, and price volatility. Flexibility needs to be harnessed in all parts of the power system and for all possible time horizons (IRENA 2018). Sources of flexibility can be centralized (large-scale generation units, grid interconnections, wholesale electricity market mechanisms, etc.) or distributed (small-scale generators, storage systems, and demand-response systems, retail market mechanisms, etc.).

Key components of power system flexibility include market efficiency, reliability, and resiliency, as described in Figure 2.

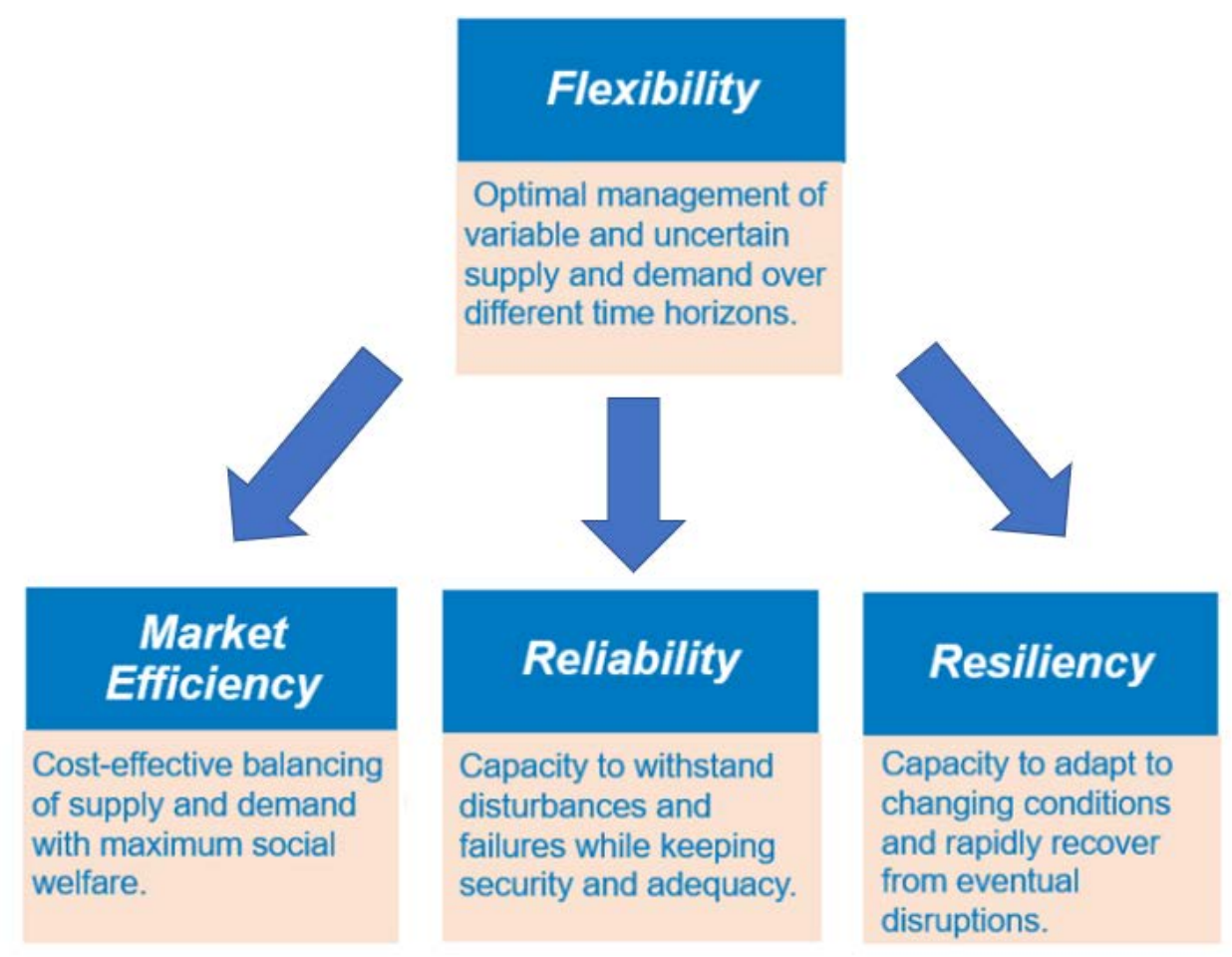

Figure 2. Key components of power system flexibility 
Flexibility needs to be considered in long-term electricity planning even in systems without an immediate flexibility deficit. This is because power systems change over time, as do their flexibility requirements.

The characteristics generally used to quantify the flexibility of a component or a collection of components in the power system are described below.

- Capacity: Range of available power (spinning/non-spinning) to be dispatched or load to be curtailed.

- Speed: Rate of incremental or decremental power generation/consumption change from generating units/loads.

- Duration: Amount of time that generation units or loads can maintain specific power levels.

Flexibility addresses different issues that span timescales that range from sub-seconds to years as illustrated in Table 1 (IEA/21CPP 2018a).

Table 1. Timescales and Issues of Flexibility

\begin{tabular}{|c|c|c|c|c|c|c|}
\hline Туре & \multicolumn{3}{|c|}{ Short-term } & $\begin{array}{c}\text { Medium- } \\
\text { term }\end{array}$ & \multicolumn{2}{|c|}{ Long-term } \\
\hline Timescale & $\begin{array}{l}\text { Subseconds } \\
\text { to seconds }\end{array}$ & $\begin{array}{l}\text { Seconds to } \\
\text { minutes }\end{array}$ & $\begin{array}{c}\text { Minutes to } \\
\text { hours }\end{array}$ & $\begin{array}{l}\text { Hours to } \\
\text { days }\end{array}$ & $\begin{array}{l}\text { Days to } \\
\text { months }\end{array}$ & $\begin{array}{c}\text { Months to } \\
\text { years }\end{array}$ \\
\hline $\begin{array}{l}\text { Issue to be } \\
\text { addressed }\end{array}$ & $\begin{array}{c}\text { System } \\
\text { stability (large } \\
\text { disturbances) }\end{array}$ & $\begin{array}{l}\text { Quick } \\
\text { fluctuations in } \\
\text { the balance of } \\
\text { supply and } \\
\text { demand }\end{array}$ & $\begin{array}{l}\text { Ramps in the } \\
\text { balance of } \\
\text { supply and } \\
\text { demand }\end{array}$ & $\begin{array}{l}\text { Decisions on } \\
\text { the number of } \\
\text { thermal } \\
\text { plants to } \\
\text { remain } \\
\text { running }\end{array}$ & $\begin{array}{c}\text { Schedule } \\
\text { maintenance } \\
\text { of power } \\
\text { plants / } \\
\text { Seasonal } \\
\text { availability of } \\
\text { some plants }\end{array}$ & $\begin{array}{c}\text { Seasonal and } \\
\text { inter-annual } \\
\text { balance of } \\
\text { generation } \\
\text { and demand }\end{array}$ \\
\hline
\end{tabular}

Source: Adapted from IEA/21CPP (2018a)

\subsection{The Shifting Electricity Landscape in Select South American Countries}

Select countries in South America are facing increasing risk and reliability concerns driven by high dependence on hydropower (and occasional/seasonal drought periods) and, increasingly, rapid growth of VRE sources. Countries including Argentina, Brazil, Chile, and Colombia are experiencing seasonal fluctuations in peak energy demand, increasing seasonal and annual fluctuations in hydropower supplies, and growth in variable solar and wind power, thereby increasing the need to expand emphasis on flexible energy sources. Figure 3 shows the aggregated electricity generation installed capacity in Argentina, Brazil, Chile, and Colombia in 2009 and 2019 (as of March), respectively. In the last ten years, the share of hydropower in total installed capacity decreased nearly 10 percentage points, mainly due to social opposition to large new hydropower plants, increased restrictions on environmental licenses, and new plans for energy diversification. On the other hand, the VRE installed capacity increased nearly 9 percentage points in the same period, mainly due to significant cost reductions of both wind and 
solar systems, governmental subsidies and incentives for VRE developments as well as high decarbonization goals.

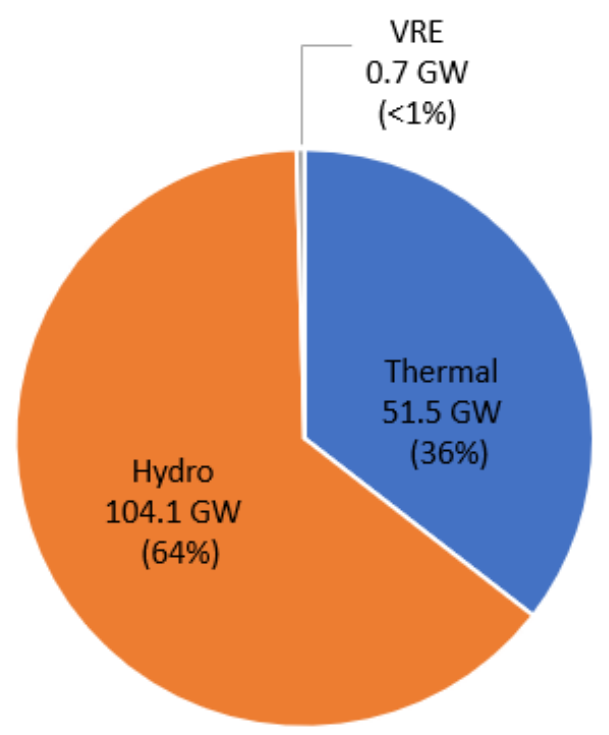

2009

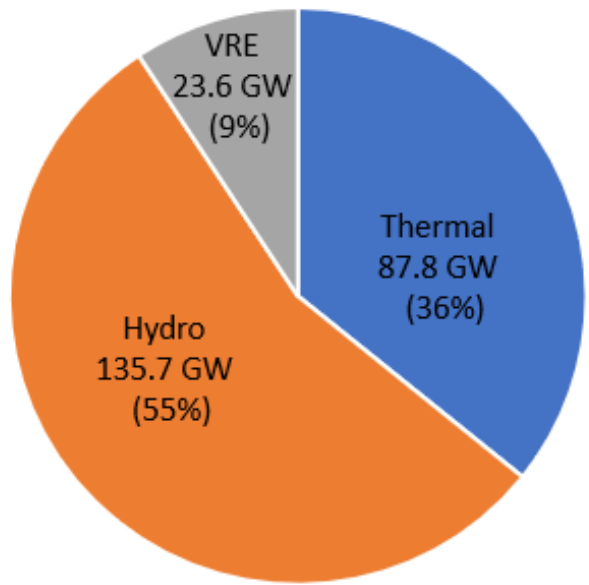

2019

Source: Data from Ministerio de Economía y Finanzas Públicas de Argentina (2009), Ministerio de Minas y Energía de Colombia (2010), Compañía Administradora del Mercado Mayorista Eléctrico (CAMMESA) (2019), Ministério de Minas e Energia (MME) (2019a), Comisión Nacional de Energía (CNE) (2019a), and XM Colombia (2019)

Figure 3. Aggregated installed capacity in Argentina, Brazil, Chile, and Colombia

\subsection{Main Drivers of the Need for Power System Flexibility}

\subsubsection{Socio-environmental issues associated with hydropower and the increasing adoption of run-of-the-river power plants}

Hydroelectricity has historically been the main source of load-following and flexibility reserve in many South American countries. Importantly, impoundment hydropower plants (those with large accumulation reservoirs such as the Tucuruí Power Plant in northern Brazil and the San Carlos Power Plant in northern Colombia) contribute to the stability of the power system and provide great flexibility by storing water to be released to generate power as needed. However, creating reservoirs for these power plants requires flooding of large areas of land, which entails significant socio-environmental impacts. On the other hand, diversion (also known as run-of-theriver) hydropower plants have become the most viable option in many countries - especially Brazil, Chile, and Colombia - due to their reduced social and environmental impacts, which makes it easier and faster to obtain all the required environmental licenses and construction permits. In Chile, for example, the share of impoundment hydropower plants in the country's hydropower installed capacity decreased from $64 \%$ in 2008 to only $32 \%$ in 2018 (CNE 2019b). Diversion power plants generate electricity by diverting a river's flow into a canal/penstock to generate power before returning the water to the river downstream. However, due to the lack of large reservoirs, their ability to provide flexibility is very limited during some seasons of the year. Despite having lower socio-environmental impacts compared to impoundment power plants, diversion power plant projects in critical regions still face public opposition issues. 


\subsubsection{Weather events affecting hydropower}

Argentina, Brazil, Chile, and Colombia are countries generally affected by seasonal weather phenomena that significantly impact hydropower production. The El Niño Southern Oscillation (ENSO), for example, is a natural phenomenon that changes trade winds and water temperatures in the tropical Pacific Ocean (TPO), causing changes in both temperature and rainfall in several countries. ENSO consists of a warm phase (El Niño), with TPO waters having temperatures above average, and the cold phase (La Niña), with TPO waters experiencing temperatures below average. The Oceanic Niño Index (ONI) is one of the main indices used to monitor ENSO phenomenon. The ONI is defined as the three-month moving average of sea surface temperature anomalies in the Niño-3.4 region, which is located in the east-central Pacific Ocean (NOAA 2019a).

The El Niño periods are known for causing severe droughts and presenting higher temperatures in northern South America, and plentiful rainfall in the southern part of the continent. The La Niña periods, however, present the opposite characteristics. El Niño periods have historically presented higher impacts on both rainfall and temperature variation than La Niña periods. Continental countries like Brazil have experienced opposite regional effects in the same ENSO phase, thus reducing the overall country impacts. On the other hand, countries like Colombia experience significant impacts in both ENSO phases due to their smaller latitudinal extension. To illustrate the ENSO impacts on the hydropower production in Colombia, three different years are analyzed. Table 2 provides the ONI for three years with very different ENSO intensities. The warm periods in red and the cold periods in blue are based on a threshold of $+/-0.5^{\circ} \mathrm{C}$. The successive negative ONI values below the threshold in 2011 indicate a year with high La Niña intensities. The year of 2014 presented no significant El Niño/La Niña intensities. The successive positive ONI values above the threshold in 2015 indicate a year with high El Niño intensities.

Table 2. Oceanic Niño Index in 2011 (La Niña), 2014, and 2015 (EI Niño)

\begin{tabular}{|cccccc|}
\hline Year & Jan-Feb-Mar & Feb-Mar-Apr & Mar-Apr-May & Apr-May-Jun & May-Jun-Jul \\
\hline $\mathbf{2 0 1 1}$ & -1.1 & -0.8 & -0.6 & -0.5 & -0.4 \\
\hline $\mathbf{2 0 1 4}$ & -0.4 & -0.2 & 0.1 & 0.3 & 0.2 \\
\hline $\mathbf{2 0 1 5}$ & 0.6 & 0.6 & 0.8 & 1.0 & 1.2 \\
\hline Year & Jun-Jul-Aug & Jul-Aug-Sep & Aug-Sep-Oct & Sep-Oct-Nov & Oct-Nov-Dec \\
\hline $\mathbf{2 0 1 1}$ & -0.5 & -0.7 & -0.9 & -1.1 & -1.1 \\
\hline $\mathbf{2 0 1 4}$ & 0.1 & 0.0 & 0.2 & 0.4 & 0.6 \\
\hline $\mathbf{2 0 1 5}$ & 1.5 & 1.8 & 2.1 & 2.4 & 2.5 \\
\hline
\end{tabular}

Source: Data from NOAA (2019b)

Figure 4 shows the active (useful) daily hydroelectric water capacity volume in Colombia for the same years of Table 2. The year with higher capacities (2011) corresponded to the year with high La Niña intensities. On the other hand, the year with lower capacities (2015) corresponded to the year with high El Niño intensities. It clearly shows how hydroelectricity output in Colombia is affected by ENSO phases with high intensities. 


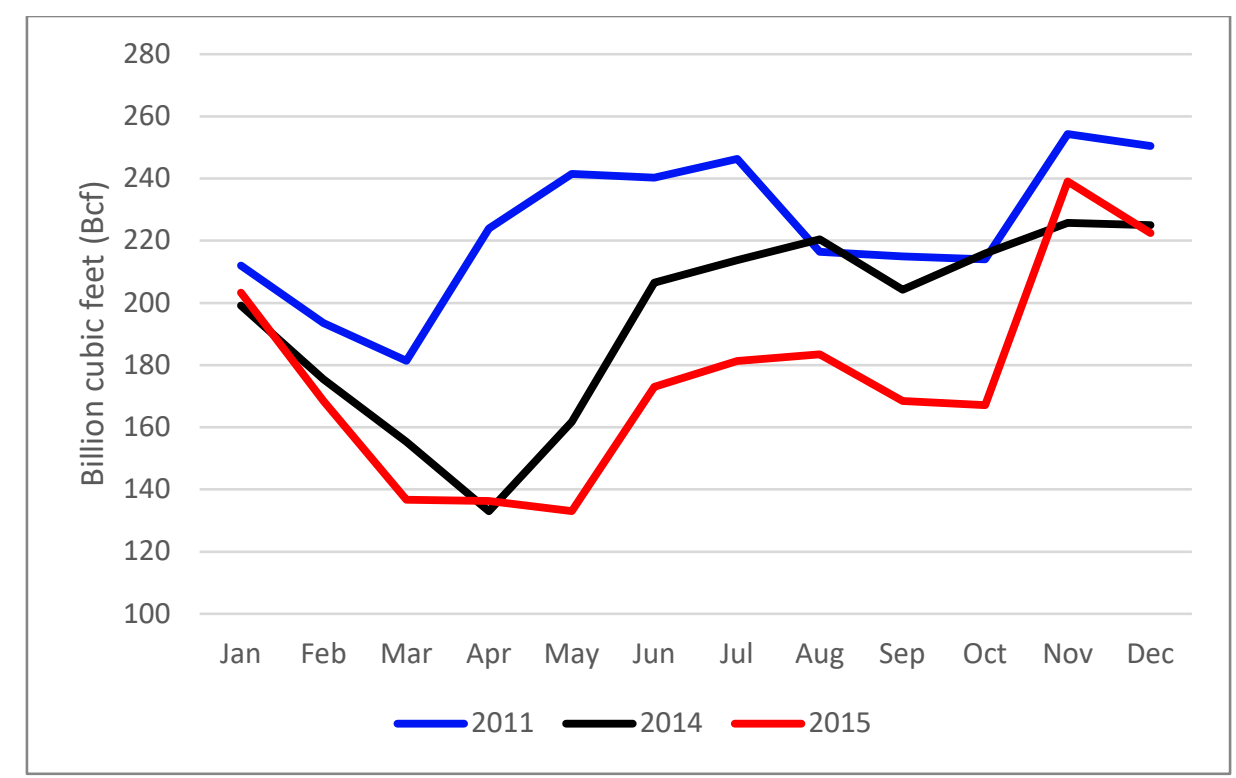

Source: Data from XM Colombia (2019)

Figure 4. Active daily hydroelectric capacity volume in Colombia

In addition to ENSO, other regional weather phenomena can also affect rainfall and consequently the hydropower production in specific regions. Text Box 1 briefly describes the recent droughts caused by a regional weather phenomenon in Southeastern Brazil. 


\section{Text Box 1. Recent Droughts in Southeastern Brazil}

The South Atlantic Convergence Zone (SACZ) is a hydrological channel that brings moisture from the Amazon region to the Southeastern part of Brazil. It usually occurs in late spring and most parts of summer. The South Atlantic Subtropical High (SASH) is a high air pressure (anticyclone) system whose center is generally located between the continents of Africa and South America. When the SASH is positioned in the central part of the Atlantic Ocean, it facilitates the formation of rainfall areas in coastal regions of Brazil. When it is positioned in the continental area, however, it may work as an atmospheric block that prevents the formation of the SACZ. Brazil experienced intense droughts in the years of 2014-2017, which were mainly caused by a continental SASH that prevented the formation of the SACZ. This phenomenon significantly reduced the amounts of rainfall in the southeastern part of the country, especially in the states of São Paulo, Minas Gerais, and Espírito Santo, which together account for nearly $25 \%$ of the total hydroelectric capacity in Brazil. Figure 5 shows the average water storage capacity in the Brazilian Southeast/Central-West subsystem (which comprises the aforementioned states) in 2014 in comparison with the long-term average water storage capacity (from 1931 until 2014).

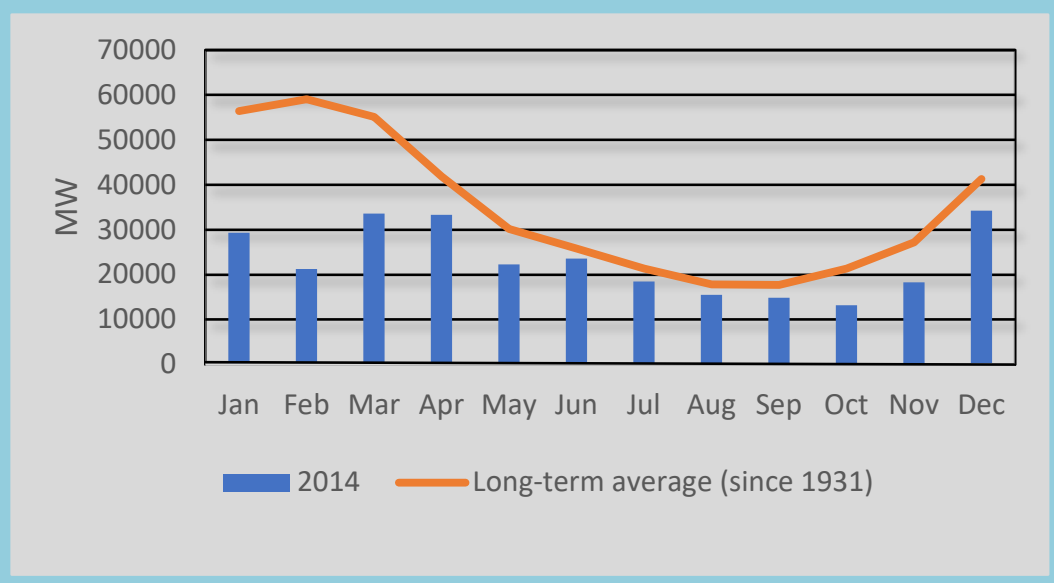

Source: Data from MME (2019a)

Figure 5. Average water storage capacity in the Brazilian Southeast/Central-West subsystem

\subsubsection{Increasing VRE integration}

Colombia is an example of a South American country heavily dependent on hydropower that has been facing increasing risk and reliability concerns primarily due to the variation in rainfall and the increasing adoption of diversion hydropower plants, which calls for greater medium- and long-term flexibility. Other countries, such as Argentina, Brazil, and Chile also face hydropower variability concerns. However, they are also experiencing significant penetration of VRE, which calls for greater short-term flexibility. Figure 6 shows the aggregated VRE (wind and solar) installed capacity in these three countries from 2010 to 2019 (as of July). VRE capacity increased from 1,107 MW in 2010 to nearly $24,000 \mathrm{MW}$, accounting for about $10 \%$ of the total installed capacity in 2019. 


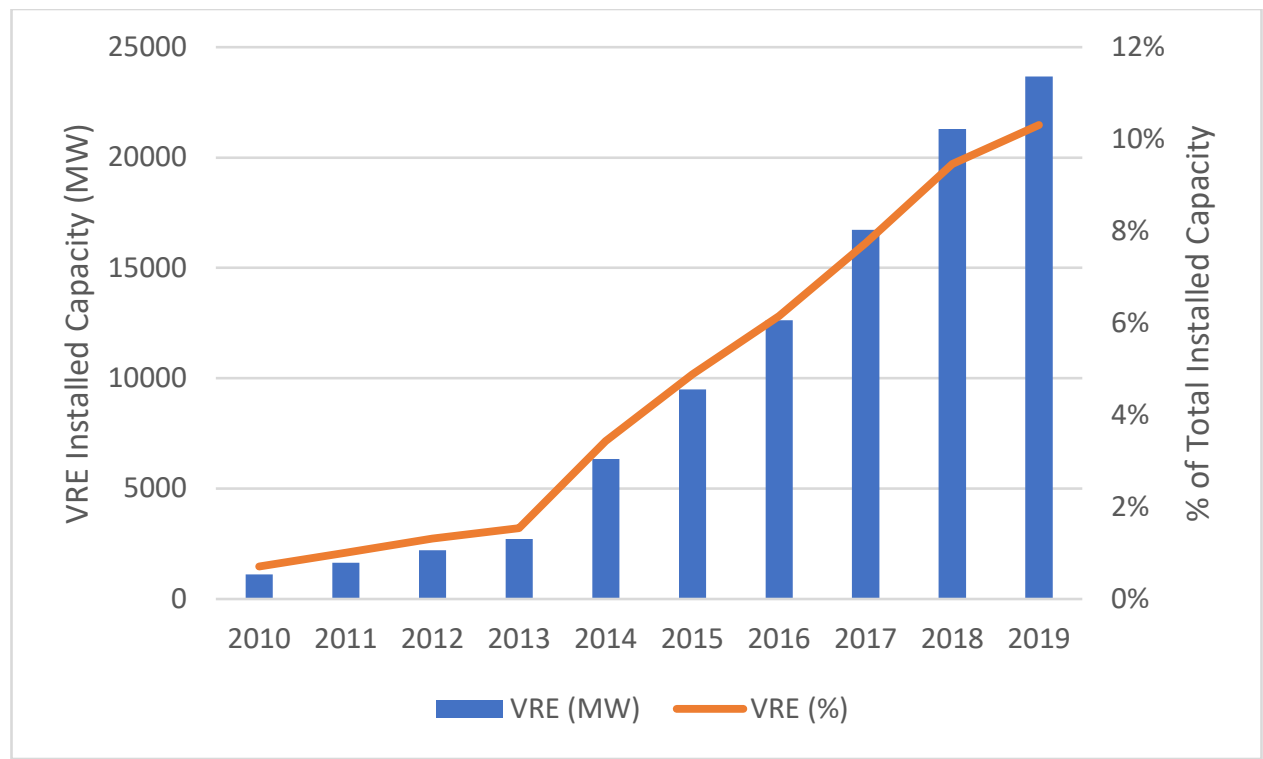

Source: Data from CAMMESA (2019), MME (2019), and CNE (2019a)

Figure 6. Aggregated VRE installed capacity in Argentina, Brazil, and Chile

The dependency on hydropower and the increasing integration of VRE pose different challenges for the electricity sector in South American countries. Hydropower variations are typically seasonal, and the effects of abnormal rainfall periods should be carefully considered in the medium and long-term energy planning strategies. On the other hand, wind and solar power are variable and somewhat uncertain by nature, thus causing short-term planning concerns. In particular, Brazil has been facing flexibility challenges due to both hydropower dependency and VRE growth.

\subsubsection{Thermal power inflexibility and fuel supply uncertainties}

Additional drivers of the need for flexibility in South America, especially in those countries more dependent on thermal power generation such as Argentina and Chile, include the inflexibility (in terms of capacity, speed, duration) of existing thermal power plants and the uncertainties associated with fuel production, consumption, imports, and exports. This is especially true for older fossil fuel or nuclear plants that have limited ability ramp up or down output rapidly, or are expensive to start up and shut down as conditions change.

\subsection{Natural Gas as an Increasingly Important Generation Option in South America}

Natural gas is an important option to provide a critical source of flexibility to the electricity sector in South America. From 2014 to 2018, more than 35\% of the total natural gas consumed in Argentina, Brazil, Chile, and Colombia was used for electricity generation (Figure 7). Despite holding significant natural gas reserves, South America remains a net importer as demand has grown rapidly and a shortage of upstream investment, limited transport infrastructure, as well as regulatory barriers have prevented sufficient investment in domestic supply. Argentina, with its Vaca Muerta shale formation, and Brazil, with its offshore Pre-Salt fields, have significant natural gas reserves. Both countries, however, face uncertainties and challenges concerning future domestic gas production and transportation. There is a potential for LNG to serve a more 
prominent role, at least in the short to medium term, while long-term outcomes will depend on how domestic gas exploration and development proceeds, among other factors. Argentina, Brazil, and Chile have imported LNG mainly through the spot market for more than ten years. Colombia joined the group of LNG importers in 2016. Section 3 provides more information on natural gas trade in these key South American countries.

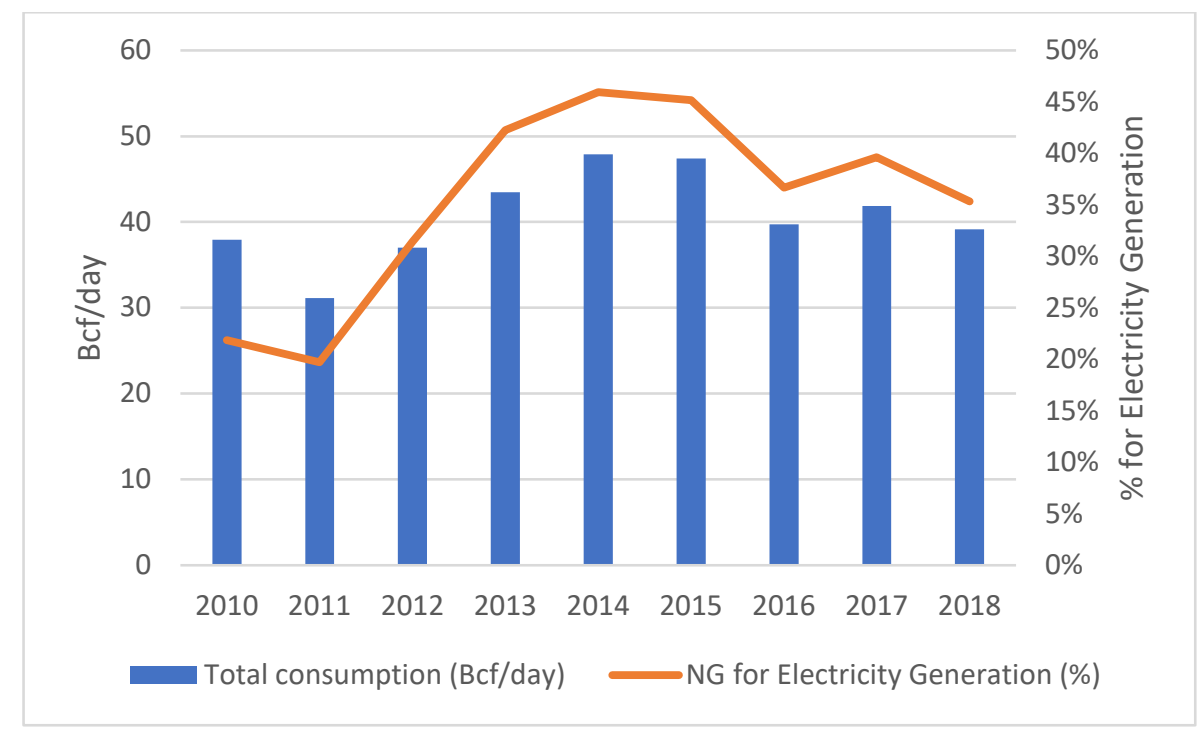

Source: Data from IAPG (2019), MME (2019b), CNE (2019c), and PROMIGAS (2019)

Figure 7. Aggregated natural gas consumption in Argentina, Brazil, Chile, and Colombia

Many oil-fired power plants are being converted to burn cheaper and cleaner natural gas and many countries have plans to gradually reduce or phase out coal power generation. Social and environmental opposition to new hydroelectric projects has also hastened the move towards natural gas, although some countries may also oppose the greater use of fossil fuels due to their emissions. Furthermore, natural gas is increasingly used to support and complement VRE sources, including wind and solar. Sections 3-7 provide additional information on the potential for greater use of natural gas as a low-cost and flexible source of energy supply. Further analysis is needed to determine how much of that natural gas supply might come from domestic production as well as from cross-border pipeline and LNG imports, and the specific policies and business models appropriate for each country.

\subsection{Policy Options to Enhance Flexibility}

One key challenge of ensuring power system flexibility is to find resource adequacy strategies (i.e., strategies that ensure sufficient resources to satisfy the forecasted load) that can be adapted to the reality of each country in order to ensure proper revenue sufficiency (i.e., sufficient revenue to sustain a certain resource adequacy strategy). This includes domestic generation options, demand-side management, fuel imports, flexible technologies, as well as power system interconnections between regions of the same country and also between strategic neighboring countries. The flexibility issues and potential solutions in both electricity and natural gas sectors are illustrated in Figure 8 and discussed as follows. 


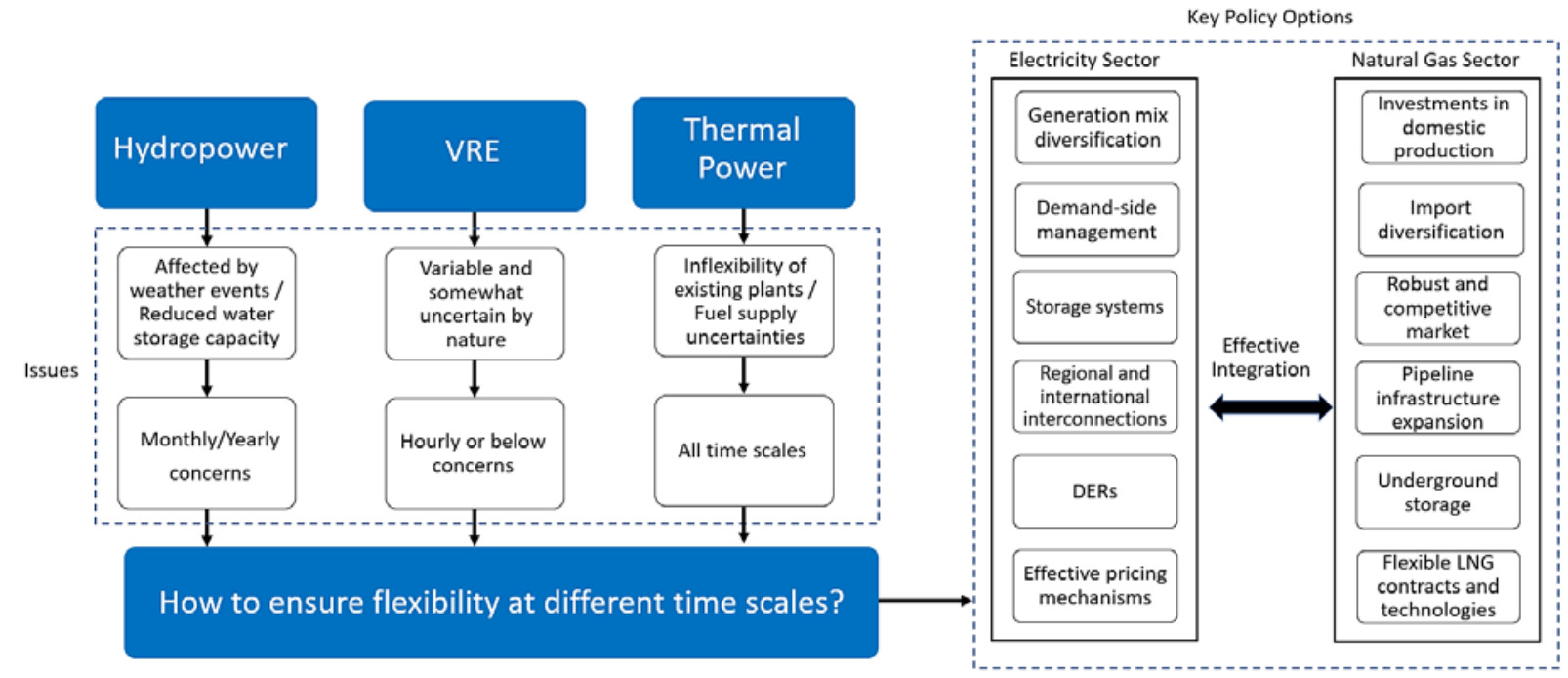

Figure 8. Flexibility issues and options in power systems of key South American countries

\subsubsection{Electricity Sector Policy Options}

In the electricity sector, various options exist on both the generation and demand sides (ranging from centralized and large-scale solutions to small-scale and distributed alternatives) as well as opportunities for enhancements in the existing system/market planning and operation models.

Generation Mix Diversification: A diverse generation mix is essential to ensure greater flexibility provision by reducing the dependence on a single fuel or resource type, leveraging the complementary strengths of various generation options, and mitigating fuel cost volatility. This includes new types of generation as well as the retrofit of existing inflexible thermal power plants.

Demand-side Management: Historically, supply-side assets have been used as the main sources of flexibility in many countries (IRENA 2019). However, demand-side assets can also be providers of short-, medium-, and long-term flexibility. This includes price-based or incentivebased mechanisms that aim to adjust electricity demand within certain limits in order to improve grid operation and electricity market performance.

Storage Systems: Storage options include batteries and thermal storage for short-term and lowcapacity needs as well as emerging technologies for longer-duration and larger-scale capacity (e.g., systems able to convert electricity into ammonia and hydrogen). While traditional hydropower can serve as a seasonal storage approach, pumped hydro storage, in particular, is a promising option capable to provide flexibility at various time scales.

Regional and International Interconnections: Transmission capacity expansion could foster greater flexibility and energy exchange between regions of the same country and also between strategic neighboring countries in order to better achieve regional complementarities (and even the opposite effects of weather events in different regions) and maximize the use of VRE.

Distributed Energy Resources (DERs): In addition to centralized and large-scale options, distributed energy resources (DERs) (e.g., distributed generation, storage, and demand response) 
are also expected to play a bigger role in South America. If properly controlled, DERs can provide additional flexibility, contribute to the reduction of network losses, as well as defer or replace the need for specific transmission or distribution grid expansion and upgrades. As innovative and affordable DER technologies emerge, the number of end-users interested in investing in such technologies is expected to increase. In addition, new types of incentives, financing options, and diversified markets for DERs can be further investigated to identify technical and regulatory opportunities for greater DER integration.

Effective Pricing Mechanisms: The aforementioned options for the electricity sector depend on an effective coupling of market and system operations and planning with proper economic signals and a detailed representation of the constraints that may directly affect generation availability and electricity prices. For example, the adoption of day-ahead, intra-day, and realtime electricity markets would make it possible to determine electricity prices with finer temporal resolution and boost the provision of short-term flexibility. Capacity markets, on the other hand, can be designed to incentivize flexibility at longer time scales.

\subsubsection{Natural Gas Sector Policy Options}

In the natural gas sector, policy options include infrastructure expansion (i.e., pipelines, underground storage, and LNG terminals) along with investments in domestic production and import diversification.

Investments in Domestic Production: Such investments are essential to ensure lower gas prices reduce the dependency on fuel imports and, thus, allow gas-fired power plants to provide affordable flexibility services. In particular, investments in diversified natural gas options (e.g., conventional, unconventional, associated, and non-associated) can also help several countries to mitigate overall production uncertainties and technical challenges.

Import Diversification: When domestic production is insufficient to meet demand, a diversified and robust natural gas import portfolio is essential to reduce the dependency on specific suppliers and contracting mechanisms. The available import options should consider short-, medium-, and long-term as well as seasonal flexibility needs.

Robust and Competitive Markets: Natural gas markets should be designed to attract investments in production, transmission, and distribution in order to reduce monopolies and stimulate greater competitiveness, lower prices, and better services. Pricing mechanisms should consider technical constraints related to production, transmission, and distribution and ensure the revenue sufficiency of producers, consumers (e.g., flexible thermal power plants), and intermediary agents.

Pipeline Infrastructure Expansion: The expansion of onshore and offshore pipelines could facilitate greater domestic production and provide natural gas service to new locations, thus increasing the overall and regional system flexibility capabilities.

Underground Storage: The development of underground storage reservoirs would allow greater domestic production, mitigate supply and demand uncertainties and fluctuations, and increase the flexibility of supply, thus allowing a greater use of natural gas in many applications such as 
power generation. Developing underground storage, however, is often limited by geological constraints.

Flexible LNG Contracts and Technologies: The increasing flexibility of LNG contracts (in terms of volumes, duration, etc.) and technologies (floating storage and regasification units (FSRUs), floating liquefaction units, etc.) (see Section 3) could also help many South American countries to mitigate natural gas supply and demand uncertainties and fluctuations, and allow gas-fired power plants to provide greater flexibility in the electricity sector.

\section{Summary}

An integrated planning and operation framework for the electricity and natural gas sectors could potentially close the existing gap between the two sectors in South American countries. For instance, the power system planning and dispatching models that already take into account different hydrological conditions could also consider the constraints associated with the natural gas sector such as gas production, storage, transportation, and LNG storage/regasification limits, thus providing more realistic solutions and also mitigating price fluctuations associated with natural gas availability (Barroso et al., 2008).

\section{References for Section 2}

Barroso, L. A.; Rudnick, H.; et al. 2008, "LNG in South America: The markets, the prices, and the security of supply," in Proc. IEEE Power and Energy Society General Meeting, July, 2008.

CNE. 2019c. “Consumo Mensual GN.” Accessed May 2019: https://www.cne.cl/estadisticas/ hidrocarburo/

Comisión Nacional de Energía de Chile (CNE). 2019a. "Capacidad instalada de generación." Accessed May 2019: https://www.cne.cl/estadisticas/electricidad/

Comisión Nacional de Energía (CNE). 2019b. "Information and Statistics." Accessed March 2019: https://www.cne.cl/en/nuestros-servicios/reportes/informacion-y-estadisticas/

Comisión Nacional de Energía (CNE). 2019c. "Consumo Mensual GN." Accessed May 2019: https://www.cne.cl/estadisticas/ hidrocarburo/

Compañía Administradora del Mercado Mayorista Eléctrico (CAMMESA). 2019. "Informe Mensual del MEM y MEMSP.” Accessed May 2019: http://portalweb.cammesa.com/memnet1/ Pages/ descargas.aspx

Ela, E.; Milligan, M.; et al. 2018. "Incentivizing flexibility in system operations," in Electricity Markets with Increasing Levels of Renewable Generation: Structure, Operation, Agent-based Simulation, and Emerging Designs." Springer, pp. 95-127.

Instituto Argentino de Petroleo y del Gas (IAPG). 2019. "Estadisticas Interactivas.” Acessed April 2019: http://www.iapg.org.ar/estadisticasnew/

International Energy Agency (IEA)/21 ${ }^{\text {st }}$ Century Power Partnership (21CPP). 2018a. "Status of Power System Transformation 2018 - Advanced Power Plant Flexibility," OECD/IEA, Paris. 
International Group of Liquefied Natural Gas Importers (GIIGNL). 2019. "The LNG Industry GIIGNL Annual Report 2019.” Accessed May 2019: https://giignl.org/sites/default/files/ PUBLIC_AREA/Publications/giignl_annual_report_2019-compressed.pdf

International Renewable Energy Agency (IRENA). 2019. "Power System Flexibility for the Energy Transition - Part 1: Overview for Policy Makers.” Accessed May 2019: https://www.irena.org/-/media/Files/IRENA/Agency/Publication/2018/Nov/IRENA Power system flexibility 1 2018.pdf?la=en\&hash=72EC26336F127C7D51DF798CE19F477557CE9A $\underline{82}$

Milligan, M.; Frew, B.; et al. 2015. "Advancing System Flexibility for High Penetration Renewable Integration.” NREL/TP-6A20-64864. Golden, CO: National Renewable Energy Laboratory.

Ministerio de Economía y Finanzas Públicas de Argentina. 2009. "El Mercado Eléctrico Argentino.” Accessed May 2019: https:/www.economia.gob.ar/peconomica/informe/ notas tecnicas $/ 22 \% 20$ NOTA $\% 20$ TECNICA $\% 20$ Nivel $\% 20 \mathrm{de} \% 20$ Actividad $\% 20 \% 20 \mathrm{inf} \% 2070$. pdf

Ministerio de Minas y Energía de Colombia (Minenergía). 2010. "Sector Energía Eléctrica.” Accessed May 2019: https://www.minenergia.gov.co/documents/10180/23400/ 05ENERGIA2010-2011.pdf/770a198d-d4ee-4687-b74c-74592b403ae6

Ministério de Minas e Energia (MME). 2019a. "Boletim de Monitoramento do Sistema Elétrico.” Accessed May 2019: http://www.mme.gov.br/web/guest/secretarias/energiaeletrica/ publicacoes/boletim-de-monitoramento-do-sistema-eletrico

MME. 2019b. "Boletim de Acompanhamento da Indústria de Gás Natural.” Accessed April 2019: http://www.mme.gov.br/web/guest/secretarias /petroleo-gas-natural-ecombustiveisrenovaveis/ publicacoes/boletim-mensal-de-acompanhamento-da-industria-de-gasnatural? 20 displayStyle $=$ descriptive \& $\mathrm{p}$ p id=20

National Oceanic and Atmospheric Administration (NOAA). 2019a. "Climate Prediction Center (OPC) Oceanic Nino Index.” Accessed May 2019: https://data.noaa.gov/dataset/dataset/ climateprediction-center-cpcoceanic-nino-index

NOAA. 2019b. “Cold \& Warm Episodes by Season.” Accessed May 2019: https://origin.cpc.ncep.noaa.gov/products/analysis_monitoring/ensostuff/ONI_v5.php

PROMIGAS. 2019a. "Informe del Sector Gas Natural.” Accessed May 2019: http:/www.promigas.com/Es/Noticias/Paginas/Informes.aspx

XM Colombia. 2019. “Informe Oferta y Generación.” Accessed May 2019: https://www.xm.com.co/Informes\%20Mensuales\%20de\%20Anlisis\%20del\%20Mercado/02_Info rme_Oferta_y_Generacion_03_2019.pdf 


\section{Natural Gas Trends for South America}

\subsection{Trends}

Natural gas is the third most prominent source of primary energy in the world after oil and coal, although in South America it plays a relatively minor role in overall energy use. Industrial, transportation, buildings (for water and space heating) and electric power are the leading consuming sectors of natural gas in South America. The participation of natural gas in these sectors varies by region.

\subsubsection{Characteristics of Natural Gas}

Globally, natural gas is growing as a source of energy because it has certain characteristics that are appealing from the perspective of governments, consumers and developers, including:

1) Natural gas emits approximately half of the burner-tip carbon emissions and fewer air pollutants than coal per unit of energy, which appeals to governments looking to meet sustainability and pollution reduction goals (Middleton et al. 2017)

2) Natural gas power plants are, in general, more flexible than coal or nuclear, which becomes an important characteristic as the share of variable sources of renewable energy increase in the power sector (Trabish 2014)

3) The global availability of natural gas is growing due to the increase of LNG exports and the adoption of technologies that makes the extraction of unconventional gas - such as shale and tight gas - cost-effective (International Gas Union 2019).

In recent years, the global trade of natural gas via maritime shipments has increased more rapidly than cross-border pipeline shipments of gas (Figure 12). Long-distance trading and new extraction technologies have created a global gas market with numerous and diverse suppliers and consumers where natural gas is a fungible commodity, thus enabling importing countries to diversify the sources of their imports, and to demand better and more flexible contract terms from suppliers.

South America is still a new and small market for natural gas. To understand the outlook of natural gas in South America, it is important to understand the dynamics and current situation of the global market for natural gas.

\subsection{Natural Gas Demand}

The top natural gas consumers in 2018 were the United States, Russia, China, Iran, Japan and Canada. Global consumption of natural gas grew by 28\% between 2008 and 2018, while in the later year alone, demand was up by $5.3 \%$, one of the largest year-over-year increases in the last three decades (BP 2019).

As an example, since 2000, China has generally experienced a double-digit year-to-year growth in gas consumption. Since 2017, China's coal-to-gas switching policy has encouraged more use of natural gas in industry and buildings over coal in order to reduce air pollution. These policies and the rebound of China's heavy industry from a three-year slump contributed to an $18 \%$ 
increase in gas consumption in China in 2018 (Miyamoto and Ishiguro 2018; BP 2019). Additionally, the demand for natural gas increased by $10 \%$ in the United States - the largest annual increase on record for the largest gas-consuming country - which also contributed to the global increase in consumption in 2018 (U.S. Energy Information Administration (EIA) 2019d).

Japan is the largest importer of natural gas in the world. After the Fukushima nuclear accident in 2011, Japan's reliance on imported LNG rose dramatically to offset nuclear plants that were at least temporarily closed due to overall public concern about the safety of nuclear power. More recently, Japan announced plans to re-start at least some of its nuclear plants, lowering the country's reliance on imports (Stiles 2016; Japanese Ministry of Economy, Trade and Industry 2016).

Other significant markets for LNG are Europe, China, and South Korea (Deloitte Center for Energy Solutions 2016).

\subsection{Natural Gas Supply}

Natural gas is extracted from underground deposits and distributed through pipelines to consumption centers or liquefaction facilities for export. The liquefaction of natural gas compresses its volume to about one six-hundredth of its original volume, making it easier and more cost-effective to ship over long distances. LNG is safer to transport because it is nonflammable and non-toxic. Historically, the United States and Russia have been the two largest natural gas producers in the world, followed by Iran, Canada, Qatar, and China (Figure 9) (BP 2019; Deloitte Center for Energy Solutions 2016).

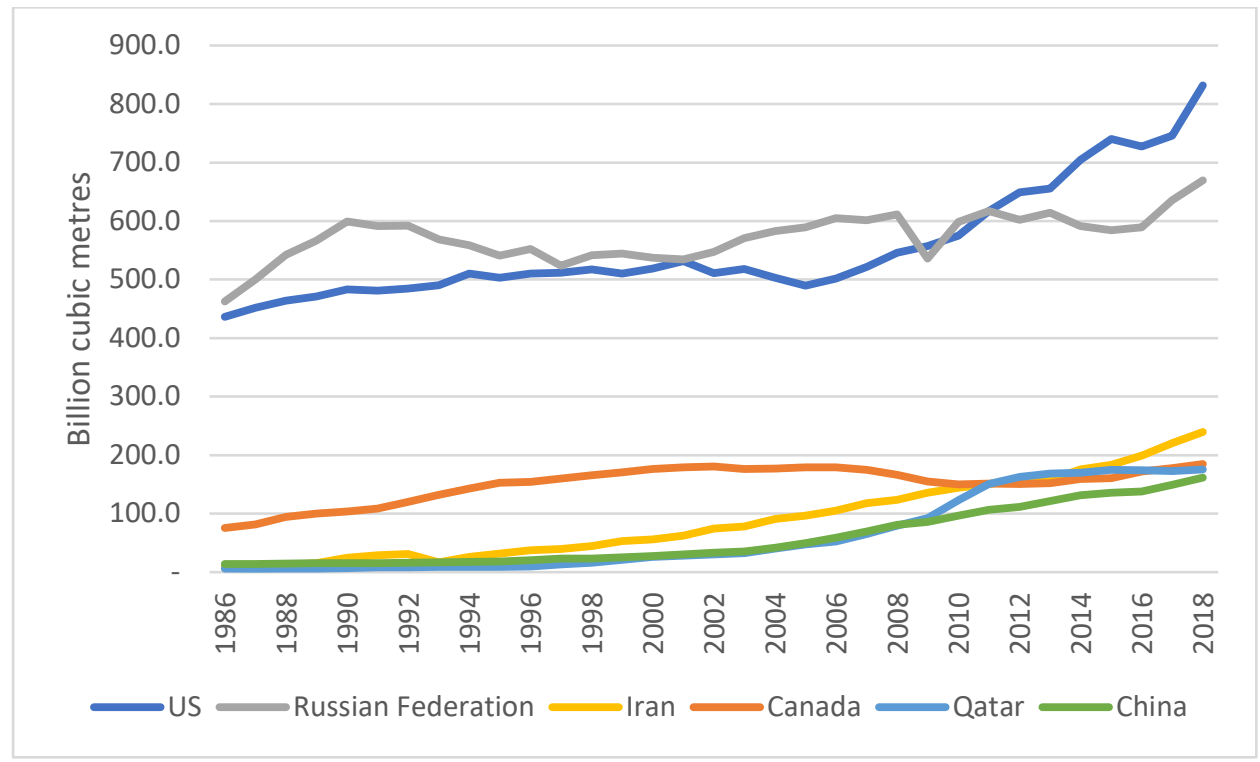

Source: Data from BP (2019)

Figure 9. Leading natural gas producers 


\subsubsection{LNG Build-Up and The Shale Gas Revolution}

For decades, Russia (before and after the dissolution of the Soviet Union), focused its export strategy on Europe and was the primary or only source of natural gas for many countries in the continent. Russia's monopolistic status allowed the country to require take-or-pay and destination clauses in its contracts, which required payments to Russia for any gas not consumed below a certain quota and prevented buyers from redistributing the gas to other countries, respectively (Mitrova and Boersma 2018).

The United States, the largest global producer since 2011, consumed most of its production and only exported small amounts to Mexico and Canada. In the 2003 to 2006 period, the gap between the consumption of natural gas in the United States and its domestic supply started to grow significantly, making the U.S. market increasingly reliant on imports. The United States appeared as an attractive export market for gas producers around the globe and numerous LNG facilities were built in this period in Qatar, Algeria and other producing countries targeting a perceived growing market for American imports (Mitrova and Boersma 2018).

The U.S. strategy to address the looming deficit was to build up its LNG-import infrastructure and to invest in developing drilling technologies that could extract the vast reserves of shale gas in the country. A combination of advances in underground visualization techniques, horizontal drilling, and hydraulic fracturing allowed the United States to unlock vast amounts of natural gas reserves. Between 2006 and 2008, the estimated natural gas reserves in the United States increased 35\% mostly due to shale gas reserves, which had become cost-effectively recoverable through the use of new drilling and hydraulic fracturing technologies (Mouawad 2009; Massachusetts Institute of Technology 2011).

\subsubsection{LNG Market Dynamics}

Unlocking shale reserves in the United States had repercussions around the globe, even before the U.S. LNG exports started to gain momentum in 2016. Two large projects in Russia that had been planned with the U.S. demand in mind had to be delayed or cancelled, and the LNG from liquefaction facilities that became operational in 2008 and 2009 in Qatar, Algeria and other countries had to be redirected to Europe and Asia (Mitrova and Boersma 2018).

Qatar, Australia, Malaysia, the United States, Nigeria, and Russia were the top 6 exporters of LNG in the world at the end of 2018, with Australian and U.S. output growing the fastest (Figure 10) (BP 2019). 


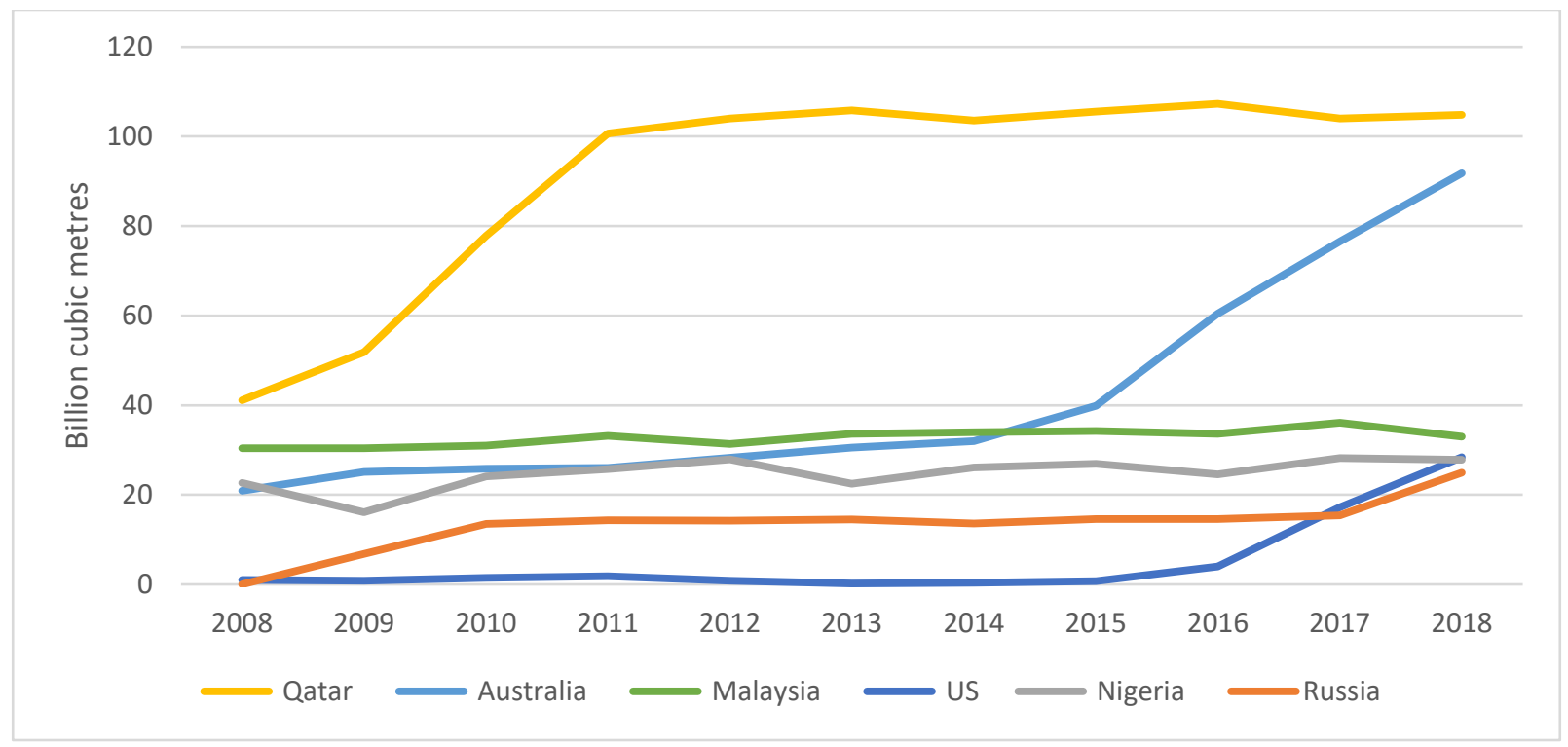

Source: Data from BP (2019)

Figure 10. LNG exports by top exporting countries

\subsubsection{Natural Gas Prices}

The relatively fast reversal in the prospect of the United States becoming a large market for LNG imports created an oversupply of LNG in the rest of the world. In 2016, natural gas prices worldwide declined to a 17-year low (Figure 11), largely associated with the decline in global petroleum prices at that time. Japan restarted some of its nuclear plants to reduce its dependence on gas and China's demand growth fell somewhat due to a weakening economy. New liquefaction facilities had come online in Australia and other countries that increased capacity expecting to supply a market that did not materialize. At the start of 2017, the global LNG capacity was over 300 million tonnes per year, even though the total LNG trade in 2016 was 268 million tonnes. U.S. exports grew almost six-fold between 2015 and 2016, although they still represented only $1 \%$ of global LNG exports (Japanese Ministry of Economy, Trade and Industry 2016; Tan 2016; BP 2019; Finn 2017). 


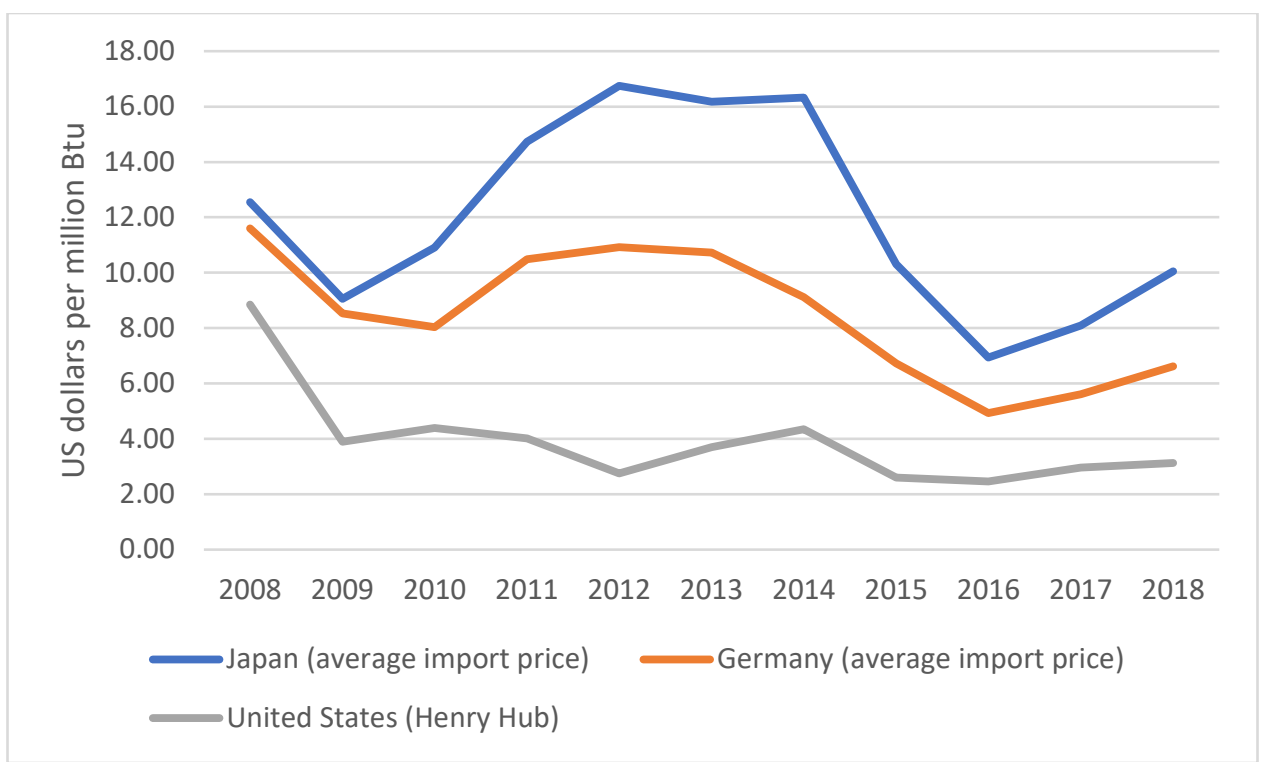

Source: Data from BP (2019)

Figure 11. Natural gas prices in selected countries

\subsubsection{LNG and Natural Gas Diversity and Flexibility}

Gas abundance also empowered buyers to demand more flexible contracts. In Europe, countries such as Poland and Lithuania built facilities to import LNG, which reduced the countries' reliance on Russian gas and enabled them to get better contract terms and prices from Russia. (Mitrova and Boersma 2018; Patzek, Male, and Marder 2013). The European Union, Japan and other jurisdictions have begun challenging destination clauses for LNG import contracts. These clauses may set a limit to the quantity of gas that can be resold, or the countries it can be resold to (Harding and Sheppard 2017; Vinter, Wilson, and Park 2018; Tsukimori 2017).

The expected growth in natural gas demand around the globe (which materialized in 2018), the production growth above demand in some natural gas producing countries, and the mobility of LNG have contributed to the tripling of the market for LNG in the last 20 years. The gap between inter-regional pipeline natural gas and LNG trades narrowed to the smallest on record in 2018 (Figure 12). LNG in 2018 contributed to $46 \%$ of total inter-regional trade in natural gas and the trend is for that percentage to keep growing as countries with vast reserves, such as the United States, Australia and Egypt, look to expand their export capacity. 


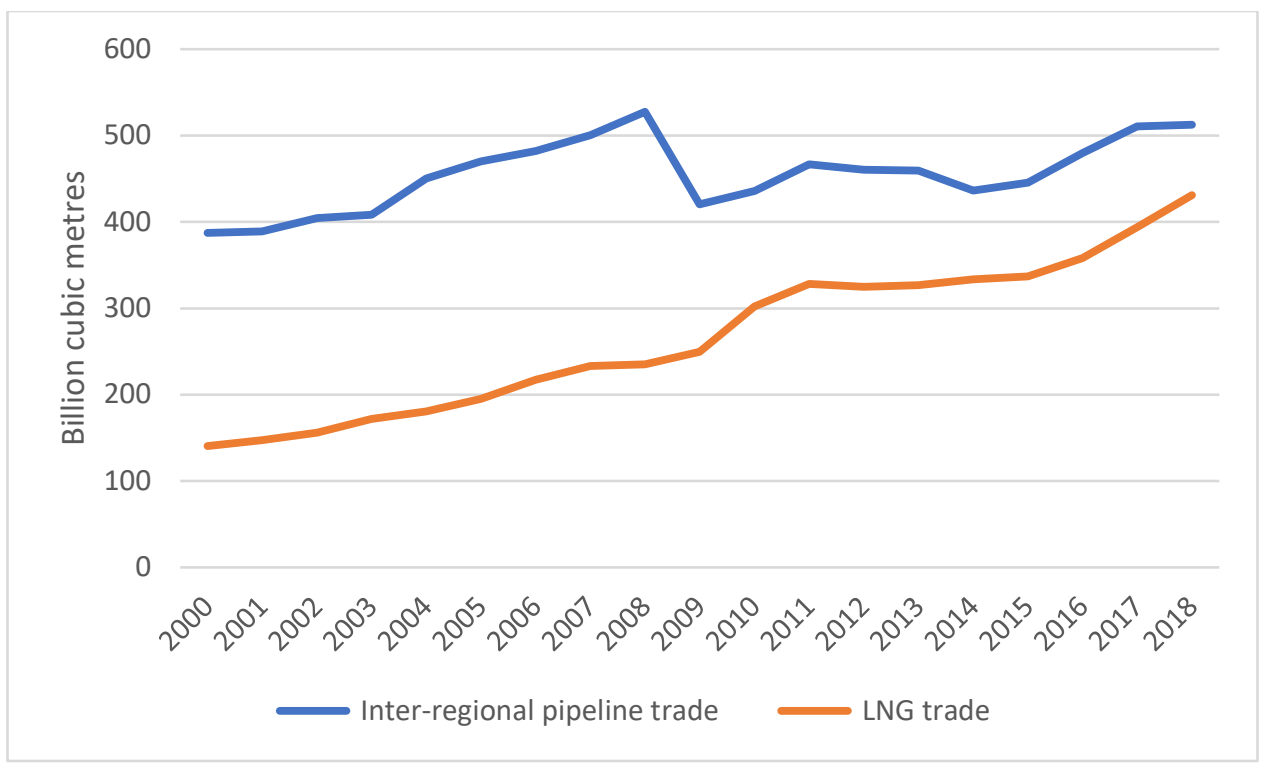

Source: Data from BP (2019)

Figure 12. Natural gas inter-regional trade

The trade gap between pipeline and liquefied natural gas is closing even though LNG is more expensive than pipeline gas due to liquefaction and transportation costs. LNG transportation costs depend on current charter rates, which in turn depend on demand and vessel fuel costs and can be very volatile (Rogers 2018). However, the geographical reach of pipelines is limited due to the cost of pipeline construction and the difficulty of traversing certain types of terrain with pipelines.

LNG contracts and deliveries are generally more flexible than pipeline trades; this can make LNG a preferred commodity for countries that have variable demand for natural gas and limited storage capability, such as Brazil. LNG is also convenient for countries like Japan that do not have access to natural gas pipelines from producing countries. Other countries with significant proven reserves, such as Colombia, import LNG because of the expense and time necessary to build the infrastructure to commercialize their domestic natural gas reserves. Argentina relies on flexible LNG to address its natural gas demand seasonality (high demand during the winter and low during warmer months).

Figure 13 shows the geographies covered by pipeline and LNG trade. LNG trade routes are more widespread. Countries like Argentina export through pipelines to neighboring countries while importing LNG because of the difficulty of reaching consumption centers with pipelines. 


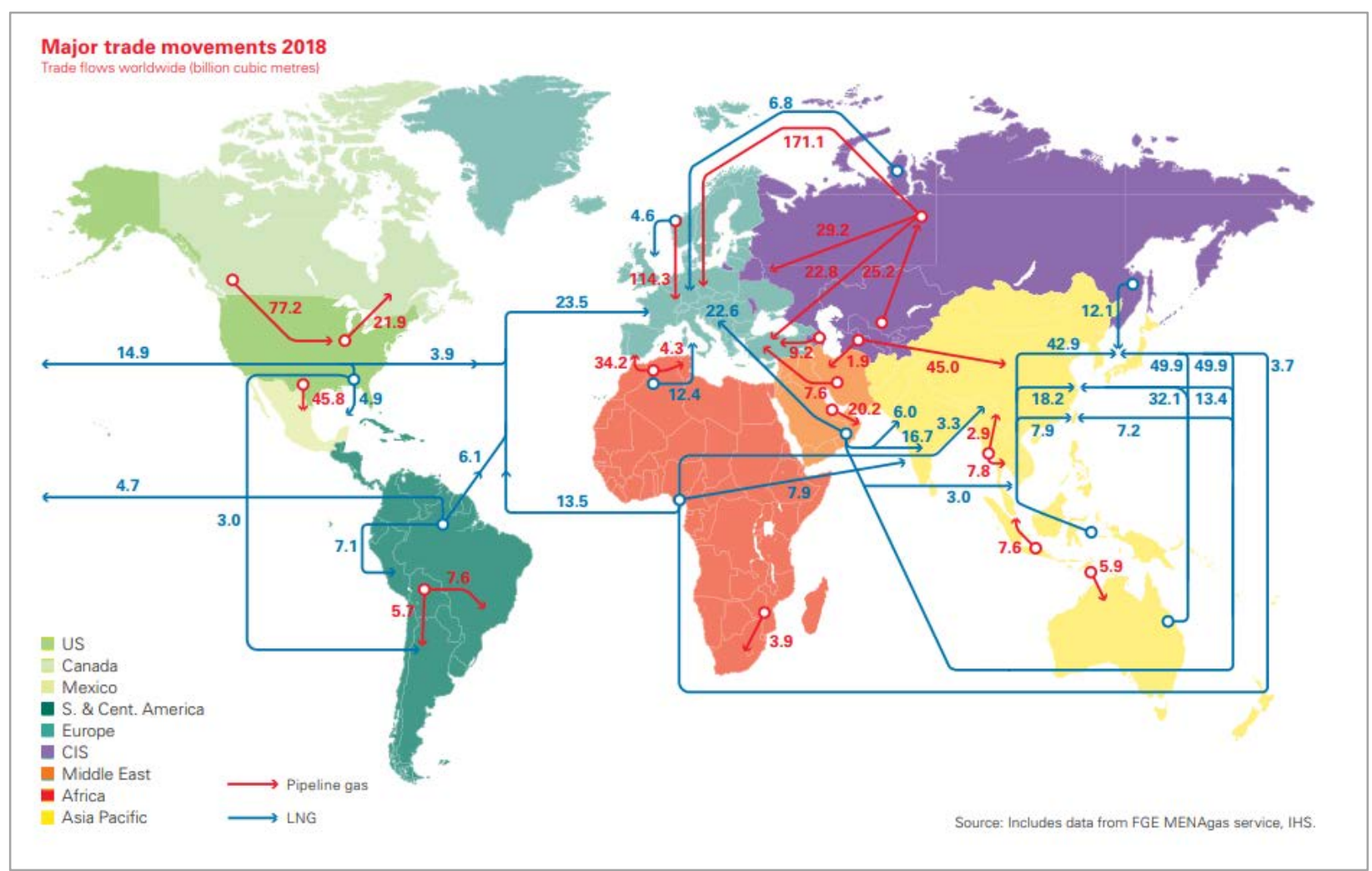

Source: BP (2019)

Figure 13. Major natural gas trade movements in 2018

\subsubsection{Floating Liquefaction and Regasification Facilities}

FLNG facilities produce, liquefy, store and transfer natural gas resources. FLNG units can be moored above offshore gas fields and are able to process, store and distribute large quantities of gas by liquefying it, reducing or eliminating the need for pipelines. These facilities are being bought or leased by exporting countries because they reduce the time and short-term cost for natural gas to reach the market and do not have any onshore footprint (Gallagher 2018). Similarly, LNG-importing countries can commission or lease floating storage and regasification units (FSRU) that can be deployed relatively fast to start LNG imports quickly. For example, Argentina's first LNG-receiving facility was Bahía Blanca's FSRU that allowed Argentina to import LNG between 2008 and 2018. Bahia Blanca was also the first FSRU in South America. When Argentina's domestic production increased, the country decided not to renew Bahía Blanca's FSRU lease and avoided having any stranded assets (Gilbert 2018).

\subsection{Continental Implications for South America}

In 2018, natural gas imports in South America totaled only 2.3\% of the global trade (BP 2019). Historically, the region has relied more heavily on intra-regional pipeline trade. Imports into South America as a percentage of total global trade peaked in 2014 at 4\%, when severe droughts affected the domestic production of hydropower between 2013 and 2015 (See Section 2). Since then, natural gas imports have declined by $29 \%$. The market for natural gas in South America is not projected to grow much in the near term, unless the region suffers repeated severe drought conditions. However, the region is working on lessening its reliance on hydropower by 
developing its natural gas infrastructure across the supply chain (Honoré 2016; International Finance Corporation 2019).

\subsubsection{Natural Gas Reserves}

South America has important natural gas reserves. Venezuela has the sixth largest proved natural gas reserves in the world and approximately $80 \%$ of the proven reserves in South America (BP 2019). Argentina and Brazil have the second and tenth largest technically recoverable shale gas resources worldwide, respectively (Table 3). About $84 \%$ of Brazil's reserves are located offshore (U.S. EIA 2013; BP 2019; U.S. EIA 2019a).

\section{Table 3. Proven and Unproven Technically Recoverable Natural Gas Reserves in Selected Countries of Latin America}

\begin{tabular}{|l|c|c|} 
& $\begin{array}{c}\text { Proven reserves } \\
\text { at end of } \mathbf{2 0 1 8} \\
\text { (trillion cubic feet) }\end{array}$ & $\begin{array}{c}\text { Unproven, technically } \\
\text { recoverable resources } \\
\text { (trillion cubic feet) }\end{array}$ \\
\hline Argentina & 12.2 & 802 \\
\hline Bolivia & 10.3 & 36 \\
\hline Brazil & 13.4 & 245 \\
\hline Colombia & 3.7 & 55 \\
\hline Peru & 12.4 & N/A \\
\hline Venezuela & 223.8 & 167 \\
\hline Chile & 0.16 & 48 \\
\hline
\end{tabular}

Source: Data from U.S. EIA (2013) and

Organization of the Petroleum Exporting Countries (2019)

\subsubsection{Production and Trade}

On average, South American countries produced 13.7 bcf per day and consumed 14.4 bcf per day in 2018. At least in theory, the region could be self-sufficient for $95 \%$ of its consumption. However, pipeline intra-regional gas trades have been fraught with uncertainty. The pipeline infrastructure could have provided the basis for a stable intra-regional market, but several problems occurred in the last two decades.

In 2001, Argentina was hit with a severe economic crisis that compromised its ability to supply gas to the countries it was exporting to - most notably Chile, a country that at the time relied heavily in imports from Argentina, but also Brazil and Uruguay (Honoré 2016).

In 2016, Colombia and Venezuela finished the construction of a pipeline that connected both countries. ${ }^{1}$ However, Colombia reduced exports to Venezuela in 2009 due to drought conditions that affected Colombia's hydropower production and stopped gas exports altogether in 2014 for

\footnotetext{
${ }^{1}$ Despite Venezuela's abundant natural gas reserves, the country's state-owned production company (Petróleos de Venezuela) has focused most of its attention on oil production. Most of the associated gas that is produced in Venezuela is reinjected into oil fields to aid production there.
} 
the same reason. In 2015, Venezuela announced that it would not renew a contract to import gas from Colombia citing irregular supply and frequent problems (Honoré 2016; Ulmer 2015; Alsema 2009).

Bolivian exports to Brazil have been relatively stable. However, in 2018, Bolivia failed to meet the minimum gas volumes required by its contract with Brazil and had to pay a penalty. Disputes about prices have increased between the two countries over the years and Petrobras, the Brazilian state-controlled vertically integrated oil corporation, does not plan to renew its contract with its Bolivian counterpart after it expires at the end of 2019. Petrobras will reportedly reduce imports from Bolivia gradually in the coming years. Private investors, however, may import gas from Bolivia through the existing pipeline (Lombrana, Gilbert, and Valle 2019; Argus Media 2019).

\subsubsection{Regional Drivers to Increase Natural Gas Infrastructure}

South America has historically relied on large hydropower plants to supply each country's domestic market for electricity. In 2018, 56\% of the electric power production in South and Central America came from hydropower plants (BP 2019). South America brought more hydropower online in 2018 than any other region in the world except for East Asia (International Hydropower Association 2019). However, severe droughts during the last two decades and future extreme weather conditions may increasingly challenge the conditions for hydropower generation in some countries of South America (International Hydropower Association 2019).

To mitigate the effects of hydropower variability, governments in the region have considered natural gas power generation as an alternative. Intra-regional gas trade instability and recurring droughts are among the most important factors that have contributed to the growth of the LNG market in South America, along with the flexibility of LNG import contracts, and the need to integrate variable renewable energy resources.

\subsubsection{Liquefied Natural Gas Imports to South America}

Argentina was the first country to build a regasification plant to import LNG in 2008. Chile and Brazil followed suit the year after. The relatively abundant global availability of LNG has enabled importing countries in South America to reduce their reliance on other countries of the region for natural gas imports.

Between 2009 and 2018, LNG imports to South and Central America more than quadrupled (Figure 14). In 2018, Chile, Argentina and Brazil were the largest importers and accounted for $75 \%$ of total imports to South and Central America (BP 2019). Bolivia, a country with abundant natural gas resources and a modest consumption, had for decades been a near monopoly in South America. However, Bolivia's exports to its neighboring countries fell by approximately $30 \%$ in 2018 (Lombrana, Gilbert, and Valle 2019; Barroso et al. 2008). 


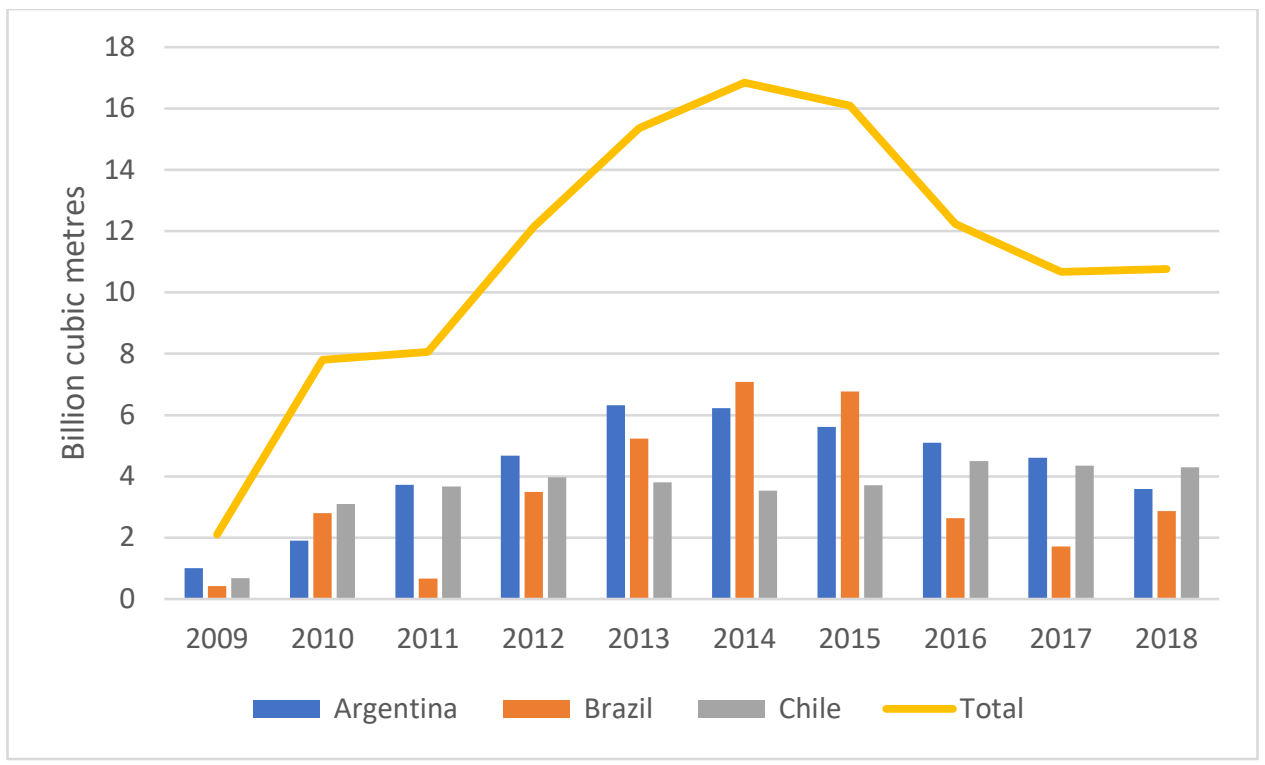

Source: Data from BP (2019)

Figure 14. LNG imports in selected countries of South America and total for South America and Central America

\subsubsection{Brazilian LNG Imports}

The sharp growth in imports in the last decade masks the annual variability of gas imports in the region. Between 2015 and 2016, gas imports in Brazil fell 62\% as the effects of the worst drought the country had experienced receded and hydropower and other forms of generation reduced the share of natural gas in the electric generation matrix (see Sections 2 and 5) (BP 2019; Torres Diaz 2018).

Brazil imports LNG from a variety of countries. In 2017, Nigeria and Angola were the largest suppliers of natural gas to Brazil. In 2018, the United States became the largest supplier, followed by Trinidad and Tobago and Russia (International Gas Union 2019; 2018). Brazil has a large potential for domestic production from its Pre-salt basins. ${ }^{2}$ However, the country does not have enough pipeline capacity to send gas from its deep-water fields at the rate demanded in the mainland and significant volumes of gas are re-injected (Torres Diaz 2018).

LNG, with its global availability from diverse countries and flexible contracts, has become a reliable option for Brazil to address the intra- and interannual variability of natural gas demand, particularly because the country does not have significant natural gas storage capabilities.

\footnotetext{
${ }^{2}$ Pre-salt refers to geologic layers formed before a salt layer accumulated above it (Waisberg 2011).
} 
Text Box 2. The Panama Canal and Natural Gas Trade between North and South America

In 2016, the Panama Canal was expanded to allow the transit of larger ships including, for the first time, LNG tankers. More than 600 LNG tankers have transited through the canal since the expansion. Initially, the administrators of the canal limited LNG transit to one tanker per day; but in October 2018, new rules helped increase the daily LNG traffic to up to five tankers. In 2018, the number of tankers traversing the canal increased 77\%, from 163 in 2017, to 290 (Chapa 2018; U.S. Energy Information Administration 2019c; Furtado 2019).

The Panama Canal is crucial to enable LNG trades between the LNG terminals in the Pacific and the Atlantic coasts. Nearly all the LNG existing and planned exporting facilities in the United States are or will be in the Gulf and East coasts, as well as five planned exporting facilities in Canada. The Panama Canal opens the market for South American terminals in the Pacific - in particular, the Chilean market. Colombia's next importing facility is planned on the country's Pacific coast (Natural Resources Canada 2018; Federal Energy Regulatory Commission 2019; BNAmericas 2019).

Seasonal complementarity presents an opportunity for gas trade between North and South America. However, droughts are a threat to gas trade between the two regions because they reduce the depth of the canal and, consequently, the cargo that the largest ships can carry, making such exports less competitive (Furtado 2019).

\subsubsection{Argentinian LNG Imports}

Since 2014, Argentina's LNG imports have declined due to the economic slowdown, warmer winters and the rapidly-growing domestic production. In 2018 the country both closed ${ }^{3}$ one of its importing facilities and resumed exports to Chile after 12 years, as domestic production from the Vaca Muerta play increased (Gilbert 2018; Excelerate Energy 2019; EFE 2018). Argentina has the second largest reserves of technically recoverable shale gas resources after China, and the only country outside of North America to commercially develop shale gas (U.S. EIA 2017). Currently, only 4\% of Vaca Muerta's play has been developed (La Nación 2019). The government is looking to attract investors to further develop Vaca Muerta as well as buyers for its natural gas. However, investors and developers have expressed reluctance to invest in the play due to "country risk" (Diamante 2019). Despite the enormous potential of Vaca Muerta, Argentina has not seen the same exponential grow as in the United States, due to political risk, access to capital, and regulatory uncertainty (Zborowski 2018; Paraskova 2018). Additionally, the memory of the crisis of 2001, in which Argentina defaulted on its commitment to supply gas to Chile and other neighboring countries, could hamper finding buyers in South America (Diamante 2019).

Argentina commissioned a liquefaction facility in 2019 to export LNG to countries in the Northern Hemisphere during Austral summers, when the country experiences an oversupply of gas (Owen 2019). Argentina does not have large-scale natural gas storage facilities and during

\footnotetext{
${ }^{3}$ More accurately, Argentina did not renew its contract with Excelerate Energy for a floating storage regasification unit that had been in operation since 2008 .
} 
the winter months, when domestic supply is insufficient to meet demand, has relied on pipeline imports from Chile and Bolivia and LNG imports from a diverse group of countries, including Qatar-Argentina's biggest supplier - the United States, Trinidad and Tobago, Equatorial Guinea, and Nigeria (TiempoSur 2016; International Gas Union 2019). Despite increasing production from Vaca Muerta, Argentina will continue to rely on imports until more pipeline capacity is built or large-scale storage is developed.

\subsubsection{Colombian LNG Imports}

Colombia has historically been able to meet domestic demand for natural gas with domestic production. However, natural gas consumption is experiencing consistent growth and its most productive fields are depleting and new developments are not coming online fast enough (Mendoza 2018; Pitts 2019). In 2016, Colombia opened its first LNG import terminal and imported its first cargo of natural gas - 0.03 million tonnes from Trinidad and Tobago_in 2017. In 2018, imports grew to 0.22 million tonnes from Trinidad Tobago and the United States (International Gas Union 2019; 2018).

In 2013, the U.S. EIA estimated that Colombia has 55 trillion cubic feet of technically recoverable shale gas, and in 2017 Colombia discovered a large offshore field in the Caribbean Sea. The government estimates that offshore discoveries could triple Colombia's gas reserves. Colombian imports of LNG are still modest compared to its neighbors in the continent. However, that could change in the short term because developing new fields will require years, particularly in deep water. Colombia is considering building a second LNG importing facility to anticipate a potential growth in the gap between domestic supply and demand (Mendoza 2018; Martinez 2017).

\subsubsection{Chilean LNG Imports}

The production and proven reserves of natural gas in Chile are not significant. Since 2010, Chile has depended on gas imports to meet at least 75\% of its demand (Bernal 2018; U.S. EIA 2019b). In $2018,67 \%$ of gas consumption in Chile was met with LNG imports from Trinidad and Tobago, the United States and Equatorial Guinea (International Gas Union 2019; BP 2019). However, in December of 2018, 48\% of Chilean gas imports came from Argentina, just weeks after the two countries resumed trading gas after a 12-year pause caused by Argentina's instability as a gas exporter, as explained above. In the first five months of 2019, the pace of imports from Argentina continued with an average of $39 \%$ of total imports. That percentage is expected to fall during the Austral winter when consumption in Argentina peaks (O'Ryan and Orellana 2019; Asencio 2018; Paraskova 2018).

\subsubsection{LNG Exports}

Peru and Argentina are the only two LNG-exporting countries in South America. Peru was the first country in South America to build a liquefaction facility - the Melchorita plant which began operations in 2010. In 2014, Peru produced $12.6 \mathrm{bcm}$ of natural gas, consumed $7.2 \mathrm{bcm}$ and exported $5.7 \mathrm{bcm}$ of LNG (World Energy Council 2019). Argentina commissioned the first FLNG facility in the Americas in 2019 (Snyder 2019). 


\section{Summary}

While imports of LNG by Argentina, Brazil, and Chile - the three countries in South America that import the most LNG-have declined 36\% from their peak in 2014, the relative accessibility to this form of natural gas will likely continue to make it a desirable fuel source for power generation in the immediate future. LNG's supply flexibility could continue to provide a reliable option for Argentina's seasonal demand while it develops Vaca Muerta. LNG's supply diversity is attractive to Chile, after the country suffered important economic losses during Argentina's crisis of 2001. LNG offers a way for Brazil and Colombia to quickly ramp up natural gas imports during unpredictable drought periods that may last for more than one year. Both countries have significant natural gas reserves and LNG can provide a bridge until such reserves hit the market. It remains to be seen what the long-term role of LNG in the region will be, given the decarbonization pledges that the different countries have made and the potential to develop domestic natural gas resources.

Sections 4-7 now address more country-specific issues and options for Argentina, Brazil, Chile, and Colombia, respectively.

\section{References for Section 3}

Alsema, Adriaan. 2009. "Ecopetrol and Chevron Reduce Gas Exports to Venezuela." Colombia News | Colombia Reports (blog). November 6. https://colombiareports.com/ecopetrol-andchevron-reduce-gas-exports-to-venezuela/.

Argus Media. 2019. “Petrobras Expects Bolivian Gas for 2-4 Yrs More.” March 26. https://www.argusmedia.com/en/news/1872977-petrobras-expects-bolivian-gas-for-24-yrs-more.

Asencio, Sebastián. 2018. “Tras 10 Años: Chile Reinicia Importación de Gas Natural Desde Argentina Para Generar Electricidad.” BioBioChile - La Red de Prensa Más Grande de Chile. October 30. https://www.biobiochile.cl/noticias/nacional/chile/2018/10/30/tras-10-anos-chilereinicia-importacion-de-gas-natural-desde-argentina-para-generar-electricidad.shtml.

Barroso, Luiz Augusto, Hugh Rudnick, Sebastian Mocarquer, Rafael Kelman, and Bernardo Bezerra. 2008. "LNG in South America: The Markets, the Prices and the Security of Supply." https://ieeexplore.ieee.org/document/4596232/.

Bernal, Federico. 2018. “ES correcto comparar energéticamente a Chile con la Argentina?” http://www.oetec.org/nota.php?id=3190\&area=2.

Bnamericas. 2019. "Colombia Sets New Schedule for Pacific LNG Project.” BNamericas.Com. https://www.bnamericas.com/en/news/colombia-sets-new-schedule-for-pacific-lng-project.

BP. 2019. "Statistical Review of World Energy 2019." https://www.bp.com/content/dam/bp/business-sites/en/global/corporate/pdfs/energyeconomics/statistical-review/bp-stats-review-2019-full-report.pdf. 
Chapa, Sergio. 2018. "New Rules at Panama Canal Expected to Boost U.S. LNG Industry." Houston Chronicle. November 30, 2018. https://www.chron.com/business/energy/article/Newrules-at-Panama-Canal-expected-to-boost-U-S-13435551.php.

Deloitte Center for Energy Solutions. 2016. "LNG at the Crossroads, Identifying Key Drivers and Questions for an Industry in Flux." https://www2.deloitte.com/us/en/pages/energy-andresources/articles/lng-industry-trends-oil-natural-gas-report.html.

Diamante, Sofía. 2019. "Vaca Muerta: qué importancia tiene el reservorio en la región." June 2. https://www.lanacion.com.ar/economia/vaca-muerta-la-tecnologia-dinamizo-la-oferta-dereservas-en-el-mundo-y-la-competencia-crecio-nid2253497.

EFE. 2018. "Chile vuelve a importar gas natural de Argentina una década después." EL DEBER. https://www.eldeber.com.bo/economia/Chile-vuelve-a-importar-gas-natural-de-Argentina-unadecada-despues-20181030-8281.html.

Excelerate Energy. 2019. "Bahía Blanca GasPort.” Excelerate Energy (blog).

https://excelerateenergy.com/project/bahia-blanca-gasport/.

Federal Energy Regulatory Commission. 2019. "LNG." https://www.ferc.gov/industries/gas/indus-act/lng.asp.

Finn, Tom. 2017. "Qatar Restarts Development of World's Biggest Gas Field After...” Reuters, April 4. https://www.reuters.com/article/us-qatar-gas-idUSKBN175181.

Furtado, Ingrid. 2019. "Number of LNG Tankers Passing through Panama Canal in 2018 up 77\% on Year: Canal Authority.” S\&P Global Platts May 2.

https://www.spglobal.com/platts/en/market-insights/latest-news/natural-gas/050219-number-of$\underline{\text { lng-tankers-passing-through-panama-canal-in-2018-up-77-on-year-canal-authority. }}$

Gallagher, Patrick. 2018. "A Guide to FLNG (Floating Liquefied Natural Gas).” Oil \& Gas IQ. August 24. https://www.oilandgasiq.com/fpso-flng/articles/guide-to-flng.

Gilbert, Jonathan. 2018. "Argentina Plans to Close LNG Importing Facility." https://www.worldoil.com/news/2018/10/17/argentina-plans-to-close-lng-importing-facility.

Harding, Robin, and David Sheppard. 2017. "Financial Times Japan Outlaws Restrictions on Resale of Lng Cargoes.” Financial Times. https:/www.ft.com/content/9245d034-5bd9-11e79bc8-8055f264aa8b.

Honoré, Anouk. 2016. "South American Gas Markets and the Role of LNG." https://www.oxfordenergy.org/wpcms/wp-content/uploads/2016/10/South-American-GasMarkets-and-the-Role-of-LNG-NG-114.pdf.

International Finance Corporation. 2019. “Liquefied Natural Gas Fuels Latin America’s Energy Options."

https://www.ifc.org/wps/wcm/connect/NEWS EXT CONTENT/IFC External Corporate Site/ News+and+Events/News/Impact-Stories/lng-fuels-lac-energy-options. 
International Gas Union. 2018. "2017 World LNG Report."

https://www.igu.org/sites/default/files/node-document-field_file/IGU_LNG_2018_0.pdf.

International Gas Union. 2019. "2018 World LNG Report."

https://www.igu.org/sites/default/files/node-document-field_file/IGU_LNG_2018 0.pdf.

International Hydropower Association. 2019. "South America."

https://www.hydropower.org/country-profiles/south-america.

Japanese Ministry of Economy, Trade and Industry. 2016. “Japan's Energy. 20 Questions to Understand the Current Energy Situation."

https://www.enecho.meti.go.jp/en/category/brochures/pdf/japan_energy_2016.pdf.

La Nación. 2019. "Vaca Muerta: oportunidades y desafíos de la mayor promesa argentina." July 4. https://www.lanacion.com.ar/economia/vaca-muerta-oportunidades-desafios-mayor-promesaargentina-nid2263937.

Lombrana, Laura Millan, Jonathan Gilbert, and Sabrina Valle. 2019. "So Much Gas, So Few Allies Spells Trouble in Populist Nation." https://www.bloomberg.com/news/articles/2019-0205/bolivia-s-populist-leader-is-running-out-of-gas-customers.

Martinez, Ricardo. 2017. "Natural Gas Revolutionizes Colombia's Offshore Potential." Hart Energy. https://www.hartenergy.com/exclusives/natural-gas-revolutionizes-colombias-offshorepotential-29975.

Massachusetts Institute of Technology. 2011. "The Future of Natural Gas." http://energy.mit.edu/wp-content/uploads/2011/06/MITEI-The-Future-of-Natural-Gas.pdf.

Mendoza, Naki. 2018. "Colombia: Buyer or Producer in the Global Gas Market?" https://www.americasquarterly.org/content/colombia-buyer-or-producer-global-gas-market.

Mitrova, Tatiana, and Tim Boersma. 2018. "The Impact of US LNG on Russian Natural Gas Export Policy."

https://energypolicy.columbia.edu/sites/default/files/pictures/Gazprom\%20vs\%20US\%20LNG CGEP_Report 121418_2.pdf.

Miyamoto, Akira, and Chikako Ishiguro. 2018. "The Outlook for Natural Gas and LNG in China in the War against Air Pollution.” https://www.oxfordenergy.org/wpcms/wpcontent/uploads/2018/12/The-Outlook-for-Natural-Gas-and-LNG-in-China-in-the-War-againstAir-Pollution-NG139.pdf.

Mouawad, Jad. 2009. "Estimate Puts Natural Gas Reserves 35\% Higher.” The New York Times, June 17. https://www.nytimes.com/2009/06/18/business/energy-environment/18gas.html.

Natural Resources Canada. 2018. "Canadian LNG Projects." https://www.nrcan.gc.ca/energy/energy-sources-distribution/natural-gas/canadian-lngprojects/5683. 
Organization of the Petroleum Exporting Countries. 2019. "Annual Statistical Bulletin." https://asb.opec.org/.

O’Ryan, Francisca, and Gustavo Orellana. 2019. “A una década de la crisis, compras de gas argentino se acercan a las de GNL.” La Tercera. June 10.

https://www.latercera.com/pulso/noticia/argentina-explica-casi-40-gas-natural-importado-chilelo-va-del-ano/691996/.

Owen, Will. 2019. “Argentina Looks to LNG Exports as Gas Production Rises.” LNG Industry. July 15. https://www.Ingindustry.com/liquid-natural-gas/15072019/argentina-looks-to-lngexports-as-gas-production-rises/.

Paraskova, Tsvetana. 2018. "Is Argentina Producing Too Much Natural Gas?” OilPrice.Com. https://oilprice.com/Energy/Natural-Gas/Is-Argentina-Producing-Too-Much-Natural-Gas.html.

Patzek, Tad W., Frank Male, and Michael Marder. 2013. "Gas Production in the Barnett Shale Obeys a Simple Scaling Theory." Proceedings of the National Academy of Sciences 110 (49): 19731-36. https://doi.org/10.1073/pnas.1313380110.

Pitts, Pietro. 2019. "Colombia Expected to Sharply Increase LNG Imports If Domestic Production Does Not Grow," S\&P Global Platts, May 17.

https://www.spglobal.com/platts/en/market-insights/latest-news/natural-gas/051719-colombiaexpected-to-sharply-increase-lng-imports-if-domestic-production-does-not-grow.

Rogers, Howard. 2018. "The LNG Shipping Forecast: Costs Rebounding, Outlook Uncertain." https://www.oxfordenergy.org/wpcms/wp-content/uploads/2018/02/The-LNG-ShippingForecast-costs-rebounding-outlook-uncertain-Insight-27.pdf.

Snyder, John. 2019. "First FLNG in Americas Makes Argentina LNG Exporter.” Riviera Maritime Media. https://www.rivieramm.com/news-content-hub/news-content-hub/first-flng-inamericas-makes-argentina-lng-exporter-55169.

Stiles, Tamaki. 2016. "Demand for Liquefied Natural Gas in Japan after Fukushima - Leaders In Energy - Leadersinenergy.Org/.” https://leadersinenergy.org/lng-japan/.

Tan, Huileng. 2016. "Natural Gas Crashes as Japan Demand Wanes, Australia Supply Takes Off." CNBC. March 2. https://www.cnbc.com/2016/03/02/natural-gas-crashes-as-japan-demandwanes-australia-supply-takes-off.html.

TiempoSur. 2016. "Importaciones de Gas: El Eje Chile-Shell." https://www.tiemposur.com.ar/nota/109319-importaciones-de-gas el-eje-chile-shell.

Torres Diaz, Carlos. 2018. "Pre-Salt Rich Brazil - Gas Imports? Yes Please." https://www.rystadenergy.com/newsevents/news/press-releases/Pre-salt-rich-Brazil-Gasimports/.

Trabish, Herman K. 2014. “A User's Guide to Natural Gas Power Plants.” Utility Dive. https://www.utilitydive.com/news/a-users-guide-to-natural-gas-power-plants/259104/. 
Tsukimori, Osamu. 2017. "Tokyo Gas Will Not Accept Destination Clauses in New LNG Contracts.” Reuters, October 5. https://www.reuters.com/article/japan-tokyo-gasidUSL4N1MG0O1.

Ulmer, Alexandra. 2015. "Venezuela's PDVSA Says Halting Colombia Gas Imports." Reuters, June 11. https://www.reuters.com/article/venezuela-colombia-gas-idUSL1N0YX2GM20150611.

U.S. EIA. 2013. "Technically Recoverable Shale Oil and Shale Gas Resources: An Assessment of 137 Shale Formations in 41 Countries Outside the United States."

https://www.eia.gov/analysis/studies/worldshalegas/pdf/fullreport.pdf.

U.S. EIA. 2017. “Argentina.” https://www.eia.gov/beta/international/analysis.php?iso=ARG.

U.S. EIA. 2019a. "Background Reference: Brazil."

https://www.eia.gov/beta/international/analysis_includes/countries_long/Brazil/background2.htm

U.S. EIA. 2019b. "Chile - International."

https://www.eia.gov/beta/international/country.php?iso=CHL.

U.S. EIA. 2019c. "Panama Canal Expansion Allows More Transits of Propane and Other Hydrocarbon Gas Liquids." https://www.eia.gov/todayinenergy/detail.php?id=39272.

U.S. EIA. 2019d. "U.S. Natural Gas Production Hit a New Record High in 2018." https://www.eia.gov/todayinenergy/detail.php?id=38692.

Vinter, Graham, Jeremy Wilson, and William Park. 2018. "European Commission Launches New Antitrust Investigation into LNG Destination Clauses." Inside Energy \& Environment. June 26. https://www.insideenergyandenvironment.com/2018/06/european-commission-launchesnew-antitrust-investigation-into-lng-destination-clauses/.

Waisberg, Idel. 2011. "Brazil's Pre-Salt Layer." http://large.stanford.edu/courses/2011/ph240/waisberg1/.

World Energy Council. 2019. "Peru, Natural Gas."

https://www.worldenergy.org/data/resources/country/peru/gas/.

Zborowski, Matt. 2018. "How Does Vaca Muerta Stack Up vs. US Shale? Data Tell the Tale." https://www.spe.org/en/jpt/jpt-article-detail/?art=4918. 


\section{Argentina}

\subsection{Electricity Sector Overview}

Argentina is the second largest electricity producer and consumer in South America after Brazil. In the last thirty years, the Argentine electricity sector has undergone profound changes, mainly driven by political and economic factors, which have significantly impacted the country's power system flexibility. This section provides an overview of the Argentine electricity sector, briefly describing its history, organization, and development.

\subsubsection{Market Liberalization and Privatization}

Until the early 1990s, Argentina's electricity sector was state-owned, and electricity generation, transmission, and distribution were vertically integrated. In 1992 under President Carlos Menem, the Electricity Regulatory Law No. 24,065 was created to foster increased competition and private investment in the power sector, catapulting Argentina to become one of the first developing countries to liberalize the sector. Law 24,065 also established the basis for the creation of the National Electricity Regulatory Entity (ENRE) to regulate the electricity sector, and the Argentinian Wholesale Power Market Administrative Company (CAMMESA) to perform generation dispatch, operate the national power grid, and coordinate the newly created Argentine competitive wholesale electricity market (Pampa Energia 2019).

\subsubsection{The 2001-2002 Crisis and Electricity Subsidy Policies}

A decade later, however, the evolution of the electricity sector reform was undermined by strong government intervention (through subsidies and top-down regulations) in the sector that began with president Eduardo Duhalde (2002-2003) after the 2001-2002 political and economic crisis and persisted even after the economic recovery throughout the two following presidential administrations (2003-2015). The 2001-2002 crisis was marked by deep recession, depreciation of the Argentine peso, large debts, and profound impacts on the electricity and natural gas sectors. In an attempt to mitigate the impacts of high unemployment and poverty rates, and currency devaluation, the government subsidized consumer prices for privatized public services such as electricity and natural gas. In the electricity sector, prices along with transmission and distribution tariffs (which were originally valued in U.S. dollars) were frozen and fixed in Argentine Pesos. The government also revoked price adjustment provisions and inflation indexation mechanisms (Olave et al. 2015) and introduced a mechanism to calculate the spot electricity prices based only on the price of natural gas (which is regulated by the government), regardless of the fuel and type of generation used. Such measures resulted in distorted electricity pricing, which contributed to an investment collapse in the electricity sector and an unprecedented electricity market structural deficit (Pampa Energia 2019). In particular, electricity companies suffered significant losses due to the decline in revenues with the devaluation of the Argentine peso, leading to huge debts in U.S. dollars and, consequently, delaying needed investments and reducing the quality of service and operating performance of services to consumers (Haselip et al. 2005).

From 2003 to 2015, the Argentine government spent about 51 billion U.S. dollars on power subsidies to keep consumer's electricity bills low (MercoPress 2016). Figure 15 shows the average residential electricity rate in some South American countries in 1996 and 2009, respectively. While most countries experienced an increase in residential rates, Argentina 
experienced a residential reduction of nearly $67 \%$ over the same period. This led to a considerable demand growth in the residential sector that rapidly reduced the country's capacity and reserve margin.

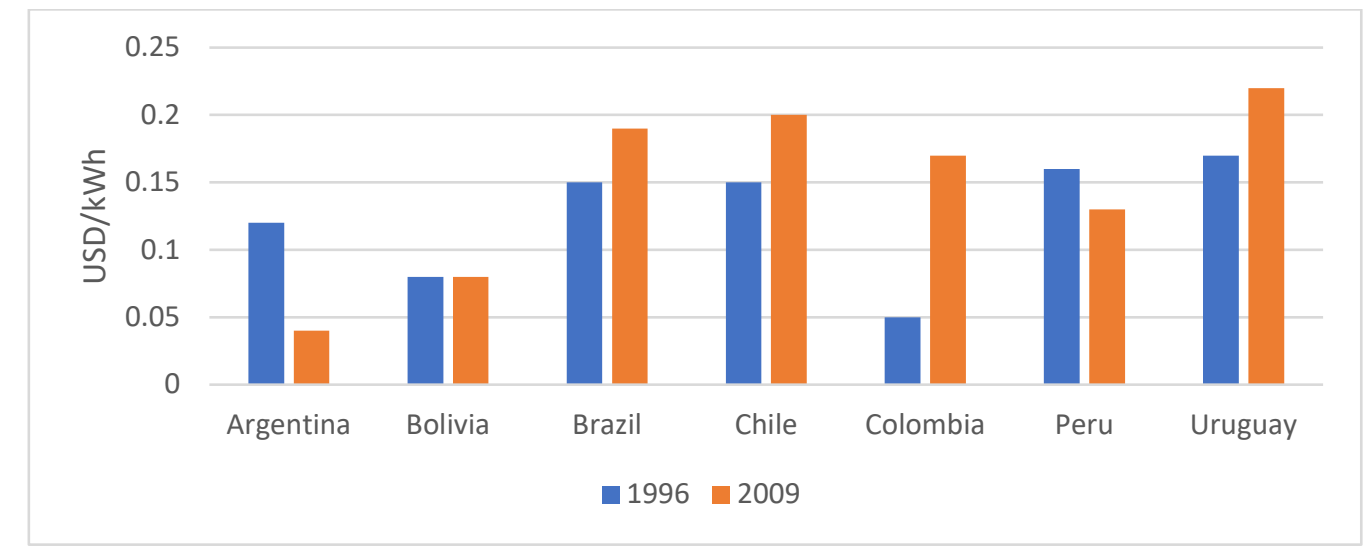

Source: Data from CAF (2011)

Figure 15. Average residential electricity prices in South American countries ${ }^{4}$

\subsubsection{Efforts to Increase Generation Capacity and Flexibility until 2015}

Some of the government initiatives to respond to the electricity demand growth and generation shortage during President Cristina Kirchner's administration include the 'Energy Plus' program, the National Program for the Rational and Efficient Use of Energy (PRONUREE), and Resolution No. 95/2013. The 'Energy Plus' program was implemented in 2006 restricting the electricity traded in the spot market to cover only the demand of regulated consumers. Through this program, a new competitive market ('Energy Plus market') was created for large consumers to cover the electricity demand exceeding their base demand (Mastropietro et al. 2016). This program sought to guarantee supply of regulated consumers and encourage flexibility through self-production of electricity in the industrial sector (International Business Publications 2015). In 2007, PRONUREE was launched to promote energy efficiency on the demand side and contain the demand growth that resulted from government subsidies. Through Resolution No. 95/2013, the hitherto competitive electricity market started to be fully controlled by CAMMESA. Under this resolution, free bilateral trading was suspended, and the single-buyer model was reenacted, thus leading producers and consumers to sell and buy electricity directly to and from CAMMESA, which also became the sole fuel supplier for the power plants participating in the wholesale electricity market.

\subsubsection{The Electricity Sector After 2015}

President Mauricio Macri took office in December of 2015 with the promise to liberalize the economy and normalize the electricity and natural gas markets by gradually cutting subsidies and addressing price distortions without social disturbance (CLAS, 2018). Within a week of taking office, the government declared an "Energy Emergency" until December 2017 through

${ }^{4}$ Different from Argentina, Colombia has a cross-subsidy program for retail electricity customers based on socioeconomic and geographical strata (see Section 7). The average residential electricity prices in Colombia shown in Figure 15 consider the rates for all strata. 
Presidential Decree No. 134/2015 to avoid what it considered to be a possible 'system collapse' and raise awareness of energy efficiency and conservation (AAIP 2015). In 2016, the government announced the planned reduction of electricity subsidies until 2019, as illustrated in Figure 16.

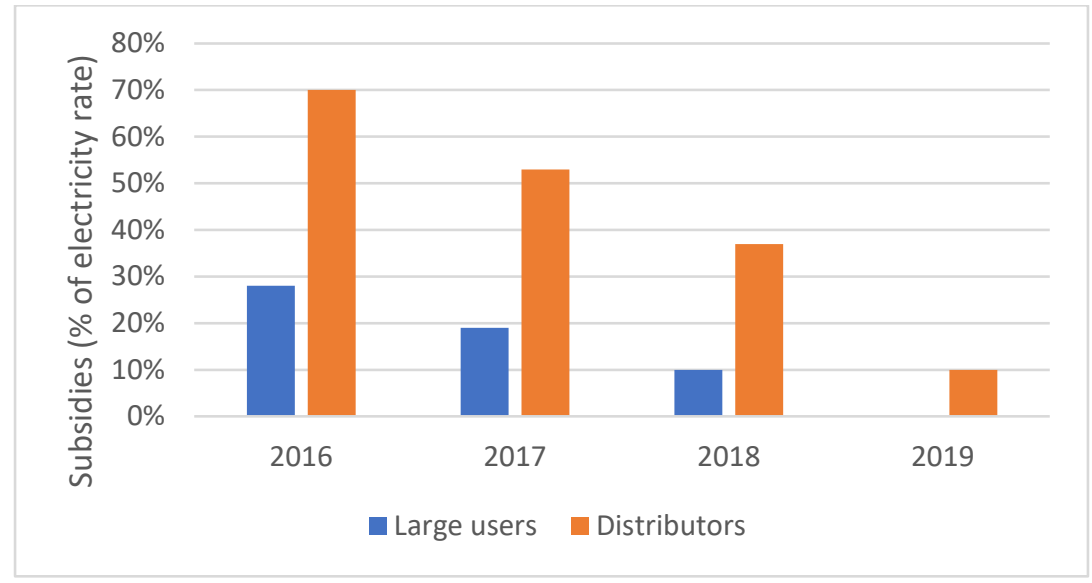

Source: Data from Ganem (2018)

Figure 16. Gradual reduction of electricity subsidies from 2016 to $2019^{5}$

Other recent public initiatives in the electricity sector include international public tenders to attract private investments in the expansion of the country's installed capacity (especially with renewable sources) and the enactment of Resolution 70/2018, which reauthorized power generators, co-generators, and self-generators participating in the wholesale market to freely procure their own fuel for power generation.

\subsubsection{Consumption}

Figure 17 shows Argentina's electricity consumption from 2005 to 2018. In the period of 20052015 , the electricity consumption increased $43 \%$ (mainly led by the residential sector whose consumption increased $76 \%$, followed by the commercial and industrial sectors with consumption growth of $39 \%$ and $15 \%$, respectively) while the country's power generation installed capacity increased only $30 \%$. Following the subsidy reductions on electricity prices and the economic recession, the electricity consumption remained stable from 2015 to 2018, around 133 TWh.

\footnotetext{
${ }^{5}$ Consumers under the Federal Social Rate (special rate designed to protect low-income citizens from rising
} electricity tariffs) are not subject to subsidy reductions (Ganem 2018). 


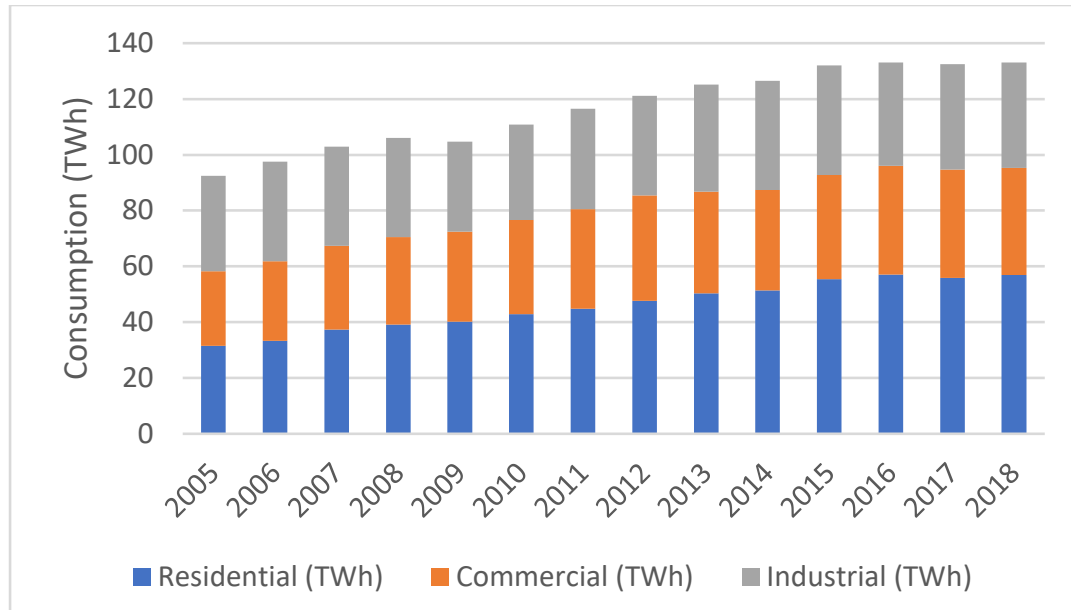

Source: Data from CAMMESA (2019)

Figure 17. Argentina's electricity consumption by sector

\subsubsection{Generation}

\subsubsection{Hydropower and Thermal Power Generation}

Argentina is well endowed with hydropower resources. However, the country has tapped only about $25 \%$ of its hydropower potential (IAE 2015). Before the 2001-2002 crisis, hydropower plants accounted for $40 \%$ of Argentina's total power generation installed capacity. However, their high initial investment costs combined with high inflation rates, currency fluctuations, and socioenvironmental issues led the country to expand its generation capacity primarily with thermal power plants. Figure 18 shows the total and regional installed capacity in Argentina in 2001 and 2018, respectively. From 2001 to 2018, the hydropower installed capacity increased approximately $20 \%$ whereas the thermal power capacity increased nearly $80 \%$ in the same period. Figure 19 shows the evolution of Argentina's electricity generation mix in the same period. As can be seen, hydropower generation remained relatively constant whereas thermal power generation (especially from natural gas) has increased significantly. It is also possible to observe the higher, but still modest, participation of VRE, especially from 2017 onward. 


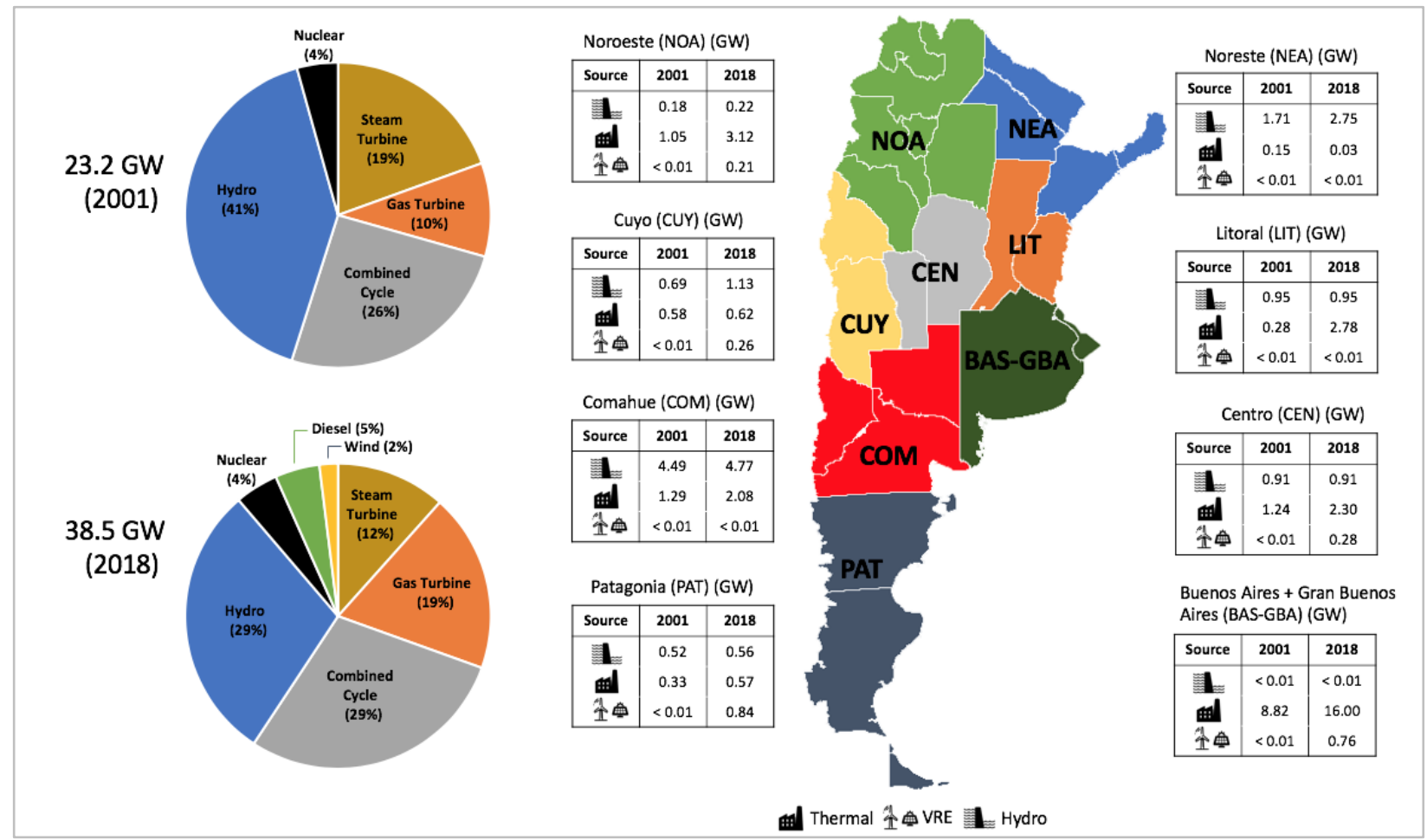

Source: Data from CAMMESA (2019)

Figure 18. Total and regional installed capacity in Argentina in 2001 and 2018

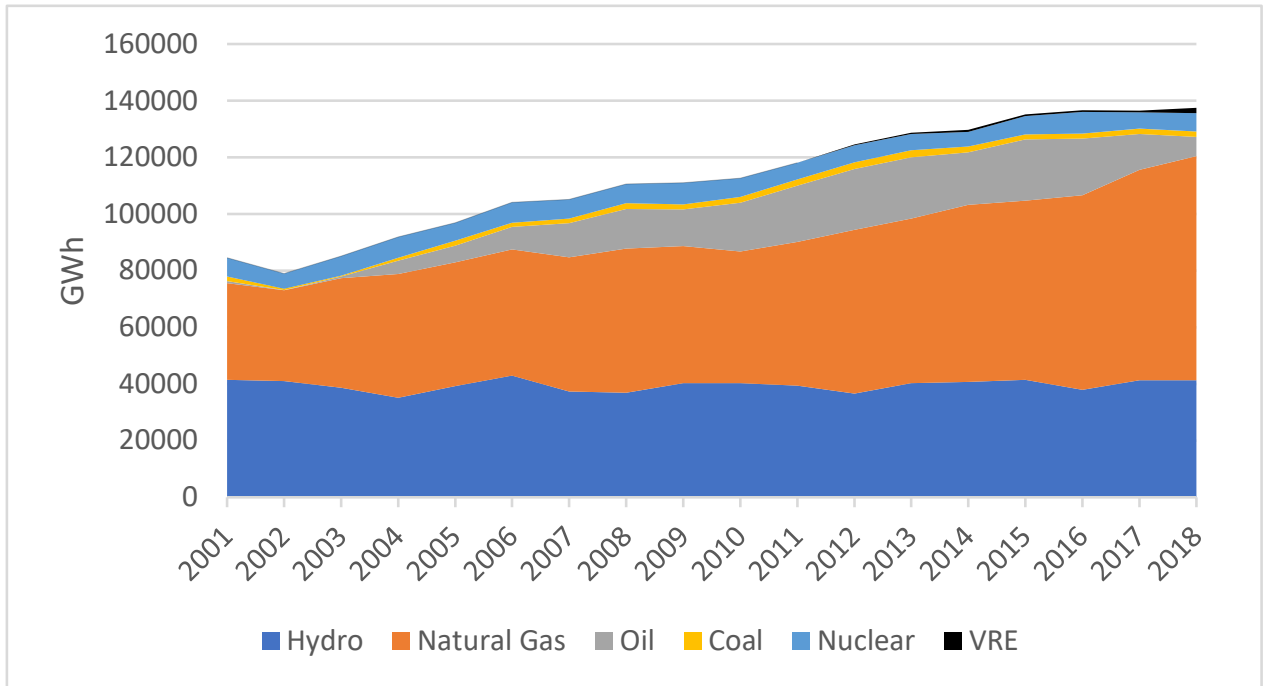

Source: Data from CAMMESA (2019)

Figure 19. Electricity generation mix in Argentina from 2000 to 2018

Some of the thermal power plants in Argentina can operate with different fuels including coal, oil, and natural gas, depending on their availability and price. With the natural gas shortages following the 2004 gas crisis (see Section 4.2.2), liquid fuels such as gasoil and fuel oil made up an increasing share of Argentina's thermal power generation until the mid-2010s, as shown in 
Figure 20. The recent increase in domestic natural gas production has significantly reduced the dependency on liquid fuels for power generation in the past few years.

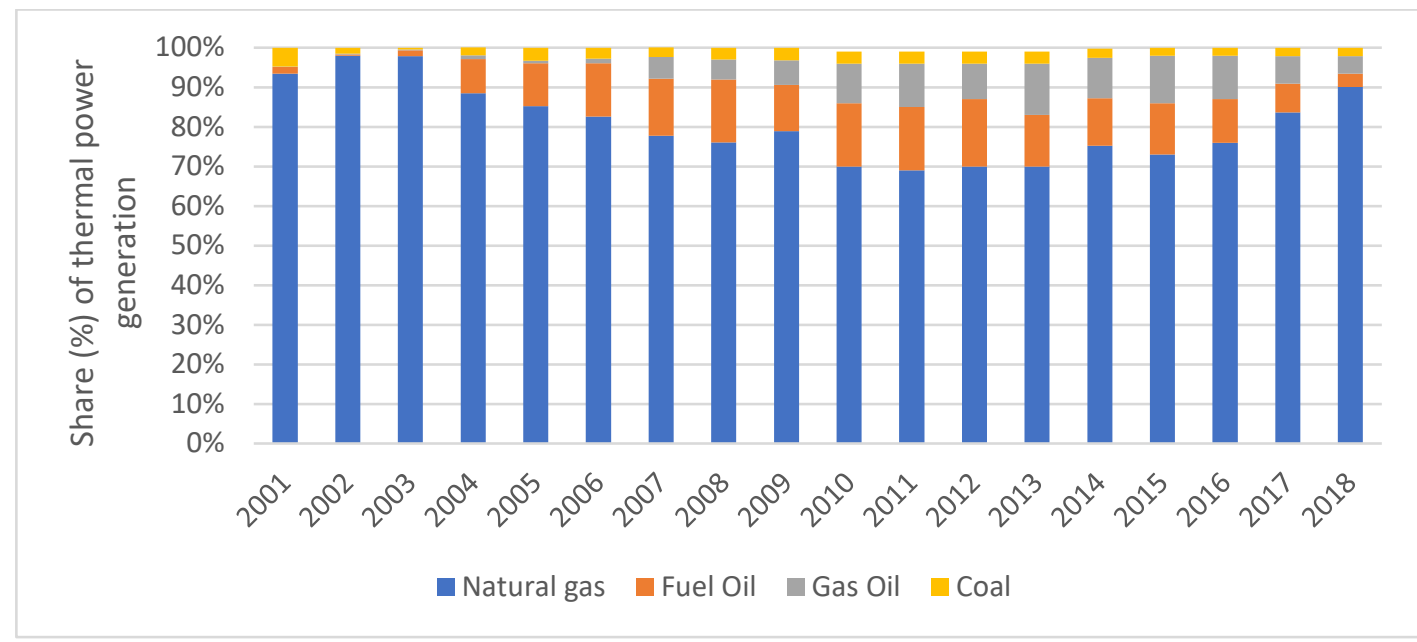

Source: Data from CAMMESA (2019)

Figure 20. Share of Argentina's thermal power generation by fuel

\subsubsection{VRE}

Argentina is also richly endowed with renewable resources. The country has abundant wind power potential, especially in the Patagonia region which has one of the richest wind resources in the world. In addition, there is abundant solar energy potential, especially in the Northwest and Cuyo regions which have high solar irradiance levels. However, the enormous renewable energy potential in Argentina remains largely untapped (Yaneva et al. 2018) due to the lack of effective mechanisms to attract investments to the sector, however that may now be changing.

The first legal instrument for the promotion of renewable energy in Argentina was established in 1998 through Law 25019/1998 (National Wind and Solar Energy Rules) which declared wind and solar power generation of national interest and introduced a feed-in tariff mechanism with tax credits for renewable energy sources. Such mechanism, however, did not offer sufficient incentives to attract significant investments in wind and solar power projects (International Business Publications 2015). In 2007, the government enacted Law 26190 which introduced new incentives (tax benefits, subsidized tariffs, etc.) not only for wind and solar power, but also for other renewable energy sources such as small hydropower, geothermal, and biomass with the objective of increasing the electricity consumption from renewable energy to $8 \%$ in 10 years (by 2017). However, despite offering additional and more attractive incentives, Law 26190 shared many of the same limitations that undermined its predecessor (Law 25019/1998) and did not result in substantial investments in the sector (LaMarca 2011). For example, the Renewable Energy Generation Program (GENREN) was an auction effort launched by the government in 2009 seeking to contract $1 \mathrm{GW}$ of renewable energy projects. However, only around $15 \%$ of the $895 \mathrm{MW}$ awarded got constructed as the country risk was too high and developers had struggled to obtain financing (Yaneva et al. 2018). About six years later, Law 27191/2015 was enacted to expand the tax benefits of Law 26190 and introduce new incentives, such as accelerated depreciation on income taxes and import duty exemptions, to encourage investments in renewable energy projects. It also set the goal of covering $20 \%$ of the total electricity 
consumption with renewable energy sources (excluding large hydropower plants) by 2025. In order to make it viable, the same law also introduced the Trust Fund for Renewable Energy (FODER) run by the country's Investment and Foreign Trade Bank (BICE), aimed to provide, among other things, capital contributions and payment guarantees to facilitate the financing of renewable energy projects.

The launching of the RenovAr program in 2016 was the turning point for Argentina in becoming one of the most promising markets for renewable energy in Latin America. RenovAr tendering mechanisms are comprised of a mix of incentives and guarantees for renewable energy projects where the awarded contracts take the form of long-term power purchase agreements (PPAs) administered by CAMMESA. The RenovAr auctions 1.0, 1.5, 2, and 3 have so far drawn strong investor interest. They already contracted more than $4 \mathrm{GW}$ of renewable power through four heavily oversubscribed auctions. As shown in Table 4, wind and solar power account for nearly $95 \%$ of the contracted capacity. In addition, the prices of the awarded projects with these technologies have decreased significantly, except for the round 3, which targeted smaller-scale projects connected to medium- and low-voltage networks (Renewables Now 2019). Text Box 3 describes the main reasons for the success of the RenovAr program.

In 2017, the Renewable Future Market (MATER) was launched by the government through Resolution 281/2017, allowing large consumers and renewable energy producers to sign freely negotiated private PPAs. The success of this market, however, will depend on attractive financing options for new renewable energy projects.

Table 4. RenovAr's Awarded Capacity and Price by Technology

\begin{tabular}{|c|c|c|c|c|c|c|c|c|}
\hline & \multicolumn{2}{|c|}{ Round 1.0} & \multicolumn{2}{|c|}{ Round 1.5} & \multicolumn{2}{|c|}{ Round 2} & \multicolumn{2}{|c|}{ Round 3} \\
\hline Technology & $\begin{array}{c}\text { Capacity } \\
\text { (MW) }\end{array}$ & $\begin{array}{c}\text { Price } \\
\text { (USD/MWh) }\end{array}$ & $\begin{array}{c}\text { Capacity } \\
\text { (MW) }\end{array}$ & $\begin{array}{c}\text { Price } \\
\text { (USD/MWh) }\end{array}$ & $\begin{array}{c}\text { Capacity } \\
\text { (MW) }\end{array}$ & $\begin{array}{c}\text { Price } \\
\text { (USD/MWh) }\end{array}$ & $\begin{array}{l}\text { Capacity } \\
\text { (MW) }\end{array}$ & $\begin{array}{c}\text { Price } \\
\text { (USD/MWh) }\end{array}$ \\
\hline Wind & 707 & 59 & 765 & 53.34 & 665 & 41.2 & 128.7 & 58.04 \\
\hline Solar & 400 & 59.75 & 516 & 53.34 & 556.8 & 43.5 & 96.75 & 57.58 \\
\hline Biomass & 15 & 110 & - & - & 117.2 & 106.70 & 8.5 & 106.15 \\
\hline $\begin{array}{l}\text { Small } \\
\text { Hydro }\end{array}$ & 11 & 105 & - & - & 20.8 & 98.9 & 7.38 & 103.44 \\
\hline Biogas & 9 & 154 & - & - & 35 & 156.80 & 12.75 & 158.57 \\
\hline $\begin{array}{l}\text { Landfill } \\
\text { Biogas }\end{array}$ & - & - & - & - & 13.1 & 129.2 & 5 & 129.5 \\
\hline
\end{tabular}

Source: Data from Yaneva et. al (2018) and Renewables Now (2019) 


\section{Text Box 3. What Has Made RenovAr Successful?}

Unlike previous efforts to facilitate greater integration of renewable energy in Argentina's energy mix and attract private investments in the sector, RenovAr program has been standing out for its attractive incentives along with a simple, efficient, and transparent auctioning process (PWC 2017). The prices of the long-term PPAs are denominated in U.S. dollars (to avoid exposure to fluctuations of the Argentina peso) and adjusted annually based on the efficiency gains and cost increases (FIEL 2017). In terms of guarantees, FODER trust fund provides two types of guarantees for RenovAr projects - a liquidity guarantee, designed to ensure the payments of the electricity delivered to the grid, and a solvency guarantee, which works as a put option to reduce the country risk (Yaneva et al. 2018). In addition, the FODER fund is backed by more than US\$700 million in additional guarantees from the International Bank for Reconstruction and Development (IBRD), which is a member of the World Bank Group, in case the government fails to provide the funds for project companies that exercise the put option. Figure 21 shows the origin of the awarded RenovAr 1.0, 1.5, and 2 bidders with and without the IBRD guarantee.

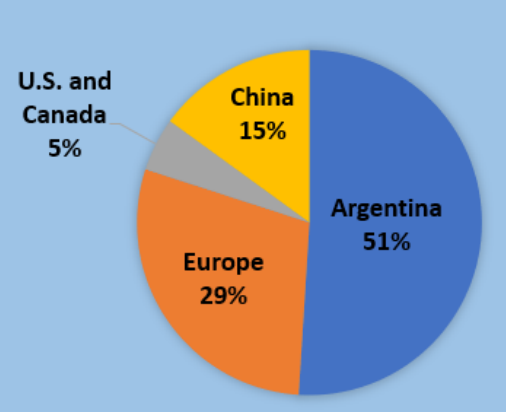

With IBRD Guarantee

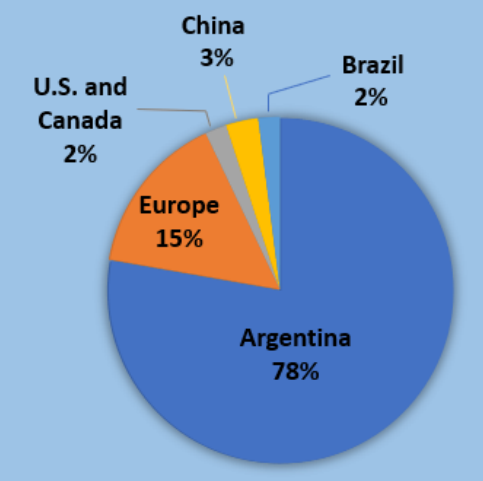

Without IBRD Guarantee

Source: Adapted from Yaneva et. al (2018)

Figure 21. RenovAr (Rounds 1.0, 1.5, and 2) awarded bidders by country of origin

\subsubsection{Transmission Infrastructure}

Argentina has more than 20,000 miles of transmission lines that deliver power to all regions of the country and interconnections with Brazil, Chile, Paraguay, and Uruguay. However, there has been an increasing concern regarding the reliability of the Argentine power system. In the last ten years, some regions have been suffering from frequent electricity outages, mainly due to the deteriorated condition of their power grid which operate at near capacity as the investments in generation, transmission, and distribution capacity have not increased at the same pace of that of electricity demand (Yaneva et al. 2018). In the Buenos Aires Metropolitan region, which accounts for nearly $40 \%$ of Argentina's electricity consumption, outages are common in summer months as the electricity demand spikes with temperatures. After several power outages that struck Buenos Aires and surrounding areas in the midst of a heat wave in the 2015-2016 summer, the government launched a call for tenders for new thermal power generation, where 
some of the awarded projects were committed to start operating in the 2016-2017 summer (Pampa Energia 2019). Another event that exposed the vulnerability of Argentina's electricity infrastructure was the massive blackout of June 2019, as described in Text Box 4.

\section{Text Box 4. June 2019 Blackout}

On 16 June 2019, a massive blackout hit Argentina, Uruguay, and parts of Paraguay, leaving tens of millions without electricity for several hours. According to preliminary reports (Secretaría de Energia, 2019a), the problem possibly started with a short-circuit that disconnected a 500-kV transmission line between the provinces of Buenos Aires and Entre Rios in Argentina. Then, due to failures in the protection system, other lines were disconnected leading to what the Argentina Secretariat of Energy called "a collapse of the Argentine Interconnection System (SADI)" (Nordrum, 2019).

\subsection{Natural Gas Sector Overview}

Argentina is the largest producer and consumer of natural gas in South America and has the potential to be among the world's top gas markets in the future. This section provides a brief overview of the history, organization, and development of the natural gas sector in Argentina.

\subsubsection{Liberalization and Privatization Policies in the early 1990's}

The natural gas sector in Argentina has a very similar history to that of the electricity sector, at least over the last 30 years. The market liberalization and privatization policies in the early 1990 's attracted many investments to the sector. Among the state-owned companies that were privatized in that period was YPF, one of the world's first entirely state-owned oil and gas companies, which was founded in 1922. With the new investments in the gas sector, domestic production rapidly overtook demand and, as a consequence, Argentina started to export natural gas to some of its neighboring countries such as Chile, Uruguay, and Brazil (Oxford Institute for Energy Studies 2016). In particular, Chile became a key importer of natural gas from Argentina and several pipelines were built between the two countries.

\subsubsection{The 2004 Gas Crisis}

With the government subsidies on natural gas during and after the economic crisis of 2001-2002, the country suffered from lower investments in natural gas exploration and production and increasing demand. The situation worsened in 2004 with the so called '2004 gas crisis' as domestic production was insufficient to meet demand. The government then decided to significantly reduce its natural gas exports in an attempt to limit domestic shortages. Chile, which had become heavily dependent on natural gas imports from Argentina, was severely impacted by the breaches of natural gas contracts. Another government effort to respond to the gas crisis was the creation of the Argentina Energy Anonymous Society (ENARSA) in 2004 (i.e., a majority state-owned company responsible for, among other things, the exploration, production, and commercialization of oil and gas) reinserting the state as a key participant in the sector. 


\subsubsection{Efforts to Increase Domestic Natural Production Until 2015}

Government efforts to boost natural gas exploration and production during Former-President Cristina Kirchner's Administration included the creation of the 'Gas Plus' market in 2008 (i.e., a special market with attractive prices for natural gas from new discoveries and tight formations (International Business Publications, 2015)) and the renationalization of YPF. In 2012, the government claimed that Repsol, a Spanish oil and gas company which was the owner and operator of YPF, had reduced its investments in Argentina which led the country to lose its oil self-sufficiency in 2010. Former-President Cristina Kirchner then introduced a bill to renationalize YPF. The bill was passed by the Congress and signed by Kirchner in the same year.

From 2003 to 2014, the production of oil and natural gas decreased nearly $30 \%$ and $20 \%$, respectively (Secretaría de Energia, 2019b). This was not due to the lack of resources, but rather the lack of investments in the hydrocarbons sector resulting from high subsidies and price distortions (Folgar 2016). In 2014, the Hydrocarbons Law was created, which promoted incentives to attract investments in the production of unconventional hydrocarbons, especially in the Vaca Muerta formation (IEEFA 2019). These efforts, however, were not sufficient to ensure Argentina's self-sufficiency of natural gas so the country used pipeline and LNG imports to fill its consumption gap.

\subsubsection{The Natural Gas Sector After 2015}

Like in the electricity sector, President Macri reduced natural gas subsidies to consumers from 2015 onward, except for those under the Federal Social Rate mechanism for natural gas, which has similar rules to that of electricity. On the production side, a new subsidy mechanism (Gas Plan) was created through Resolution 46/2017 to boost unconventional gas production. The Gas Plan mechanism guarantees minimum prices in U.S. dollars until 2021 for unconventional gas sold in the domestic gas market (FARN 2019).

\subsubsection{Domestic Production}

In 2011, YPF announced a large discovery of shale oil and gas in the Vaca Muerta field (see Text Box 5). The increasing gas exploration from this field has boosted the domestic production in recent years. From 2015 to 2018 , the annual natural gas production increased nearly $10 \%$. In particular, gas from shale and tight formations had significant growth, as shown in Figure 22. 


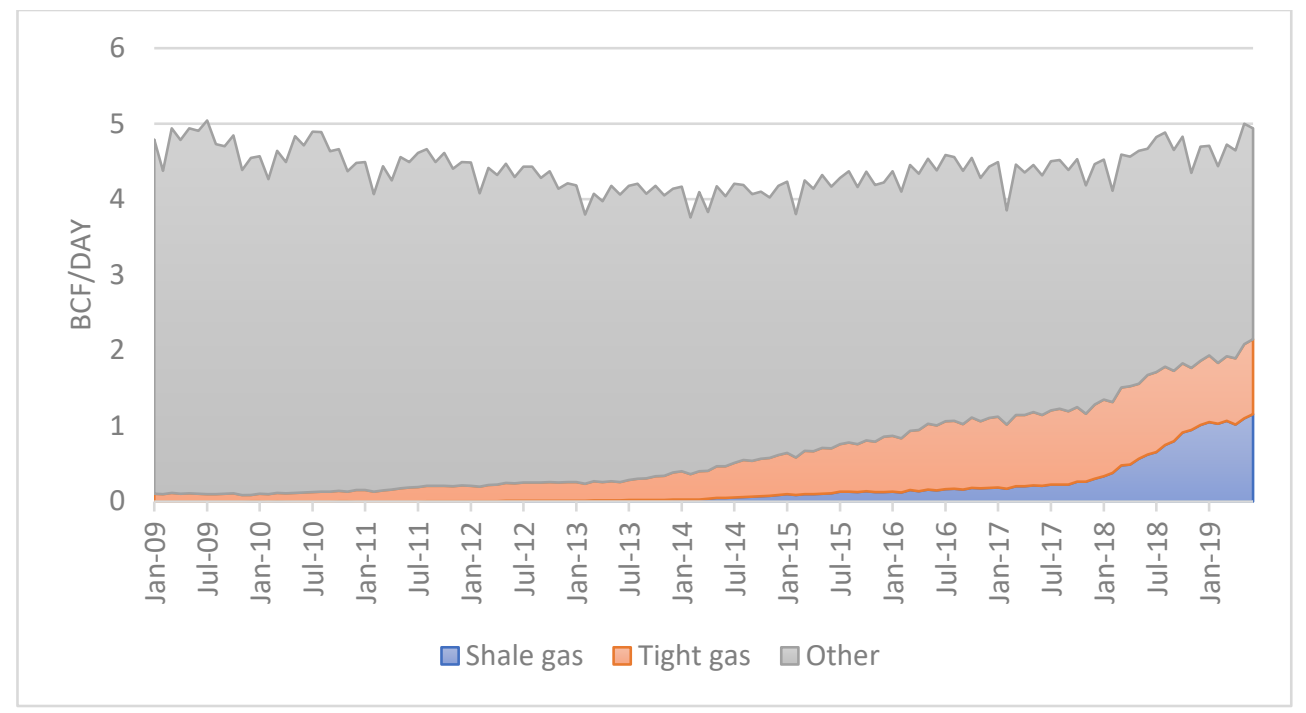

Source: Data from Secretaría de Energia (2019b)

Figure 22. Evolution of Argentina's natural gas production by type

In June of 2019, shale and tight gas accounted for $43 \%$ of the total domestic production, where more than 30\% came from Vaca Muerta, thus offsetting substantial declines from mature fields (U.S. EIA 2019). 


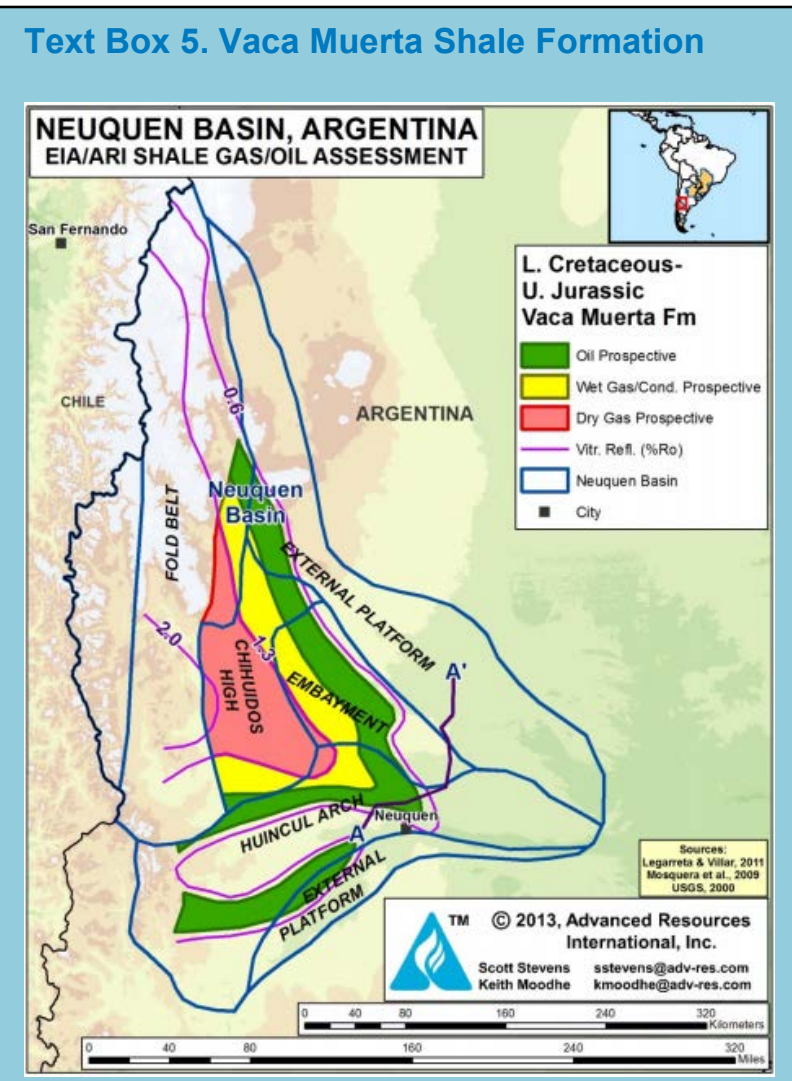

Source: U.S. EIA (2017)

Figure 23. Neuquen Basin in Argentina
The Vaca Muerta shale formation is located in the Neuquen Basin in Northwestern Patagonia region. It covers approximately $12,000 \mathrm{mi} 2$ of the $53,000 \mathrm{mi}^{2}$ of the Neuquen Basin (Oxford Institute for Energy Studies, 2016). Vaca Muerta is estimated to hold the world's second-largest shale gas reserves, with about $300 \mathrm{Tcf}$ of dry, wet, and associated recoverable shale gas resources and 16 billion barrels of oil. Figure 23 shows the regional prospective of each hydrocarbon in the Vaca Muerta region. This basin has similar geologic properties (thickness, pressure, and mineral composition) to the Eagle Ford play in the United States (U.S. EIA 2017).

There are currently more than 40 active oil and gas producers in Vaca Muerta. However, as of July 2019 , only about $4 \%$ of its acreage has entered the development phase (U.S. EIA 2019). The Argentine government estimates that, at full development, Vaca Muerta can accommodate approximately 85,000 wells from which about 1,000 were drilled so far (Secretaría de Energía 2018a).

\subsubsection{Consumption}

Unlike other South American countries, such as Brazil and Colombia, the natural gas demand in Argentina has a strong seasonal pattern, as illustrated in Figure 24. During warmer periods (October through April), domestic production usually exceeds consumption. On the other hand, during winter (May through September), domestic production is insufficient to meet the demand growth (which is mainly driven by residential heating) and, due to the lack of underground storage infrastructure, the country has to shut down surplus production in warmer periods and resort to pipeline and LNG imports. Figure 25 shows the natural gas consumption by sector in the last ten years in Argentina. The most significant growth has been in the power generation sector, mainly due to the government efforts to reduce the dependency on expensive liquid fuels such as fuel oil and gas oil, and the gradual reduction of natural gas subsidies in other sectors. 


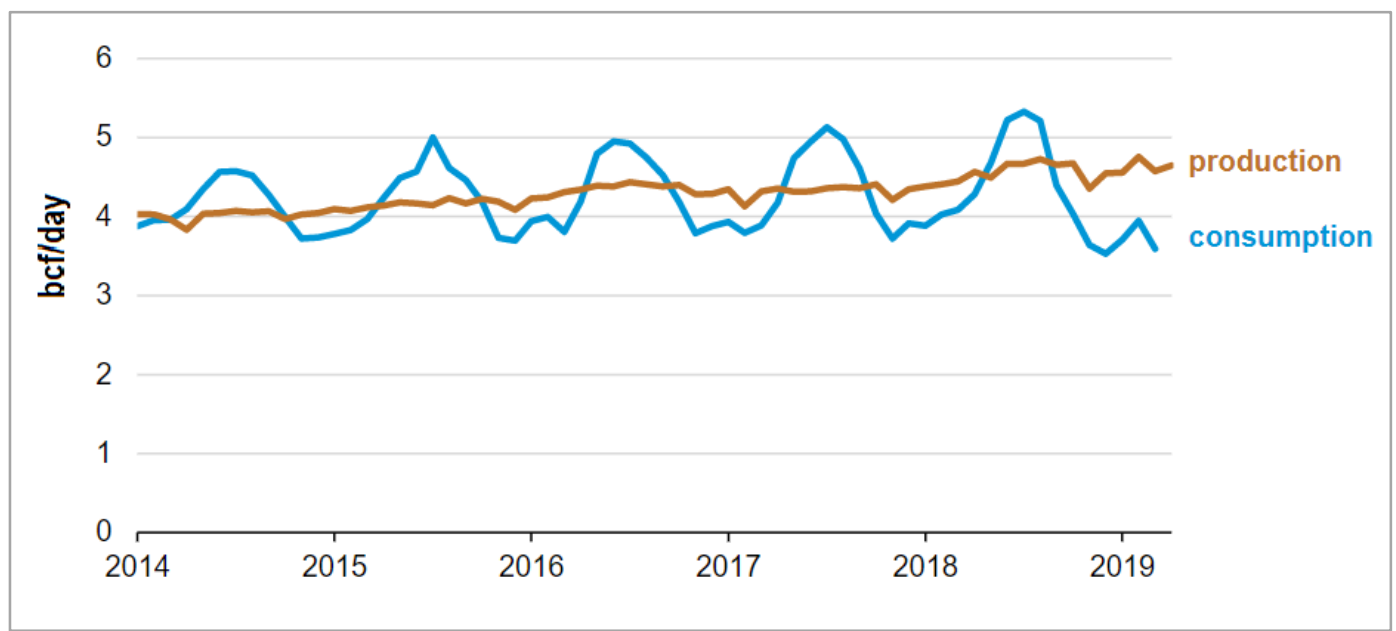

Source: U.S. EIA (2019)

Figure 24. Monthly natural gas production and consumption in Argentina

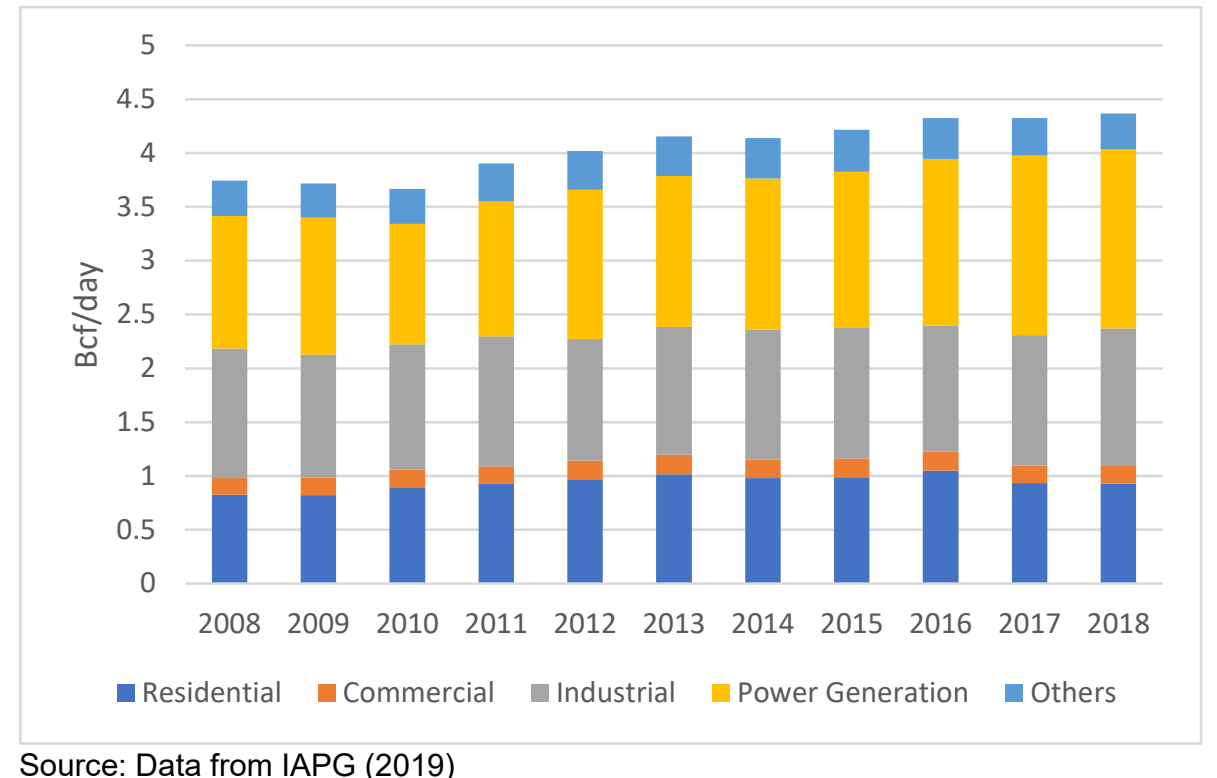

Figure 25. Natural gas consumption by sector from 2008 to 2018 in Argentina

\subsubsection{Imports and Exports}

Argentina's natural gas imports and exports have presented significant variations over the last two decades (Figure 26), which have been mainly driven by domestic production fluctuations and increasing consumption, especially for power generation. 


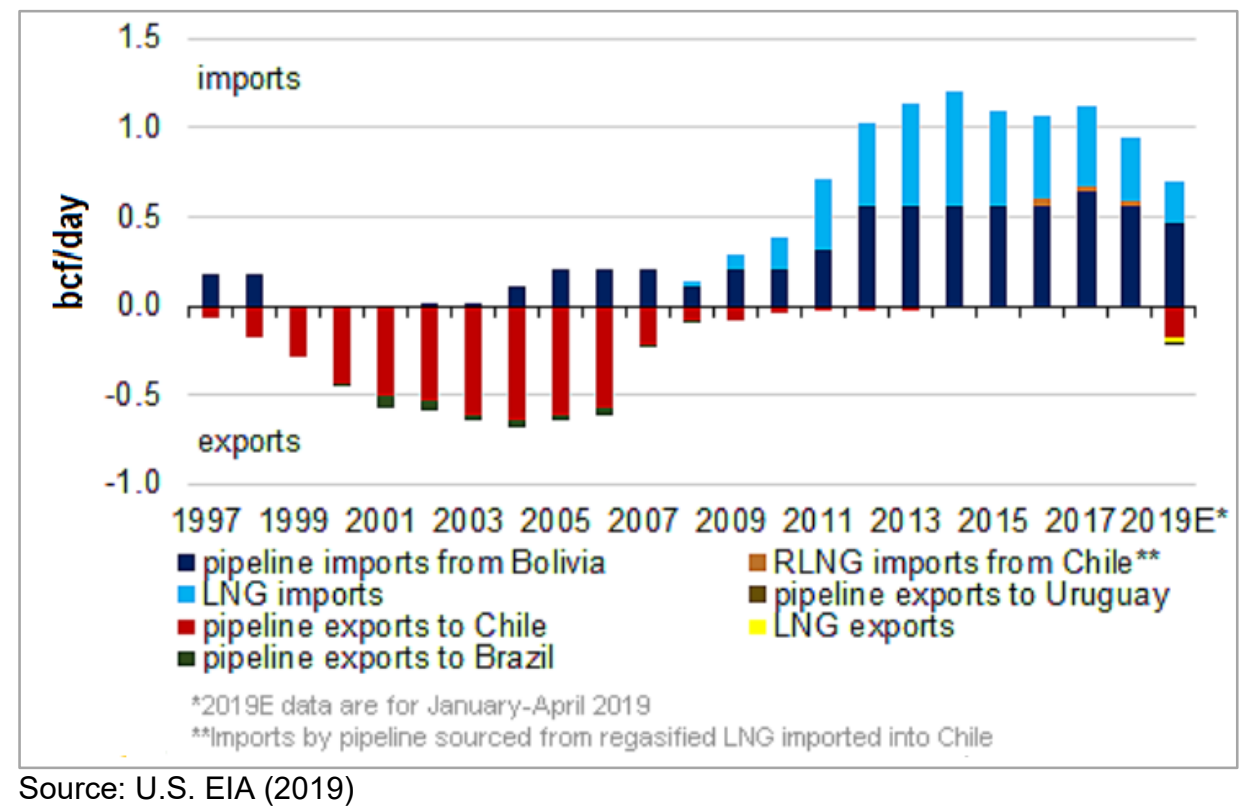

Figure 26. Argentina's natural gas imports and exports

\subsubsection{Pipeline Imports}

After the gas crisis in the mid 2000's, Argentina resumed importing significant amounts of natural gas from Bolivia (which had been stopped in 1998) through the existing YacimientosBolivian Gulf (Yabog) pipeline. However, the pipeline imports are expected to decrease significantly in 2020 as the country expects to increase its domestic production and reduce imports.

\subsubsection{LNG Imports}

In addition to resuming pipeline imports, Argentina also imports LNG (mainly bought on the spot market) to fill its supply gap. The Bahia Blanca FSRU, in the province of Buenos Aires, came online in 2008 as the first LNG regasification terminal in South America. In 2011, the Escobar FSRU, also in the province of Buenos Aires, was inaugurated, thus increasing the country's regasification to $1000 \mathrm{MMscf} / \mathrm{d}$. LNG imports have increased the flexibility of Argentina's natural gas sector and helped the country to mitigate the issues associated with the variations and seasonality of the natural gas consumption. With greater domestic production, LNG imports are also expected to decline. In October of 2018, the Exemplar FSRU departed the LNG terminal of Bahia Blanca after the Argentine government decided not to renew its lease due to its high costs and underutilization, especially in summer months, and the expectation of increasing natural gas production from Vaca Muerta (FARN 2019). Figure 27 shows Argentina's LNG imports by country of origin. The country has imported most of its LNG from Trinidad and Tobago and Qatar. In 2018, however, Argentina imported 21\% of its LNG from the United States, which started exporting LNG to Argentina in 2016. 


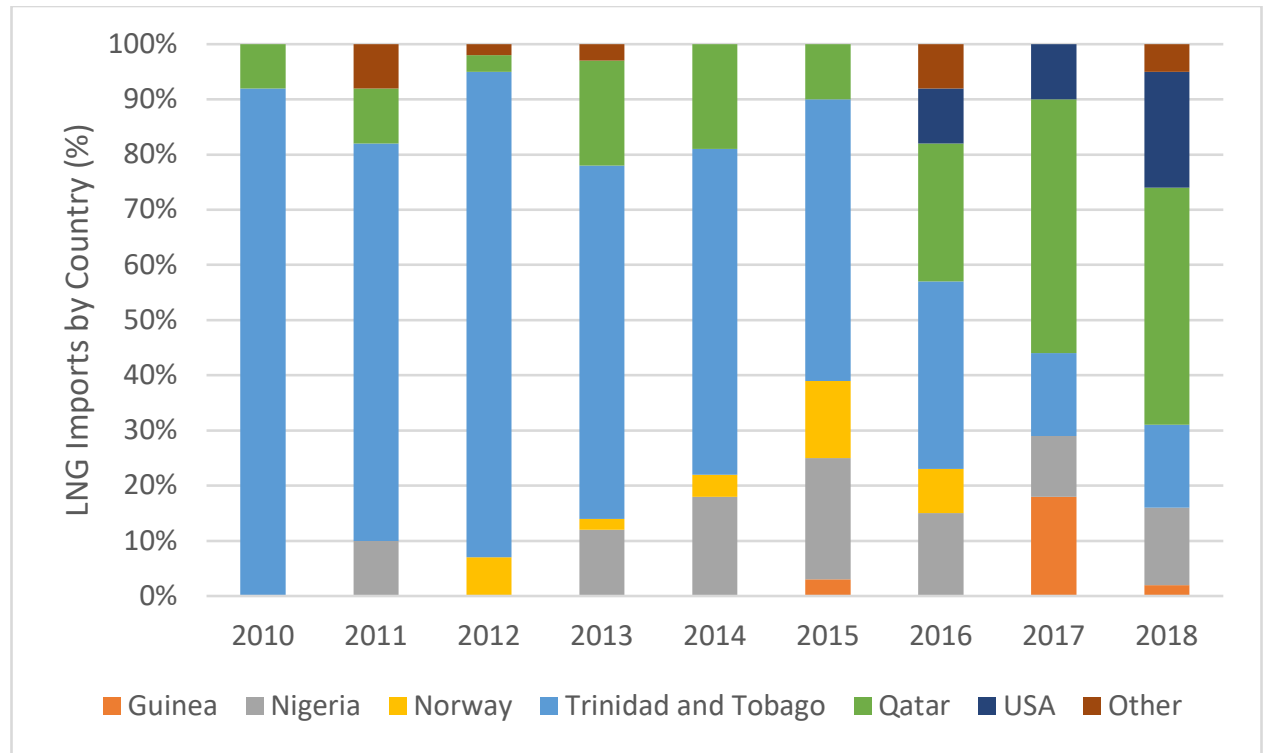

Source: Data from GIIGNL (2019)

Figure 27. Argentina's LNG imports by country of origin

\subsubsection{Exports}

As a result of the increasing production of unconventional natural gas, several measures have been adopted by the Argentine government to monetize the country's gas surplus. Two of the recent measures are described in Text Box 6.

Text Box 6. Recent Measures to Monetize Argentina's Unconventional Natural Gas

\section{Resuming of natural gas exports to Chile}

At the end of 2018, Argentina resumed exporting natural gas by pipeline to Chile after a 12year interlude mainly caused by diplomatic conflicts between the two countries following the Argentine gas crisis in the mid-2000s. The Argentine government authorized gas producers such as YPF and Total to export natural gas to Chile during the eight-month period (OctoberMay) of lower residential demand in Argentina (Reuters 2019).

\section{Argentina becomes an LNG exporter}

Argentina recently joined the group of LNG exporting countries for the first time. In June of 2019, the country shipped its first LNG cargo from the Tango floating liquefaction unit, which has a production capacity of $0.07 \mathrm{Bcf} /$ day and is located in the port of Bahia Blanca. Tango is expected to produce up to eight LNG-export cargoes per year (U.S. EIA 2019). 


\subsection{Power System Flexibility}

\subsubsection{Sources of Flexibility}

The main sources of flexibility in Argentina are impoundment hydropower plants (medium and long-term), run-of-the-river power plants (short-term), and thermal power plants, mostly new gas-fired plants (short, medium, and long-term). Argentina is the only country in South America with significant pumped storage hydropower capacity. The pumped storage hydropower plants of Rio Grande (750 MW) and Los Reyunos (224 MW) account for nearly 10\% of the country's installed hydropower capacity, thus being an important source of flexibility. In addition, the recent integration of wind and solar plants (mainly contracted in the RenoVaR auctions) are helping the country to diversify its generation mix and increase its long-term power system flexibility.

\subsubsection{Drivers of the Need for Flexibility}

\subsubsection{Rainfall Variability}

Since Argentina is in the southern part of the South American continent, its hydropower generation can be significantly reduced during the periods of La Niña. Figure 28 shows how the intense La Niña of 2010-2012 affected the hydropower generation in the Salto Grande dam, which is the country's second-largest hydropower plant, located on the Uruguay river between Concordia, Argentina, and Salto, Uruguay. During such periods, Argentina has to resort to alternative, and possibly very expensive, sources of generation to provide long-term flexibility and meet its electricity demand. For example, a strong La Niña during the wintertime, when there is lower availability of domestic natural gas, may lead the country to use imported liquid fuels such as fuel oil and gas oil which can cost more than three times the price of domestic natural gas.

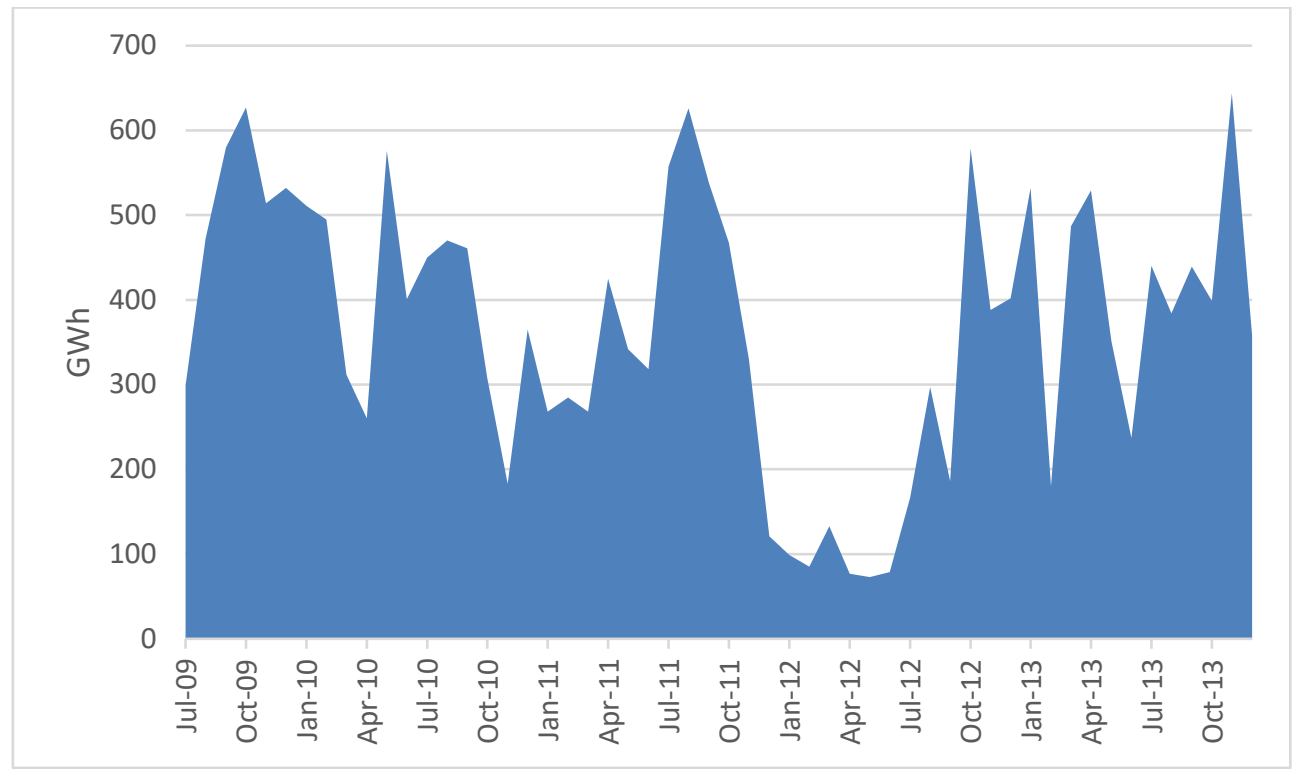

Source: Data from CAMMESA (2019)

Figure 28. Hydropower generation of Salto Grande Dam in Argentina 


\subsubsection{Public Opposition to Hydropower Plants}

Argentina is facing increasing social opposition and stricter environmental laws for new hydropower projects. The country still has a significant untapped hydropower potential, especially in the southern region. However, various socio-environmental along with political and economic instabilities are significant barriers to the future development of impoundment and run-of-the-river hydropower plants in Argentina since investors may opt for projects with lower initial investment costs and environmental impacts.

\subsubsection{Growing VRE Integration}

The increasing penetration of VRE in Argentina has increased the need for power system flexibility at shorter timescales. Figure 29 shows how fast Argentina's VRE installed capacity increased in the last ten years, especially after the first RenoVar auction in 2016. From June of 2017 to June of 2019, the wind power installed capacity increased from 327 MW to 1,071 MW. In the same period, the solar power installed capacity increased from $9 \mathrm{MW}$ to $330 \mathrm{MW}$. The VRE installed capacity in Argentina is expected to keep growing as the country aims to launch new public auctions for renewable energy and attract more private investments to the sector.

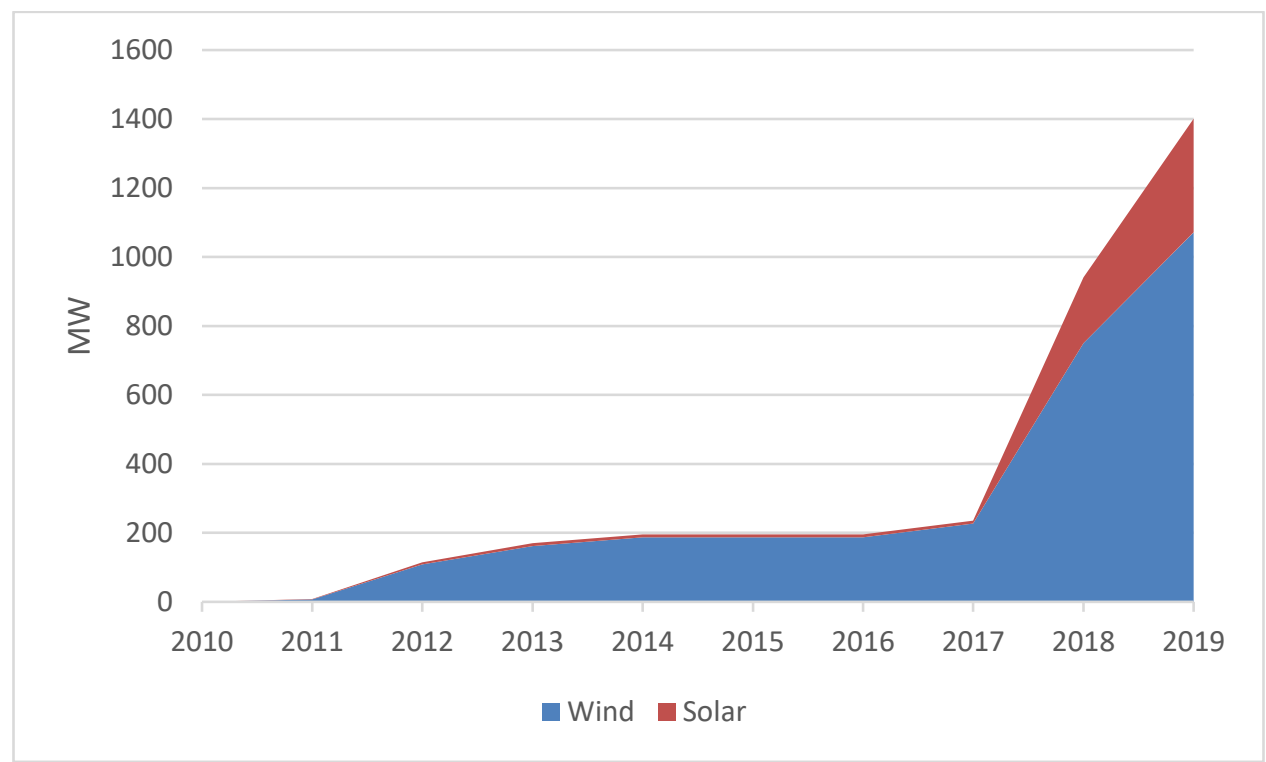

Source: Data from CAMMESA (2019)

Figure 29. VRE installed capacity in Argentina

\subsubsection{Thermal Power Inflexibility and Fuel Supply Uncertainties}

Argentina still has a significant number of old combined cycle power plants which can only provide limited or costly flexibility services. The country is expected to significantly increase its domestic natural gas production over the next years. However, future production, and consequently imports and exports, are still uncertain due to various technical challenges to be addressed along with political, and economic uncertainties that are expected to persist and affect the flexibility of supply at least in the short term. 


\subsection{Key Policy Options to Enhance Flexibility in Argentina}

Various policy options exist in both electricity and natural gas sectors to ensure Argentina's power system flexibility and reliability, and also to reach the country's short and long-term goals in both sectors. Table 5 shows some of the main goals for the electricity and natural gas sectors described in the Argentina Energy Plan (Secretaría de Energía 2018a).

Table 5. Argentina Energy Plan Goals

\begin{tabular}{|c|c|c|}
\hline Sector & Subsector & Goal \\
\hline Electricity & Renewable Energy & $\begin{array}{l}20 \% \text { of the country's electricity } \\
\text { consumption from renewable } \\
\text { energy sources by } 2025 \text {. }\end{array}$ \\
\hline \multirow[b]{3}{*}{ Natural Gas } & Domestic Production & $\begin{array}{l}\text { - Double domestic production in } 5 \\
\text { years and reach 8.4 Bcf/day. }\end{array}$ \\
\hline & Imports & $\begin{array}{l}\text { - Stop importing LNG by } 2022 \text {. } \\
\text { - Stop importing pipeline natural } \\
\text { gas by } 2026 \text {. }\end{array}$ \\
\hline & Exports & $\begin{array}{l}\text { - Exports to Chile (Bcf/day): } 1 \text { (by } \\
\text { 2022). } \\
\text { - } \\
\text { Exports to Brazil (Bcf/day): } 0.3 \\
\text { (by 2022), } 1 \text { (by 2025). } \\
\text { - } \quad \text { LNG exports (Bcf/day): } 40 \text { (by } \\
\text { 2023), } 120 \text { (by 2025). } \\
\text { - Be the world's fifth largest LNG } \\
\text { exporter by } 2026 .\end{array}$ \\
\hline
\end{tabular}

Source: Secretaría de Energía (2018a)

\subsubsection{Electricity Sector Policy Options}

Generation Mix Diversification: Argentina has been working to diversify its generation mix, mainly with VRE sources, to enhance its power system flexibility. The country's goal is to have $20 \%$ of the electricity demand covered by renewable energy generation (excluding large hydropower plants) by 2025 . This is a challenging goal given that, in 2018 , only $2.5 \%$ of the country's electricity demand was covered by non-large hydro renewable generation (CAMMESA 2019). However, the already awarded RenovAr projects that will be put into operation in the next few years combined with new RenovAr rounds and additional private investments may help the country to reach this goal. The creation of the MATER market for renewable energy PPAs described in Section 4.1.6.2 represents an important step towards greater private investment in renewable energy in Argentina. However, its success will depend on the availability of international financing and guarantees to protect investors from various risks. Other generation options, such as geothermal, could be further explored to increase the country's generation mix diversification. Argentina has about $1.6 \mathrm{GW}$ of geothermal potential, which remains largely untapped.

\footnotetext{
${ }^{6}$ Excludes large hydropower plants (above $50 \mathrm{MW}$ ).
} 
Demand Side Management: Argentina has a great potential to enhance its flexibility on the demand side. However, the country lacks regulatory mechanisms in both wholesale and retail levels to encourage and properly compensate demand side resources for energy efficiency, and flexibility services. According to Argentina's Energy Scenarios 2030 report (Secretaría de Energía 2018b), additional energy efficiency measures may reduce the need for additional $8 \mathrm{GW}$ of power generation capacity by 2030 .

Storage Systems and Regional Interconnections: Additional investments to expand and upgrade transmission infrastructure are essential to connect future wind and solar projects (which may be located far away from the main consumption centers) to the power grid in a reliable way, and mitigate the uncertainties of VRE sources. In some cases, additional investments in energy storage (other than existing pumped-storage) can further fascilitate integration of these VRE sources in a cost-effective manner.

Distributed Energy Resources (DERs): In addition to utility-scale renewable generation, distributed energy resources (DERs) may play a key future role in Argentina to reduce the dependency on centralized generation units and provide technical services to the grid. The Renewable Energy for Rural Markets Project (PERMER), which provides benefits for DER development in rural communities, is an example of a government initiative towards greater DER integration.

Effective Pricing Mechanisms: In order to address the current flexibility issues, Argentina needs to develop effective regulatory mechanisms designed to encourage a greater emphasis on market efficiency, reliability, and resiliency, across and between different components of its power system (see Section 2), while ensuring revenue sufficiency of market participants. The current subsidy reductions for retail customers, for example, represent an important step toward greater market efficiency.

\subsubsection{Natural Gas Sector Policy Options}

Investments in Domestic Production: The existing political and economic instabilities in Argentina have posed many obstacles and uncertainties for future domestic production. The future of Vaca Muerta shale play, for example, will depend on several factors such as new government incentives as well as private financing options designed to attract national and international investments in many sectors.

Pipeline Infrastructure Expansion and Underground Storage: Future domestic production and exports will also depend on the expansion of the existing transmission capacity, especially from Vaca Muerta to various consumption centers, which are located mainly in Buenos Aires and Littoral provinces ${ }^{7}$. In July of 2019, the Argentine government launched an international tender for the construction of a pipeline from Vaca Muerta to the province of Buenos Aires. This \$2 billion pipeline will stretch over 600 miles and its first stage (from Vaca Murta to Salliqueló) is slated to be completed by 2021 (Bnamericas 2019). Additional pipeline interconnections with

${ }^{7}$ Argentina's Littoral region is located in the far northeast and includes the Mesopotamia region and the provinces of Santa Fe, Formosa, and Chaco. 
neighboring countries, such as Brazil, may also boost domestic production, mitigate supplydemand imbalances, and diversify export markets. However, it will depend on the country's ability to honor current contracts. Argentina is especially committed to rebuilding trust with Chile, after several natural gas-related diplomatic issues between the two countries in the mid2000's.

Another important option that could help Argentina address the issues related to its natural gas demand seasonality is the development of large-scale storage facilities. The country is currently conducting feasibility studies to identify geologically suitable sites for natural gas storage (U.S. EIA, 2019). YPF and Tecpetrol (the two largest producers of unconventional natural gas in Argentina) are working together on a project to store nearly $90 \mathrm{Mcf} /$ day of natural gas from Vaca Muerta in depleted wells in the Los Bastos field, during warmer months (Gianetti et al. 2018).

\section{Robust Market / Import Diversification / Flexible LNG Contracts and Technologies:} Opportunities exist for greater domestic supply and import/export diversification in Argentina. However, it will depend on the country's ability to develop effective and robust pricing mechanisms to stimulate greater competitiveness, lower prices, and improved service quality. LNG imports will still play a big role in Argentina, especially during winter months, until the country finds a way to address the consumption seasonality issues. On the other hand, greater LNG exports will depend on the construction of natural gas liquefaction facilities (floating or land-based) as well as additional transmission infrastructure from production facilities to LNG liquefaction terminals.

\section{Summary}

Argentina has a great potential for modernizing its electricity sector and ensuring greater flexibility and reliability of its power system. In the natural gas sector, the country has an enormous potential to increase its domestic production, reduce and even eliminate imports, and significantly increase its natural gas pipeline and LNG exports in the next years. However, further developments in both sectors will rely on massive investments in infrastructure as well as public policies and strategies aimed at addressing current and future flexibility challenges and needs. 


\section{References for Section 4}

Agencia de Acesso a la Información Pública (AAIP), Decreto 134/2015. Accessed July 2019: http://www.aaip.gob.ar/normativa/nacional/decreto-134-2015-256978/texto

Bnamericas. 2019. “Argentina Launches Tender for Vital Vaca Muerta Gas Lines.” Accessed August 2019: https://www.bnamericas.com/en/news/argentina-launches-tender-for-vital-vacamuerta-gas-line

CAMMESA. 2019. “Informe Anual.” Accessed February 2019:

http://portalweb.cammesa.com/memnet1/Pages/descargas.aspx

Cassandra Garrison, 2019, "Political Turmoil, Price Freeze Cast Shadow on Argentina's Vaca Muerta," Reuters, September 16. https:/wkzo.com/news/articles/2019/sep/16/political-turmoilprice-freeze-cast-shadow-on-argentinas-vaca-muerta/937624/

Center for Latin American Studies (CLAS). 2018. "Berkeley Review of Latin American Studies - Fall 2018." Accessed July 2019:

https://clas.berkeley.edu/sites/default/files/shared/docs/tertiary/BRLASFall2018-Spreads.pdf

Corporación Andina de Fomento (CAF). 2011. "La Infrastructura en el Desarrollo Integral de America Latina (IDeAL 2011)." Accessed July 2019:

http://scioteca.caf.com/bitstream/handle/123456789/348/infraestructura-desarrollo-americalatina-diagnostico-energia.pdf? sequence $=1 \&$ isAllowed $=y$

Folgar, C. 2016. "The New Argentina: Time to Double Down on the Energy Sector?" Washington, DC: Atlantic Council.

Fundación Ambiente y Recursos Naturales (FARN). 2019. "Fossil Fuel Subsidies in Argentina 2018-2019.” Accessed July 2019: https://farn.org.ar/archives/25350

Fundación de Investigaciones Económicas Latinoamericanas (FIEL). 2017. "Argentina." Accessed June 2019: https:/www.oecd.org/environment/cc/g20-climate/collapsecontents/Fielargentina-growth-and-low-carbon-transition.pdf

Ganem, C. A. 2018. "Taking Stock Of the Macri Energy Reform Agenda: Tariffs and Subsidy Reduction," San Diego, CA: Institute of the Americas, 2018.

Giannetti, A., and Rocca, P. 2018. "Usarán pozos viejos para almacenar el gas de Vaca Muerta." Accessed July 2019: http://www.vacamuerta.com.ar/usaran-pozos-viejos-para-almacenar-el-gasde-vaca-muerta/

Haselip, J.; Dyner, I.; et al. 2005. "Electricity market reform in Argentina: assessing the impact for the poor in Buenos Aires," Utilities Policy, vol. 13, pp. 1-14.

Institute for Energy Economics and Financial Analysis (IEEFA). 2019. "Financial Risk Cloud Development of Argentina's Vaca Muerta Oil and Gas Reserves.” Accessed July 2019: http://ieefa.org/wp-content/uploads/2019/03/Financial-Risks-Cloud-Development-of-VacaMuerta March-2019.pdf 
Instituto Argentino de Petroleo y del Gas (IAPG). 2019. "Estadisticas Interactivas." Accessed April 2019: http://www.iapg.org.ar/estadisticasnew/

Instituto Argentino de la Energía General Mosconi (IAE). 2015. “Consensos Energéticos 2015: la política para salir de la crisis energética.” Accessed July 2019: http://web.iae.org.ar/wpcontent/uploads/2015/09/Ex-Secretarios-Consensos-energ--ticos-2015.pdf

International Business Publications. 2015. “Argentina Energy Policy, Laws and Regulations Handbook, Vol. 1: Electricity Generation, Development and Regulations." Washington, DC, 2015.

International Group of Liquefied Natural Gas Importers (GIIGNL). 2019. "The LNG Industry GIIGNL Annual Report 2019.” Accessed May 2019: https://giignl.org/sites/default/files/ PUBLIC AREA/Publications/giignl annual report 2019-compressed.pdf

Jorgelina do Rosario and David Biller. 2019. "Argentina's Economists Warn of Deeper Slump as Crisis Escalates," Bloomberg, September 4, 2019. https://finance.yahoo.com/news/argentinaeconomists-warn-deeper-slump-135801010.html

LaMarca, K., 2011. "Renewable Energy Initiatives: A Look At Argentina and Law 26,190," Law and Business Review of the Americas, vol. 17, no. 3, pp. 583-592.

Mastropietro, P.; Batlle, C.; et al. 2016. "The Evolution Of Electricity Auctions in South America," Energy Sources, Part B: Economics, Planning, and Policy, vol. 11, no. 12, pp. 11031110 .

MercoPress. 2016. "Argentina Ends Power Subsidies; Some Bills Could Increase by as Much as 500\%." Accessed July 2019: https://en.mercopress.com/2016/01/30/argentina-ends-powersubsidies-some-bills-could-increase-by-as-much-as-500

Nordrum, A. 2019. "Transmission Failure Causes Nationwide Blackout in Argentina." Accessed July 2019: https://spectrum.ieee.org/energywise/energy/the-smarter-grid/transmission-failurecauses-nationwide-blackout-in-argentina

Olave, X.; Garcia-Uriburu, P.; et al. 2015. “Argentine Electricity Sector: Awaiting Structural Reform.” New York, NY: Fitch Ratings.

Oxford Institute for Energy Studies. 2016. "South American Gas Markets and the Role of LNG." Accessed December 2018: https://www.oxfordenergy.org/wpcms/wpcontent/uploads/2016/10/South-American-Gas-Markets-and-the-Role-of-LNG-NG-114.pdf

Pampa Energia. 2019. “The Argentine Electricity Sector.” Accessed July 2019: https://ri.pampaenergia.com/en/our-assets/electricity-power/the-argentine-electricity-sector/

PWC. 2017. "Renewables in Argentina: Opportunities in a New Business Environment." Accessed March 2019: https://www.pwc.com.ar/es/publicaciones/assets/renewables-inArgentina.pdf 
Renewables Now. 2019. "Argentina Awards 259 MW in RenovAr 3". Accessed November 2019: https://renewablesnow.com/news/argentina-awards-259-mw-in-renovar-3-664495/

Reuters. 2019. “Argentina Authorizes New Gas Exports to Chile.” Accessed May 2019: https://www.reuters.com/article/us-argentina-chile-gas/argentina-authorizes-new-gas-exports-tochile-idUSKCN1R12ZY

Secretaría de Energía. 2018 . “Argentina Energy Plan - Guidelines.” Accessed March 2019: http://www.energia.gob.ar/contenidos/archivos/Reorganizacion/planeamiento/argentina-energyplan.pdf

Secretaría de Energía. 2018b. "Energy Scenarios 2030.” Accessed July 2019:

http://datos.minem.gob.ar/dataset/9e2a8087-1b49-446a-8e86-712b476122fb/resource/a43a7a0d36e0-4c4c-81c4-ea6387c923f4/download/minem-energy-scenarios-2030puben.pdf

Secretaría de Energía. 2019a. "Acerca del Evento Eléctrico del 16 de Junio.” Accessed August 2019: http://www.energia.gob.ar/contenidos/archivos/Reorganizacion/planeamiento/ publicaciones/presentacion-03-07-2019.pdf

Secretaría de Energía. 2019b. "Producción de Petróleo y Gas.” Accessed July 2019: https://www.argentina.gob.ar/energia/hidrocarburos/produccion-de-petroleo-y-gas

U.S. EIA. 2019. “Today in Energy: Growth in Argentina's Vaca Muerta Shale and Tight Gas Production Leads to LNG Exports." Accessed July 2019:

https://www.eia.gov/todayinenergy/detail.php?id=40093

U.S. EIA. 2017. "Today in Energy: Argentina Seeking Increased Natural Gas Production from Shale Resources to Reduce Imports." Accessed May 2019: https://www.eia.gov/todayinenergy/detail.php?id=29912

Yaneva, M., Tisheva, P.; et al. 2018. “2018 Argentina Renewable Energy Report,” Accessed March 2019: http://minaaysp.cba.gov.ar/wp-content/uploads/2018/06/AIRECweek-2018-TheArgentina-Report.pdf 


\section{Brazil}

\subsection{Electricity Sector Overview}

The Brazilian electricity sector is the largest in South America and the third largest in the Americas. In this section, a brief overview of the history, organization, as well as the evolution of the electricity generation and consumption in the Brazilian electricity sector is presented.

\subsubsection{Brief History and Sector Organization}

The Brazilian electricity sector has undergone profound changes. Until the 1940s, it was characterized by private ownership with poor regulation for electricity generation, transmission, and distribution. Then, state ownership with centralized control was predominant from the 1950s to the early-1990s. Since the mid-1990s, the sector has been characterized by mixed ownership, increased privatization, and sophisticated regulation (Da Silva 2007). In 1997, the Brazilian Electricity Regulatory Agency (ANEEL) was created to regulate and monitor the generation, transmission, distribution, and commercialization of energy. In 1998, the National System Operator (ONS) was created to monitor and coordinate the National Interconnected System (SIN). In 2004, a new regulatory framework based on long-term electricity auctions was introduced. In the same year, the Energy Research Office (EPE) was created to support the policy decisions of the Ministry of Mines and Energy (MME) with planning studies for the energy sector.

The Brazilian electricity market is coordinated by the Chamber of Energy Commercialization (CCEE) and is comprised of two contracting environments as described in Table 6.

Table 6. Contracting Environments in the Brazilian Electricity Market

\begin{tabular}{|l|l|l|}
\hline \multicolumn{1}{|c|}{ Characteristics } & Free Contracting Environment & \multicolumn{1}{|c|}{$\begin{array}{c}\text { Regulated Contracting } \\
\text { Environment }\end{array}$} \\
\hline Participants & $\begin{array}{l}\text { Generators, traders, and large } \\
\text { consumers }\end{array}$ & $\begin{array}{l}\text { Generators, utilities, and } \\
\text { traders }\end{array}$ \\
\hline Trading & $\begin{array}{l}\text { Free trading between buyers } \\
\text { and sellers }\end{array}$ & $\begin{array}{l}\text { Through auctions coordinated } \\
\text { by CCEE }\end{array}$ \\
\hline Contracting & Free agreements & Regulated by ANEEL \\
\hline Price & $\begin{array}{l}\text { Mutually agreed between } \\
\text { buyers and sellers }\end{array}$ & Defined through auctions \\
\hline
\end{tabular}

Source: Adapted from CCEE (2019a)

There are two types of long-term electricity auctions currently adopted in Brazil in the regulated contracting environment:

- Regulated Auctions are designed to fulfill the electricity demand of utility companies. Through regulated auctions, long-term contracts (spanning from 20 to 30 years depending on the generation source) are established between utilities and independent producers 
(existing and/or new power plants). In particular, the auctions for alternative sources are designed to promote renewable energy sources such as wind, solar, biomass, and small hydropower in the Brazilian electricity sector.

- Reserve Auctions are designed to improve the supply adequacy of the National Interconnected System by increasing the reserve margin of the entire system. Through reserve auctions, reserve energy contracts are established between independent producers (existing and/or new power plants) and CCEE, which divides the reserve energy costs among all consumers.

In both auction types, the tenders are centralized (i.e., ANEEL and MME define the amount of energy to be procured, contract provisions, and type of energy source) (Mastropietro et al 2016).

\subsubsection{Consumption}

From 2000 to 2015 , electricity consumption increased nearly $60 \%$, due to the industrial development and economic growth. However, since 2015 Brazil has suffered from economic instabilities, which have significantly impacted the electricity consumption, especially in the industrial sector. Figure 30 shows the evolution of the electricity consumption by sector in Brazil from 2000 to 2018 .

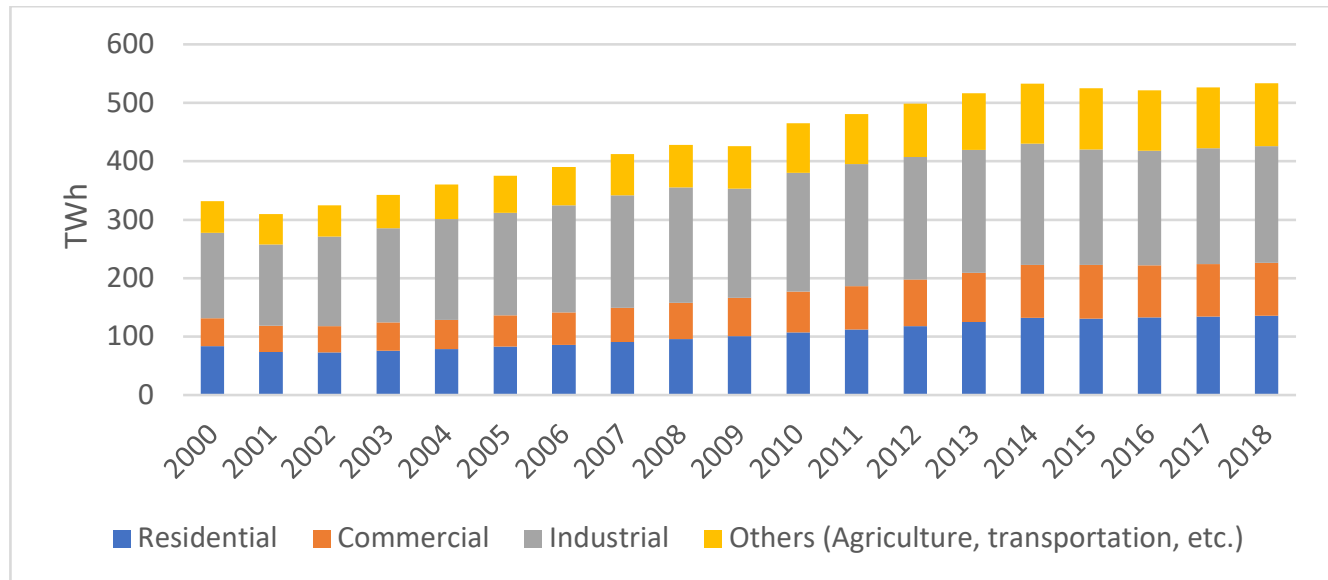

Source: Data from EPE (2019a)

Figure 30. Electricity consumption by sector in Brazil

\subsubsection{Generation}

\subsubsection{Hydropower}

Brazil has been historically characterized by a hydro-dominated generation mix due to its enormous hydroelectric potential and the many advantages of this generation source (low operation cost, storage capacity, clean, renewable, etc.). However, the share of hydropower in the country's installed capacity has decreased significantly in recent years mainly due to socioenvironmental issues, the high initial investment costs, and the additional investments in transmission lines, especially for projects located in remote areas distant from consumption centers (EPE 2018b). 
Figure 31 shows the total and regional installed capacity, respectively, in Brazil in the years of 2008 and 2018. Nearly $80 \%$ of the new hydroelectric installed capacity in the last ten years is in the North and Central-West regions, which together account for more than $65 \%$ of the $135 \mathrm{GW}$ untapped hydroelectric power capacity in Brazil (EPE 2018b). Both regions, however, are facing challenges to expand their hydroelectric capacity since they contain environmentally sensitive areas, such as the Brazilian Amazon rainforest and the Pantanal, which have strict environmental laws and face strong public opposition to new hydroelectric projects. Figure 32 illustrates changes in the generation mix in Brazil since 2001 and highlights the fall-off in hydropower output during the drought years of 2011 to 2015.

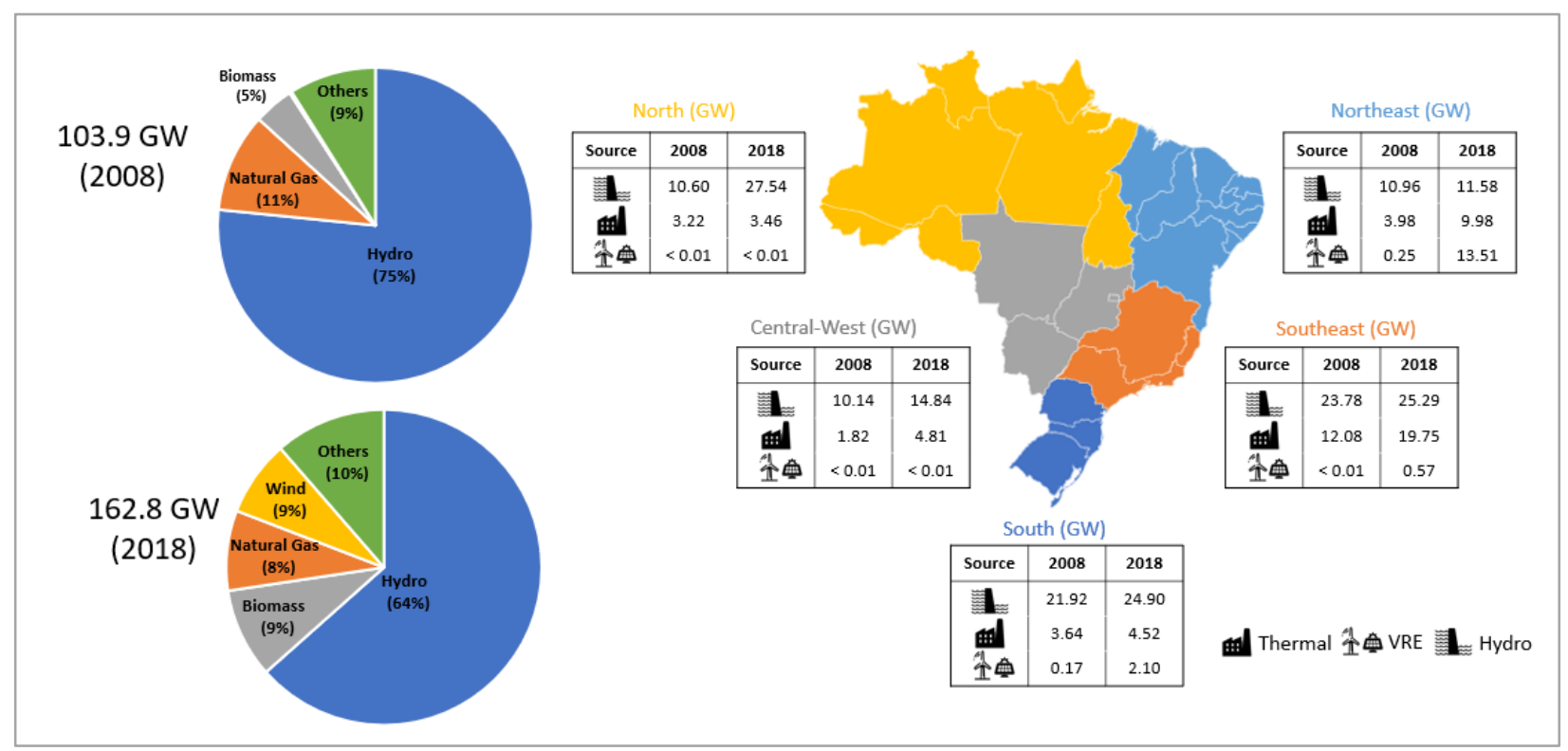

Source: Data from EPE (2019a)

Figure 31. Total and regional installed capacity in Brazil in 2008 and 2018 


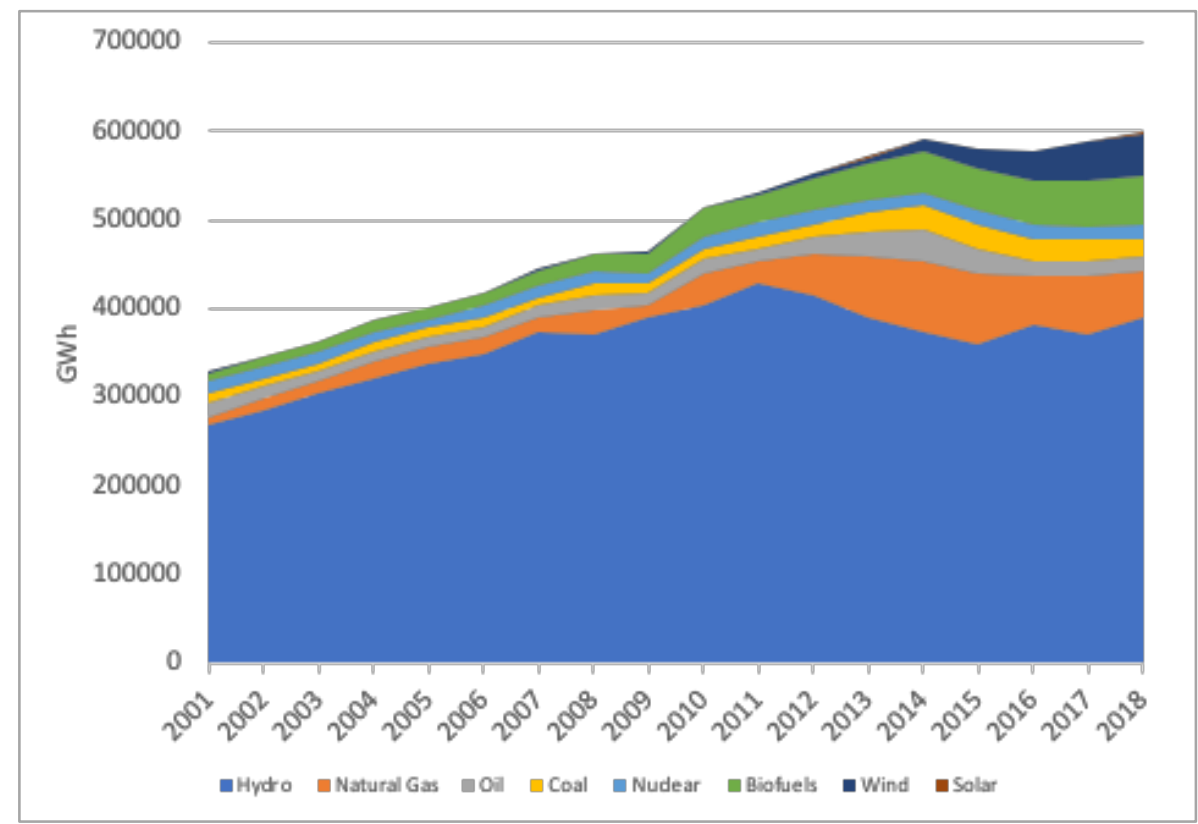

Source: EPE (2019a) and IEA (2019)

Figure 32. Evolution of electricity generation mix in Brazil, 2001-2018

\subsubsection{Other Renewable Energy Sources}

In contrast to hydropower, the share of wind power and biopower in the installed capacity increased significantly in the same period due to the increasing availability of biomass, the cost reduction of wind power systems, and the incentives for renewable energy production.

Since 2009, several renewable energy auctions have been successfully implemented, thus contributing to an exponential growth of the variable renewable energy (VRE) installed capacity, which increased from less than $1 \mathrm{GW}$ in 2009 to $18 \mathrm{GW}$ in 2019 , accounting for more than $10 \%$ of the total installed capacity in the country (Figure 33). 


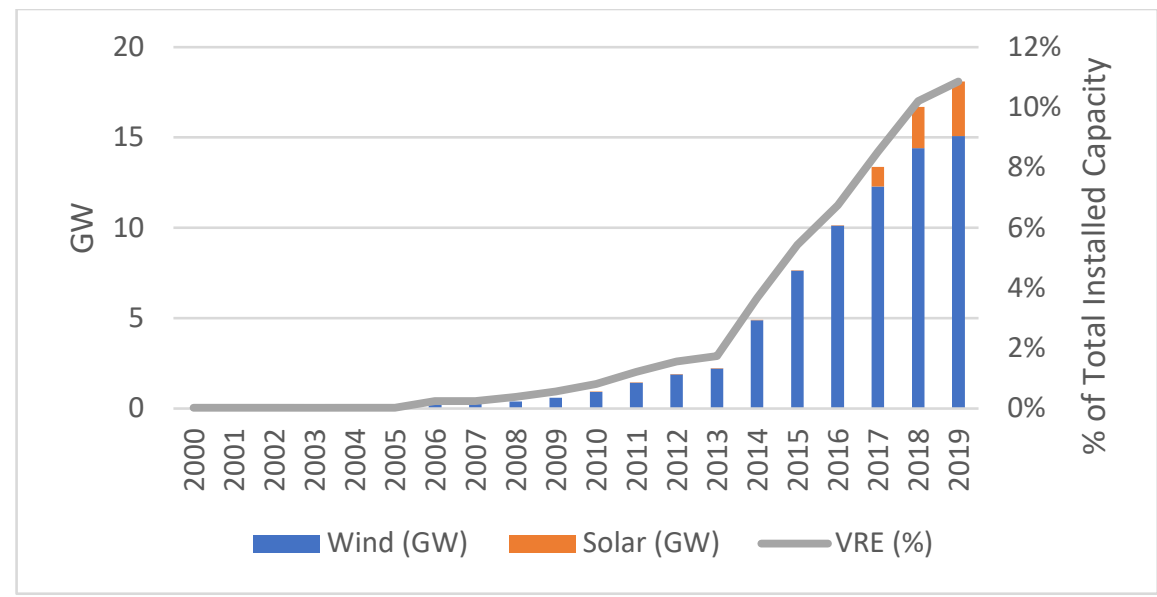

Source: Data from EPE (2019a)

Figure 33. VRE installed capacity evolution in Brazil ${ }^{8}$

As shown in Figure 34, the move toward increasing VRE integration in Brazil started in 2004 with the first feed in tariff program for wind power (PROINFA). The first regulatory framework for distributed generation (DG) in Brazil was officially issued in 2012 where ANEEL established net metering rules in Brazil, thus allowing small-scale customers to produce their own generation and receive credits in $\mathrm{kWh}$ for the surplus exported to the grid. Since then, the number of DG units has increased significantly. In 2019, Brazil reached more than 82,000 DG units totaling 1 GW of installed capacity, with approximately 870 MW from solar PV units (ANEEL 2019).

${ }^{8} 2019$ data thru July. 


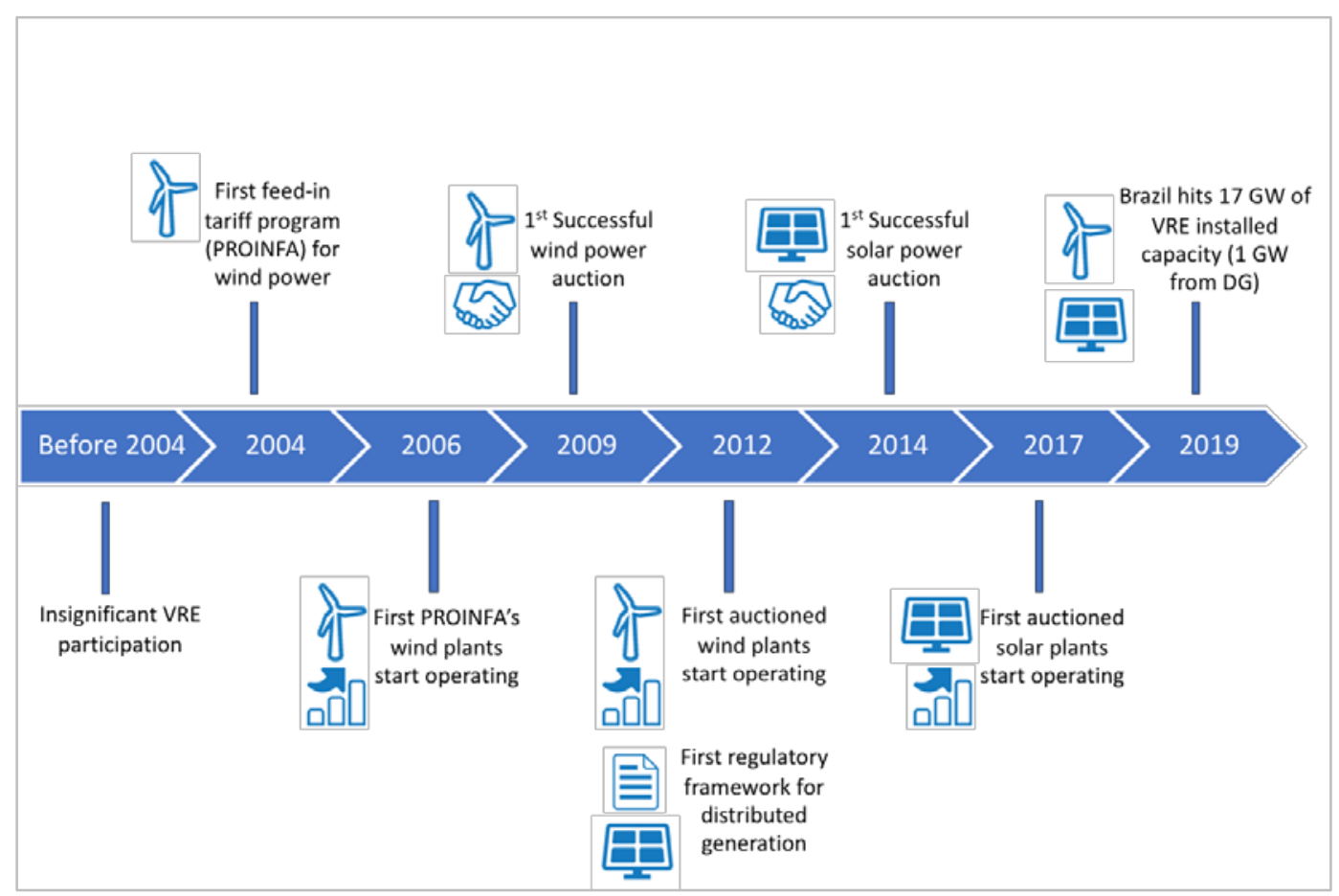

Source: Adapted from EPE (2018c)

Figure 34. VRE evolution in Brazil

Biomass power plants have increased their participation in the Brazilian generation mix in the last decade as well. They are considered non-dispatchable power plants in long-term energy planning since electricity generation is generally not their main process (i.e., the energy they export to the grid is derived from the by-products of other industrial processes) and also because of the seasonal and variable production of biomass.

\subsubsection{Transmission Infrastructure}

The Brazilian transmission system is comprised of more than 85,000 miles of transmission lines, and more than $98 \%$ of the electricity demand is connected to SIN. Figure 35 shows the existing Brazilian transmission system with the planned expansion until 2027. One of the main advantages of an interconnected transmission system like SIN is the possibility to exchange energy between regions and explore the complementarity of different sources of generation. Brazil's transmission system is relatively well connected with its neighboring countries. The country has interconnections with Argentina, Paraguay, Uruguay, and Venezuela. 


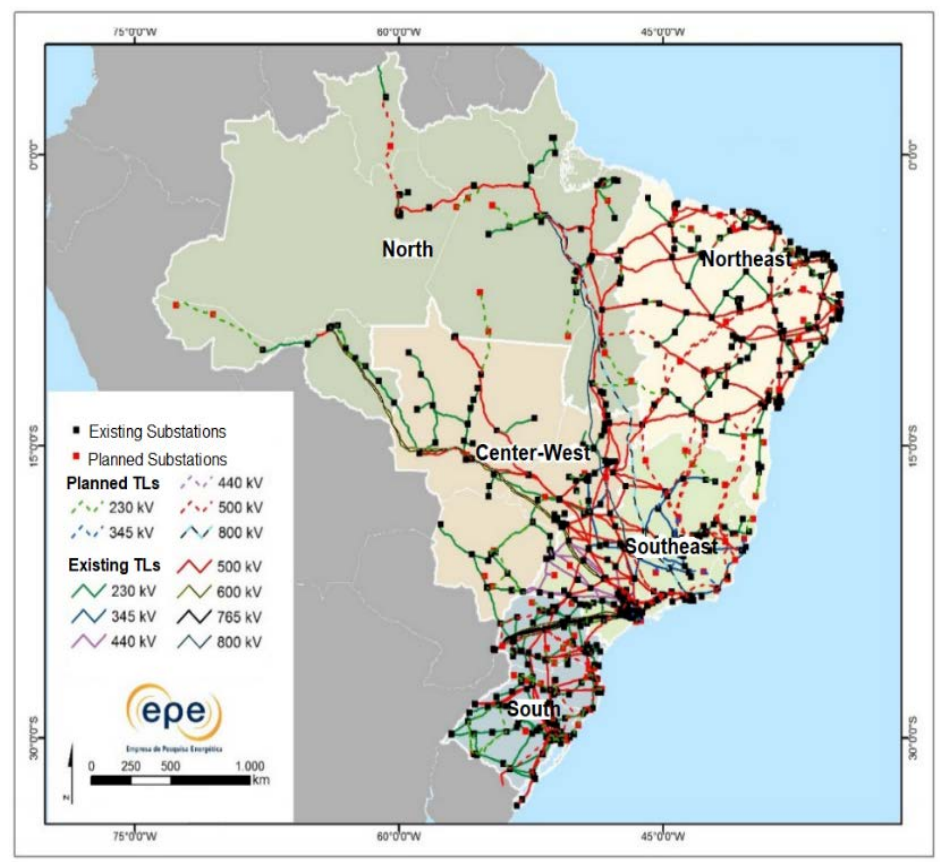

Source: Adapted from EPE (2018a)

Figure 35. Existing and planned (until 2027) Brazilian transmission system

\subsection{Natural Gas Overview}

Brazil is a significant natural gas market. The country is currently the third-largest producer and the second-largest consumer of natural gas in South America, only surpassed by Argentina and Venezuela on the production side, and by Argentina on the consumption side.

\subsubsection{Sector Organization}

The Brazilian natural gas sector is regulated by the National Agency of Petroleum, Natural Gas, and Biofuels, which is linked to the Ministry of Mining and Energy (MME). Petrobras, which is a majority state-owned oil and gas company, produces approximately $80 \%$ of the total natural gas produced in Brazil and has substantial control over natural gas transmission and distribution. Most of the natural gas volumes traded in the wholesale market are based on long-term contracts with Petrobras (IEA 2018b).

\subsubsection{Consumption}

Before the completion of the Bolivia-Brazil (GASBOL) pipeline in 1999, the share of natural gas in Brazil's total primary energy supply (TPES) never surpassed 4\% (Oxford Institute for Energy Studies 2016). With increasing investments in domestic natural gas production and the development of LNG markets, the share of natural gas in the TPES increased to $13 \%$ in 2018 . As shown in Figure 36, the natural gas consumption in Brazil has displayed a significant growth in different sectors, but the most rapid growth has been in the electricity sector. The natural gas demand in the residential and commercial sectors accounted for less than $2 \%$ of the total demand in 2018. This can be explained by the limited need for heating due to the predominant tropical climate in Brazil, the limited natural gas urban infrastructure, and the government subsidies for liquefied petroleum gas (LPG), or propane, used for cooking (Oxford Institute for Energy Studies 2016). 


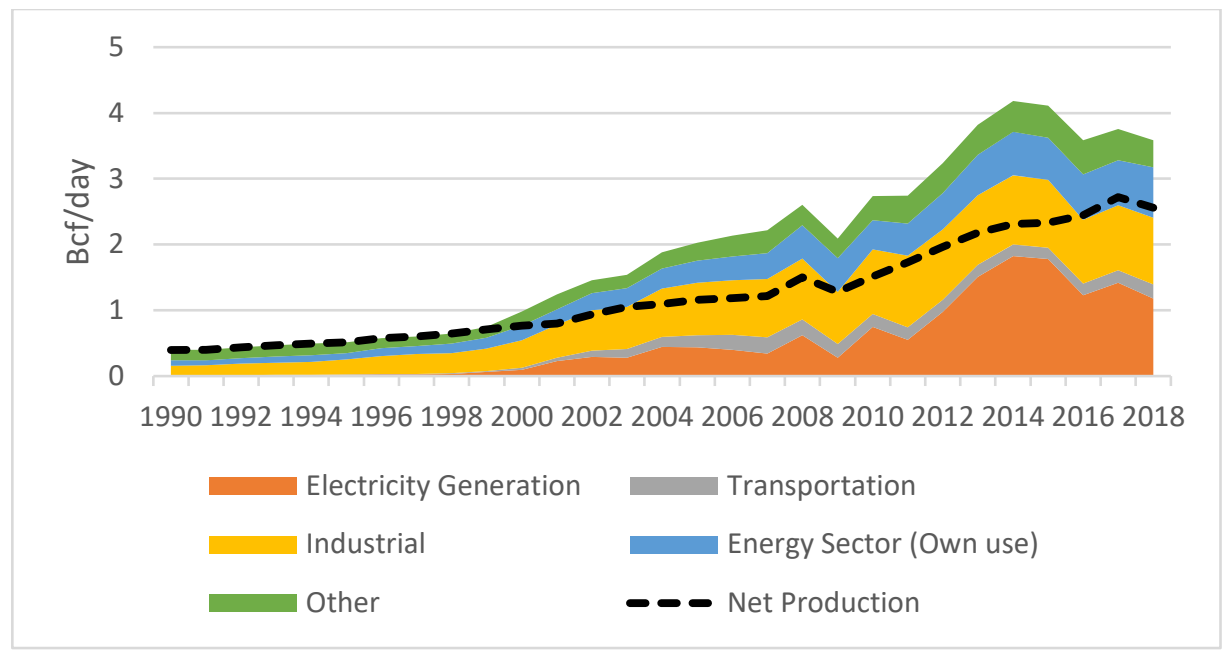

Source: Data from EPE (2019a)

Figure 36. Natural gas consumption in Brazil by sector versus net production

In 2000, the country announced an emergency program (Thermopower Priority Program - PPT, in Portuguese) that offered lower natural gas prices for 20 years to natural gas-fired power plants commissioned by December 2004 (Oxford Institute for Energy Studies 2016). With the PPT program, the thermal power installed capacity in the country increased from $10 \mathrm{GW}$ in 2000 to nearly $20 \mathrm{GW}$ in 2004, thus pushing the natural gas demand beyond Brazil's traditional supply.

\subsubsection{Domestic Production}

Domestic natural gas production in Brazil has increased significantly in the last 15 years but has not followed demand growth. In 2007, the country announced a major deep-water hydrocarbon deposit discovery in the Pre-salt areas of the Campos, Santos, and Espírito Santo basins with potential to boost the oil and gas industry and position the country among the top ten oil producers.

As of 2018, Brazil held approximately 13 trillion cubic feet (Tcf) of natural gas proved reserves where more than 80\% are located offshore (ANP 2019a). Most of the domestic natural gas in Brazil is associated with oil production and a substantial percentage of the produced gas is reinjected to maintain reservoir pressure. In 2018, more than $30 \%$ of the produced gas was reinjected (ANP 2019b). Brazil also has unconventional gas reserves, but a great part of them are located in environmentally sensitive areas distant from demand and transportation infrastructure, thus challenging further exploration and development.

Exploration and development of oil and gas from the Pre-salt fields are not fully mature and face several techno-economic challenges, mainly due to the high costs to remove significant concentrations of carbon dioxide $\left(\mathrm{CO}_{2}\right)$ from natural gas in some regions and the large distances between the exploration fields and the shore (Coelho 2019). Despite the challenges, the production of natural gas from Pre-salt fields increased from 2 million $\mathrm{m}^{3} /$ day in 2010 to more than 61 million $\mathrm{m}^{3} /$ day in 2018 (ANP 2019b). 


\subsubsection{Imports}

With the government incentives for thermal power generation in the early 2000s, the natural gas demand was pushed beyond Brazil's traditional supply sources and the country started to import significant amounts of natural gas via pipeline (especially from Bolivia) and LNG transactions as shown in Figure 37.

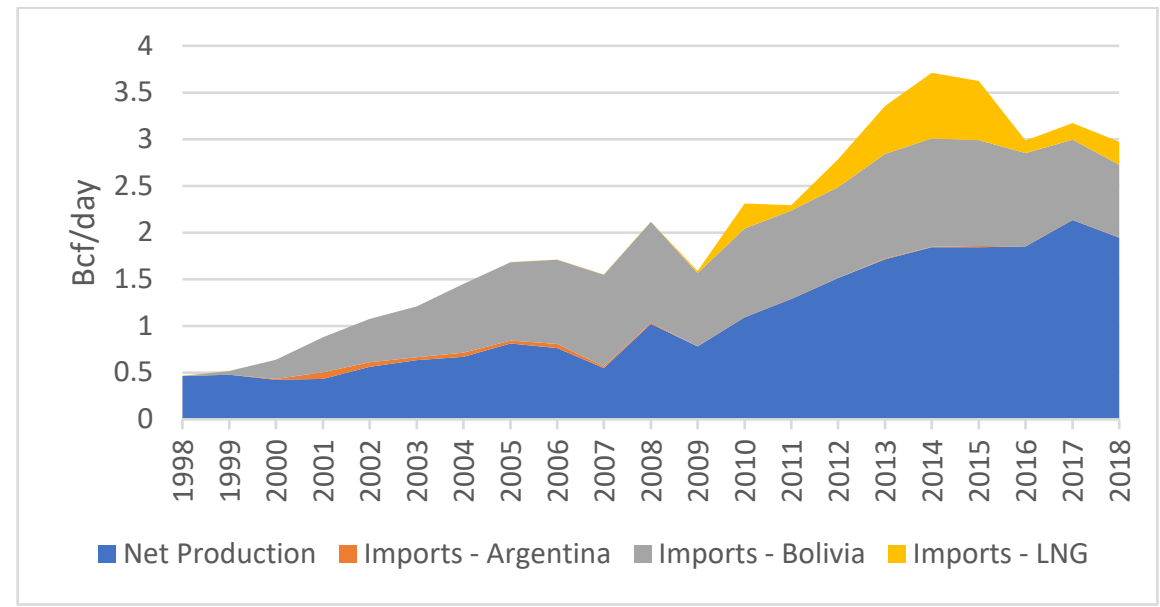

Source: Data from ANP (2019b)

Figure 37. Natural gas net production and imports in Brazil

\subsubsection{Pipeline Imports}

The construction of GASBOL was an important step towards greater use of natural gas in many sectors. However, the nationalization of Bolivia's hydrocarbons in 2006 led to the decline of many gas fields and the reduction in the levels of proven reserves of natural gas due to the lack of investments in the sector, especially in exploration. As a consequence, the country has been failing to deliver the minimum gas volumes required in its long-term contract with Petrobras, which is planning to gradually reduce the volumes of natural gas imported from Bolivia (ARGUS 2019).

\subsubsection{LNG Imports}

LNG has become an important source of flexible supply to meet peak demand. In 2008, Brazil inaugurated its first LNG regasification terminal (Port of Pecem) in the state of Ceará. Today, the country has two FSRUs operating in three terminals (Pecem, Baía de Todos os Santos, and Baía de Guanabara). Brazil imports most of its LNG in the spot market from countries in the Atlantic basin, such as Trinidad and Tobago, Nigeria, and the United States, due to better logistics and lower transportation costs.

Although LNG has become an important flexible option for power generation in Brazil, the imported LNG volumes have remained significantly below the country's maximum regasification capacity (EPE 2018d). Due to the low demand and the high operational costs, Petrobras terminated the contract of the Golar Spirit FSRU, which left Baía de Guanabara Port in 2017. Figure 38 shows Brazil's LNG imports by country of origin. LNG imports from the U.S. have increased in the last three years, reaching $36 \%$ of the total imports in 2018. 


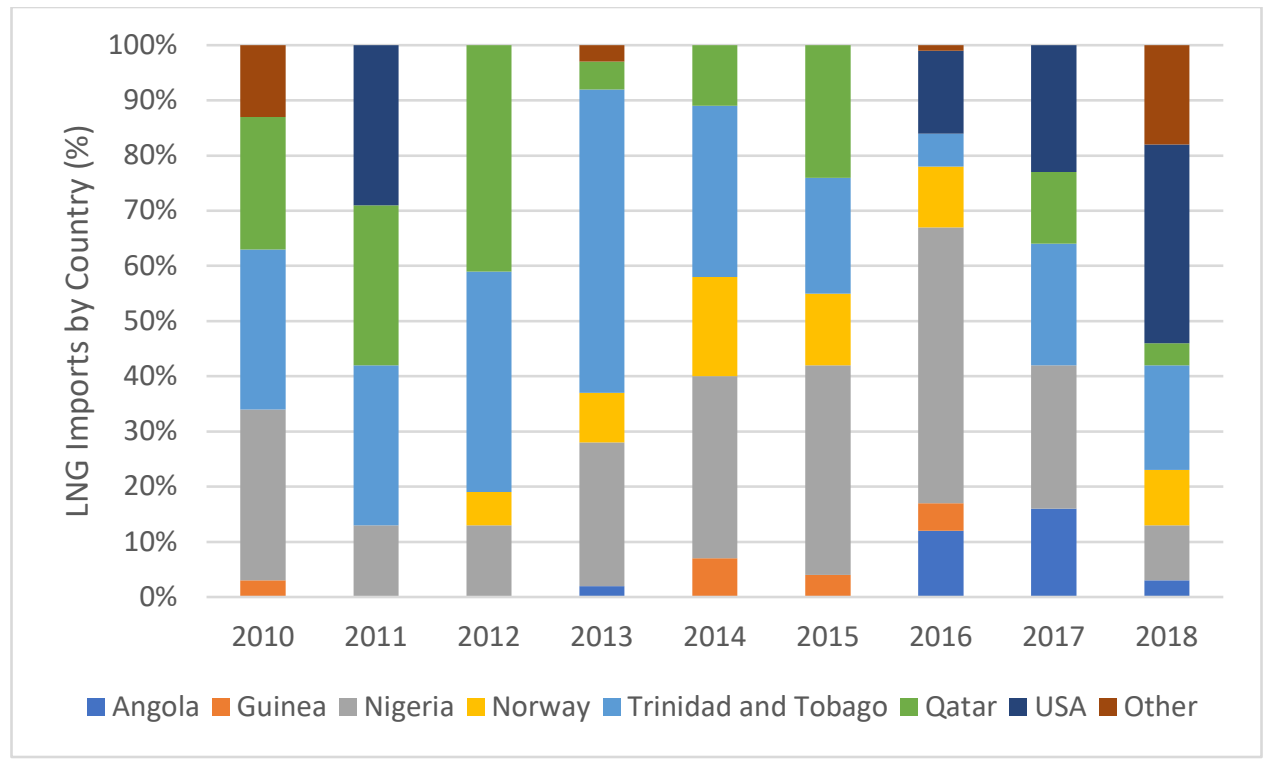

Source: Data from GIIGNL (2019)

Figure 38. Brazil's LNG imports by country of origin

\subsubsection{Natural Gas Transportation Infrastructure}

The limited natural gas transportation infrastructure has prevented greater use of natural gas in the electricity and industrial sector. Figure 39 shows how the existing natural gas transportation network, with approximately 5,900 miles of gas pipelines, is underdeveloped in comparison to the electricity network, which encompasses more than 85,000 miles of transmission lines.
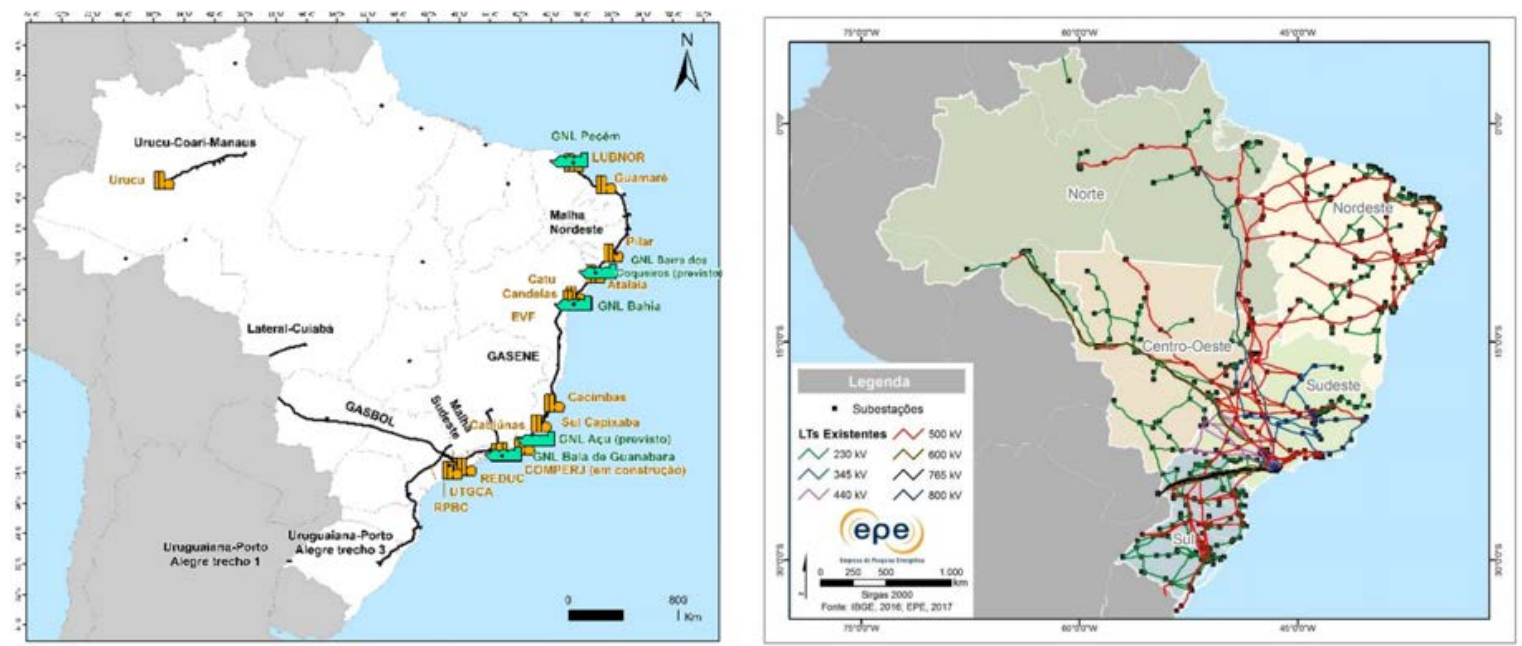

Source: EPE (2018a)

Figure 39. Brazil's natural gas (left) and electricity networks (right) 


\subsection{Power System Flexibility}

\subsubsection{Sources of Flexibility}

\subsubsection{Impoundment Hydropower Plants}

Historically, large impoundment hydropower plants have been the main source of short-, medium-, and long-term power system flexibility in Brazil. Most hydropower plants are centrally dispatched by ONS, which performs the economic dispatch, minimizing the system operation cost and optimizing the water storage considering different future water inflow scenarios.

\subsubsection{Thermal Power Plants}

In recent years, however, dispatchable thermal power plants (natural gas, coal, oil, etc.) have become important flexibility providers, complementing hydropower in periods of unfavorable hydrological conditions. Thermal power plants in Brazil are primarily comprised of flexible generating units that have low fixed costs and high variable costs, operating with low capacity factors. However, several high-efficiency combined-cycle power plants contracted in recent auctions operate with relatively higher capacity factors. In the Regulated Contracting Environment, thermal power plants are contracted in auctions through availability contracts with prespecified fixed payments associated with their availability to be dispatched at any time and variable costs associated with fuel costs.

As previously mentioned, LNG has become an important fuel to address hydropower variation and seasonality and enhance the flexibility needs of the country. Imported LNG is almost exclusively used for electricity generation in dry seasons (EPE 2018d). Figure 40 shows how LNG imports increased during the periods of reduced hydropower production in 2012-2015. LNG prices in such periods are usually lower since the periods of lower rainfall in Brazil (MaySeptember) correspond to the periods of lower natural gas demand for heating in the Northern Hemisphere. However, due to costs associated with transportation and regasification, imported LNG prices (from the spot market) are about 30\% higher than domestic natural gas prices (EPE 2019b).

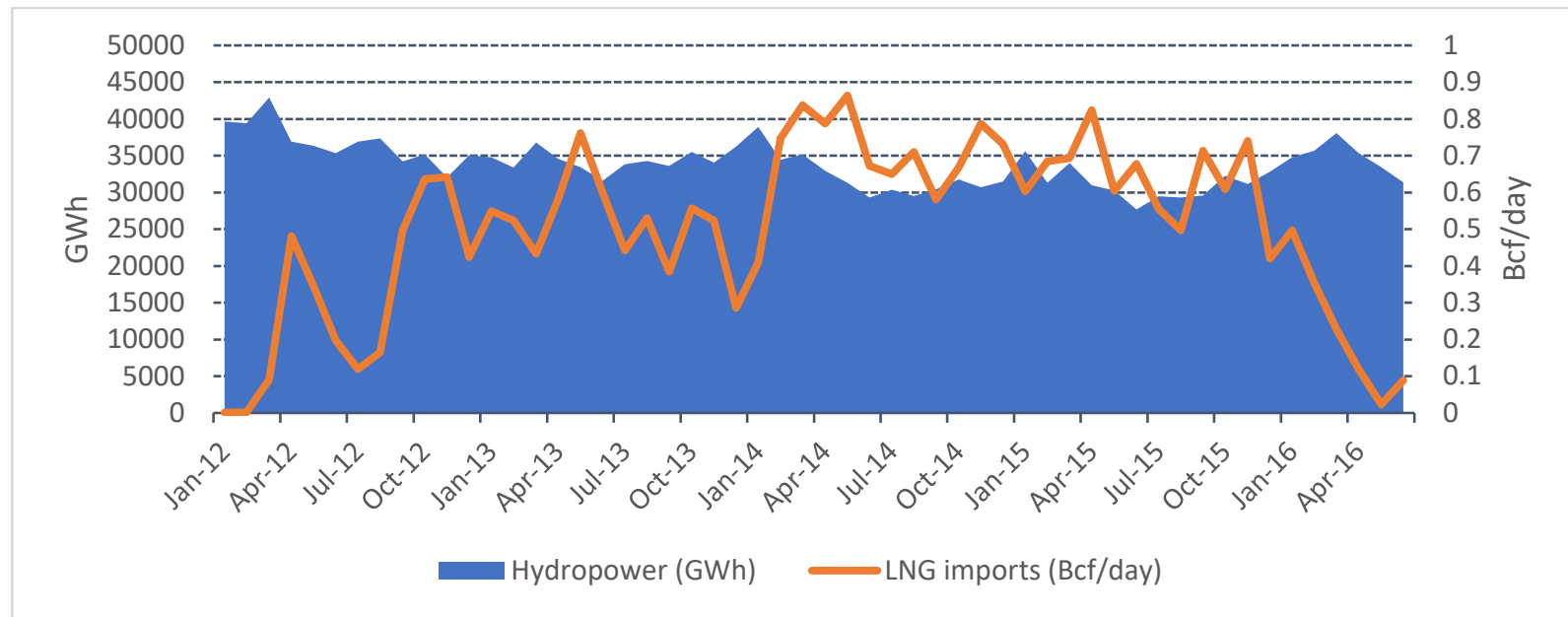

Source: Data from EPE (2018a) and ANP (2019a)

Figure 40. Hydropower production and LNG imports in Brazil 
Over the past few years there has been increasing discussion among several stakeholders on the future flexibility provision from natural gas and hydropower plants in Brazil. In particular, generation from natural gas power plants has received increasing attention, as described in Text Box 7.

Text Box 7. Base-Load Generation from Natural Gas Power Plants in Brazil

The use of efficient thermal power plants - primarily natural gas power plants - has received increasing attention in recent years. This option is justified by the potential of greater natural gas production from the Pre-Salt fields and the possibility to better explore the flexibility capabilities of hydropower plants, which could store more water to be used in dry seasons. This option, however, would rely on effective market mechanisms to monetize the natural gas from the Pre-Salt fields in order to ensure competitive and stable natural gas prices and to reduce uncertainties and risk exposures of producers and consumers. Currently, natural gas power plants with high variable costs (i.e., under inflexible take-or-pay natural gas arrangements or heavily dependent on LNG from the spot market) have been dispatched for long periods of low hydropower production (due to prolonged adverse weather events), thus resulting in higher electricity prices, which are passed on by utilities to their customers, and increasing price volatility. Figure 41 shows how the electricity spot prices increased in the Northeast region of Brazil as more thermal power plants were dispatched during the El Nino of 2014-2016. EPE acknowledges the increasing importance of natural gas power plants in Brazil (EPE, 2018e) and is working with other stakeholders on strategies to ensure lower operational costs and better integrate them in the Brazilian electricity market.

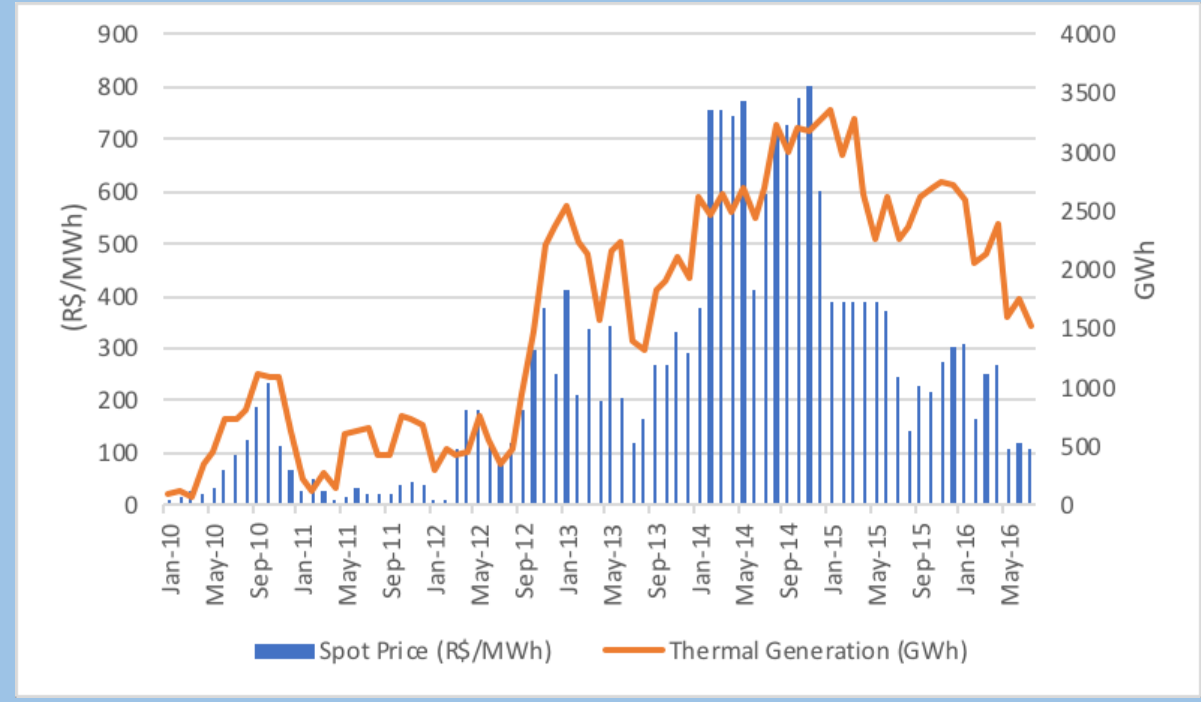

Source: Data from CCEE (2019a) and ONS (2019b)

Figure 41. Spot electricity price and thermal generation in the Northeast region of Brazil 


\subsubsection{Other renewables}

The increasing integration of non-dispatchable renewable energy sources such as wind, solar, and biomass have contributed to the diversification of the Brazilian generation mix and the provision of flexibility at higher time scales.

\subsubsection{Drivers of the Need for Flexibility}

\subsubsection{Rainfall Variability}

One of the main drivers of long-term flexibility (in a monthly basis or more) in Brazil's electricity sector is the seasonal rainfall variability. In addition, occasional weather phenomena, such as the El Niño Southern Oscillation (ENSO) can intensify the effects of wet and dry periods in unpredictable ways. Due to its large latitudinal extension, Brazil has experienced different regional effects in the same ENSO phase. During periods of El Niño, the North and Northeast regions have rainfall below normal whereas the Central-West and South regions have rainfall above normal. During periods of La Niña, the effects on rainfall are typically the opposite. This behavior is illustrated in Figure 42 for the South region and Figure 43 for the Northeast region, which are significantly affected by ENSO events. The figures show a comparison between average water storage capacity (in GW) and two periods with significantly different levels of precipitation (i.e., December-April as defined by ANEEL). The wet period of 2008-2009 was characterized by significant La Niña occurrences $(\mathrm{ONI} \leq-0.5)$ whereas the wet period of 20092010 was characterized by significant El Niño occurrences (ONI $\geq 0.5)$. The Southeast region, with the highest hydropower installed capacity in Brazil, does not present characteristic changes in precipitation during ENSO events. However, other weather phenomena such as atmospheric blocks over the South Atlantic convergence zone can lead to significant reductions in rainfall, and consequently lower hydropower production in that region.

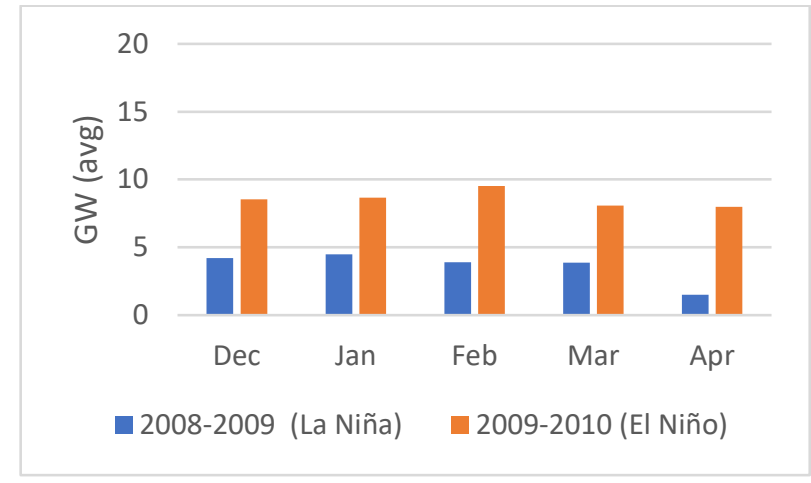

Source: Data from EPE (2018a)

Figure 42. Water storage capacity in two distinct wet periods in Brazil's South region 


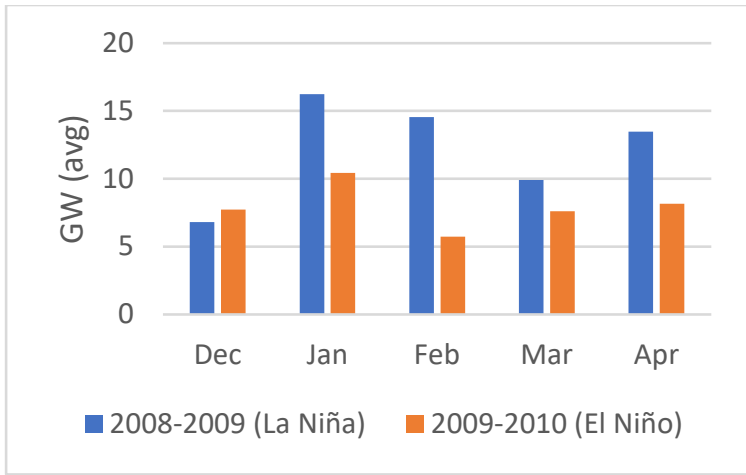

Source: Data from EPE (2018a)

Figure 43. Water storage capacity in two distinct wet periods in Brazil's Northeast region

\subsubsection{Public Opposition to Hydropower Plants}

Increasing social opposition and stricter environmental laws for projects that require flooding of large environmentally sensitive areas have contributed to the reduction of new impoundment power plants and the increasing adoption of run-of-the-river power plants, which generally cannot provide long-term flexibility (in a monthly basis or more) due to the lack of large reservoirs (EPE, 2018e). In addition, the North region, with approximately $50 \%$ of the Brazilian untapped hydroelectric power capacity, is mainly comprised of rivers with low falls and high flows, which makes it difficult to build large reservoirs (CNI 2018). In general, the available reservoirs can store enough water in wet periods to be released to generate power in dry periods, maintaining low electricity prices throughout the year. Prolonged weather phenomena that reduce rainfall for long periods can lower water in reservoirs to critical level. In such a case, thermal power plants (mostly natural gas) with high variable costs are dispatched to complement hydropower generation. Run-of-the-river power plants, which can provide short-term flexibility services are also facing increasing public opposition. The Belo Monte power plant, which started operating in 2016, is an example of a diversion power plant that suffered from huge public oppositions during its construction due to the displacement of several indigenous communities native from the Brazilian Amazon (Fearnside 2017).

\subsubsection{Growing VRE Integration}

The growing penetration of VRE sources, such as wind and solar, has increased the need of short-term flexibility at lower timescales. Most of the VRE installed capacity is located in the Northeast region, which calls for additional short-term flexibility provision in that region.

\subsection{Key Policy Options to Enhance Flexibility in Brazil}

As Brazil looks to define planning strategies to ensure power system flexibility and an effective integration of the electricity and natural gas sectors, a variety of policy options are available for policy makers to implement. This section presents some key policy options to enhance flexibility in Brazil and recent efforts to implement some of these options.

\subsubsection{Electricity Sector Policy Options}

Generation Mix Diversification: VRE sources are expected to continue increasing their participation in the Brazilian generation mix as the costs of wind and solar systems continue to 
decrease (EPE 2018e). They may provide long-term flexibility, especially in the Northeast region which has been suffering from prolonged droughts. Other alternative generation options that could contribute for greater future flexibility but need further development in Brazil include tidal power and waste-to-energy.

Demand Side Management: There is also a great potential for flexibility provision through demand side management in Brazil, and the country has started to leverage this potential. In November of 2017, ANEEL approved the first demand-response pilot program for large consumers in Brazil. This program, which started in 2018, was designed to be an alternative to the out-of-merit dispatch of thermal power plants used to compensate the lower hydropower generation and the wind power variability in the Northeast region. It allows large industrial customers located in the North and Northeast regions to reduce their electricity consumption in exchange for financial incentives. However, only two industrial customers are currently participating in this program due to existing participation restrictions. CCEE and ONS are working to identify opportunities to increase customer participation and implement future demand-response programs in the whole country (ONS and CCEE 2018). In July of 2019, EPE published a report on the potential of demand response in Brazil and its implications on the Brazilian long-term energy planning (EPE 2019c).

Storage Systems: With the reduced participation of hydropower plants with large reservoirs in the Brazilian generation mix, there is a significant opportunity for the development of pumpedstorage hydroelectricity for flexibility provision in the country. EPE is currently working on technical studies aimed to identify the pumped-storage capacity in Brazil and define key regulatory aspects for integrating pumped-storage hydropower plants in the Brazilian power system (EPE 2019d).

Regional Interconnections: The expansion of the existing transmission capacity could allow the country to foster greater flexibility and energy exchange between regions in order to better explore the existing regional complementarities (and even the opposite effects of weather events in different regions) and maximize the use of VRE (which could be transmitted from remote areas to the main consumption centers).

Distributed Energy Resources (DERs): Brazil has over $1 \mathrm{GW}$ of DG installed capacity-which is mostly compensated through net metering - and this number is expected to grow quickly in the coming years. However, one option to better take advantage of the benefits provided by DERs is to develop a compensation mechanism able to precisely monetize their value (not only in terms of flexibility, but also reliability, resilience, etc.) to the system taking into account different time scales and flexibility requirements.

Effective Pricing Mechanisms: Brazil is already working to reformulate its electricity pricing mechanisms. CCEE is currently testing a new spot market pricing mechanism with hourly prices. Since 2017, there has been several discussions among regulators and market participants to replace the existing weekly pricing mechanism based on different load levels and adopt a daily pricing mechanism with hourly granularity. Such mechanism would generate accurate price signals to reflect the real system operation cost and better allocate the system costs among different market participants while boosting flexibility and efficiency in the electricity sector. 
This new pricing mechanism is currently being tested by CCEE and is expected to be officially implemented in 2021 (CCEE 2019c).

\subsubsection{Natural Gas Sector Policy Options}

Investments in Domestic Production: Brazil has high expectations for greater natural gas production, especially from the Pre-Salt fields which have already attracted many investments. In February of 2019, Shell, Patria Investments, and Mitsubishi Hitachi Power Systems announced the construction of the $565 \mathrm{MW}$ Marlim Azul gas power plant that will be supplied by Pre-salt gas produced by Shell Brazil, which is the second-largest natural gas producer in Brazil after Petrobras (PATRIA, 2019). Future production is still uncertain, but further investments on natural gas exploration and production could help the country to address technical challenges and boost the power generation sector with greater flexibility.

Robust and Competitive Market: Brazil has been working on a new gas market aimed to promote competition and reduce the state monopoly held by Petrobras. Text Box 8 describes two recent government initiatives in this direction. 


\section{Text Box 8. 'Gas to Grow' and 'New Gas Market' Initiatives in Brazil}

In 2016, President Michel Temer's administration launched the 'Gas to Grow' initiative that aimed to overhaul the natural gas regulatory framework in Brazil, improving tax rules and the integration between the electricity and gas sectors, with the goal of promoting competition and lowering prices by opening the gas market to new participants and reducing the existing control of Petrobras over the gas sector in Brazil (Figure 44).

\begin{tabular}{|c|c|c|}
\hline & Before & 'Gas to grow' Program \\
\hline \multirow{5}{*}{ Transmission pipelines } & $\begin{array}{l}\text { Capacity hired point-to-point } \\
\text { based on long-term contracts }\end{array}$ & Formation of entry-exit systems \\
\hline & Legal unbundling & $\begin{array}{l}\text { Ownership unbundling for new } \\
\text { Transmission System Operators }\end{array}$ \\
\hline & $\begin{array}{c}\text { Operation coordinated by } \\
\text { Petrobras }\end{array}$ & $\begin{array}{c}\text { Operation coordinated by } \\
\text { Independent Market Area } \\
\text { Manager }\end{array}$ \\
\hline & $\begin{array}{l}\text { Auctions for new pipelines and } \\
\text { expansions (concessions) }\end{array}$ & $\begin{array}{l}\text { Auctions for new pipelines and } \\
\text { expansions (authorization/permit) }\end{array}$ \\
\hline & $\begin{array}{l}\text { 10-year planning published by } \\
\text { MME based on EPE studies }\end{array}$ & $\begin{array}{l}\text { Indicative planning by EPE + } \\
\text { investment planning submitted by } \\
\text { TSOs and approved by ANP }\end{array}$ \\
\hline Distribution & $\begin{array}{l}\text { Open market regulated by each } \\
\text { state }\end{array}$ & $\begin{array}{l}\text { Open market regulated by the } \\
\text { Federal government and states }\end{array}$ \\
\hline $\begin{array}{c}\text { Upstream infrastructure and LNG } \\
\text { terminals }\end{array}$ & No third-party access (TPA) & $\begin{array}{l}\text { Negotiated non-discriminatory } \\
\text { TPA based on good practices code }\end{array}$ \\
\hline Storage & Concession after auction & Authorization/Permit \\
\hline
\end{tabular}

Source: Adapted from IEA (2018)

Figure 44. Main changes of the 'Gas to grow' program

The initiative was submitted to the Brazilian congress, but the house has not moved forward with the project due to the lack of external consensus among representatives of the natural gas sector. In December of 2018, President Michel Temer published an executive order introducing a pipeline capacity contracting scheme based on entry-exit model and allowing the Brazilian National Agency of Petroleum, Natural Gas, and Biofuels (ANP) to regulate the access to and sharing of the essential infrastructure (gas pipelines, natural gas processing units, and regasification facilities). Since Jair Bolsonaro took office as president of Brazil in January 2019, there have been several discussions on the development of a new regulatory framework for the natural gas market in Brazil. In June of 2019, the National Council for Energy Policy (CNPE) - which is linked to the Ministry of Mines and Energy (CNPE 2019) - published a resolution with the main guidelines to stimulate greater competition in the Brazilian natural gas market. In July of 2019, Bolsonaro's administration launched the 'New Gas Market' program, which aims to open the market to new participants and reduce the monopoly of Petrobras over natural gas exploration, production, transmission, and distribution in order to stimulate competition and, potentially result in higher production, lower prices, and better services for final consumers (MME 2019a).

Pipeline Infrastructure Expansion and Underground Storage: About 95\% of the Pre-Salt natural gas production centers are more than 90 miles from the shore (Coelho 2019) which calls for investments in offshore pipelines. In addition, the development of underground storage facilities could contribute to greater security of supply and reduce the dependency on imports for the power generator sector (Almeida et al. 2018). According to a preliminary study conducted by EPE, underground storage could ensure the security of natural gas supply in Brazil in adverse situations. In addition, the synergy between LNG terminals and underground gas storage 
facilities could lead to a greater operational flexibility of the Brazilian gas pipeline infrastructure (EPE 2018f).

Import Diversification and Flexible LNG Contracts and Technologies: Despite expectations of greater domestic production from the Pre-salt fields, LNG will still play a big role for power generation in the coming years in Brazil, mainly due to the flexibility provided by FSRUs, which can store LNG and re-gasify it when needed. In addition, the recent LNG market trends toward increased flexibility, fungibility, and commoditization, described in Section 3 may stimulate greater competition, thus leading to lower prices and additional benefits to LNG buyers like Brazil. Brazil's regasification capacity is expected to increase in about 60 million $\mathrm{m}^{3} /$ day in the next years with the development of new LNG-to-power projects, thus allowing the country to acquire LNG through long-term contracts (in addition to the current purchases in the spot market). Two new private FSRU terminals (Porto do Açu in the state of Rio de Janeiro and Barra dos Coqueiros in the State of Sergipe) are planned to be constructed and start operating within the next 5 years. Such terminals will import LNG through long-term contracts to supply natural gas to three new LNG-to-power projects with nearly $4.5 \mathrm{GW}$ of total installed capacity (UTE Porto de Sergipe, UTE GNA I, and UTE GNA II). However, there is no current plan to connect these terminals to the country's interconnected gas pipeline system.

\section{Summary}

Brazil has a great potential for increased power system flexibility and further policy development in both electricity and natural gas sectors. The country has already been promoting interesting initiatives in both sectors, which could serve as a reference for other South American countries.

\section{References for Section 5}

ANEEL. 2019. "Brasil ultrapassa marca de 1GW em geração distribuída." Accessed June 2019: https://tinyurl.com/yh7dfbyl

ARGUS. 2019. "Petrobras Expects Bolivian gas for 2-4 yrs more." Accessed April 2019: https://www.argusmedia.com/en/news/1872977-petrobras-expects-bolivian-gas-for-24-yrs-more

Brazilian National Agency of Petroleum, Natural Gas, and Biofuels (ANP). 2019a. "Boletim Mensal de Acompanhamento da Industria de Gas Natural.” Accessed February 2019: http://www.mme.gov.br

Brazilian National Agency of Petroleum, Natural Gas, and Biofuels (ANP). 2019b. "Anuário Estatístico." Accessed June 2019: http://www.anp.gov.br/publicacoes/anuario-estatistico

Cavalcanti, J. R. U.; De Almeida, E. L. F.; et al. 2018. "Economic value of underground natural gas storage for the Brazilian power sector," Energy Policy, vol. 121, pp. 488-497.

CCEE. 2019a. "Ambiente Livre e Ambiente Regulado.” Accessed March 2019:

https://www.ccee.org.br/portal/faces/pages_publico/como-participar/ambiente-livre-ambienteregulado? afrLoop $=24079833790598 \&$ adf.ctrl-state $=\mathrm{p} 4 \mathrm{~h} 771 \mathrm{tlk} \_1 \# ! \% 40 \% 40 \% 3 \mathrm{~F}$ afrLoop \%3D24079833790598\%26_adf.ctrl-state\%3Dp4h771tlk_5 
CCEE. 2019b. "Busca de Preços.” Accessed June 2019:

https://www.ccee.org.br/portal/faces/pages_publico/o-que-fazemos/como_ccee atua/precos/ historico preco semanal? afrLoop $=320884366559464 \&$ adf.ctrl-state=14kihixsxq 14\#! $\% 40 \% 40 \% 3 \mathrm{~F}$ afrLoop $\% 3 \mathrm{D} 320884366559464 \% 26$ adf.ctrl-state\%3D14kihixsxq 18

CCEE. 2019c. "Preço Horário 'Sombra’". Accessed June 2019: https://www.ccee.org.br/portal/faces/pages publico/o-que-fazemos/como ccee atua/precos/ preco sombra? afrLoop $=1193301608447883 \&$ adf.ctrl-state $=8$ yliju $51 \mathrm{~h} \quad 22 \# ! \% 40 \% 40 \% 3 \mathrm{~F}$ afrLoop\%3D1193301608447883\%26 adf.ctrl-state\%3D8yliju51h 26

CNPE. 2019. "Resolução Numero 16, de 24 de Junho de 2019." Accessed August 2019: http://www.mme.gov.br/documents/10584/3342640/1.+Resolu\%C3\%A7\%C3\%A3o_CNPE 16 2019.pdf/c66fb3a3-6265-427f-a56a-f6730e6a80de

Coelho, J. M. 2019. “Desafios da oferta nacional de gás natural,” Accessed August 2019: http://www.epe.gov.br/sites-pt/sala-de-imprensa/noticias/Documents/EPE 19\%c2\%ba\% 20SEMIN\%c3\%81RIO\%20SOBRE\%20G\%c3\%81S\%20NATURAL DESAFIOS\%20DA\%20O FERTA\%20DE\%20G\%c3\%81S JOS\%c3\%89\%20MAURO 20190814\%281\%29.pdf

Da Silva, L. L. 2007. "The electricity generation sector in Brazil: The perception of regulatory and environmental risk," Washington, DC: The George Washington University.

EPE. 2018a. "Plano Decenal de Expansão de Energia 2027." Accessed February 2019: http://www.epe.gov.br/pt/publicacoes-dados-abertos/publicacoes/plano-decenal-de-expansao-de$\underline{\text { energia-2027 }}$

EPE. 2018b. "Potencial dos Recursos Energéticos no Horizonte 2050.” Accessed March 2019: http://www.epe.gov.br/sites-pt/publicacoes-dados-abertos/publicacoes/PublicacoesArquivos/ publicacao-227/topico-416/NT04\%20PR RecursosEnergeticos\%202050.pdf

EPE. 2018c. "Design and implementation of reverse auction - Case study of Brazil." SAARC Knowledge Sharing Workshop on Modern Techniques Including Renewable Energy Auctions for Economizing Renewable Energy Tariff, May 10, 2018.

EPE. 2018d. "International LNG Market: Impacts on Brazil.” Accessed November 2018: http://www.epe.gov.br/sites-en/publicacoes-dados-abertos/publicacoes/Publicacoes Arquivos/publicacao-183/LNG\%20International\%20Market\%20Report\%202018-2027 rev1.pdf

EPE. 2018e. "Flexibilidade e Capacidade: Conceitos para a incorporação de atributos ao planejamento." Accessed April 2019: http://www.epe.gov.br/sites-pt/publicacoes-dadosabertos/publicacoes/PublicacoesArquivos/publicacao-316/NT_EPE_DEE-NT-067_2018-r0.pdf

EPE. 2018f. "Estocagem Subterrânea de Gás Natural - Aspectos Gerais, Regulatórios, Estimativa de Custos e Simulação." Accessed November 2019: http://www.epe.gov.br/pt/publicacoesdados-abertos/publicacoes/estocagem-subterranea-de-gas-natural-aspectos-gerais-regulatoriosestimativa-de-custos-e-simulacao 
EPE. 2019a. "Balanço Energético Nacional.” Accessed January 2019:

http://www.epe.gov.br/sites-pt/publicacoes-dados-abertos/publicacoes/PublicacoesArquivos/ publicacao-303/topico-419/BEN2018_ Int.pdf

EPE. 2019b. “Comparações de Preços de Gás Natural: Brasil e Países Selecionados.” Accessed June 2019: http://epe.gov.br/sites-en/publicacoes-dados-abertos/publicacoes/Publicacoes Arquivos/publicacao-193/INFORME\%20-\%20Compara\%C3\%A7\%C3\%B5es\%20de\%20Pre\% C3\%A7os\%20de\%20G\%C3\%A1s\%20Natural.pdf

EPE. 2019c. "Demand Response: Concepts, Regulatory Aspects and Energy Planning." Accessed April 2019: http://epe.gov.br/sites-en/publicacoes-dadosabertos/publicacoes/Publicacoes Arquivos/publicacao-194/NT_EPE_DEE-NT-024_2019r0_Ing $1 \% \mathrm{C} 3 \%$ AAs.pdf

EPE. 2019d. "Estudos de Inventário de Usinas Hidrelétricas Reversíveis.” Accessed May 2019: http://www.epe.gov.br/sites-pt/publicacoes-dados-abertos/publicacoes/PublicacoesArquivos/ publicacao-353/EPE-DEE-NT-006_2019-r0.pdf

Fearnside, P. 2017. "How a dam building boom is transforming the Brazilian Amazon," Accessed November 2019: https://e360.yale.edu/features/how-a-dam-building-boom-istransforming-the-brazilian-amazon

International Energy Agency (IEA). 2018. "Towards a Competitive Natural Gas Market in Brazil - A Review of the opening of the natural gas transmission system in Brazil," OECD/IEA, Paris.

International Energy Agency (IEA). 2019. “Statistics.” Accessed November 2019.

International Group of Liquefied Natural Gas Importers (GIIGNL). 2019. "The LNG Industry GIIGNL Annual Report 2019.” Accessed May 2019: https://giignl.org/sites/default/files/ PUBLIC_AREA/Publications/giignl_annual_report_2019-compressed.pdf

Mastropietro, P.; Batlle, C.; et al. 2016. "The evolution of electricity auctions in South America," Energy Sources, Part B: Economics, Planning, and Policy, vol. 11, no. 12, pp. 1103-1110, 2016.

MME. 2019. "Governo lança o 'Novo Mercado do Gás', um marco histórico para o Brasil." Accessed August 2019: http://www.mme.gov.br/web/guest/pagina-inicial/outras-noticas/asset publisher/32hLrOzMKwWb/content/governo-lanca-o-novo-mercado-do-gas-um-marcohistorico-para-o-brasil

National Confederation of Industry (CNI). 2018. "Térmicas na base: a escolha inevitável." Accessed May 2019: https://bucket-gw-cni-static-cmssi.s3.amazonaws.com/media/filer public/f7/33/f733ead5-921a-48d0-be45-a474396f5a00/29 termicas_na_base.pdf

ONS. 2019. "Histórico da Operação." Accessed June 2019: http://ons.org.br/Paginas/resultadosda-operacao/historico-da-operacao/geracao_energia.aspx 
ONS and CCEE. 2018. " $1{ }^{\circ}$ Relatório de Análise do Programa Piloto de Resposta da Demanda." Accessed June 2019: http://ons.org.br/AcervoDigitalDocumentosEPublicacoes/201812_ONS CCEE_Relatorio\%20Programa\%20Piloto\%20Resposta\%20Demanda.pdf

Oxford Institute for Energy Studies (Oxford). 2016. "South American Gas Markets and the Role of LNG," Oxford, UK.

PATRIA. 2019. "Pátria Investimentos, Shell e Mitsubishi Hitachi Power Systems anunciam sociedade em termoelétrica." Accessed February 2019: https://www.patria.com/media/pressreleases/patria-investimentos-shell-e-mitsubishi-hitachi-power-systems-anunciam-sociedade-emtermoeletrica 


\section{Chile}

\subsection{Electricity Sector Overview}

This section provides an overview of the Chilean electricity sector, briefly describing its history, organization, and development.

\subsubsection{Market Liberalization and Privatization}

Chile was the first country in the world to restructure its electricity sector towards liberalization and privatization (Houllier et al. 2012). The traditional vertically integrated monopoly model in generation, transmission, and distribution was dismantled and, in 1986, the Center for Economic Load Dispatch (CDEC) of Chile was created to perform centralized generation dispatch based on marginal cost pricing (Pollitt 2004). In 1992, the country enacted the 'Electricity Act', which promoted the privatization of state-owned companies, introduced market competition, and opened the electricity sector to new participants aiming to attract investments to the sector (Mastropietro et al. 2016).

\subsubsection{Installed Capacity and Generation Mix}

Between 2008 and 2018, the Chilean power sector has seen a doubling of generation capacity, largely due to new coal, wind and solar plants (Figure 45). Total hydropower capacity increased slightly, but its share of the total declined significantly due to the growth in other generating supply.

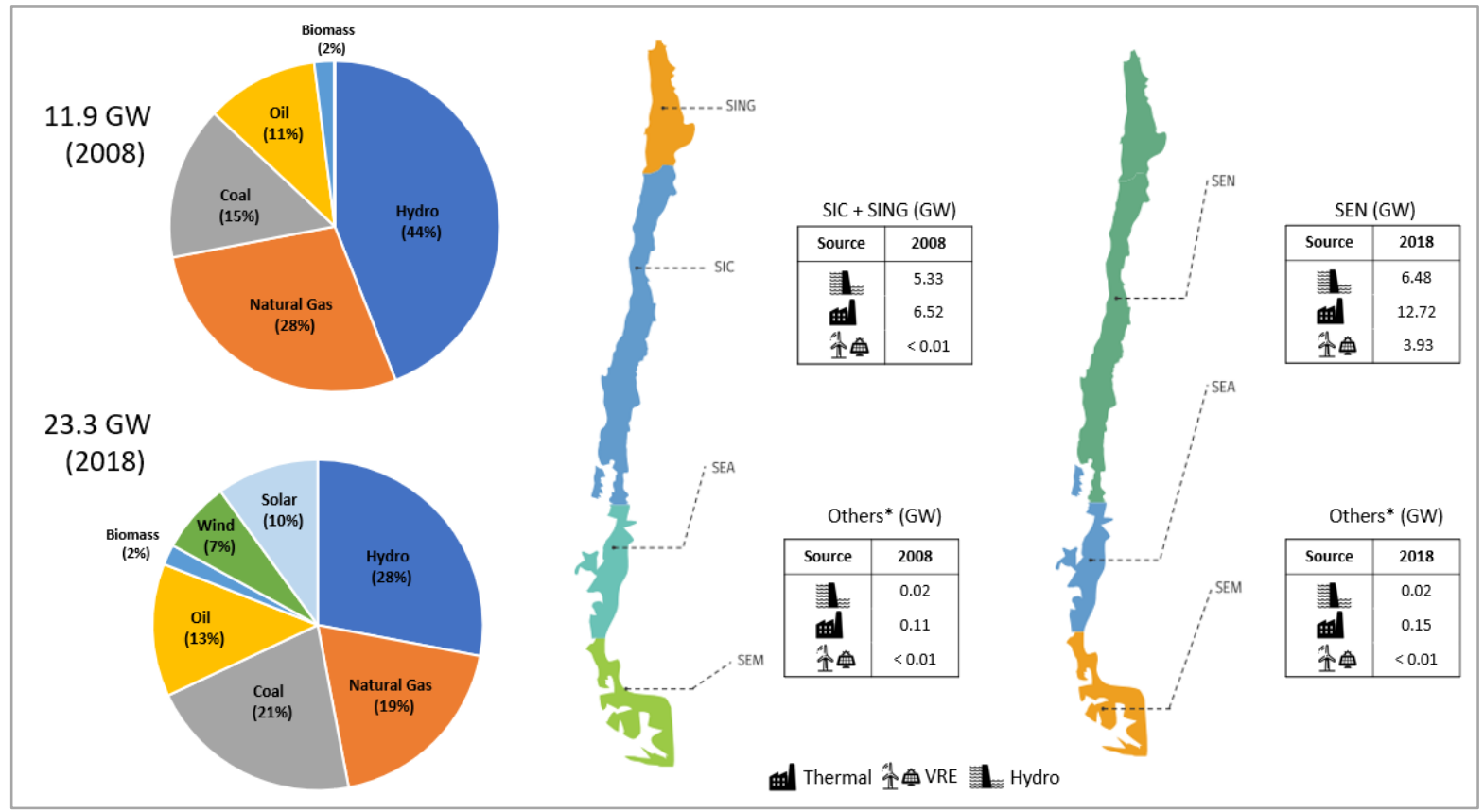

Source: Data from CNE (2019a)

Figure 45. Total and regional installed capacity in Chile in 2008 and 2018

* Includes SEA, SEM, and the isolated systems of Los Lagos and Isla de Pascua. 


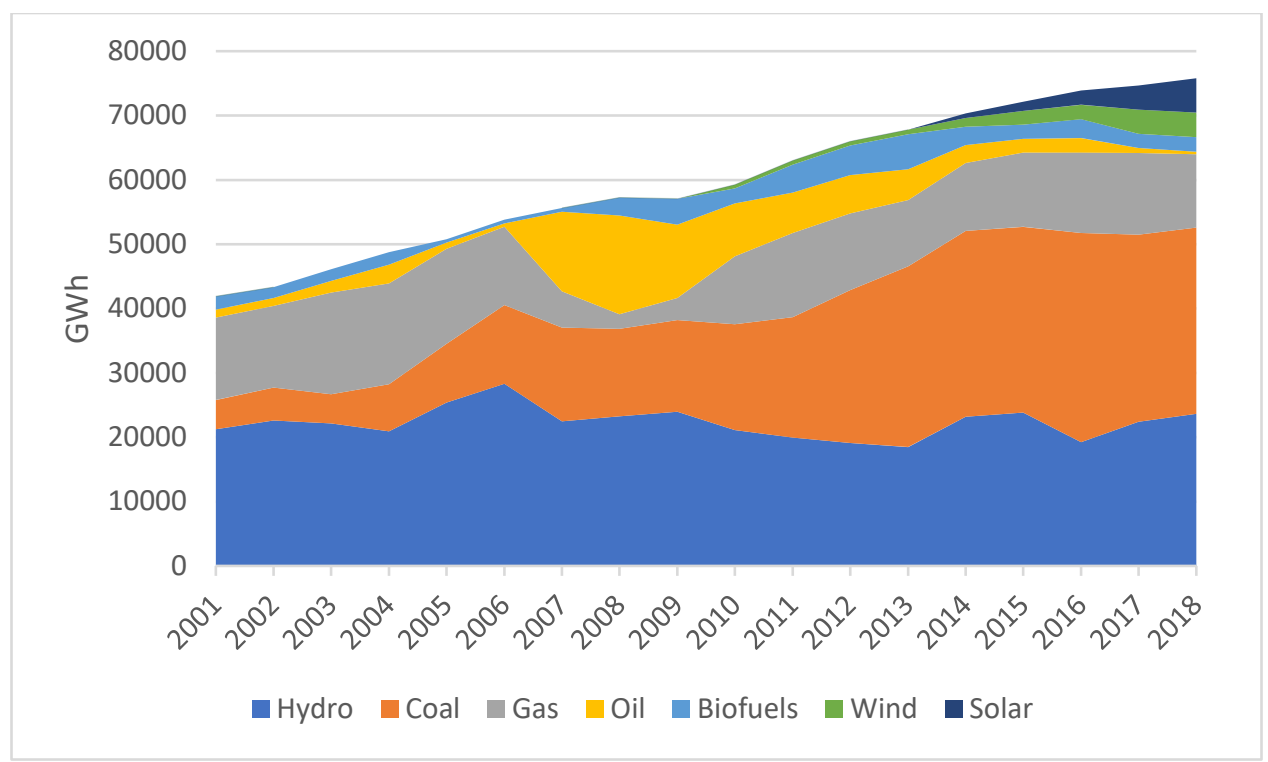

Source: Data from IEA (2018) and CNE (2019a)

Figure 46. Electricity generation mix in Chile from 2001 to 2018

Likewise, the Chilean generation mix has changed significantly over the last two decades, with basically flat levels of hydropower output, rapid increases in coal generation, and varying levels of gas, and oil generation, as shown in Figure 46. Wind and solar generation have grown especially rapidly since 2014 . The Chilean power generation sector is highly concentrated. The country has more than 160 generation companies, but most of them are subsidiaries of four major companies (IEA 2018a).

\subsubsection{Hydropower decline}

Hydropower has been historically an important electricity generation source in Chile. In the mid 2000 's, hydropower plants accounted for more than 50\% of the country's generation mix. However, the public opposition to the construction of such plants, due to their socioenvironmental impacts, has been increasing significantly in recent years, thus leading investors to look at generation options with lower environmental impacts and initial investment costs. In 2018 , hydropower accounted for about only $30 \%$ of the Chilean generation mix, partially as a consequence of several years of drought.

\subsubsection{The Growth of Gas-fired Generation and the Impacts of the Argentina Gas Crisis}

In the late 1990s and early 2000s, Chile imported significant amounts of pipeline natural gas from Argentina and natural gas rapidly became the country's second largest source of electricity generation after hydropower. In 2003, natural gas accounted for about $35 \%$ of Chile's electricity generation (IEA 2018). From 2004-07, however, Argentina faced a severe natural gas crisis (see Section 4) which forced the country to drastically reduce its natural gas exports. The curtailment of natural gas exports by Argentina had serious implications for the electricity sector in Chile, leading the Chilean government to intervene on a deregulated and privatized electricity sector. The shortage of natural gas combined with the severe droughts in 2007-2008 led Chile to resort to expensive liquid fuels as a short-term solution to fill its electricity generation gap (IEA 2018b). According to Chile's National Energy Commission (CNE), the oil-fired electricity 
generation increased from less than 1 TWh in 2006 to more than 12 TWh in 2007 (CNE 2019a). In 2005, a regulatory reform was introduced to replace the existing contracts under price regulation with long-term contracts established through auctions (Bustos-Salvagno, 2019). This reform aimed to attract investments to expand the existing generation capacity, reduce price volatility, and ensure the security of supply. In the early 2010 's, gas-fired generation grew again, mainly due to the commissioning of two LNG regasification terminals. The Argentina gas crisis also led the Chilean government to foster VRE (see Section 6.1.2.4) as an option to diversity the country's generation mix and reduce the overall marginal cost of generation.

\subsubsection{The Rise and Decline of Coal-fired Generation}

Following the Argentina natural gas crisis in the mid 2000's, Chile faced a significant natural gas shortage, especially in the power generation sector. As a consequence, the country resorted to coal power generation to ensure the security of electricity supply and limit the use of expensive liquid fuels (IEA 2018), thus becoming the most-coal dependent power system in South America. The coal power installed capacity increased from about $1.8 \mathrm{GW}(18 \%)$ in 2005 to more than $4.3 \mathrm{GW}(22 \%)$ in 2015 . In addition, the annual capacity factor of many coal-fired power plants increased significantly in the same period. In 2015, for example, coal -fired power plants accounted for $22 \%$ of Chile's installed capacity, but they generated about $40 \%$ of the country's electricity (CNE 2019a).

In January of 2018 the group of generating companies that own all coal power plants in Chile made a voluntary agreement with the Chilean government to stop developing new coal power generation projects without carbon capture and storage systems (CCSs) and gradually decarbonize (by retiring existing plants or equipping them with CCSs) their generation mix (MMA 2018). In June of 2019, President Sebastian Piñera announced a plan to phase-out coalfired power generation in Chile by 2040. This initiative was mainly driven by the country's efforts to reduce greenhouse emissions, reduce air pollution, and meet the long-term renewable energy generation targets ( $60 \%$ by 2035 and $70 \%$ by 2050 ) (IEA 2018).

\subsubsection{The Increasing Integration of VRE}

Chile has integrated VRE generation capacity at a very fast rate. As shown in Figure 47, the VRE installed capacity increased from $1.2 \mathrm{GW}$ in 2014 to more than $3.6 \mathrm{GW} 2018$. As of July of 2019 , VRE accounted for more than $16 \%$ of the country's installed capacity. 


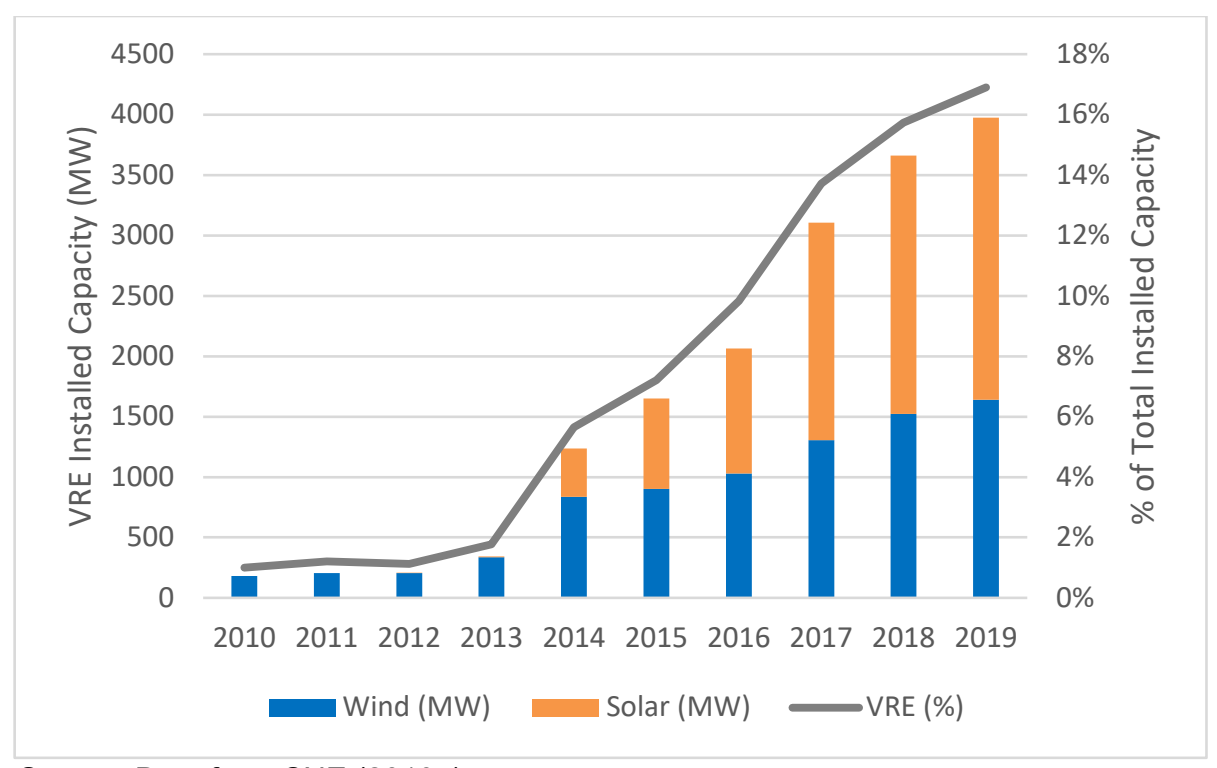

Source: Data from CNE (2019a)

Figure 47. VRE installed capacity in Chile from 2010 to July 2019

The move toward increasing VRE integration in Chile started in 2004 with Law 19,940 that granted total transmission charges exemption to various renewable energy projects with capacity below $9 \mathrm{MW}$ and partial exemption to projects with capacity between 9 and $20 \mathrm{MW}$ (Manríquez 2018). In 2008, the Non-Conventional Renewable Energy Law (NCRE Law 20,257) was enacted to boost NCRE sources. This law required utilities to acquire a certain amount of NCRE and established a goal of 10\% of NCRE generation by 2024. In 2013, Law 20,698 (also known as Law '20/2025') was enacted updating the NCRE generation goal to $20 \%$ by 2025 . In the following year, the government set a carbon tax of $\$ 5$ per ton of carbon dioxide emissions for power generators (Rypl 2018). In January of 2015, the government enacted Law 20,805 that introduced new rules to the technology-neutral electricity procurement auctions in Chile. The auctions were divided into several time blocks with long-term PPAs denominated in U.S. dollars awarded for each block (Rypl 2018). Such mechanism has reduced the risk exposure of VRE producers since they can bid on time blocks of higher expected generation and/or lower uncertainty. As a result, Chile has experienced a significant growth of wind and solar energy in recent years and such growth has helped the country to gradually solve some of its critical electricity sector problems such as the high electricity prices, low investment in new generation capacity, and the high dependency on fossil fuels (Rebolledo 2018).

The wind and solar energy potential in Chile is enormous. According to the Chilean Ministry of Energy and the German Agency for International Cooperation (GIZ) (Chilean Ministry of Energy and GIZ, 2014), there is a potential of more than $1800 \mathrm{GW}$ of solar power (about 548 GW of concentrated solar power (CSP) and $1263 \mathrm{GW}$ of solar photovoltaic), which is mostly located in the northern part of the country around the Atacama Desert (which has some of the highest and most consistent solar radiation levels on earth (Rebolledo 2018)), and $37 \mathrm{GW}$ of wind power, mostly located in the southern part of the country. However, most of this VRE potential in Chile remains untapped (Ministerio de Energía and GIZ 2014). 


\subsubsection{Consumption}

Chile's electricity consumption has increased significantly in the last years, mainly due to the country's economic growth. From 2008 to 2018, it increased over 30\%. Figure 48 shows Chile's peak demand evolution in the last ten years. In 2018, it reached 10.5 GW.

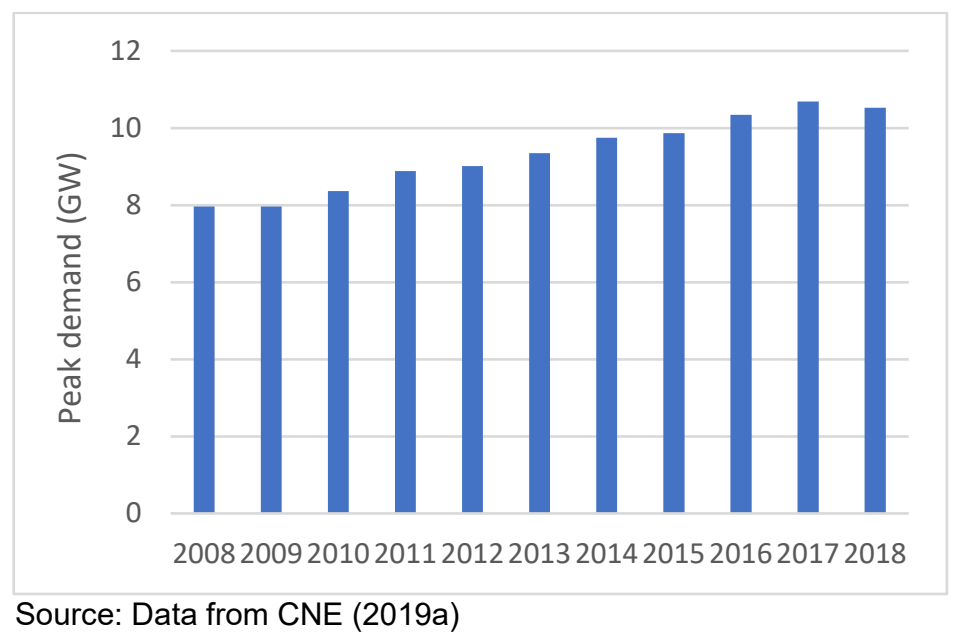

Figure 48. Chile's peak demand evolution from 2008 to 2018

\subsubsection{Transmission Infrastructure}

Chile has a unique geographical and social distribution that pose many challenges to its transmission planning and operation. The country occupies a nearly 2,500 miles long and about 125 miles narrow coastal strip with a variety of climates and terrains. However, the great majority of the population and the electricity demand is located in the central part of the country around the capital of Santiago. The Chilean transmission grid is currently composed of 3 interconnected systems. The National Electric System (SEN) extends from the north desert of Atacama to the central-south part of Chile and covers more than $98 \%$ of the country's population and installed capacity. The Aysen Interconnected System (SEA) and Magallanes Electric System (SEM) serve small and less populated areas in the extreme southern part of the country. Before November of 2017, SEN was divided into two separate systems: The Central Interconnected System (SIC), a hydrothermal system with large impoundment hydropower plants, and the Greater North Interconnected System (SING), with significant thermal power generation and mining load centers (Maluenda et al. 2018). With the interconnection of SIC and SING, the Chilean National Electricity Coordinator, can better explore the complementarity between wind and solar power in the north and hydropower in the south.

\subsection{Natural Gas Sector Overview}

Among the South American countries studied in this report, Chile has the lowest natural gas production, consumption, and proved reserves based on domestic resources. The country is also the most dependent on natural gas imports.

\subsubsection{Sector Organization}

The main government entities involved in the Chilean natural gas sector are the Ministry of Energy, which creates and coordinates policies and regulations for the sector, the National 
Energy Commission (CNE), which is responsible for analyzing tariffs and regulations, and the Superintendent of Electricity and Fuels (SEC), which is responsible for setting rules and standards and ensuring compliance with existing regulations (IEA 2018). In addition, the stateowned company ENAP is the main producer, importer, and marketer of natural gas in Chile.

\subsubsection{Consumption}

Chile's natural gas consumption fluctuated widely over the past twenty years. The increasing gas imports from Argentina in the late 1900's and early 2000's boosted domestic consumption in many sectors. In 2004, it peaked to $0.83 \mathrm{Bcf} /$ day. After Argentina's gas crisis in the mid 2000's, gas imports were drastically reduced, and Chile was forced to use LPG, coal, and diesel as substitutes for natural gas. Gas consumption in Chile consequently plummeted nearly $60 \%$ by 2008. In the early 2010 's, after the commission of two LNG regasification terminals, natural gas consumption began growing again, but at a lower rate. In 2018, Chile's gas consumption was around $0.46 \mathrm{Bcf} / \mathrm{day}, 61 \%$ higher than in 2008 , but $45 \%$ lower than in 2004 . Figure 49 shows the Chilean natural gas consumption by sector from 1990 to 2018.

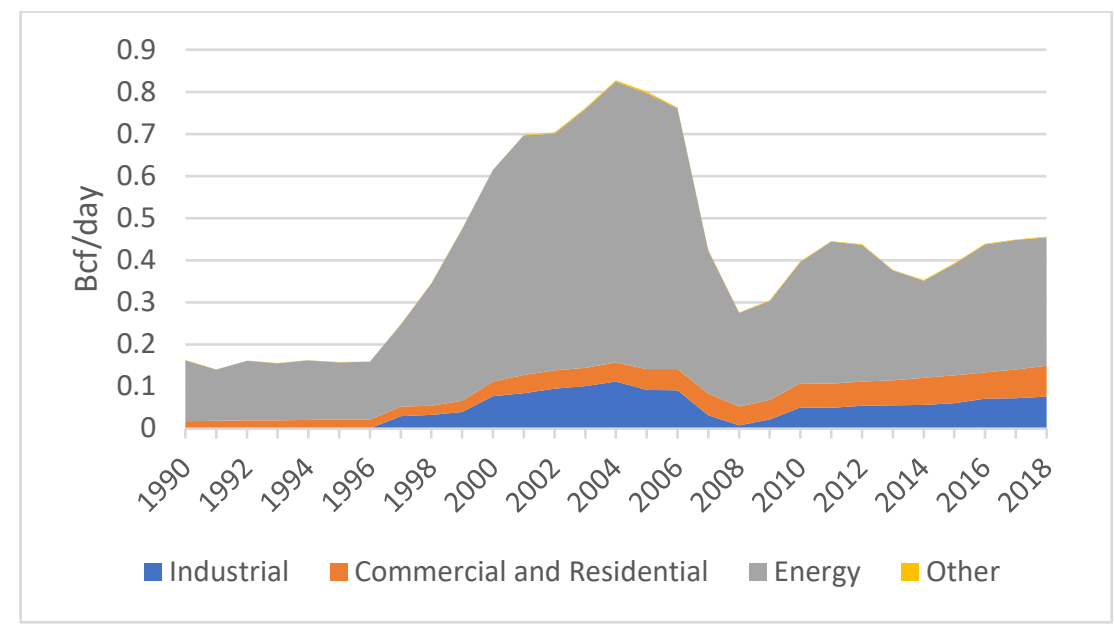

Source: Data from CNE (2019b)

Figure 49. Chilean natural gas consumption by sector

\subsubsection{Domestic Production and Imports}

Figure 50 shows the Chilean natural gas domestic production as well as pipeline gas and LNG imports from 2000 to 2018. 


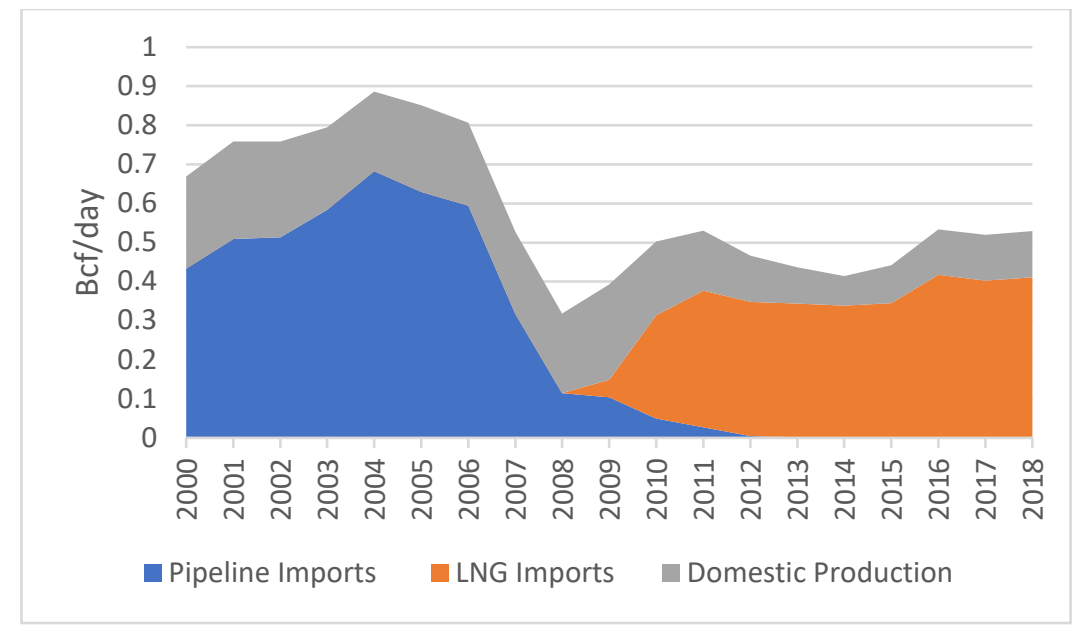

Source: Data from CNE (2019c)

Figure 50. Chilean natural gas production, pipeline imports, and LNG imports

\subsubsection{Domestic production}

As of 2018, Chile has only 0.16 Tcf of natural gas proven reserves (BP, 2019). The country produces small volumes of natural gas, mainly in the southern region of Magallanes, which consumes most of the country's domestic gas production for power generation and heating. In 2018 , domestic production accounted for only $25 \%$ of the gas supply. In Chile, natural gas exploration and production can only be carried out by ENAP or by private entities through concessions or binding agreements with the state (IEA 2018). From 2007 to 2018, ENAP produced more than $70 \%$ of the Chilean domestic natural gas.

\subsubsection{Pipeline Imports}

In 1997 Chile began to import natural gas from Argentina via pipeline and several pipelines were built between the two countries. By the mid 2000's the country had become heavily dependent on gas imports, especially for power generation. In the same decade, however, Argentina was struck by a severe gas crisis that forced the country to drastically reduce and eventually cut all gas exports to Chile, Brazil, and Uruguay. In 2018, Chile resumed importing small quantities of natural gas from Argentina during the periods of lower residential demand in Argentina.

\subsubsection{LNG Imports}

In response to the drastic reduction of gas exports via pipeline from Argentina, Chile built two onshore LNG regasification terminals. The Quintero LNG terminal, located in the central part of the country, was commissioned in 2009 and has a regasification capacity around $0.2 \mathrm{Bcf} /$ day. The Mejillones LNG terminal, located in the far north part of the country, was commissioned in 2010 and has a regasification capacity around 0.5 Bcf/day. Figure 51 shows Chile's LNG imports by country of origin. Chile has imported most of its LNG from Trinidad and Tobago since 2012. However, the LNG imports from the U.S. have increased in the last three years, reaching $25 \%$ of the total imports in 2018. 


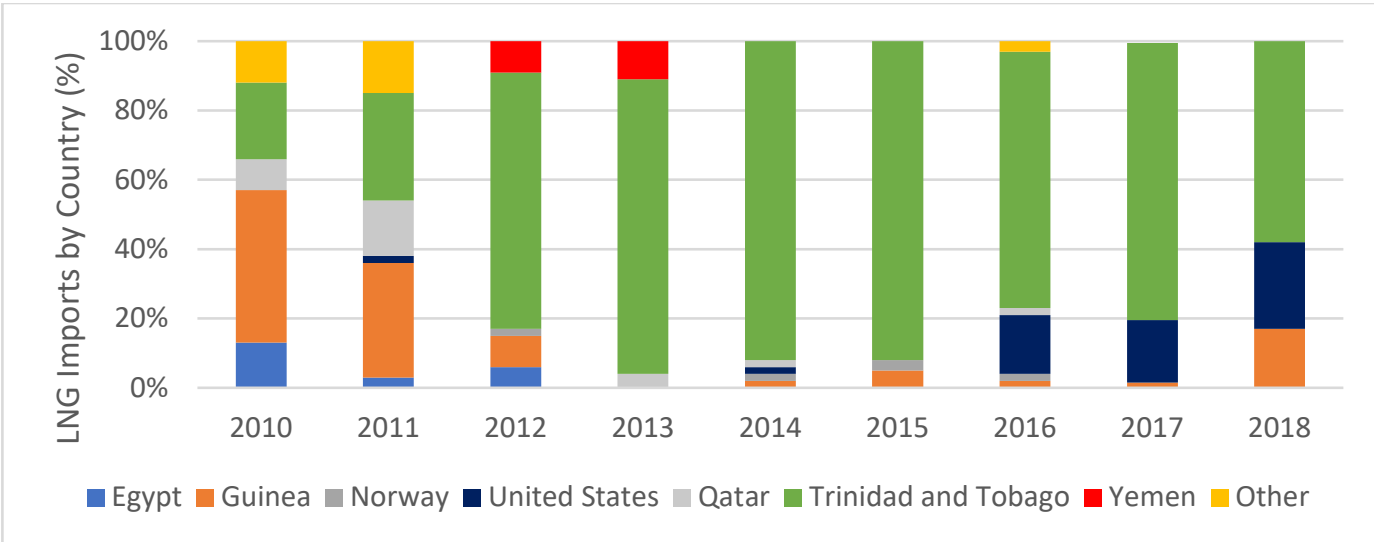

Source: Data from GIIGNL (2019) and CNE (2019c)

Figure 51. Chile's LNG imports by country of origin

\subsubsection{Exports}

Since 2016, Chile has exported small quantities of natural gas to Argentina, which is mostly used for power generation, through winter-season contracts that allow Chile to import and re-gasify LNG and use the existing cross-border pipelines to export it to Argentina (IEA 2018).

\subsubsection{Pipeline infrastructure}

Chile's natural gas network is regionally disconnected given the country's longitudinal extension. The Quintero and Mejillones LNG terminals supply most of the natural gas consumed in the central and northern regions. The southern region is mostly supplied by local production from the Magallanes region (IEA 2018).

\subsection{Power System Flexibility}

\subsubsection{Sources of Flexibility}

The main sources of existing flexibility in Chile are impoundment hydropower plants (medium and long-term), run-of-the-river power plants (short-term), thermal power plants such as coal (medium and long-term) and gas-fired (short, medium, and long-term). The country's first CSP plant with energy storage is expected to be commissioned in late 2019 and will provide dispatchable power around the clock (Helioscsp 2019). Like Argentina and Brazil, Chile has also diversified its generation mix with VRE, which has enhanced the country's long-term flexibility.

\subsubsection{Drivers of the Need for Flexibility}

\subsubsection{Rainfall Variability}

The seasonal and occasional fluctuations in hydropower supplies, mostly related to variations in rainfall caused by weather patterns can significantly jeopardize the system's flexibility at different time scales. Since 2007, Chile has been suffering from severe droughts that have significantly reduced its hydropower production as well as the storage capacity in the main reservoirs. According to the World Resources Institute (WRI 2015), Chile will be among the 25 most water-stressed countries in the world by 2040. Figure 52 shows the storage capacity (GWh) reduction in the main Chilean reservoirs in the last two decades. 


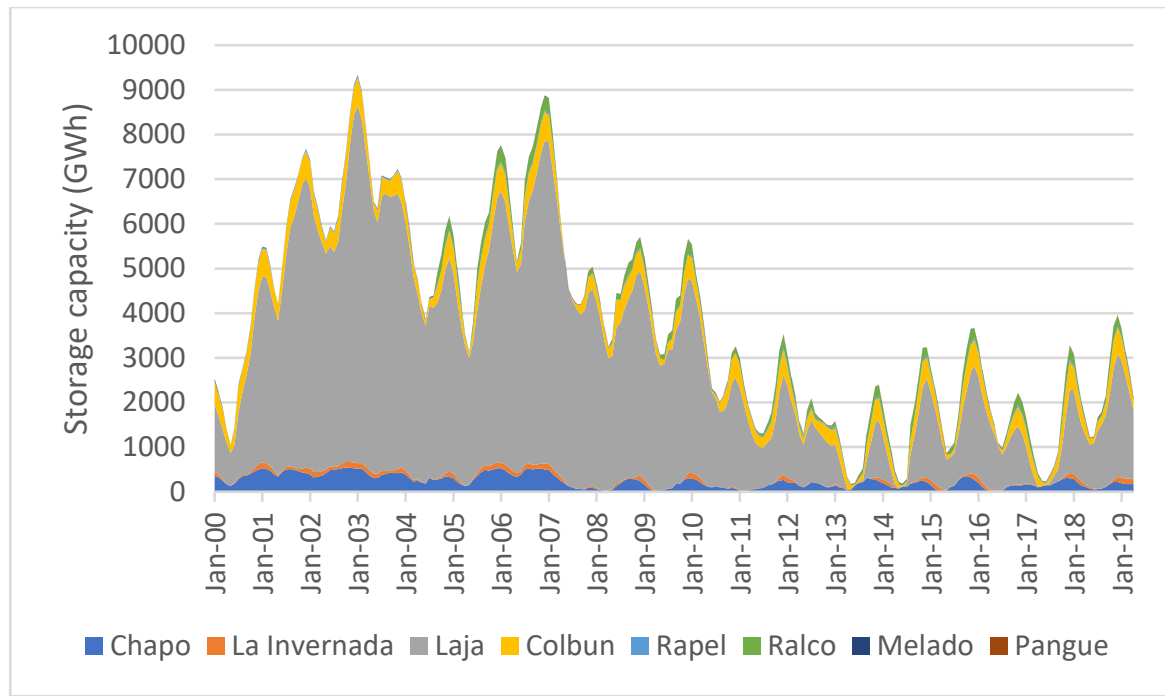

Source: Data from Systep (2019)

Figure 52. Storage capacity in the main Chilean reservoirs

In some regions of Chile, the impacts of long-term droughts have been significantly intensified during La Niña events. Figure 53 shows how the intense La Niña events of 2007-2008, 2011 2013, and 2016-2018 affected the storage capacity $\left(\mathrm{m}^{3}\right)$ in the Colbún Dam, one of the largest reservoirs in Chile, located in the central part of the country.

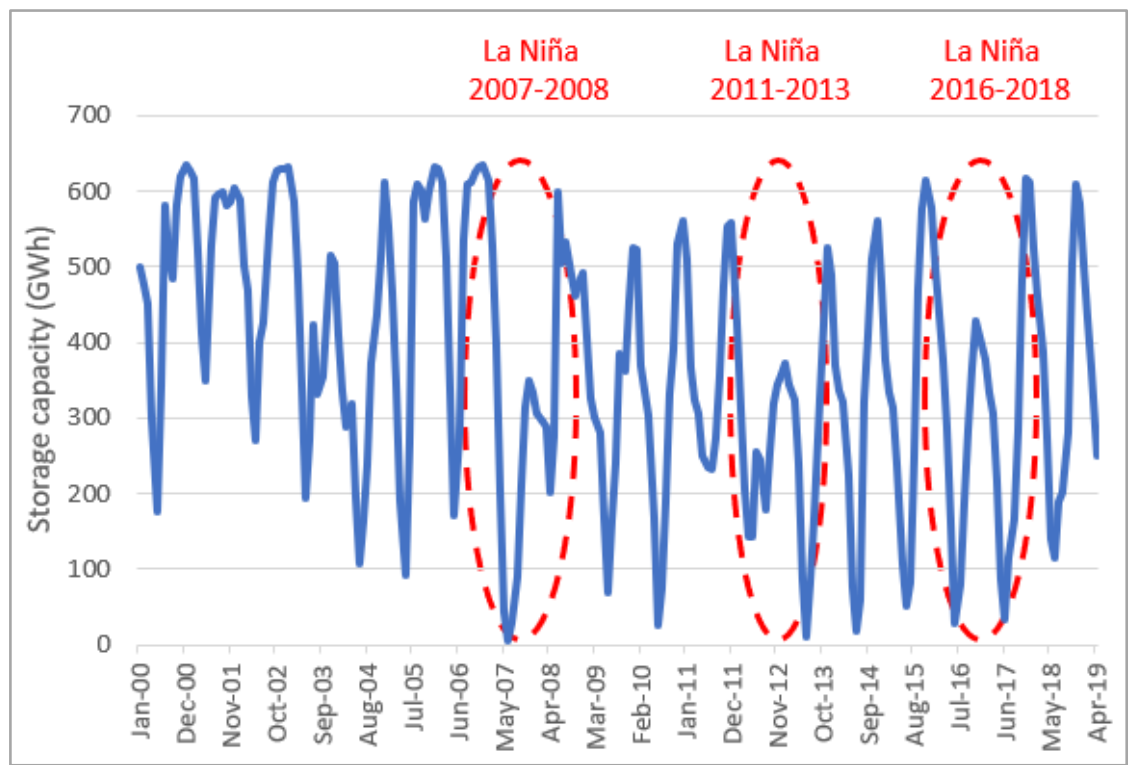

Source: Data from Systep (2019)

Figure 53. Storage capacity in the Colbún Dam

\subsubsection{Public Opposition to Hydropower Plants}

Like Brazil and Colombia, Chile has also relied on large impoundment hydropower plants for the provision of storage and flexibility services at low operational and opportunity costs (Moreno et al. 2017). Due to various socio-environmental challenges associated with the construction of new large reservoirs, the country has also been exploiting its hydropower potential through run-of- 
the-river projects. Table 7 shows the SEN hydropower capacity (in GW and as percentage of the total hydropower installed capacity) by type of power plant in 2008 and 2018, respectively. The run-of-the-river power plants, which accounted for only $36 \%$ of the total hydropower capacity in 2008, now account for more than two thirds of the Chilean hydropower capacity, thus posing increasing challenges to the provision of medium and long-term flexibility.

Table 7. SEN Hydropower Capacity

\begin{tabular}{|c|c|c|}
\hline Hydropower plant & 2008 & 2018 \\
\hline Run-of-the-river & $1.9 \mathrm{GW}(36 \%)$ & $6.7 \mathrm{GW}(68 \%)$ \\
\hline Impoundment (large reservoirs) & $3.4 \mathrm{GW}(64 \%)$ & $3.2 \mathrm{GW}(32 \%)$ \\
\hline
\end{tabular}

Source: Data from CNE (2019b)

\subsubsection{Growing VRE Integration}

The rapid growth of VRE capacity in Chile has posed challenges that go beyond the well-known short-term flexibility concerns. The lack of transmission and storage infrastructure has already led to oversupply and, consequently, the curtailment of VRE in some regions ${ }^{9}$ (IEA 2018). The recent interconnection of the SIC and SING systems represent an important step to improve the operation of the system. However, the country lacks transmission lines to carry wind and solar power from remote areas to the main consumption centers, and storage systems to better utilize wind and solar power at different times.

\subsubsection{Thermal Power Inflexibility}

Like Argentina, Chile has many thermal power plants that provide limited, costly flexibility services. The increasing integration of VRE in Chile has impacted the flexibility operation of many thermal power plants. In order to maximize generation from VRE sources, thermal power plants are operating with lower capacity factors and their cycling (number of start-ups/shutdowns and ramp up/down) has increased significantly in recent years (Generadoras de Chile 2017). Recent studies on flexibility in Chile indicate an expected increase in cycling of thermal power plants for different VRE integration scenarios, which may imply additional operation and maintenance costs for thermal power producers and electricity price fluctuations (Maluenda et al. 2018; PSR and Moray 2018). According to a study commissioned by the Chilean Generators Association and conducted by PSR and Moray (PSR and Moray 2018), the flexibility (mostly cycling) costs of thermal power plants in Chile could reach nearly US\$350 million in 2030.

\subsection{Key Policy Options to Enhance Flexibility in Chile}

Chile has been working to define effective strategies to enhance its power system flexibility (Electricidad 2019). This section provides some key policy option as well as some recent efforts in both electricity and natural gas sectors to enhance the country's power system flexibility.

\footnotetext{
${ }^{9}$ In some cases, curtailment of VRE generation can be the least-costly way to provide increased flexibility.
} 


\subsubsection{Electricity Sector Policy Options}

Generation Mix Diversification and Distributed Energy Resources (DERs): The increasing integration of VRE sources has contributed to the diversification of the Chilean electricity mix. With the plan to gradually retire all its coal-fired power plants over the next 20 years, Chile needs to find additional sources of flexibility that can be operated in efficient and economic ways. Distributed generation, for example, is an option to reduce the dependency on centralized generation options and help the country mitigate its transmission system limitations.

Effective Pricing Mechanisms / Demand Side Management: Chile lacks a regulatory framework and market-based incentives focused on demand side management for consumers at wholesale and retail level. In the wholesale market, for example, there are opportunities to integrate demand-response mechanisms in the spot, capacity, and balancing markets (Valdes et al. 2019) to provide technical and economic benefits to the grid such as the reduction of costly thermal power cycling. Demand-response implementation in the mining sector, for example, and other sectors of the economy, could save millions of dollars in operations costs and defer investments in new generation plants (Morales et al. 2015).

Storage Systems and Interconnections: Investments in energy storage technologies such as batteries, pumped storage, and thermal storage systems associated with CSP plants are essential to mitigate VRE uncertainties and enhance short-term flexibility in Chile. The expansion and upgrade of the existing transmission infrastructure is also essential to deliver VRE from remote areas, such as the Atacama Desert, to the main consumption centers and to better supply the mining load centers in the northern regions for night-time operations. Chile also lacks international interconnections with its neighboring countries (Peru, Bolivia, and Argentina). Such interconnections would allow the country to enhance its power system flexibility through electricity imports and exports when needed. A recent study conducted by the Chilean National Electricity Coordinator highlights the importance of transmission expansion as well as the increasing role of other generation options such as natural gas, pumped storage, and CSP for the provision of flexibility in Chile (Chilean National Electricity Coordinator 2018).

\subsubsection{Natural Gas Sector Policy Options}

Import Diversification and Flexible LNG Contracts and Technologies: Chile is expected to expand LNG imports at least in the short and medium terms as gas-fired power plants become an increasingly important option to fill the future generation gap to be left by retiring coal-fired power plants and mitigate the variabilities of hydropower, wind and solar output. Two new regasification terminals (Penco-Lirquen and Talcahuano) are planned to be constructed. Both projects, however, have suffered significant delays to obtain all necessary approvals and licenses for their construction (EPE 2018). Greater gas imports via pipeline from Argentina may also help Chile to diversify its natural gas supply. However, it will depend on Argentina's capacity to export natural gas on a consistent and reliable basis.

\section{Summary}

Chile has significant flexibility challenges to be addressed in the coming years. In the electricity sector, policy options range from generation mix diversification to international interconnections. Different from the other countries considered in this report, Chile's policy options in the natural gas sector are restricted to pipeline and LNG imports due to the country's small natural gas reserves and domestic production. 


\section{References for Section 6}

BP. 2019, BP Energy Outlook. Accessed July 2019:

https://www.bp.com/content/dam/bp/business-sites/en/global/corporate/pdfs/energyeconomics/energy-outlook/bp-energy-outlook-2019.pdf

Bustos-Salvagno, J. 2019. "Chilean experience on long-term electricity auctions: Changes and challenges ahead," IAEE Energy Forum.

Available: https://www.iaee.org/en/publications/newsletterdl.aspx?id=816

Chilean Ministry of Environment (MMA). 2018. "Gobierno y generadoras anuncian fin de nuevos desarrollos de plantas a carbon.” Accessed March 2019: https://mma.gob.cl/gobierno-ygeneradoras-anuncian-fin-de-nuevos-desarrollos-de-plantas-a-carbon/

Chilean Ministry of Energy and GIZ. 2014. "Energías renovables en Chile: El potencial eólico, Solar e hidroeléctrico de Arica a Chiloé.” Accessed July 2019: http://4echile.cl/4echile/wpcontent/uploads/2017/03/Energias-Renovables-en-Chile-El-potencial-eolico-solar-ehidroele $\%$ CC $\% 81$ ctrico-de-Arica-a-Chiloe.pdf

Chilean National Electricity Coordinator. 2019. "Estudio de Operación y Desarrollo del SEN sin centrales a carbón - Informe Principal.” Accessed May 2019: https://www.coordinador.cl/wpcontent/old-docs/2019/01/20190102-Estudio_OPyDES-Sin-carb\%C3\%B3n_Informe Principal.pdf

Comisión Nacional de Energía (CNE). 2019a. "Information and Statistics." Accessed March 2019: https://www.cne.cl/en/estadisticas/electricidad/

Comisión Nacional de Energía CNE. 2019b. “Consumo Mensual GN.” Accessed May 2019: https://www.cne.cl/estadisticas/ hidrocarburo/

Comisión Nacional de Energía CNE. 2019c. "Hydrocarbon.” Accessed May 2019: https://www.cne.cl/estadisticas/ hidrocarburo/

Electricidad. 2019. "Comisión asesorará al Ministerio de Energía para definir ruta de flexibilidad en sector eléctrico.” Accessed August 2019: http://www.revistaei.cl/2019/08/05/comisionasesorara-al-ministerio-de-energia-para-definir-ruta-de-flexibilidad-en-sector-electrico/\#

EPE. 2018. "International LNG Market: Impacts on Brazil.” Accessed November 2018: http://www.epe.gov.br/sites-en/publicacoes-dados-abertos/publicacoes/Publicacoes Arquivos/publicacao-183/LNG\%20International\%20Market\%20Report\%202018-2027_rev1.pdf

Generadoras de Chile. 2017. "Long-term analysis of the Chilean national electricity system considering variable and intermittent energy resources." Accessed March 2019: http://generadoras.cl/media/page-files/237/Terms\%20of\%20Reference $\% 20 \mathrm{AG} \% 202017$ _01\%20-\%20English $\% 20$ Version $\% 20 \mathrm{v} \% 2013022017 . \mathrm{pdf}$

Helioscsp. 2019. "Cerro Dominador Concentrated Solar Power developer plans larger plants in Chile.” 16 October. http://helioscsp.com/cerro-dominador-concentrated-solar-power-developerplans-larger-plants-in-chile/ 
Houllier, M. A. and de Menezes, L. M. 2012. "A fractional cointegration analysis of European electricity spot prices," in Proc. 9th International Conference on the European Energy Market, pp. 1-6.International Energy Agency (IEA) (2018a), Electricity Information 2018. Accessed January 2019: https://webstore.iea.org/electricity-information-2018

International Energy Agency (IEA). 2018. "Energy policies beyond IEA countries: Chile 2018 review." Accessed August 2019: https://webstore.iea.org/energy-policies-beyond-iea-countrieschile-2018-review

Maluenda, B. and Moreno, J. 2018. "New market interactions in the Chilean electricity system with high integration of variable renewable energy," in Proc. $41^{\text {st }}$. IAEE International Conference, pp. 1-15.

Manríquez, E. F. I. 2018. "Demand response and renewable energy integration in the Chilean electricity market." Accessed July 2019:

http://repositorio.uchile.cl/bitstream/handle/2250/167802/Demand-response-and-renewableenergy-integration-in-the-chilean-electricity-market.pdf? sequence $=1 \&$ isAllowed $=y$

Mastropietro, P.; Batlle, C.; et al. 2016. "The evolution of electricity auctions in South America," Energy Sources, Part B: Economics, Planning, and Policy, vol. 11, no. 12, pp. 1103-1110, 2016.

Morales, O.; Mocarquer, S.; et al. 2015. "Benefits of industrial demand response in the Chilean electricity market," IEEE Power and Energy Society General Meeting. Available:

http://www.systep.cl/documents/Morales_PES_GM_2015.pdf

Moreno, R., Ferreira, R., Barroso, L., Rudnick, H., and Pereira, E., 2017. "Facilitating the integration of renewables in Latin America: The role of hydropower generation and other energy storage technologies," IEEE Power and Energy Magazine, vol. 15, no. 5, pp. 68-80, Sept.-Oct.

Pollitt, M. 2004. "Electricity reform in Chile: Lessons for developing countries," Journal of Network Industries, vol. 5, no. 3-4, pp. 221-262.

PSR and Moray. 2018. "Flexibility costs under high variable renewable energy generation: The Chilean case." Accessed April 2019: http://www.morayenergy.com/archivos/pdf/moray-energypresentation-at-ieee-power--energy-society-general-meeting-pdf-1.pdf

Rebolledo, A. 2018. "Chile and the solar revolution," in Global Innovation Index 2018: Energizing the World with Innovation. Available: https:/www.wipo.int/edocs/pubdocs/ en/wipo_pub_gii_2018.pdf

Rypl, N. C. 2018. "Chile's new coal fleet challenged by renewables and air pollution,” Powering Past Coal Alliance (PPCA). Available: https://poweringpastcoal.org/insights/policy-andregulation/chile-new-coal-fleet-challenged-by-renewables-and-air-pollution

Systep. 2019. “Estadisticas.” Accessed August 2019: http://www.systep.cl/?page id=1203 
Valdes, J.; González, A. B. P.; et al. 2019. "Industry, flexibility, and demand response: Applying German energy transition lessons in Chile," Energy Research \& Social Science, vol. 54, pp. 1225.

World Resources Institute (WRI). 2015. "Ranking the world's most water-stressed countries in 2040.” Accessed August 2019: https:/www.wri.org/blog/2015/08/ranking-world-s-most-waterstressed-countries-2040 


\section{Colombia}

\subsection{Electricity Sector Outlook}

Electricity consumption in Colombia has grown 3\% per year in average since 2010. The Colombian government estimates that electricity demand in the country will continue to grow at the same average rate until the year 2030. Colombia's electricity system is stressed during droughts because $70 \%$ of its installed capacity comes from hydropower and its water storage capability is limited. The government aims at diversifying the generation fleet by increasing natural gas, wind, and solar generation (Rudnick and Velásquez 2019; International Renewable Energy Agency 2018).

\subsubsection{Sector Reform}

Colombia has historically relied on hydropower to supply domestic consumption. Increasingly, this has presented a challenge as electricity consumption grows and severe droughts caused by El Niño cripple domestic electricity production.

Different from the other South American countries studied in this report, Colombia developed a competitive (bid-based) wholesale electricity market, which was established between 1994 and 1995 in response to the country's poor electric reliability and, in particular, Colombia's energy crisis of 1992. This crisis resulted in a large blackout and a long period of electricity rationing (Organisation for Economic Co-operation and Development 2015).

The reform required unbundling vertically integrated utilities and allowing competition in generation and retail ${ }^{10}$, while maintaining regulated monopolistic activity in transmission and distribution. Colombian regulations require open access to the transmission and distribution grids. Colombian regulations define the participants allowed in the wholesale energy market: electricity generators, distribution network operators, retail suppliers, non-regulated customers (large consumers with monthly peak demand of more than $100 \mathrm{~kW}$ ) (Nieves Zárate and Hernández Vidal 2016; Rudnick and Velásquez 2019).

\subsubsection{Wholesale Electricity Market}

The Colombian wholesale electricity market has three main components: 1) bilateral energy contracts, 2) a day-ahead energy spot market, and 3) a firm energy procurement that functions as a capacity market based on auctions (Table 8).

Table 8. Transaction Types Allowed in the Wholesale Energy Market in Colombia

\begin{tabular}{|lll|}
\hline Type of Transaction & Term & Purpose \\
\hline Bilateral Contracts & $\begin{array}{l}\text { Set by the } \\
\text { parties }\end{array}$ & $\begin{array}{l}\text { Market-based mechanism for large customers to secure } \\
\text { energy and hedge against spot market spikes }\end{array}$ \\
\hline Spot Market & Day-ahead & Secure energy to meet system demand in the short term \\
\hline $\begin{array}{l}\text { Firm Energy } \\
\text { Procurement }\end{array}$ & 20 years & Ensure supply during periods of hydropower deficits \\
\hline
\end{tabular}

\footnotetext{
${ }^{10}$ Retailers can sell electricity to large and small customers.
} 
Large consumers (those with a monthly peak demand of $100 \mathrm{~kW}$ or more), retailers, and distributors are allowed to participate in the day-ahead spot market; whereas registered generators are mandated to participate. The bid of the most expensive plant required to meet demand determines the spot market-clearing price (Giraldo and Robinson 2016).

The firm energy procurement mechanism provides market-based incentives for generators to supply electricity during periods of scarcity. Established in 2007 to address the shortages caused by the country's heavy reliance on hydropower and recurrent droughts, Colombia's firm energy procurement mechanism is analogous to and served as a model for capacity markets in North America and Europe (McRae and Wolak 2019).

The Colombian Ministry of Mines and Energy is responsible for establishing Colombia's domestic energy policy and coordinating its execution. Colombia's Mining and Energy Planning Unit (UPME) is responsible for planning and overseeing the development and exploitation of the country's energy resources (Bnamericas 2019b). The Colombian wholesale electricity market is administered and operated by XM, a public utility corporation (equivalent to an independent system operator (ISO) in the United States) and a subsidiary of the state transmission Interconexiones Eléctricas S.A. (ISA) (XM 2019a; U.S. EIA 2019). The Electricity and Gas Regulatory Commission (CREG) is a public utilities commission that functions at the federal level to regulate the provision of electricity and natural gas in Colombia.

\subsubsection{Electricity Subsidization}

Colombia has a system of energy subsidization designed to help people afford their utility bills according to geographical and socioeconomic criteria. Households receive a subsidy level according to a system of six tiers that correlate to annual income. The first-tier groups households with the lowest income and receives a subsidy of $50 \%$ as long as they do not exceed a threshold of $173 \mathrm{kWh}$ per month. ${ }^{11}$ Tier 2 receives $40 \%$ and Tier $3,15 \%$, with the same consumption threshold. Tier 4 does not receive any subsidies and tiers 5 and 6 pay an extra contribution of $20 \%$, which is meant to offset the subsidies provided to tiers 1, 2 and 3 (Ministerio de Minas y Energía 2018).

Figure 54 shows the evolution of electricity subsidies in Colombia from 2012 to 2018 (with 2018 values estimated). The government is considering lowering subsidies to public utilities ${ }^{12}$ because their total net cost was more than $\$ 734$ million in 2018 - of which electricity subsidies contributed approximately $\$ 481$ million. Furthermore, the government has found that many households are currently miscategorized. The government estimates that up to $61 \%$ of the households classified in the lowest three strata would not qualify as low-income because strata are defined geographically and not based on actual household income. Similarly, some lowincome households are classified in the higher tiers (Cigüenza Riaño 2019).

\footnotetext{
${ }^{11}$ The consumption threshold is $130 \mathrm{kWh}$ per month for households in cities with an altitude of more than 1,000 meters $(3,281$ feet) above sea level.

12 The Colombian government subsidies electricity, gas, water and sewer services.
} 


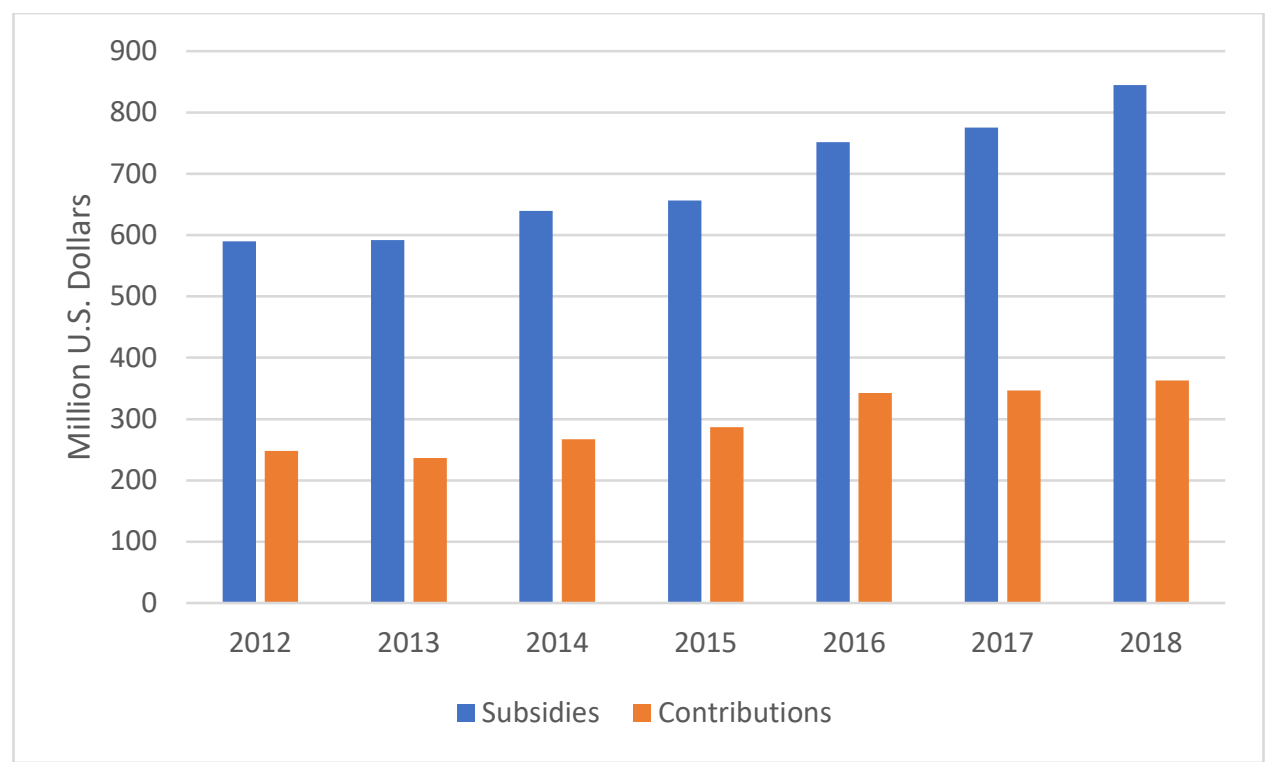

Source: Data from Unidad de Planeación Minero Energética $(2013 ; 2018)$

Figure 54. Subsidies and contributions paid to and by electricity customers in Colombia 2012-2018

\subsubsection{Renewable Energy Law}

Colombia enacted in 2014 the Renewable Energy Law to regulate non-hydropower renewable sources of power. The country does not have legally-binding solar and wind renewable energy (which the country refers to as non-conventional) deployment goals, but it has the aspiration to increase their capacity to $9 \%$ - approximately 1,500 MW - by 2023 (Symmes Cobb 2019a). Other sources indicated even higher deployment targets (Renewables Now, 2019). Projections from the government planning agency estimate that by $2030,17 \%$ of the country's total capacity could come from solar and wind plants, with an additional 3\% from biomass plants (International Renewable Energy Agency 2018).

\subsubsection{Consumption}

In 2017, electric consumption in Colombia was 67 TWh. Approximately $69 \%$ of demand came from small consumers, which regulation defines as consumers with a monthly peak demand under $100 \mathrm{~kW}$ and includes residential customers and small business (see Figure 55). Small consumers are called regulated consumers and cannot participate in the wholesale electricity market. Industrial manufacturing accounted for $14 \%$ of demand, mining for $7 \%$, and other large commercial and industrial customers $11 \%$. Colombia exports less than $1 \%$ of its generation to Ecuador and Venezuela (XM 2018). 


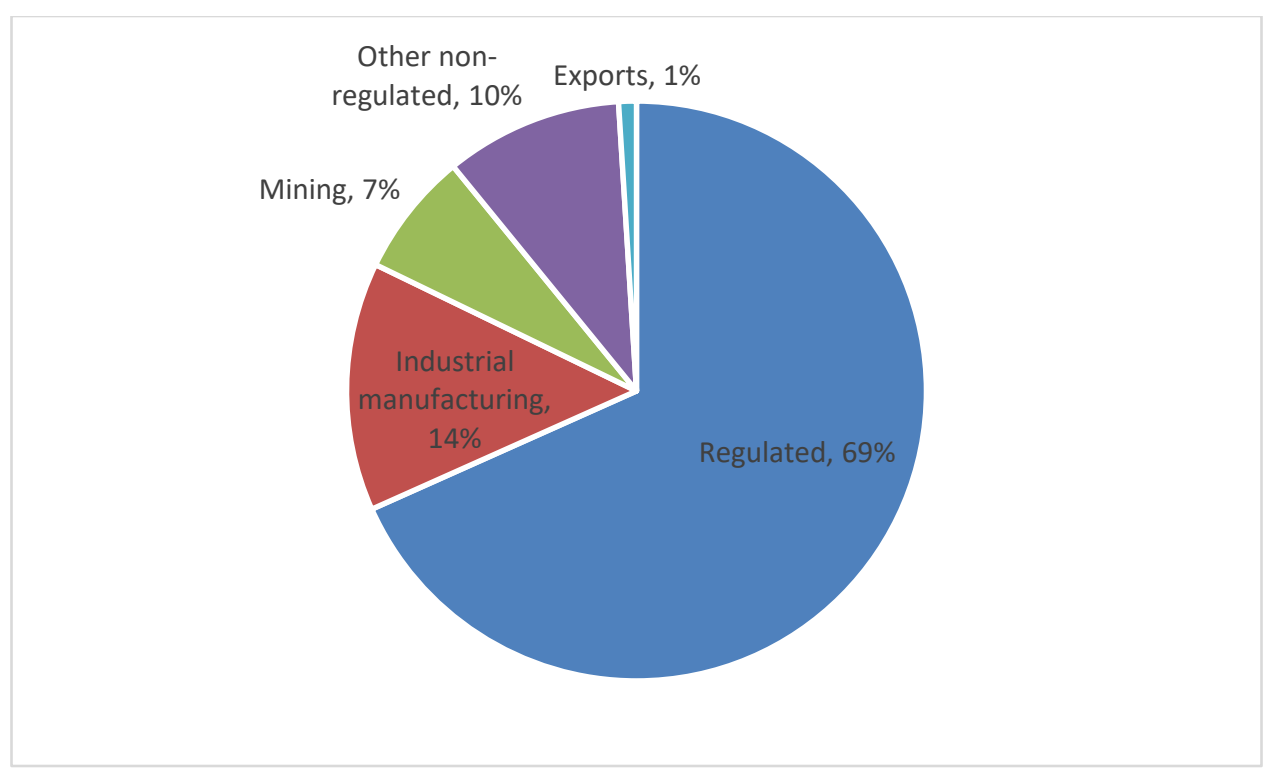

Source: Data from Unidad de Planeación Minero Energética (2019)

Figure 55. Electricity consumption by sector in 2017

Domestic demand for electricity in Colombia is projected to grow at an annual rate of 3\% between 2015 and 2029 (the most recent comprehensive expansion planning report was published in 2014). Figure 56 shows the estimated demand growth by region. Regions with the highest urbanization and population density, namely West, Central and Coast-Caribbean, will see the highest growth rate, above the national average of $3 \%$. The "Other" category comprises the largest consumers of electricity in the country, such as Ecopetrol and Drummond Ltd., one of Colombia's largest mine operators (Unidad de Planeación Minero Energética 2014).

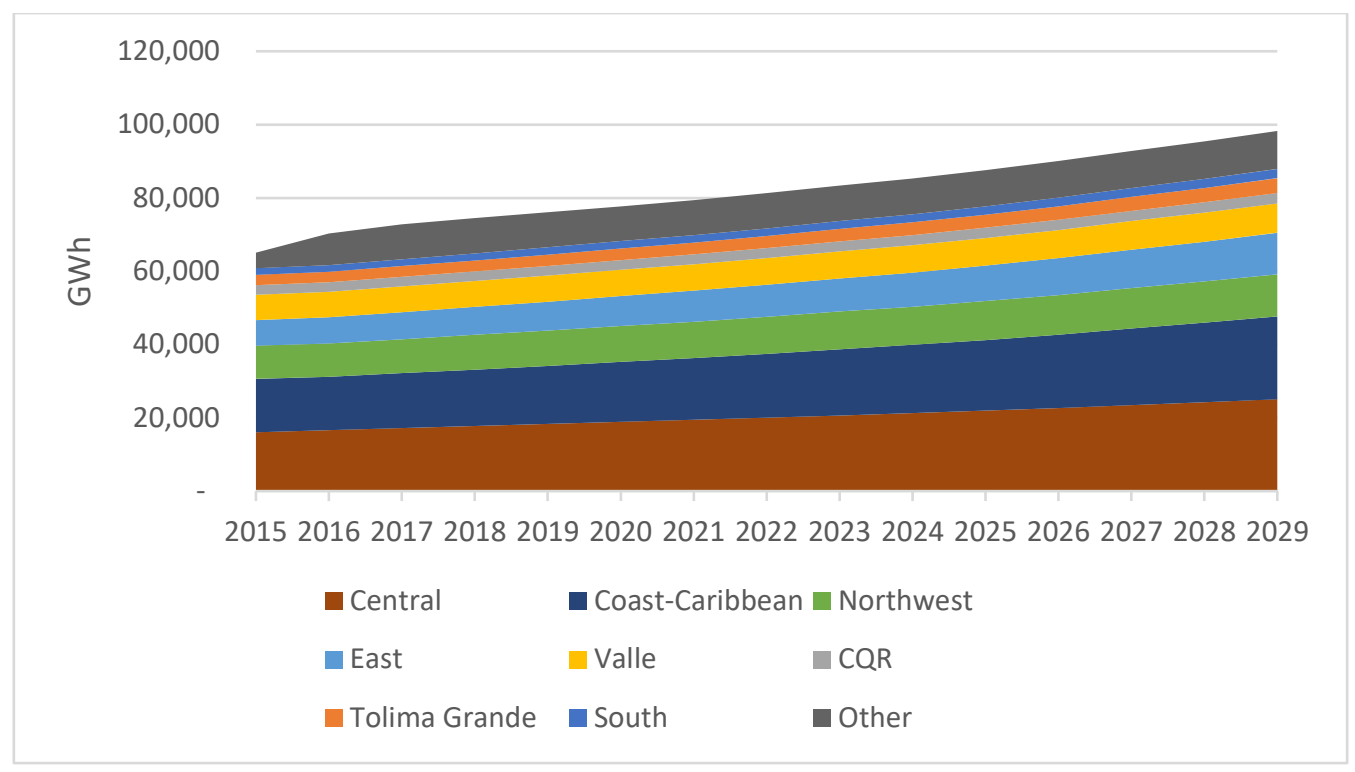

Source: Data from Unidad de Planeación Minero Energética (2014)

Figure 56. Colombia's domestic electricity demand projection, 2018-2029 


\subsubsection{Generation}

\subsubsection{Hydropower and Thermal Generation}

By August 2018, 69\% of the country's installed capacity was hydropower. Coal and natural gas plants represented $10 \%$ of total generation capacity each. The rest is a combination of different types of oil products and less than one percent is "other" renewable energy, including $0.8 \%$ biomass (Unidad de Planeación Minero Energética 2018). Colombia is the largest coal producer in South America, but 90\% of its production is exported (BP 2019).

Like many other countries in the region, Colombia has historically relied heavily on hydropower to meet its domestic demand for electricity. In 2017, Colombia had an installed capacity of about $12 \mathrm{GW}$, the third largest in South America. However, annual hydropower generation varies significantly depending on the strength of the El Niño weather phenomenon. Hydropower generation increased from $67.1 \%$ of total generation in 2016, which marked the end of the longest El Niño event since 1950, to 80.3\% in 2017 (XM 2018; International Hydropower Association 2018). Such variations are also caused by the country's limited water storage capacity (Rudnick and Velásquez 2019).

Figure 57 shows the total and regional installed capacity to generate electricity in Colombia in 2012 and 2019. The share of hydropower capacity in Colombia has remained at a high level despite the government efforts to diversify the country's electricity matrix since the inception of the wholesale energy market. A big part of the push to liberalize the market was to incentivize the development of alternative forms of electricity, but hydropower capacity has remained steady, while natural gas has fallen. In the generation mix, gas generation is also shrinking, while hydropower output has been up strongly in recent years (Figure 58).

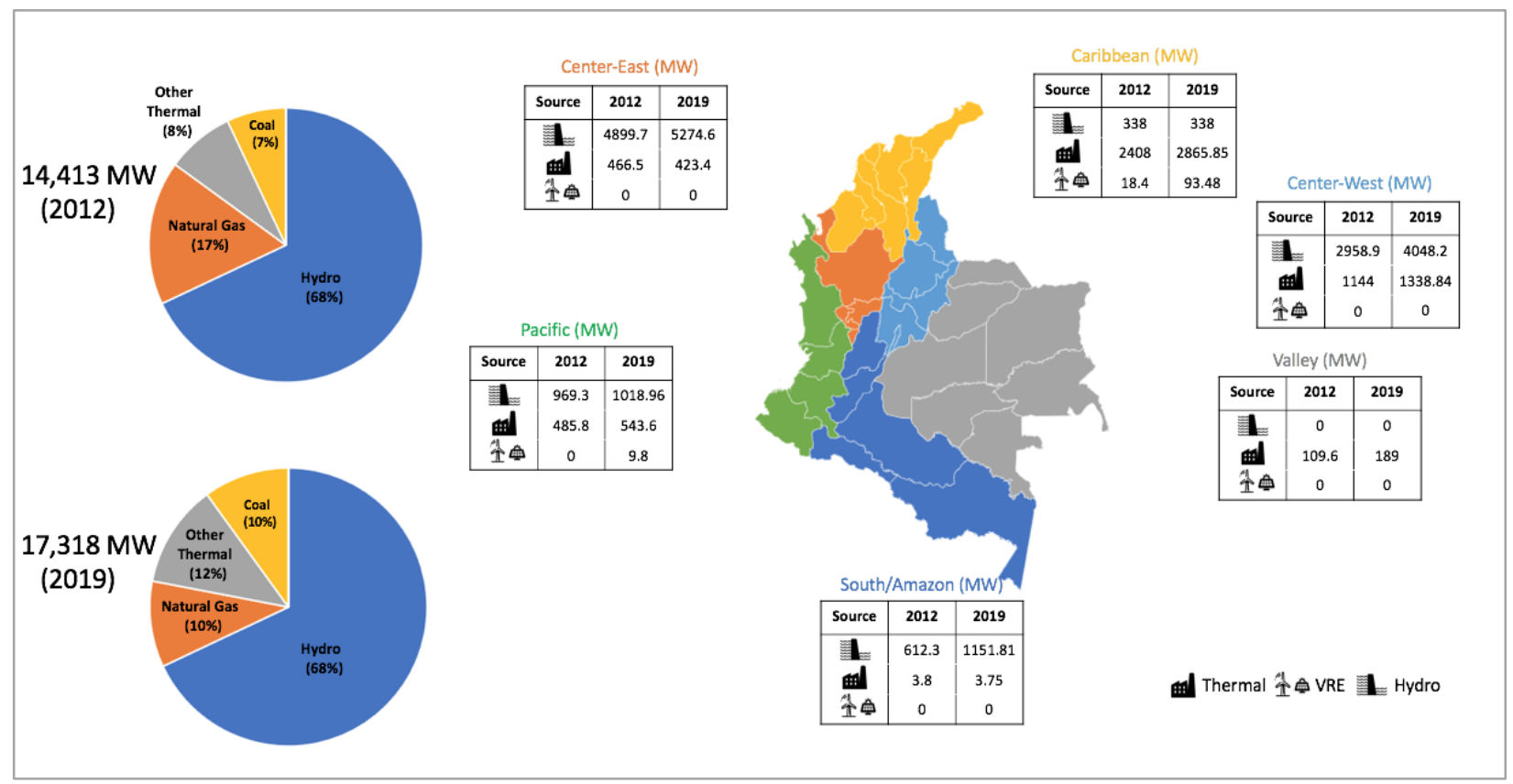

Source: SIEL (2019), UPME (2017), DNP (2017)

Figure 57. Total and regional installed capacity for Colombia, 2012 and 2019 


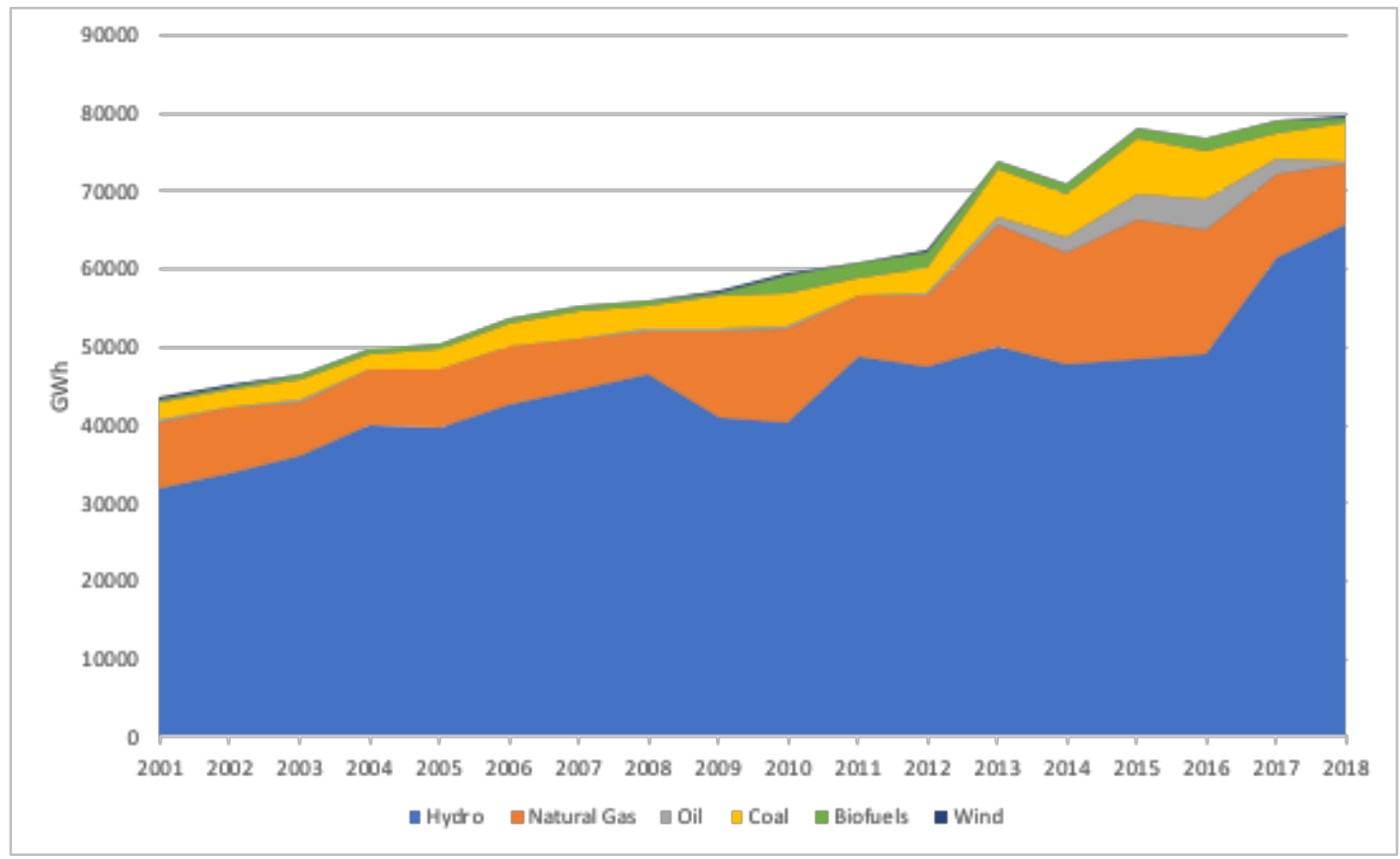

Source: IEA (2019), XM (2019b)

Figure 58. Colombia's evolving generation mix, 2001-2018.

Note: IEA data is through 2017 with an extrapolation for 2018 based on generation percentages from XM.

\subsubsection{Other Renewable Energy Sources}

Generation capacity from non-hydropower renewable forms of generation is negligible. Biomass capacity represents $0.8 \%$ of total capacity, wind $0.1 \%$ and solar $0.06 \%$. Since at least 2018 , the Colombian government has tried to hold auctions to attract renewable energy investment, but such attempts had been delayed for various reasons until February 2019, when the first auction took place. The results had to be discarded, however, because not enough buyers participated, which triggered rules to avoid market power concentration (Bnamericas 2019a). On 22 October 2019 , a second attempt was made to auction new wind and solar projects after incorporating lessons learned from earlier in the year and this time buyers and sellers met all requirements. A reported $1298 \mathrm{MW}$ of long-term wind and solar off-take contracts were announced (Renewables Now 2019). Some of the changes between the two auctions include: exclusion of fossil and hydro resources, reduction of minimum project size from $10 \mathrm{MW}$ to $5 \mathrm{MW}$, allocation of hourly $0.5 \mathrm{MWh}$ blocks on a daily basis, inclusion of "take or pay" with guaranteed delivery from seller, inclusion of 15 year contract durations, and movement of the auction to an online platform (Stout 2019).

\subsubsection{Transmission Infrastructure}

Colombia's national transmission system has 16,000 miles of transmission lines, owned and operated by transmission utilities. Transmission utilities operate as regulated monopolies, each in their respective territory. Transmission utilities can participate in government auctions for new projects. ISA is owned by the government and is the biggest of the four transmission utilities in Colombia. ISA owns $70 \%$ of Colombia's national transmission system. The other transmission utilities are EEB, TRANSELCA and DISTASA (DISTASA 2019; Interconexión Eléctrica S.A. E.S.P ISA 2019). ISA is also a system and market operator through XM, its subsidiary. 
Colombia's transmission system is connected to Ecuador and Venezuela. Interconnection lines to Ecuador provide $395 \mathrm{MW}$ of import capacity and $535 \mathrm{MW}$ export capacity. Interconnection lines to Venezuela provide $205 \mathrm{MW}$ of import capacity and $336 \mathrm{MW}$ export capacity (Rudnick and Velásquez 2019).

Figure 59 shows the transmission lines in Colombia, including the lines that provide import/export capacity to Venezuela and Ecuador. The largely rural south east area of the country is not covered by transmission lines.

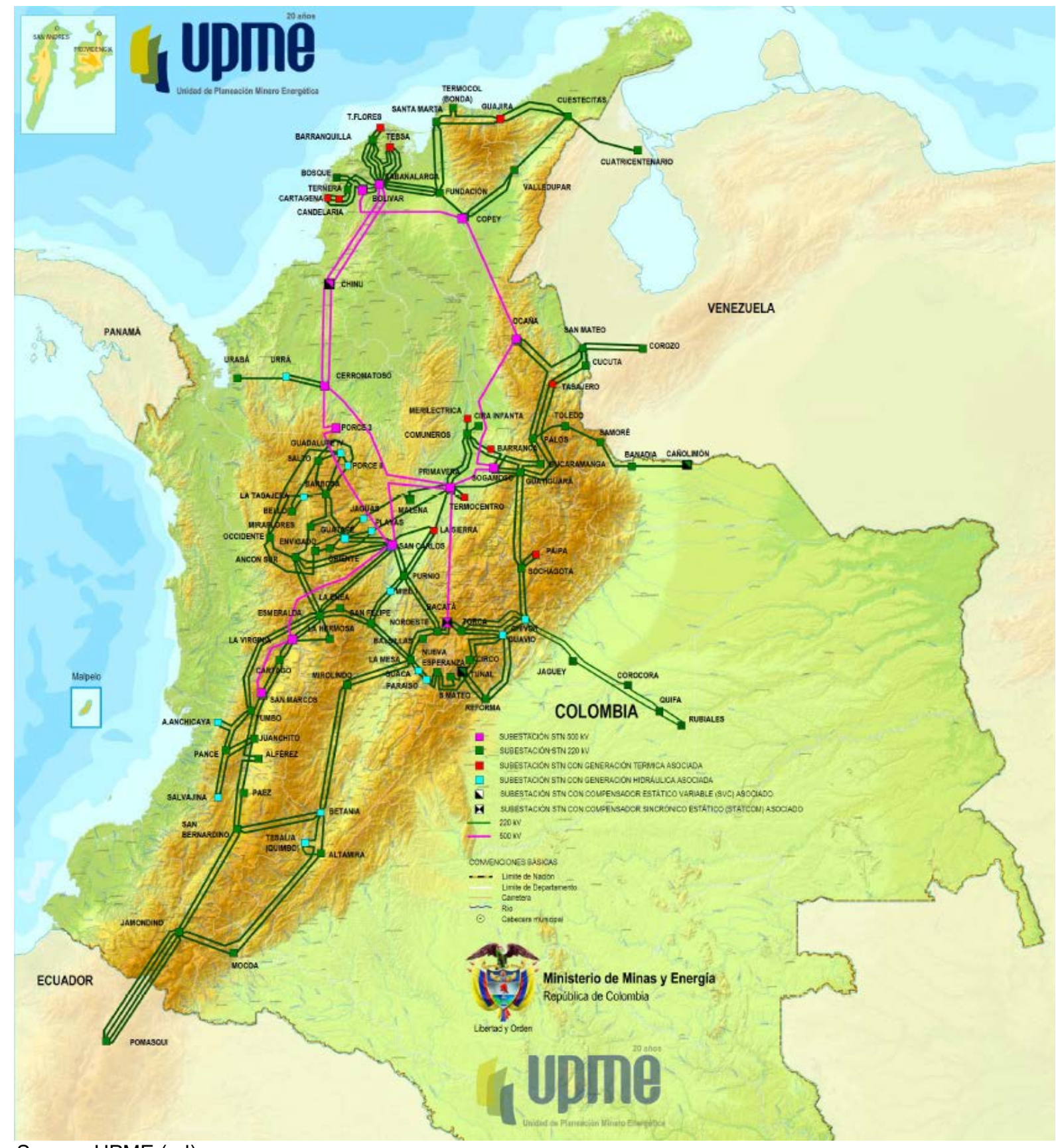

Source: UPME (nd)

Figure 59. Colombia's transmission lines 


\subsection{Natural Gas Overview}

Colombia's oil and gas sectors are in transformation. Production from domestic oil and gas fields is declining, while the country's primary energy demand has grown at an average rate of $4 \%$ annually since 2007. In 2018, Colombia's natural gas imports exceeded exports for the first time since 1998, and the country had its largest gas deficit since 1977. Natural gas production from the fields in the Guajira Department, the most productive area in Colombia, has fallen to half of its 2010 peak. Colombia imported LNG for the first time in 2016. The Ministry of Mines and Energy estimates 5.7 and 11 years of current oil and gas reserves at current production levels, respectively (Symmes Cobb and Acosta 2019; BP 2019).

\subsubsection{Sector Organization}

Colombia's natural gas sector did not develop significantly until the 1970s, when the Guajira field was discovered. In the 1980s, the government instituted policies to stimulate the domestic consumption of natural gas, and in the 1990s, the pipeline system was expanded by more than 1,000 miles in order to interconnect existing fields with larger cities around the country. In 1997, Ecopetrol, the government's oil and gas company, was divided in two: oil extraction activities remained under Ecopetrol, while gas production and transportation activities were housed under a new company, Ecogas (Comisión de Regulación de Energía y Gas 2013b).

Colombia's Energy and Gas Regulatory Commission (CREG) is responsible for regulating and protecting the rights of sector participants. CREG's mandate is to ensure consumers receive utility services in a safe and cost-efficient way. Colombia has a liberalized natural gas market with a structure similar to the electricity market (Comisión de Regulación de Energía y Gas 2013a). The supply and commercialization chain is divided in four segments: production, transportation, distributers and retailers, and pure retailers. Up to 48 companies participate in each segment (Comisión de Regulación de Energía y Gas, 2019).

\subsubsection{Consumption}

Approximately half of Colombia's natural gas production is reinjected. Figure 60 shows the sectors that consume the most natural gas in Colombia, excluding the reinjected gas. Thermal production of electricity and the industrial sectors consume most of the production available after reinjection and internal consumption by the natural gas sector. Colombia has a significant number of natural gas vehicles; therefore, the transportation sector is an important consumer of natural gas (U.S. EIA 2019; Rudnick and Velásquez 2019; Unidad de Planeación Minero Energética 2018, 2014). 


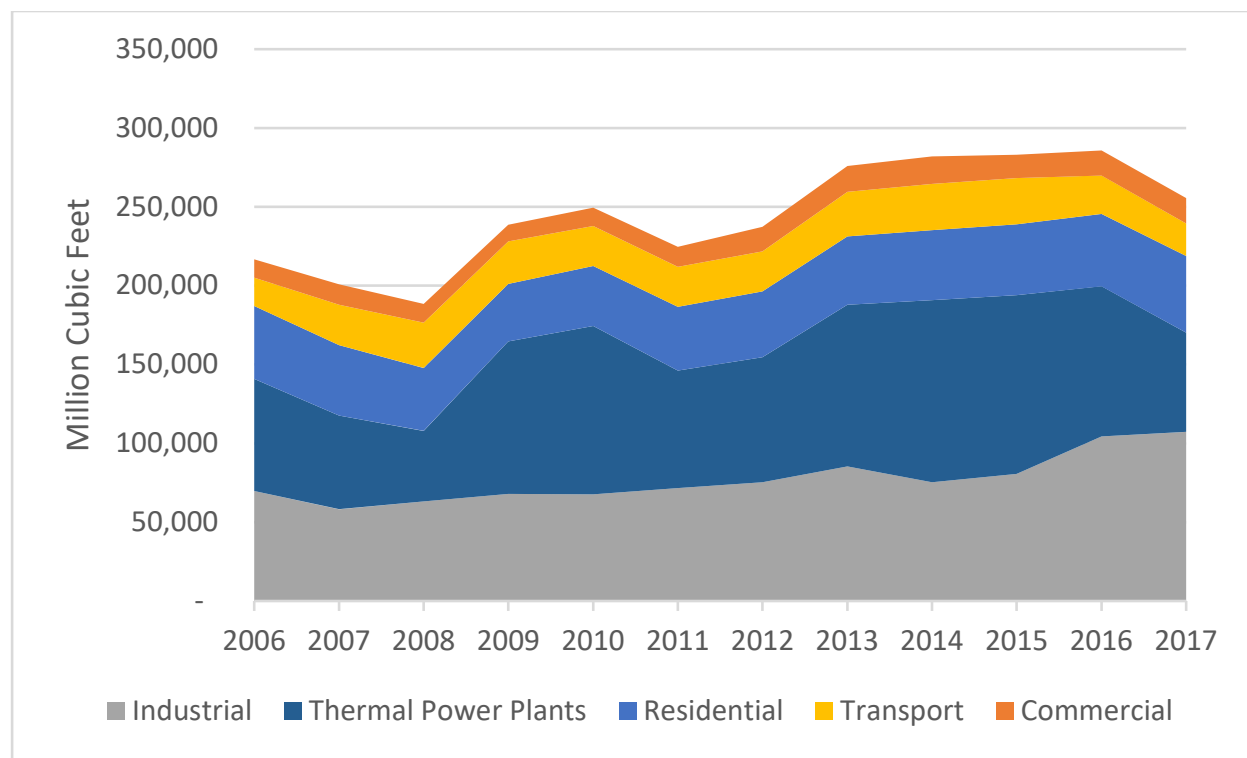

Source: Data from Unidad de Planeación Minero Energética (2018b)

Figure 60. Main sectors for the final consumption of natural gas in Colombia

\subsubsection{Domestic production}

Colombia's natural gas production has been declining for the last decade. Currently, the government estimates 11 years of reserves in existing fields. Shale oil and gas extraction could nearly triple Colombia's reserves, extending oil and gas reserves to 15 and 30 years of reserves, respectively. Hydraulic fracturing projects had been on hold since 2018, when Colombia's High Court ruled there needed to be absolute certainty no environmental damage would result from the projects. The country's top administrative court, the Council of State, is hearing a case on whether hydraulic fracturing should be allowed but has given permission to four pilot projects to go ahead (Newbery 2019; Symmes Cobb 2019b). Most of the untapped natural gas reservoirs of significant size are off the Colombian coast in the Caribbean Sea (Symmes Cobb and Acosta 2019; Natural Gas News 2019). Production has been declining since its peak in 2009. Colombia started importing natural gas in 2016 (Table 9). 
Table 9. Colombian Production and Imports by Year, 2006-2017

(million cubic feet)

\begin{tabular}{|rrr|}
\hline Year & Production & Imports \\
\hline 2006 & $1,378,352$ & 0 \\
\hline 2007 & $1,223,973$ & 0 \\
\hline 2008 & $1,382,617$ & 0 \\
\hline 2009 & $1,919,376$ & 0 \\
\hline 2010 & $1,143,015$ & 0 \\
\hline 2011 & $1,102,311$ & 0 \\
\hline 2012 & $1,086,464$ & 0 \\
\hline 2013 & $1,043,847$ & 0 \\
\hline 2014 & 957,387 & 0 \\
\hline 2015 & 899,597 & 0 \\
\hline 2016 & 904,145 & 500 \\
\hline 2017 & 856,362 & 501 \\
\hline
\end{tabular}

Source: Data from Unidad de Planeación Minero Energética (2018b)

The government aims to increase electricity production from natural gas plants to improve electric reliability and to reduce the country's dependence on hydropower.

In 2017, two private companies made the biggest natural gas discovery in nearly three decades in Colombia. More discoveries in the Caribbean provide encouraging results. However, it is estimated that it will take approximately ten years for the production from the new fields to reach commercialization (Ramirez 2018).

\subsubsection{Imports}

\subsubsection{Pipeline Imports}

Colombia and Venezuela share a gas pipeline, but due to the fact that Venezuela re-injects most of its produced natural gas to maintain reservoir pressure, the government is not currently looking to import gas from Venezuela.

\subsubsection{LNG Imports}

Liquefied natural gas has emerged recently as another near-term solution to the growing consumption of gas in the country.

Colombia started importing LNG in 2017 through its first FSRU (commissioned in 2016), located at the Atlantic port of Cartagena. The national mining and energy planning unit (UPME) has proposed a second terminal on Colombia's Pacific coast. This project would also require the construction of a pipeline from the coast to the city of Cali (U.S. EIA 2019; Sbroiavacca et al. 2019). 
In 2018, Colombia received 59\% of its total LNG imports from Trinidad and Tobago and the rest from the United States (International Gas Union 2019). The government estimates that LNG imports will double from 2018 to 2019. The effects of El Niño in 2019 are driving the increased demand for natural gas (Portafolio 2019).

Given the financial investment and lead time needed to start commercial production from the recent gas deposit discoveries, Colombia may need a third FSRU within a decade (Bnamericas 2018).

\subsubsection{Natural Gas Transportation Infrastructure}

Colombia has nine pipelines with a total length of 3,781 km (2,360 mi). Figure 61 shows Colombia's natural gas transportation network. The country has seven natural gas transportation companies from which Promigas and TGI are the two most important.

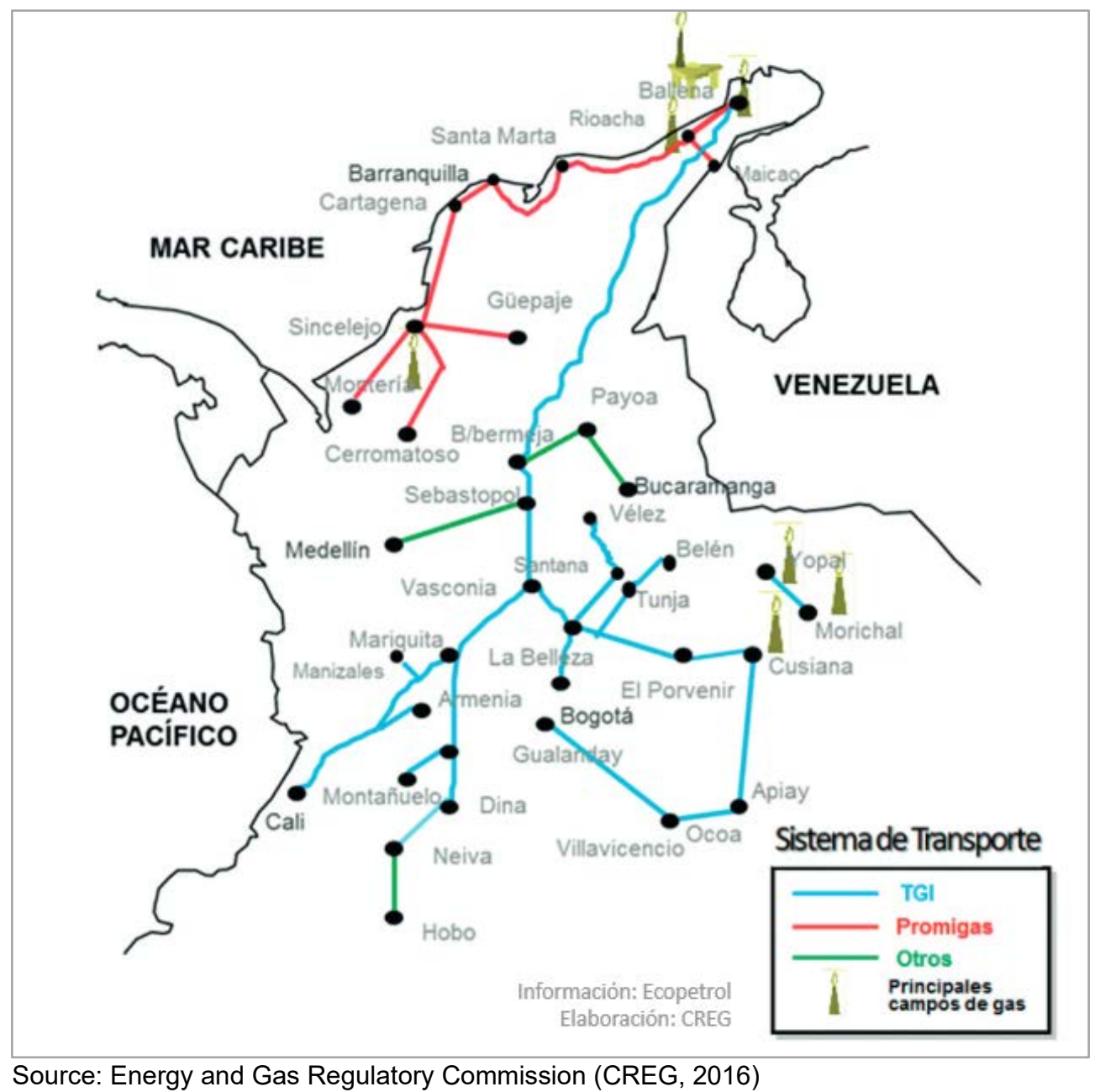

Figure 61. Colombia's natural gas pipelines and offshore licenses 


\subsection{Power System Flexibility}

\subsubsection{Sources of Flexibility}

\subsubsection{Thermal Power Plants}

Approximately $30 \%$ of Colombia's power capacity comes from thermal plants. The Colombian government has tried to increase the share of thermal generation in the electricity matrix to prevent stresses on the electrical system during the country's dry season or during severe droughts. The main mechanism to incentivize stable generation is the country's reliability market in which providers of dispatchable electricity are compensated for reducing the volatility in energy prices generated by hydropower output variability (see Figure 63). The reliability market was implemented in 1996. However, the reliability market has not been effective in increasing the share of thermal generation since its inception (Rudnick and Velásquez 2019). Critics of the Colombian reliability market point out that this mechanism encourages generators to withhold output to create scarcity conditions and increase their profits (McRae and Wolak 2019). Additionally, the reliability market discourages investment in solar and wind power because the reliability market is not designed to incentivize variable sources of electricity (Giraldo and Robinson 2016).

\subsubsection{Imports}

Colombia has transmission infrastructure that enables energy exchanges with Venezuela and Ecuador. Electricity imports and exports have not historically been more than a fraction of one percent. However, Ecuador is planning to build extra hydropower and thermoelectric capacity to supply energy to Colombia when the Colombian system is stressed (Argus Media 2018).

\subsubsection{Drivers of the Need for Flexibility}

\subsubsection{Rainfall variability}

Colombia is vulnerable in different ways to the recurrent weather phenomena known as El Niño and La Niña. In the years when El Niño occurs, Colombia experiences a higher risk of droughts and forest fires. Although El Niño is not caused by human activity, there is evidence that climate change may exacerbate the intensity and impacts of El Niño (Harindranath 2018). Given the country's reliance on hydropower, occurrences of El Niño severely reduce the ability of the electricity system to meet demand. Droughts caused by El Niño, deficient electricity supply planning and the failure of important generators during vulnerable periods have contributed to water rationing, as well as brownouts and blackouts in Colombia since the 1990s (Semana 2007; Clavijo, Vera, and Cuéllar 2016).

Due to its reliance on hydropower and limited water storage capacity, electricity production in Colombia is especially vulnerable to droughts; $6 \%$ of total capacity in reservoirs can store water for more than six months (Giraldo and Robinson 2016). The wholesale energy market is frequently subject to extreme variation in the net capacity available in the system, which causes spikes in spot prices. El Niño events can reduce hydropower capacity by $20 \%$ during periods of five to twelve months (XM 2019a).

Figure 62 shows the relationship between monthly average impoundment levels as a percentage of their nominal total volume and the strength of the El Niño phenomenon between January 2012 
and June 2018. The largest determinant of impoundment levels is seasonal precipitation. The period that roughly correlates with the Boreal summer is the dry season in Colombia. Nearly every year, the lowest water levels in impoundments are correlated with the end of the dry season, usually sometime between February and April. December, the start of the dry season, correlates with highest water levels in impoundments. A very strong El Niño event occurred in the 2015-2016 season. At the end of this period of unusual El Niño intensity, average impoundment levels dropped below 40\% of total volume (Golden Gate Weather Services 2019; XM 2019a).

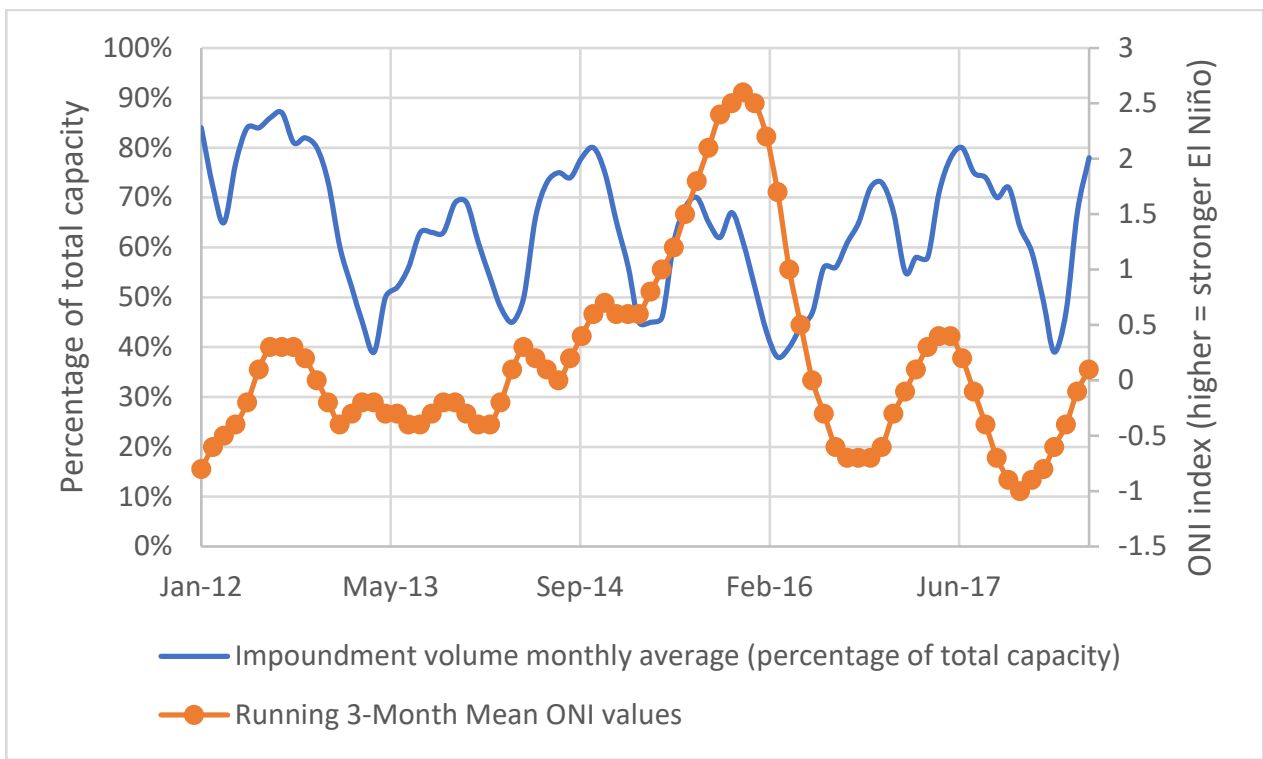

Source: Data from XM (2019a)

Figure 62. Impoundment volume monthly average as a percentage of total volume capacity

Figure 63 shows the inverse relation between spot price volatility and hydropower generation. The figure shows important decreases in hydropower generation in February and March 2017. During that period, the spot market experienced spikes in prices. The average spot price in 2017 was $107.77 \mathrm{COP} / \mathrm{kWh}, 65 \%$ lower than the $305.19 \mathrm{COP} / \mathrm{kWh}$ of 2016 , a year of a strong El Niño event $^{13}$ (XM 2018). Hydropower creates such volatility because it is a low-cost form of electricity when it is available, which depresses the market clearing price. But when hydropower availability drops, it creates scarcity due to the dependence of the system on hydropower output.

${ }^{13}$ In 2017, the average exchange rate between the Colombian peso (COP) and the U.S. dollar was just below 3000 to 1. https://www.X-rates.com/average/?from $=\mathrm{USD} \&$ to $=\mathrm{COP} \&$ amount $=1 \& y e a r=2017$ 


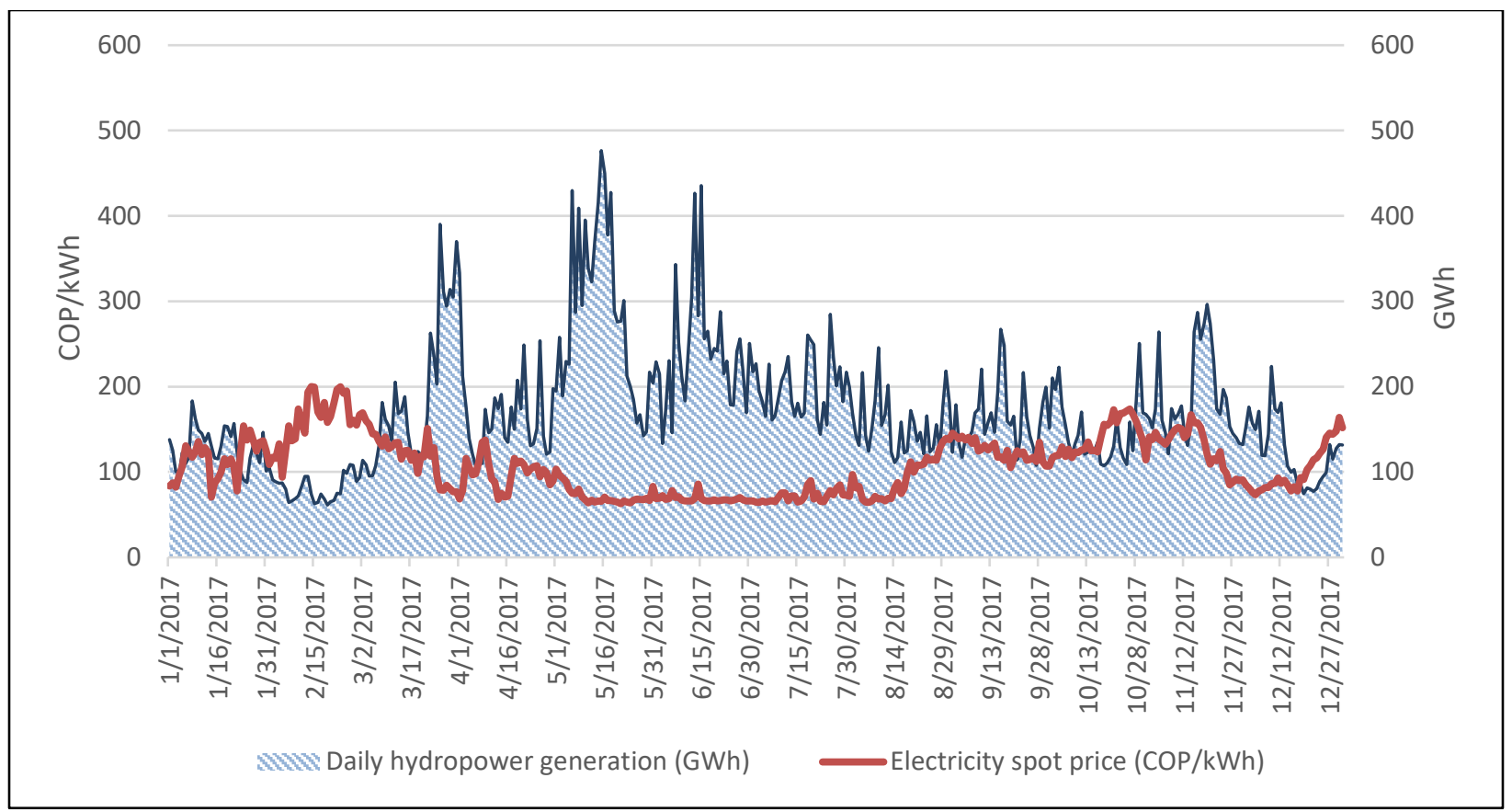

Source: XM (2019a)

Figure 63. Spot price and hydropower generation

La Niña events produce higher than normal precipitation in Colombia, which affects several sectors of the Colombian economy, such as agriculture. However, La Niña effects on electric system reliability are typically not severe.

Weather phenomena such as El Niño, growing electricity consumption, and Colombia's reliance on hydropower challenge the country's electric system reliability. The government projects an average 3\% annual growth in electricity demand for the period between 2017 and 2030 (International Renewable Energy Agency 2018). The government estimates that climate change will reduce hydropower production by $6 \%$ per MW of installed capacity by 2050 (Macías Parra and Andrade 2013), although other analyses provide different estimates depending on scenario assumptions (Arango-Arumbo et al. 2019, Guerra et al. 2019).

Droughts can disrupt power supply during the most intense El Niño events, but they also cause electricity price spikes in less severe years. The government is looking to increase the capacity of natural gas generators to increase the ability of the system to respond to drought conditions, and to increase the penetration of solar and wind to achieve the country's decarbonization goals. Increasing the amount of renewable energy generation in the system can also help Colombia reduce its consumption of natural gas, of which Colombia has recently become a net importer.

\subsubsection{Public Opposition to New, Large-Scale Hydropower Plants}

The country is also experiencing opposition to new, large hydropower projects. Ituango, a 2.4 $\mathrm{GW}$ dam and hydropower project is facing lawsuits and cost overruns due to construction problems in the order of $\$ 1$ billion. The government is considering stopping the development of this hydropower plant (Hydro Review 2019; International Renewable Energy Agency 2018). 


\subsection{Key Policy Options to Enhance Flexibility in Colombia}

\subsubsection{Electricity Sector Options}

Generation mix diversification: Colombia has been working to diversify its electricity matrix since the inception of the wholesale energy market and the reliability market in the mid-1990s. However, the country's dependence on hydropower remains at a similar level. Colombia's second - and this time successful — attempt for a renewable auction in October 2019 has ignited enthusiasm that VRE will play an increasingly important role in the future. Other than continuing with renewable energy auctions, the country could also reform its reliability market to compensate variable renewable energy for its ability to complement hydropower generation. Additionally, contracts for solar and wind could include a "green charge" to compensate those technologies for their environmental and emission reduction attributes.

Energy storage: As demonstrated by the electricity scarcity and market price volatility caused by droughts, Colombia has insufficient storage capacity in its embankment hydropower plants. Given the public opposition to new large hydropower construction, it may be difficult to expand current embankments. However, expanding water storage capacity could even out the constant fluctuations in hydropower output that the country experiences even in years with normal rainfall. However, storing water during dry years may stress other sectors, in particular the agricultural sector. Natural gas storage could also help the country during droughts if Colombia creates capacity to store excess natural gas during years where hydropower capacity is available at a high level.

Regional interconnections: Existing electric interconnections to Ecuador could be a source of flexibility. Ecuador is looking at expanding its power capacity with the explicit goal of exporting to Colombia. Ecuador is also highly reliant on hydropower, however. This could reduce Ecuador's capacity to export energy when Colombia needs it the most, which is during long El Niño events. The governments of Panama and Colombia are working on the standardization of regulations to interconnect the electricity systems of both countries. The Colombian government has announced that a competitive bidding process for a transmission line between the two countries could be launched in 2020 (Bnamericas 2019c). These links could increase the flexibility of both Colombia and the Central American region.

Demand side management: During the El Niño event of 2016, the Colombian government implemented a two-month program to avoid electricity shortages and blackouts in which users that reduced their consumption were rewarded and users that increased their consumption were penalized. The program was successful in reducing demand by $1,179 \mathrm{GWh}$, roughly three times the original target (Rudnick and Velásquez 2019). The government could formalize regulations to implement this program. Even when the system is not experiencing scarcity, this program could reduce the use of natural gas.

Effective pricing mechanisms and reliability market: Reducing the country's dependence on hydropower could help stabilize prices in the spot market because high reliance on hydropower depresses prices when hydropower is available and produces price spikes when it is not available. Such volatility also creates uncertainty for developers of thermal power plants, and, even for Ecuador, if the country decides to export electricity to Colombia. The reliability market has proven ineffective in increasing the share of thermal power in the electricity matrix even 
after the reforms of 2006. Options include looking at the experience of successful capacity markets in other countries and reasonable compensation for solar and wind. The next renewable energy actions will be a test for the government's ability to increase the existing wind and solar capacity, which is one of the lowest for the major countries in South America.

\subsubsection{Natural Gas Sector Policy Options}

Investment in domestic production: Colombia has vast offshore gas reserves, which will take years to develop and reach consumers. The country will have to invest heavily and attract significant capital in order to spur offshore play development and to build the gas transportation infrastructure to reach the country's gas network.

New LNG ports: To bridge the growing gap between demand and domestic gas production, Colombia has commissioned one FSRU and is planning a second unit. Depending on the country's ability to develop its new gas plays on time, the government may need to commission a third LNG port. Paradoxically, droughts also affect the capacity of the Panama Canal to accept large ships. Since the United States is the closest large exporter of LNG, Colombia may want to consider new regasification capacity on the Atlantic coast to avoid potential constraints in the Panama Canal.

\section{Summary}

Colombia has been a leader in the region in the reform of its energy markets. However, the country still faces some important challenges, such as its heavy reliance on hydropower and the declining domestic production of natural gas. The country's natural gas and renewable energy potential could offer relief in the long term. In the short term, continuing with the strategy of importing LNG seems to be one of the most viable options. 


\section{References for Section 7}

Arango-Aramburo, Santiago; Turner, Sean W.D.; Daenzer, Katherine; Ríos-Ocampo, Juan Pablo;' Hejaz, Mohamad; Kober, Tom; Álvarez-Espinosa, Andrés; Romero-Otalora, Germán; van der Zwaan, Bob. 2019. "Climate Impacts on Hydropower in Colombia: A Multi-model Assessment of Power Sector Adaptation Pathways.” Energy Policy, Vol. 128, pp. 179-199; May.

Argus Media. 2018. "Ecuador Eyes Colombia's Power Market, LNG Imports." November 5. https://www.argusmedia.com/en/news/1786760-ecuador-eyes-colombias-power-market-lngimports.

Bnamericas. 2018. "Colombia May Need 3rd LNG Plant within a Decade.” BNamericas.Com. https://www.bnamericas.com/en/news/colombia-may-need-3rd-lng-plant-within-a-decade.

Bnamericas. 2019a. "Colombia Define Reglas de Nueva Subasta de Renovables." BNamericas.Com. https://www.bnamericas.com/es/noticias/colombia-define-reglas-de-nuevasubasta-de-renovables.

Bnamericas. 2019b. "Unidad de Planeación Minero Energética (UPME).” BNamericas.Com. https://www.bnamericas.com/en/company-profile/unidad-de-planeacion-minero-energeticaupme.

Bnamericas. 2019c. "Bnamericas - Colombia, Panama Readying Interconnection Call." Bnamericas.Com. https:/www.bnamericas.com/en/news/colombia-panama-readyinginterconnection-call.

BP. 2019. "Statistical Review of World Energy 2019." https://www.bp.com/content/dam/bp/business-sites/en/global/corporate/pdfs/energyeconomics/statistical-review/bp-stats-review-2019-full-report.pdf.

Cho, Renee. 2016. "El Niño and Global Warming-What's the Connection?" State of the Planet (blog). February 2. https://blogs.ei.columbia.edu/2016/02/02/el-nino-and-global-warming-whatsthe-connection/.

Cigüenza Riaño, Noelia. 2019. "Los subsidios a los servicios públicos dejaron un déficit de $\$ 2,5$ billones el año pasado.” https://www.larepublica.co/economia/los-subsidios-a-los-serviciospublicos-dejaron-un-deficit-de-25-billones-el-ano-pasado-2880267.

Clavijo, Sergio, Alejandro Vera, and Ekaterina Cuéllar. 2016. "La Crisis Energética de Colombia (2015-2016).” http://anif.co/sites/default/files/abr6-16.pdf.

Comisión de Regulación de Energía y Gas. 2019. “Gestor Del Mercado de

Gas.” http://www.creg.gov.co/sites/default/files/jul302019 cartilla_gestor_del_mercado_de_gas 1.pdf.

Comisión de Regulación de Energía y Gas. 2016. "Nueva Propuesta de Transporte de Gas Natural." CREG. November.

http://www.creg.gov.co/sites/default/files/nueva_propuesta_de transporte_de_gas_natural.pdf 
Comisión de Regulación de Energía y Gas. 2013a. "Estructura del Sector." CREG. October 23. http://www.creg.gov.co/sectores-que-regulamos/gas-natural/estructura-del-sector.

Comisión de Regulación de Energía y Gas. 2013b. "Historia en Colombia.” CREG. October 23. http://www.creg.gov.co/sectores-que-regulamos/gas-natural/historia-en-colombia.

Departamento Nacional de Planeación (DNP). 2017. "Balance de Resultados 2016, PND 20142016." https://www.cnp.gov.co/Documents/Foros\%20Regionales\%202017/Balance\%20de\%20R esultados $\% 202016 \% 20-\% 20$ Foro $\% 20$ Regi $\% C 3 \%$ B3n $\% 20$ Eje $\% 20$ Cafetero.pdf.

DISTASA. 2019. “About Us.” http://www.distasa.com/index.php/en/about-us.

Giraldo, Iván Mario, and David Robinson. 2016. "Balancing Decarbonization and Liberalization in the Power Sector: Lessons from Colombia." Oxford Energy Forum 104. https://www.oxfordenergy.org/wpcms/wp-content/uploads/2018/06/OEF-114.pdf.

Golden Gate Weather Services. 2019. "E1 Niño and La Niña Years and Intensities.” https://ggweather.com/enso/oni.htm.

Guerra, Omar J., Tejada, Diego A., and Reklaitis, Gintaras,V. 2019. "Climate Change Impacts and Adaptation Strategies for a Hydro-dominated Power System via Stochastic Optimization," Applied Energy, Volumes 233-234, pp. 584-598, January.

Harindranath, Arjun. 2018. "How Will El Niño Affect Colombia?” The Bogotá Post (blog). October 1. https://thebogotapost.com/how-will-el-nino-affect-colombia/32389/.

HSBC Global Research. 2018. "Fragile Planet--Scoring Climate Risks Around the World." https://www.sustainablefinance.hsbc.com/-/media/gbm/reports/sustainable-financing/fragileplanet.pdf.

Hydro Review. 2019. "Cost Overruns on 2.4-GW Ituango Hydro Project in Colombia Could Exceed US\$1 Billion.” https://www.hydroworld.com/articles/2019/07/cost-overruns-on-2-4-gwituango-hydro-project-in-colombia-could-exceed-us-1-billion.html.

International Energy Agency. 2019. "Statistics.” Accessed November 2019. https://www.iea.org/statistics/?country $=$ COLOMBIA\&year $=2016 \&$ category $=$ Key $\% 20$ indicators $\underline{\text { \&indicator }=\text { HydroGen } \& \text { mode }=\text { chart } \& \text { categoryBrowse }=\text { false } \& \text { dataTable }=\text { ELECTRICITYAND }}$ $\underline{\text { HEAT \&showDataTable }=\text { true }}$

Interconexión Eléctrica S.A. E.S.P ISA. 2019. “Our Company.” http://www.isa.co/en/ourcompany/Pages/default.aspx.

International Gas Union. 2019. “2019 World LNG Report.”

International Hydropower Association. 2018. "Colombia.” https://www.hydropower.org/countryprofiles/colombia. 
International Renewable Energy Agency. 2018. "Colombia Power System Flexibility Assessment." https://irena.org//media/Files/IRENA/Agency/Publication/2018/Nov/IRENA_Columbia_FlexTool_2018.pdf.

Macías Parra, Ana María, and Jaime Andrade. 2013. “Estudio de Generación Eléctrica Bajo Escenario de Cambio Climatico."

http://www1.upme.gov.co/Documents/generacion_electrica_bajo_escenarios_cambio_climatico. pdf.

McRae, Shaun D., and Frank A. Wolak. 2019. "Market Power and Incentive-Based Capacitypayment Mechanisms." https://web.stanford.edu/group/fwolak/cgibin/sites/default/files/2019-03-mcrae-wolak-capacity.pdf.

Ministerio de Minas y Energía. 2018. "Circular Externa Para Prestadores Del Servicio Público Domiciliario de Energía Eléctrica y Gas, Aplicación Artículo 104 de La Ley 1873 de 2017."

Natural Gas News. 2019. "Country Focus: Colombia: A Small and Uncertain Market for LNG [LNG Condensed]." https://www.naturalgasworld.com/country-focus-colombia-a-small-anduncertain-market-for-lng-lng-condensed-70100.

Newbery, Emma. 2019. "What Is Going on with Fracking in Colombia?” The Bogotá Post (blog). June 6. https://thebogotapost.com/what-is-going-on-with-fracking-in-colombia/38616/.

Nieves Zárate, Margarita Teresa, and Augusto Hernández Vidal. 2016. “Colombia Energy Investment Report."

Organisation for Economic Co-operation and Development. 2015. "OECD Review of the Corporate Governance of State-Owned Enterprises: Colombia." http://www.oecd.org/daf/ca/Colombia_SOE_Review.pdf.

Portafolio. 2019. "Las Importaciones de Gas Natural Se Duplicarán Este Año." https://www.portafolio.co/economia/las-importaciones-de-gas-natural-se-duplicaran-este-ano$\underline{528564}$.

Ramirez, Miguel. 2018. "A Natural Gas Revolution in Colombia." http://www.searchanddiscovery.com/pdfz/documents/2018/70323ramirez/ndx_ramirez.pdf.html.

Renewables Now. 2019. "Colombian Renewables Auction Closes with 1298 MW of Wind, Solar.” 23 October. https://renewablesnow.com/news/colombian-renewables-auction-closeswith-1298-mw-of-wind-solar-673555/

Rudnick, Hugh, and Constantin Velásquez. 2019. "Learning from Developing Country Power Market Experiences, The Case of Colombia."

http://documents.worldbank.org/curated/en/898231552316685139/Learning-from-DevelopingCountry-Power-Market-Experiences-The-Case-of-Colombia. 
Sbroiavacca, Nicolás Di, Hilda Dubrovsky, Gustavo Nadal, and Rubén Contreras Lisperguer. 2019. "Rol y Perspectivas Del Gas Natural En La Transformación Energética de América Latina.” https://repositorio.cepal.org/bitstream/handle/11362/44596/1/S1801057 es.pdf.

Semana. 2007. “Apagón en toda Colombia.” Apagón en toda Colombia.

https://www.semana.com/on-line/articulo/apagon-toda-colombia/84946-3.

SIPA Center on Global Energy Policy. 2019. The Outlook for Colombia's Energy Sector. https://energypolicy.columbia.edu/outlook-colombias-energy-sector.

Sistema de Información Eléctrico Colombiano (SIEL). 2019. "Consultas Estadísticas de Generación.” http://www.siel.gov.co/Inicio/Generaci\%C3\%B3n/Generaci\%C3\%B3n1/tabid/143 $\underline{\text { Default.aspx }}$

Stout, Sherry. 2019. Personal communication on 16 October. National Renewable Energy Laboratory.

Symmes Cobb, Julia. 2019a. "Colombia Gets Bids from 27 Companies in Renewable Energy Tender:..." Reuters, February 1. https://www.reuters.com/article/us-colombia-energyidUSKCN1PQ5MD.

Symmes Cobb, Julia. 2019b. "Four Colombia Fracking Projects Could Bring \$5 Billion in Annual Investment." Reuters, September 24. https://www.reuters.com/article/us-colombiafracking-idUSKBN1W92AN.

Symmes Cobb, Julia, and Luis Acosta. 2019. "Fracking Could Nearly Triple Colombia Oil and Gas Reserves: Minister." Reuters, March 8. https://www.reuters.com/article/us-colombia-energyidUSKCN1QP1OO.

Unidad de Planeación Minero Energética (UPME). 2014. "Plan de Expansión de Referencia Generación-Transmisión 2015-2029." http://www1.upme.gov.co/Energia electrica/Planesexpansion/Plan-Expansion-2015-2029/Plan_GT 2015-2029 VF_22-12-2015.pdf.

Unidad de Planeación Minero Energética. 2017. "Boletín Estadístico de Minas y Energía 20122016." http://www.simec.gov.co/Inicio/Comit\%C3\%A9s/tabid/63/Default.aspx.

Unidad de Planeación Minero Energética. 2018. "Informe Mensual De Variables De Generación y Del Mercado Eléctrico Colombiano."

http://www.siel.gov.co/portals/0/generacion/2018/Informe_de_variables_Ago_2018.pdf.

Unidad de Planeación Minero Energética. nd. "Colombian Electric Power System: New Projects, Latest Investmernt Opportunities.” https://www.usea.org/sites/default/files/event/UPME_Colombia_New Projects.pdf

Unidad de Planeación Minero Energética. 2013. "Boletín Estadístico de Minas y Energía 20082012.” http://www.simec.gov.co/Inicio/Comit\%C3\%A9s/tabid/63/Default.aspx. 
Unidad de Planeación Minero Energética. 2014. "Plan de Expansión de Referencia GeneraciónTransmisión 2014-2028."

http://www.simec.gov.co/Inicio/Comit\%C3\%A9s/tabid/63/Default.aspx.

Unidad de Planeación Minero Energética. 2018a. "Balance Energético Colombiano - BECO.”

Unidad de Planeación Minero Energética. 2018b. "Boletín Estadístico de Minas y Energía

2018." http://www.simec.gov.co/Inicio/Comit\%C3\%A9s/tabid/63/Default.aspx.

Unidad de Planeación Minero Energética. 2019. "Informe Mensual De Variables De Generación y Del Mercado Eléctrico Colombiano."

http://www.siel.gov.co/portals/0/generacion/2018/Informe de variables_Ago_2018.pdf.

U.S. EIA. 2019. "Background Reference: Colombia." 2019.

https://www.eia.gov/beta/international/analysis_includes/countries_long/Colombia/background.h tm.

XM. 2018. "Informe de Operación Del SIN y Administración Del Mercado 2017." http://informesanuales.xm.com.co/2017/SitePages/operacion/Default.aspx.

2019a. "Informe de Operación Del SIN y Administración Del Mercado.” 2019.

http://informesanuales.xm.com.co/2014/SitePages/operacion/1-4-Agentes-del-mercado.aspx.

.2019b. "Informes Mensuales de Análisis del Mercado."

https://www.xm.com.co/Paginas/Informes.aspx 


\section{Synthesis and Conclusions}

Providing affordable, sustainable, reliable, flexible, and resilient power to end-users are increasingly important objectives for countries around the world. In South America, meeting these goals is further challenged by two factors: 1) the apparently growing variability of hydropower output associated with both El Niño and La Niña hydrological patterns, and 2) rapid growth in variable renewable energy output, mainly wind and solar, which is not "dispatchable" in the same way as thermal generators. How to supply power most economically during periods of low hydropower output - and over shorter periods when VRE might not be available - is a critical challenge for many countries in South America.

\subsection{Comparing and Contrasting Challenges}

This study presented some options for Argentina, Brazil, Chile and Colombia to determine how their objectives might best be met. Table 10 compares and contrasts risks and constraints associated with achieving greater flexibility in power generation for all four countries. Brazil and Colombia are most exposed to threats from El Niño and La Niña impacts on hydropower output. Brazil and Chile are experiencing the fastest growth in VRE deployment. Currently, Argentina is most exposed to risk from fuel supply uncertainty, although Brazil, Chile and Colombia are not immune to these risks. All countries except Brazil face challenges in extracting greater flexibility from their existing thermal fleet of generators. Argentina probably has the best chance of continuing to build large hydropower plants, but even there, public opposition to that choice is still high.

Table 10. Risks and Constraints for More Flexible Power Generation in Select South American Countries

\begin{tabular}{|l|l|c|c|c|c|}
\cline { 3 - 5 } \multicolumn{1}{l|}{} & Argentina & Brazil & Chile & Colombia \\
\hline \multirow{4}{*}{$\begin{array}{l}\text { Flexibility } \\
\text { Catalysts }\end{array}$} & Weather events affecting hydropower & Medium & High & Medium & High \\
\cline { 2 - 6 } & $\begin{array}{l}\text { Increasing adoption of run-of-the-river } \\
\text { power plants }\end{array}$ & Medium & High & Medium-High & High \\
\cline { 2 - 6 } & Increasing VRE integration & Medium & High & High & Low \\
\cline { 2 - 6 } & Thermal power generation inflexibility & High & Low & High & High \\
\cline { 2 - 6 } & Fuel-supply uncertainties & High & Medium & Medium & Medium \\
\hline
\end{tabular}

Table 11 summarizes some of the key barriers and challenges to further development of the electricity and natural gas sectors in the four countries targeted in this study. Relative to the others, Argentina faces challenges due to aging infrastructure (exemplified by the blackout in June of 2019) and in directing sufficient revenue for investment in both electricity and gas; a situation that is mainly due to its prolonged economic instabilities (high inflation rates and currency fluctuation) and market distortions associated with subsidies. All four countries face limitations associated with transmission capacity, public opposition to large hydropower plants and market mechanisms to promote greater flexibility in the electricity sector. In the gas sector, all four countries face limitations in underground storage and pipeline capacity. Chile is relatively unique in being the only country with insufficient domestic gas reserves, while Brazil faces techno-economic challenges associated with developing the offshore Pre-Salt resources. 
Table 11. Barriers and Challenges for Electricity and Natural Gas Development in Select South American Countries

\begin{tabular}{|c|c|c|c|c|c|}
\hline & Issue & Argentina & Brazil & Chile & Colombia \\
\hline \multirow{7}{*}{$\begin{array}{l}\text { Relative } \\
\text { barriers } \\
\text { and } \\
\text { challenges } \\
\text { in the } \\
\text { electricity } \\
\text { sector }\end{array}$} & Aging infrastructure & $\mathrm{x}$ & & & \\
\hline & Transmission capacity limitations & $\mathrm{x}$ & $\mathrm{x}$ & $\mathrm{x}$ & $x$ \\
\hline & Insufficient revenue for investment & $\mathrm{x}$ & & & \\
\hline & Public opposition to hydropower plants & $x$ & $\mathrm{x}$ & $x$ & $x$ \\
\hline & Limited international interconnections & & & $\mathrm{x}$ & $\mathrm{x}$ \\
\hline & $\begin{array}{l}\text { Lack of market mechanisms to promote greater } \\
\text { flexibility }\end{array}$ & $x$ & $\mathrm{x}$ & $x$ & $x$ \\
\hline & Demand concentration in specific regions & $x$ & & $\mathrm{x}$ & \\
\hline \multirow{5}{*}{$\begin{array}{l}\text { Relative } \\
\text { barriers } \\
\text { and } \\
\text { challenges } \\
\text { in the } \\
\text { natural } \\
\text { gas sector }\end{array}$} & $\begin{array}{l}\text { Techno-economic challenges associated with } \\
\text { domestic production }\end{array}$ & & $x$ & & \\
\hline & Insufficient long-term domestic gas reserves & & & $x$ & \\
\hline & Lack of underground storage infrastructure & $\mathrm{x}$ & $\mathrm{x}$ & $\mathrm{x}$ & $\mathrm{x}$ \\
\hline & Pipeline capacity limitations & $\mathrm{x}$ & $x$ & $x$ & $\mathrm{x}$ \\
\hline & Insufficient revenue for investment & $\mathrm{x}$ & & & \\
\hline
\end{tabular}

\subsection{Country-Specific Options}

\subsubsection{Argentina}

The Argentinian energy sector currently faces strong headwinds due to the shrinking economy, high inflation, and the depreciating peso. Nonetheless, Argentina has very ambitious efforts to develop the Vaca Muerta formation and build infrastructure to move gas to market. This play has the potential to not only supply Argentina's domestic needs, but it could - under ideal conditions - allow Argentina to export gas by pipeline to Chile, Brazil and potentially others, and ship it in the form of LNG to other countries. Development of the resource, and the infrastructure needed to move the gas considerable distances, is challenged by the current economic difficulties and decades of market distortions that impact the flow of investments. While the Macri government has taken steps to reduce these distortions, economic uncertainty remains, and new political developments could reverse gains made over the past few years. Addressing remaining market distortions so that investment will flow to where it is most needed is a key challenge for Argentinian policymakers, although this is very difficult in a period of economic crisis.

Adding more natural gas pipelines and underground storage appears to be a high priority for the country given the seasonal imbalances in the market.

Over the past few years, Argentina has taken successful steps to accelerate the deployment of renewables through its auction programs. Continued focus on deploying VRE can be a source of low-cost electricity that offsets the need for gas- or oil-fired generation, although siting and constructing new transmission lines would likely be challenging. Demand side energy efficiency activities may be one of the least costly ways for Argentina to ensure reliable electricity services, especially given the demand growth that occurred during the peak years of energy subsidies. 
Coordinated planning of energy infrastructure using state-of-the-art modeling tools remains an important task for Argentinian decision-makers.

\subsubsection{Brazil}

Brazil's power sector continues to be dominated by hydropower, although its share of total generation has been in decline since roughly 2011. Brazil has sophisticated energy planning and operations capability and has installed more renewables than any other South American country over the past decade. It is working to integrate more VRE and demand-response capabilities into the grid, and reforming electricity pricing mechanisms to better reflect supply and demand over shorter time intervals. It may also benefit from greater interconnection of transmission lines with neighboring countries and greater integration of DERs.

Brazil is working to develop its considerable offshore natural gas resources, and like Argentina, would benefit from more gas infrastructure, especially large-scale underground storage. It has taken advantage of FSRU units to import LNG during periods of peak demand without having to commit to permanent onshore infrastructure. This reliance on FSRUs is expected to grow over the coming years, at least until more certainty over development of offshore resources is revealed. It is also taking steps to introduce more competition within the natural gas sector and reduce the dominance of Petrobras in this sector.

\subsubsection{Chile}

Chile has been at the global forefront in introducing market-oriented liberalization and privatization in its energy sector. Chile faced a gas crisis starting in 2004 (when Argentina abruptly reduced pipeline exports) that had profound impacts on the country. The immediate response was to briefly rely on petroleum products in electricity generation to make up for the lost gas supply and to construct several LNG import terminals. Coal generation also grew rapidly over the past decade as a longer-term substitute for natural gas, but the government announced in mid-2019 that it would phase out coal generation by 2040 .

Chile has also seen rapid growth in VRE since 2014 and has extremely high-quality solar resources in the north and wind resources in the south. Planning and constructing transmission capacity to move the power to the demand centers in and around Santiago (and to mining load centers in the northern regions for night-time operations) remains a top priority for Chilean decision-makers. The share of electricity coming from hydropower plants with large reservoirs has fallen rapidly as the country moved to greater reliance on run-of-the-river configurations, which are not capable of providing medium- and long-term flexibility services.

Chile is likely to rely more heavily on imported natural gas in the near term given the shrinking availability of hydropower and the planned phase-out of coal. It has plans to build new LNG import infrastructure and recently began to import gas again from Argentina via pipeline. Greater interconnection of electricity lines with neighboring countries, use of demand response, deployment of a variety of energy storage options are three other opportunities for Chile to improve flexibility and resilience in the power sector. 


\subsubsection{Colombia}

Like much of Brazil, Colombia is heavily dependent on large hydropower and is exposed to drought conditions during El Niño years. Colombia is a major exporter of coal, yet that fuel supplies only about 10 percent of the electricity generation mix, on par with natural gas generation. The country's natural gas production is in fairly rapid decline, while demand continues to grow, leading Colombia to begin importing LNG in 2017 using FSRUs. LNG imports are expected to grow rapidly in the near future. A pipeline connects Venezuela and Colombia, but no trade occurs despite the former having the largest gas reserves in South America. Both countries use the majority of their natural gas for reinjection at oil production sites to increase formation pressure. Also, like Brazil, Colombia has recently discovered significant offshore gas reserves, but analysts do not expect growth in production for a least a decade when drilling and infrastructure build-out can be completed.

Colombia has a partially liberalized electricity sector but still provides subsidies to non-lowincome consumers. It is beginning to rectify the distortions that these subsidies can cause. Colombia is the only country analyzed here that does not yet have a developed market for VRE deployment, although the country's first successful VRE auction of late 2019 is likely to improve the situation. Colombia is targeting over 2,000 MW of new renewables to be deployed by the end of 2020 (Renewables Now 2019).

\subsection{Opportunities for International Collaboration}

In addition to the country-specific policy choices that each jurisdiction faces, the international community can offer a variety of bi- and multi-lateral assistance and cooperation to further enhance flexibility and resilience in South American electricity markets.

The Inter-American Development Bank and other multilateral organizations have supported regional studies in South America that evaluate the impact of greater cross-border electricity trade (UNDP 2009, IDB 2016, IDB 2017)). There are complex technical and market design challenges that must be overcome to enable such cross-border trade, but grid integration studies can provide powerful insights to electricity system planners and policymakers on the most beneficial actions to take in order to address power sector goals. Greater cross-border trade in electricity can help better balance supply and demand, reduce peak loads, and integrate sources of variable renewable energy.

Supporting capacity building efforts to enable the use of advanced tools and data gathering techniques is another activity that can help some countries in South America. Some are still relying on outdated models to plan and operate their power systems. Argentina, for example, could benefit from using more advanced models to simulate the coordinated build-out of its natural gas and electricity sectors, prioritize infrastructure investment needs, and understand key tradeoffs related to reliable and resilient power system options. The International Renewable Energy Agency (IRENA), for example, has applied its FlexTool to assess flexibility options in Colombia on a granular basis and determined that the grid would not face flexibility challenges by 2030 after achieving its targeted renewable energy goals (IRENA 2018). Likewise, recent examples of grid integration studies in India and the Philippines found that these countries could operate their grids reliably after reaching ambitious clean energy targets (USAID 2017, USAID 
2018). Stakeholders in South America could conduct similar studies to inspire confidence in future integrated clean energy plans and further raise ambition.

\subsection{Conclusion}

Argentina, Brazil, Chile and Colombia face unique challenges in building out their electricity sectors to achieve resilient, reliable, and sustainable electricity systems. Each country faces challenges from uncertain hydropower output, but Argentina is less exposed to these variations. All have goals to rapidly boost domestic VRE generation, and all except Chile have significant natural gas resources that they plan to aggressively develop. Argentina's Vaca Muerta formation may be the biggest uncertainty in all of South America's evolving electric power sector calculus: this promising resource base could have global repercussions on energy markets, yet the country faces significant economic and political challenges in developing it. In the meantime, imported LNG may be the most expedient option for Brazil, Chile and Colombia on the margins given the recently improved liquidity of, and contract terms for, that fuel.

While technology and market innovations in the form of rapidly falling costs for VRE, LNG contracting, battery storage, and other distributed energy options are sometimes outpacing the institutional and policy capacity to effectively guide them, other breakthroughs could occur to better harmonize the deployment of flexibility and resiliency options. These South American countries face significant challenges in meeting future electricity sector goals, but the speed of change is occurring so rapidly that unexpected developments should be considered likely. On a positive note, they are each building from a strong base of renewable hydropower toward a diverse portfolio of solar, wind, and gas, targeting clean and resilient power systems. 


\section{References for Section 8}

Inter-American Development Bank (IDB). 2016. "Arco Norte: Electrical Interconnection Study." July. IDB. https://publications.iadb.org/publications/english/document/Arco-Norte-Electrical$\underline{\text { Interconnection-Study.pdf }}$

Inter-American Development Bank (IDB). 2017. "La Red del Futuro: Desarrollo de Una Red Eléctrica Limpia y Sostenible para América Latina.” IDB. December.

https://publications.iadb.org/publications/spanish/document/La-Red-del-Futuro-Desarrollo-deuna-red-eléctrica-limpia-y-sostenible-para-América-Latina.pdf

International Renewable Energy Agency (IRENA). 2018. "Colombia Power System Flexibility Assessment: IRENA Flextool Case Study.” IRENA. October.

https://www.irena.org/publications/2018/Nov/Colombia-power-system-flexibility-assessment

United Nations Development Programme (UNDP). 2009. "Estudio Para Análisis de Prefactibilidad Técnico Económica de Interconexión Eléctrica entre Bolivia, Chile, Colombia, Ecuador y Peru." November, UNDP.

https://info.undp.org/docs/pdc/Documents/CHL/Resumen $\% 20$ Ejecutivo $\% 20$ Informe $\% 20$ Final $\%$ 20PNUD\%20DEF.pdf

United States Agency for International Development (USAID). 2017. "Greening the Grid: Pathways to Integrate $175 \mathrm{GW}$ of Renewable Energy into India's Electrical Grid." USAID and India's Ministry of Power. https://www.nrel.gov/docs/fy17osti/68530.pdf

USAID 2018. "Greening the Grid: Solar and Wind Grid Integration Study for the Luzon-Visayas System of the Philippines." USAID and Philippine's Department of Energy. https://www.nrel.gov/docs/fy18osti/68594.pdf 